UNITED STATES DEPARTMENT OF THE INTERIOR

GEOLOGICAL SURVEY

\title{
Analytical results and sample locality map \\ of stream-sediment and heavy-mineral-concentrate \\ samples from the Healy quadrangle, Alaska
}

By

R. M. O'Leary, J. D. Hoffman,

S. J. Sutley, and H. D. King

Open-File Report 84-104

This report is preliminary and has not been reviewed for conformity with U.S. Geological Survey editorial standards and stratigraphic nomenclature. Any use of trade names is for descriptive purposes only and does not imply endor sement by the USGS. 


\section{CONTENTS}

Studies related to AMRAP................................... 1

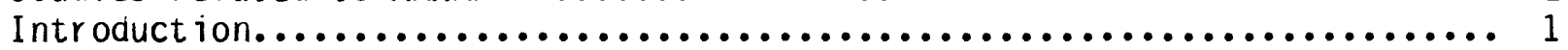

Methods of study......................................... 2

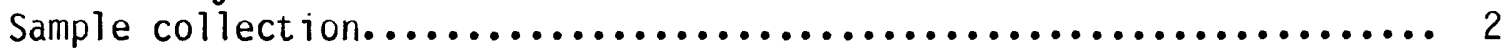

Stream-sediment samples............................... 2

Heavy-mineral-concentrate samples....................... 2

Sample preparation..................................... 3

Sample analysis........................................... 4

Spectrographic method.............................. 4

Chemical methods................................... 6

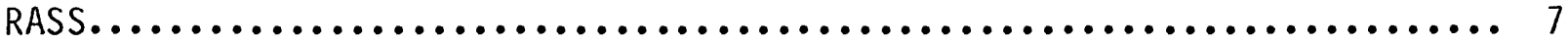

References cited.......................................... 7

TABLES

TABLE 1. Limits of determination for spectrographic analysis of heavy-mineral concentrates based on a 5-mg sample; and stream sediments based on a 10-mg sample.......... 5

TABLE 2. Chemical methods used............................. 6

TABLE 3. Spectrographic and chemical analyses of stream-sediment samples from the Healy quadrangle, Alaska............ 8

TABLE 4. Spectrographic analyses of heavy-mineral-concentrate samples from the Healy quadrangle, Alaska............ 80

\section{ILLUSTRATIONS}

PLATE 1. Map showing sites at which stream sediments and heavy-mineral-concentrate samples were collected from the Healy quadrangle, Alaska .............. In pocket 


\section{STUDIES RELATED TO AMRAP}

The U.S. Geological Survey, is required by the Alaskan National Interest Lands Conservation Act (ANILCA, Public Law 96-487) to survey certain Federal lands to determine their mineral resource potential. Results from the Alaskan Mineral Resource Appraisal Program (AMRAP) must be made available to the public and be submitted to the President and the Congress. This report presents analytical results of a geochemical survey of the Healy quadrangle, Alaska.

\section{INTRODUCTION}

In 1980, 1981, and 1982 we conducted a reconnaissance geochemical survey of the Healy quadrangle, Alaska.

The Healy quadrangle which comprises about $6720 \mathrm{Mi}^{2}\left(17,200 \mathrm{~km}^{2}\right)$ lies about $60 \mathrm{mi}(90 \mathrm{~km})$ south of Fairbanks, Alaska, and is transversed by the Alaska range. Access to the vicinity of the study area is provided on the north and south by the George Parks highway, on the east by the Denali highway. Access in the Healy quadrangle was provided by helicopter with the exception of a few sites that were accessible by road vehicle from the George Parks and Denali highways.

The geology of the Healy quadrangle includes 13 tectonostratigraphic terranes as outlined and described by Jones and others (1981), each terrane having distrinctive stratigraphic sequences or rock assemblanges. Cretaceous and/or Tertiary granitic rocks have intruded rocks of the various terranes; exposures are chiefly in the eastern and southern three fourths of the quadrangle. Several major faults transect the quadrangle including the McKinley and Hines Creek strands of the Denali fault, and the Talkeetna thrust fault. A geologic map of the Healy quadrangle at $1: 250,000$ scale is in preparation by Bela Csejtey, Jr. and others. The Healy quadrangle is included in a preliminary geologic map of the southeast quadrant of Alaska at $1: 1,000,000$ (Beikman, 1974). Geology of parts of the Healy quadrangle are contained in a number of reports. A few selected references are as follows: Csejtey, Jr. and others (1978); Hawley and Clark (1974); Smith (1981); Wahrhaftig (1970a, b, c, d).

The average topographic relief in the study area is about $3000 \mathrm{ft}$ $(915 \mathrm{~m})$, with a maximum elevation of $12,540 \mathrm{ft}(3825 \mathrm{~m})$. 


\section{METHODS OF STUDY}

\section{Sample Collection}

We collected samples at 1066 sites (plate 1). At nearly all of those sites, we collected both a stream-sediment sample and a heavy-mineral concentrate. We analyzed 1064 stream-sediment samples and 1045 panned-concentrate samples, for a sampling density of about 1 sample site per $6 \mathrm{mi}^{2}$ for the stream sediment and heavy-mineral concentrate. The drainage basins sampled ranged from 3 to $6 \mathrm{mi}^{2}$.

\section{Stream-sediment samples}

Analyses of the stream-sediment samples represent the chemistry of the rock material eroded from the drainage basin upstream from each sample site. Such information is useful in identifying those basins which contain concentrations of elements that may be related to mineral deposits.

The stream-sediment samples consisted of active alluvium collected primarily from first-order (unbranched) and second-order (below the junction of two first-order) streams as shown on USGS topographic maps $($ scale $=1: 63,360)$.

Where stream sediments were not available due to glacial ice cover in the drainage basin, a glacial-debris sample was collected. The sample consists of detrital material that has been mechanically introduced into a moraine from the bedrock and colluvium. Like the stream sediment, the glacial debris represents the chemistry of the rock material eroded from the drainage basin

Glacial-debris samples and heavy-mineral concentrates of glacial-debris samples were collected at the following sites: 143-150, 156-157, 217-233, 488-490, 704-705, and 748-750.

\section{Heavy-mineral-concentrate samples}

We panned heavy-mineral-concentrate samples from the same active alluvium as the stream-sediment samples. Each bulk sample was passed through a 2.0-mm (10-mesh) screen to remove the coarse material. The sediment passing through the screen was panned until most of the quartz, feldspar, organic material, and clay-sized material was removed. The sample was oven dried at $16^{\circ} \mathrm{C}$. 


\section{Sample Preparation}

We sieved the stream-sediment samples at the collection site through a 10-mesh screen and the minus-10-mesh material was retained. The samples were oven dried and sieved at 80 -mesh $(.18 \mathrm{~mm})$ using stainless steel sieves. The portion of the sediment passing through the sieve was saved for analysis.

The heavy-mineral-concentrate samples were preliminarily prepared in the field by panning the minus-10-mesh fraction of the stream sediment to remove the bulk of the light minerals. The panned samples were sieved through a 35-mesh (0.42-mm) screen in the laboratory and the minus-35-mesh fraction was further separated with bromoform (specific gravity 2.86) to remove the remaining light minerals. The heavy minerals were separated into three fractions using a large electromagnet (in this case a modified Frantz Isodynamic Separator). The most magnetic material (largely magnetite) was discarded. The second fraction (largely ferromagnesian silicates and ir on oxides) was saved for archival storage. The third fraction (the least magnetic material including nonmagnetic ore minerals, zircon, sphene, etc.) was divided into two splits using a Jones splitter. One split was hand ground for spectrographic analysis; the other split was saved for mineralogical analysis.

The magnetic separates discussed are the same separates that would be produced by removing the magnetite with a hand magnet and then using a Frantz I sodynamic Separator set at a slope of $15^{\circ}$ and a tilt of $10^{\circ}$ with a current of 0.1 ampere to remove the ilmenite, and a current of 0.6 ampere to split the remainder of the sample into magnetic and nonmagnetic fractions. 


\section{Sample Analysis}

\section{Spectrogr aphic method}

We analyzed the stream-sediment and heavy-mineral-concentrate samples for 31 elements using a semiquantitative, direct-current arc emission spectrographic method (Grimes and Marranzino, 1968). The elements analyzed and their lower limits of determination are listed in table 1. Spectrographic results were obtained by visual comparison of spectra derived from the sample against spectra obtained from standards made from pure oxides and carbonates. Standard concentrations are geometrically spaced over any given order of magnitude of concentration as follows: 100,50,20, 10, and so forth. Samples whose concentrations are estimated to fall between those values are assigned values of $70,30,15$, and so forth. The precision of the analytical method is approximately plus or minus one reporting unit at the 83 percent confidence level and plus or minus two reporting units at the 96 percent confidence level (Motooka and Grimes, 1976). Values determined for the major elements (iron, magnesium, calcium, and titanium) are given in weight percent; all others are given in parts per million (micrograms/gram). Analytical data for samples from the Healy quadrangle are listed in tables 3 and 4.

The spectrographic analyses were done by D. A. Risoli, J. A. Domenico, G. W. Day, S. J. Sutley, and E. F. Cooley. 
TABLE 1.--Limits of determination for the spectrographic analysis of heavy-mineral concentrates, based on a 5-mg sample; and stream sediments, based on a 10-mg sample

[The spectrographic limits of determination for heavy-mineral-concentrate samples are two reporting units higher than the limits given below for rocks and stream sediments]

Elements Lower determination limit Upper determination limit

Percent

\begin{tabular}{lcc}
\hline Iron (Fe) & 0.05 & 20 \\
Magnesium (Mg) & .02 & 10 \\
Calcium (Ca) & .05 & 20 \\
Titanium (Ti) & .002 & 1 \\
\hline
\end{tabular}

Parts per million

\begin{tabular}{|c|c|c|}
\hline Manganese $(M n)$ & 10 & 5,000 \\
\hline Silver $(\mathrm{Ag})$ & 0.5 & 5,000 \\
\hline Arsenic (Ás) & 200 & 10,000 \\
\hline Gold $(A u)$ & 10 & 500 \\
\hline Bor on $(B)$ & 10 & 2,000 \\
\hline Barium (Ba) & 20 & 5,000 \\
\hline Beryllium (Be) & 1 & 1,000 \\
\hline Bismuth (Bi) & 10 & 1,000 \\
\hline Cadmi um (Cd) & 20 & 500 \\
\hline Cobalt (Co) & 5 & 2,000 \\
\hline Chromium (Cr) & 10 & 5,000 \\
\hline Copper (Cu) & 5 & 20,000 \\
\hline Lanthanum (La) & 20 & 1,000 \\
\hline Molybdenum (Mo) & 5 & 2,000 \\
\hline Niobium (Nb) & 20 & 2,000 \\
\hline Nickel (Ni) & 5 & 5,000 \\
\hline Lead (Pb) & 10 & 20,000 \\
\hline Ant imony (Sb) & 100 & 10,000 \\
\hline Scandium (Sc) & 5 & 100 \\
\hline $\operatorname{Tin}(S n)$ & 10 & 1,000 \\
\hline Strontium (Sr) & 100 & 5,000 \\
\hline Vanadium (V) & 10 & 10,000 \\
\hline Tungsten (W) & 50 & 10,000 \\
\hline Yttrium (Y) & 10 & 2,000 \\
\hline $\operatorname{Zinc}(\mathrm{Zn})$ & 200 & 10,000 \\
\hline Zirconium $(\mathrm{Zr})$ & 10 & 1,000 \\
\hline Thorium (Th) & 100 & 2,000 \\
\hline
\end{tabular}




\section{Chemical methods}

Other methods of analysis used on samples from the Healy quadrangle are summarized in table 2 .

\section{Table 2.--Chemical methods used}

\begin{tabular}{ccccc}
\hline $\begin{array}{c}\text { Sample } \\
\text { type }\end{array}$ & $\begin{array}{c}\text { Constituent } \\
\text { determined }\end{array}$ & $\begin{array}{c}\text { Analytical } \\
\text { method }\end{array}$ & $\begin{array}{c}\text { Determination } \\
\text { limit } \\
\text { micrograms/ } \\
\text { gram or ppm }\end{array}$ & Analyst
\end{tabular}

\begin{tabular}{|c|c|c|c|c|c|}
\hline \multirow[t]{5}{*}{ Sediments } & $\mathrm{Au}$ & AA & .05 & $\begin{array}{l}\text { R. O'Leary } \\
\text { J. Hoffman }\end{array}$ & $\begin{array}{l}\text { Thompson and } \\
\text { others, } 1968 .\end{array}$ \\
\hline & $\mathrm{Zn}$ & $A A$ & 5 & $\begin{array}{l}\text { A. Gruzensky } \\
\text { A. Meier }\end{array}$ & $\begin{array}{l}\text { Ward and others, } \\
1969 .\end{array}$ \\
\hline & $\mathrm{Sb}$ & $A A$ & 2 & $\begin{array}{l}\text { F. Takacs } \\
\text { D. Hopkins }\end{array}$ & $\begin{array}{c}\text { Modification of } \\
\text { Viets, } 1978 .\end{array}$ \\
\hline & As & $A A$ & 10 & $\begin{array}{l}\text { A. Mantei } \\
\text { W. Martin }\end{array}$ & $\begin{array}{l}\text { Modification of } \\
\quad \text { Viets, } 1978 .\end{array}$ \\
\hline & $\mathrm{Cd}$ & $A A$ & .1 & & $\begin{array}{c}\text { Modification of } \\
\text { Viets, } 1978 .\end{array}$ \\
\hline
\end{tabular}

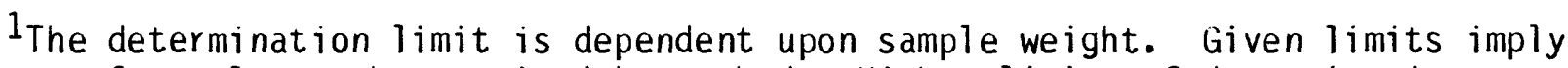
use of sample werght required by method. Higher limits of determination result from using less than required sample weight. 


\section{ROCK ANAYSIS STORAGE SYSTEM}

Upon completion of all analytical work, the analytical results were entered into a computer-based file called RASS (Rock Analys is Storage System). This RASS file contains both descriptive geological information and analytical data. Any or all of this information may be retrieved and converted to a standard form (STATPAC) for computerized statistical analysis or publication (VanTrump and Miesch, 1976).

\section{REFERENCES CITED}

Beikman, H. M., 1974, Preliminary geologic map of the southeast quadrant of Al aska: U.S. Geological Survey Miscellaneous Field Studies Map MF-612, 2 sheẹts, scale $1: 1,000,000$.

Csejtey, Bèla, Jr., Nelson, W. H., Jones, D. L., Silberling, N. J., Dean, R. M., Morris, M. S., Lanphere, M. A., Smith, J. G., and Silberman, M. L., 1978, Reconnaissance geologic map and geochronology, Talkeetna Mountains quadrangle, northern part of Anchorage quadrangle, and southwest corner of Healy quadrangle, Alaska: U.S. Geological Survey Open-File Report 78-558-A, 60 p.

Grimes, D. J., and Marranzino, A. P., 1968, Direct-current arc and alternating-current spark emission spectrographic field methods for the semiquantitative analysis of geologic materials: U.S. Geological Survey Circular 591, $6 \mathrm{p}$.

Hawley, C. C., and Clark, A. L., 1974, Geology and mineral deposits of the upper Chulitna district, Alaska: U.S. Geological Survey Professional Paper 758-B, $47 \mathrm{p}$.

Jones, D. L., Silberling, N. J., Berg, H. C., and Plafker, George, 1981, Map showing tectonostratigraphic terranes of Alaska, columnar sections, and summary description of terranes: U.S. Geological Survey Open-File Report $81-792$.

Motooka, J. M., and Grimes, D. J., 1976, Analytical precision of one-sixth order semiquantitative spectrographic analyses: U.S. Geological Survey Circular 738, $25 \mathrm{p}$.

Smith, T. E., 1981, Geology of the Clearwater Mountains, South-central Alaska: Alaska Division of Geological and Geophysical Surveys Geologic Report $60,72 \mathrm{p}$.

Thompson, C. E., Nakagawa, H. M., and Van Sickle, G. H., 1968, Rapid analysis for gold in geologic materials, in Geological Survey research 1968: U.S. Geological Survey Professional Paper 600-B, P. B130-B132.

VanTrump, George, Jr., and Miesch, A. T., 1976, The U.S. Geological Survey RASS-STATPAC system for management and statistical reduction of geochemical data: Computers and Geosciences, v. 3, p. 475-488.

Viets, J.G., 1978, Determination of silver, bismuth, cadmium, copper, lead, and zinc in geologic materials by atomic absorption spectrometry with tricaprylylmethylammonium chloride: Analytical Chemistry, v. 50, p. 1097-1101.

Wahrhaftiy, Clyde, 1970a, Geologic map of the Healy D-2 quadrangle, Alaska: U.S. Geological Survey Quadrangle Map GQ-804, 1 sheet, scale $1: 63,360$.

Wahrhaftig, Clyde, 1970b, Geologic map of the Healy D-3 quadrangle, Al aska: U.S. Geologic Survey Quadrangle Map GQ-805, 1 sheet, scale 1:63,360.

Wahrhaftig, Clyde, 1970C, Geologic map of the Healy D-4 quadrangle, Alaska: U.S. Geological Survey Quadrangle Map GQ-806, 1 sheet, scale $1: 63,360$.

Wahrhaftig, Clyde, 1970d, Geologic map of the Healy D-5 quadrangle, Al aska: U.S. Geological Survey Quadrangle Map GQ-807, 1 sheet, scale 1:63,360.

Ward, F. N., Nakayawa, H. M., Harms, T. F., and Van Sickle, G. H., 1969, Atomic-absorption methods useful in geochemical exploration: U.S. Geoloyical Survey Bulletin 1289, $45 \mathrm{p}$. 


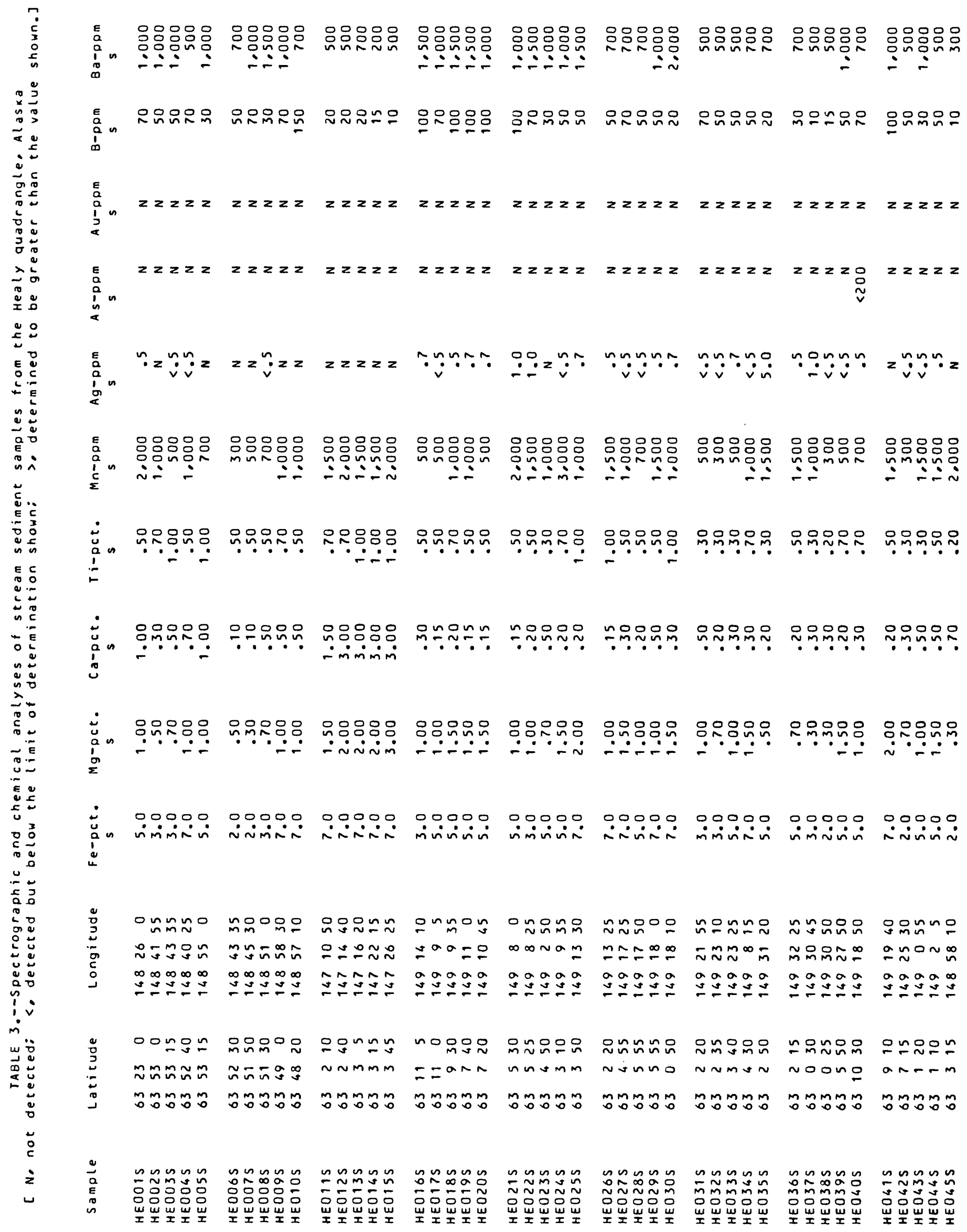


E⿱

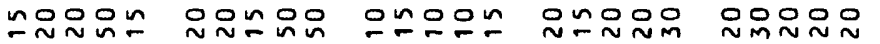
a

$E$
$a$
$a$
$:$

goooo onoo

응요으의의

은은우으 웃옹응 웃윰음

옷웅으은

웃으옹

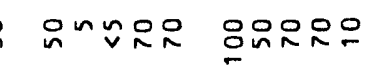

E
a
!n
$b^{2}$

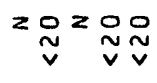

$z z z z 2 z z z$

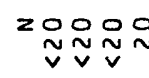

$\underset{\sim}{\sim} z=20$

$z \underset{\sim}{\sim} \underset{v}{\sim} \approx$

$\underset{\sim}{\sim} \underset{v}{N} \underset{v}{N}$

$\underset{\sim}{\stackrel{0}{v}}=2 \underset{\sim}{\sim}$

E
$i_{0}^{a}$
$\sum^{a}$

$z z z z \quad z z z z$

$2 z 2 z$

$n z n z z$

$2 \ln n \sim$

$\operatorname{zin} z$ in

$z \sim n z v$

$\mathfrak{v} \mathfrak{v} \geq n$

$n z n n z$

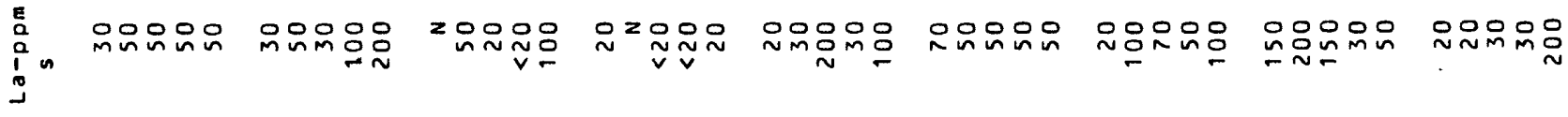

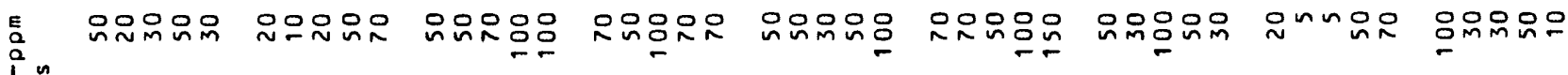
$\sum_{3}^{n}$

E⿱

000

응응ㅇㅇㅇㅇㅇㅛ

응응ㅇㅇㅇㅇㅇ

응응ㅇㅇㅇㅇㅇ

응응ㅇㅇㅇ음

응응옹으은

은응으웅

웅ㅇㅇㅇㅇ

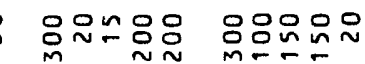

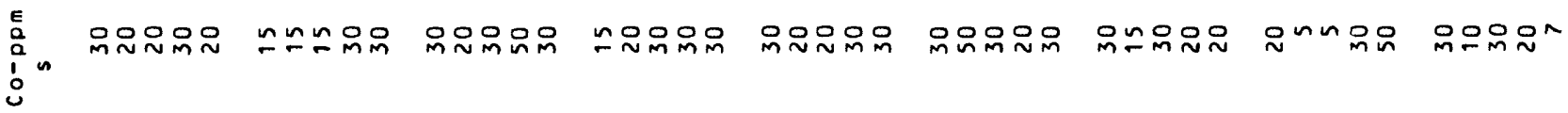

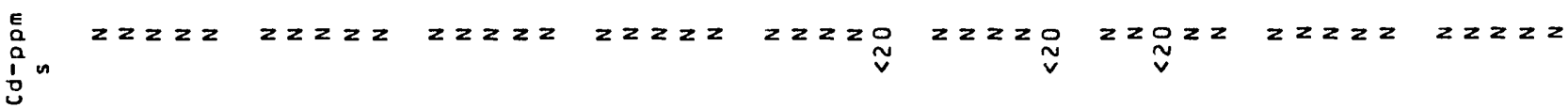

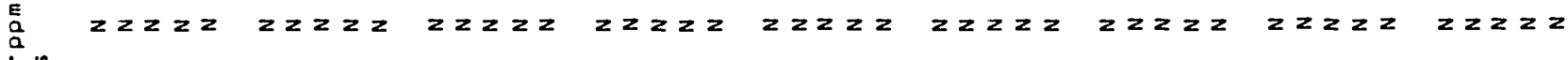
$\therefore$

E
a
$\vdots$
$\vdots$
0

$\because 00 \div \div$

$0.00 .9 n$

$0,0000.00000$

onoon

ononn

nninoo

inoodoo

onoon $\bar{v} \bar{v} \bar{v}$ $\therefore \therefore \therefore$ i...$\therefore-\therefore$ 


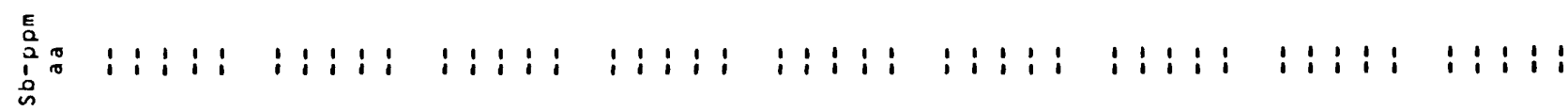
产。

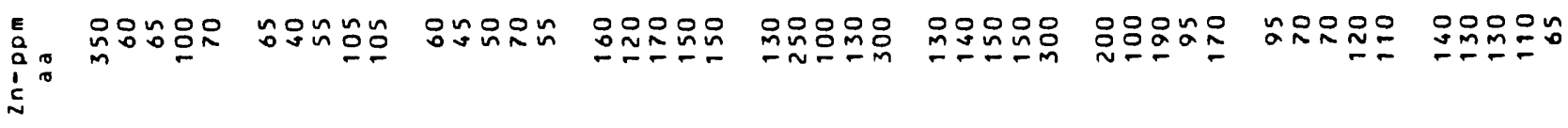

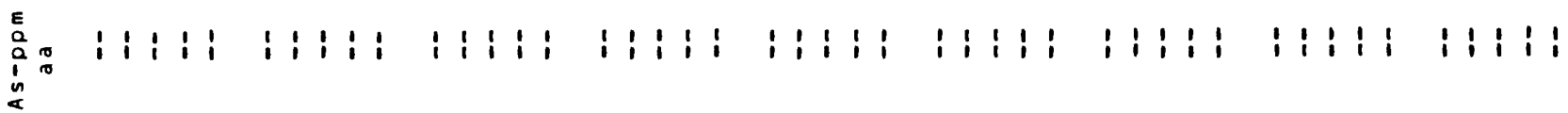

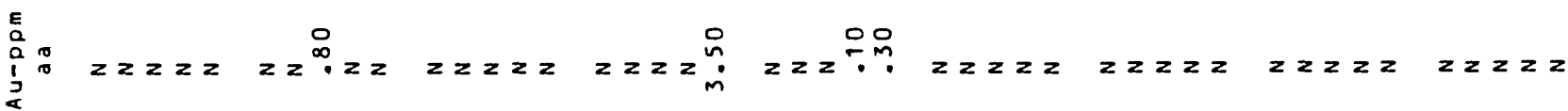

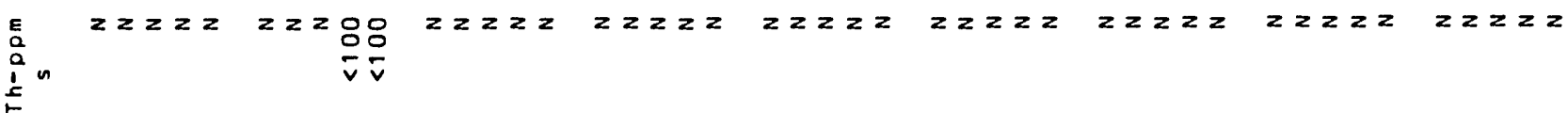

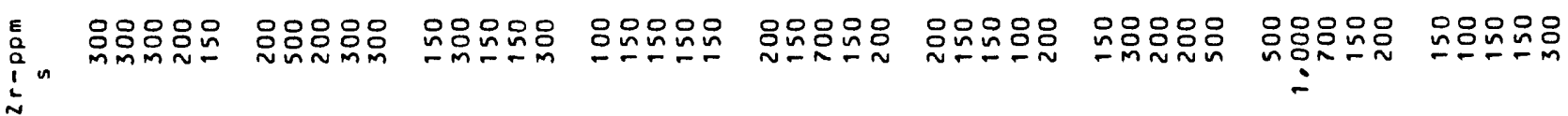

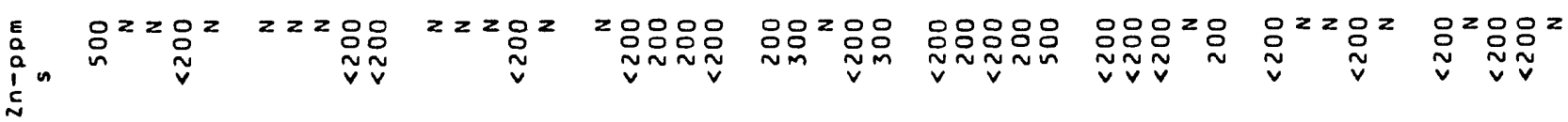

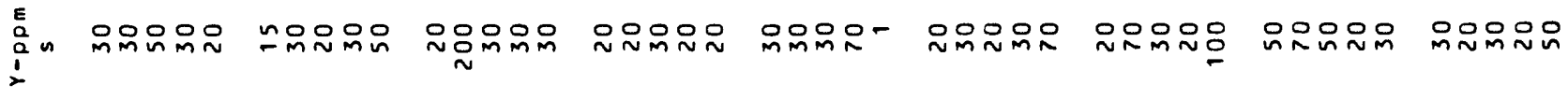

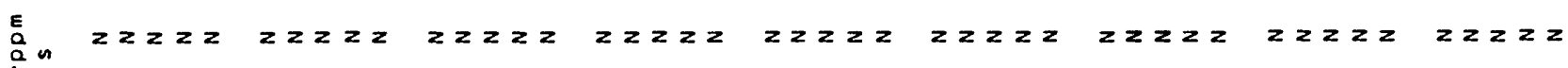

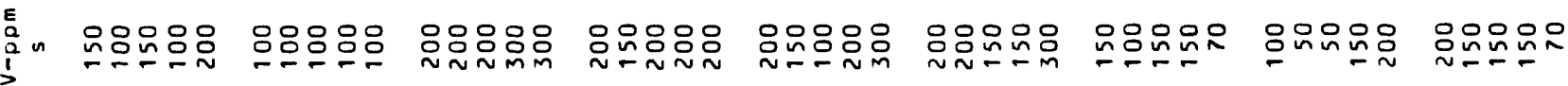

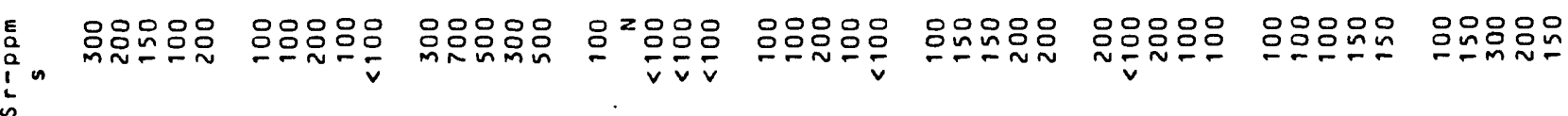

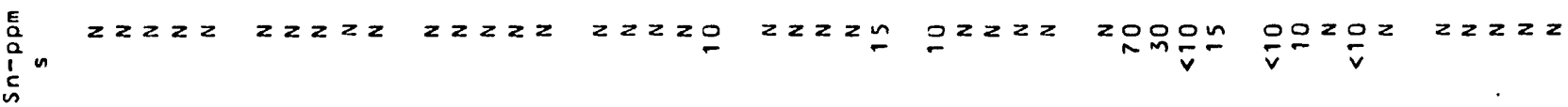

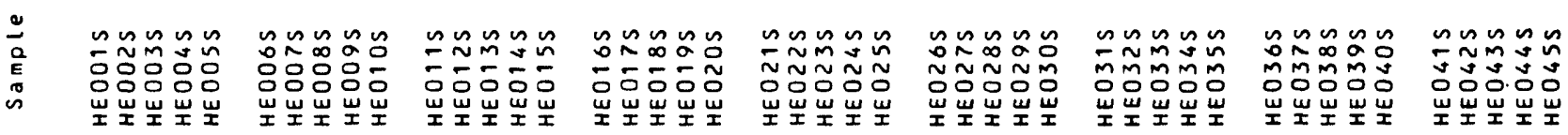




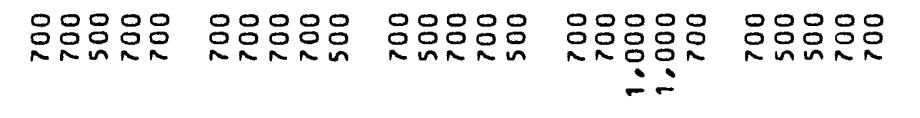

웅윰윰요

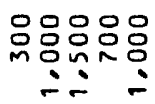

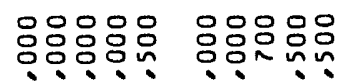

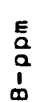

noo oo goinno

으눙무요

웃융유

읍으으윰우

운요옴오

웄유옹요

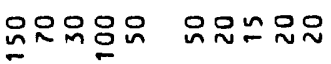

E
an
$i^{2} n$

$z z z z z 2 z z z$

$2 z 2 z 2$

$z \geq 2 z$

$z \geq 2 z$

$z \geq z z$

$2 z 2 z$

$z 2 z 2 z \quad z 2 z 2$

$\sum_{a}^{E}$

$z z z z z \quad z z z z z$

$z z z z$

$z z z z$

$z z z z$

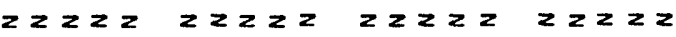

$E$
$\vdots$
$\vdots$
$\vdots$
$a$

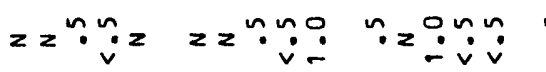

$\because 0 n n=$

$\tilde{v} z \geq \dddot{n}_{v}$

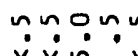

กฺnฺฺ

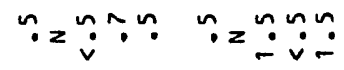

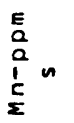

응ㅇㅇㅇ

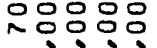

웅요웅

in

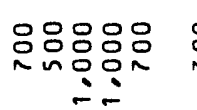

응ㅇㅇㅇㅇㅇㅁㅇㅛ

옹ㅇㅇㅇㅇㅁㅇ

เที่

vivi

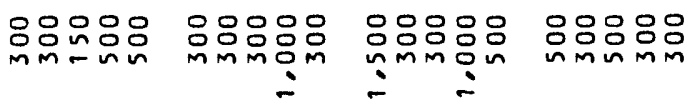

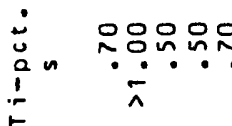

00000

윳음웄요

음웅ㅇㅇ

웅오우요

ก

웅ㅇㅇ음

웅유웅

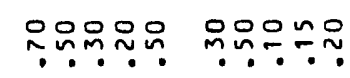

范

응오웅요

응ㅇㅇ웅

$\cdots \cdot$

?

-.・

00000

00000

oonoo

oonoo

nooon

nonno non응

$\because \because \because \because \because$

$\stackrel{\leftrightarrow}{0}$

융응으웅

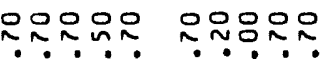

유응요용

운융ㅇㅁ운

은읍융요

웄임ㅇㅇ음

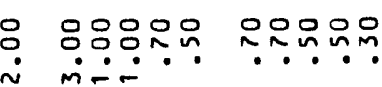

$\frac{1}{2}$

+ 0000000000

nivinivin miniñ⿻日乚

00000 -.-

जiniving

00000

00 no 0

00000

00000 !

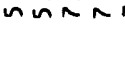

minini

mंinini

Nimin:

00000

$00 n n n$

n우음의 ํำนที่ง

$\infty \infty \infty \infty \infty$ さேざざ

nongn

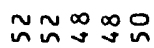

$\infty \infty \infty \infty \infty$

さேさささ

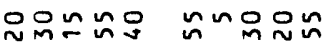

$0000 \mathrm{~N}$

моำกำ

- 000

공ำ

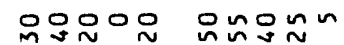

윤ํํㅇ

$\infty \infty \infty \infty \infty$

エさささざ mosos

00000

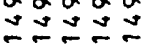

늠유음ㅇ

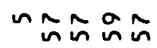

$a_{\infty} \infty \infty \infty$

エேさささ

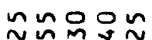

ำテレn

$\infty \infty \infty \infty \infty$

さささささ

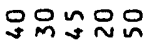

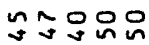

$\infty \infty \infty \infty$

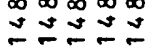

ㅇำกㅇำ

$\sim \sim \infty a \infty$

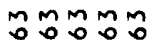

운ํํㄴํำ $\check{ニ ニ ニ ー ~}$

ำกำ.ำ
잉영영 nnn

mimmon

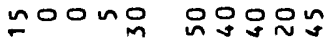
유:ニ

м⿻ำ

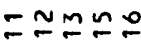

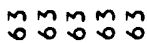

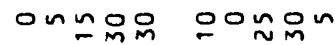

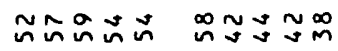
$\infty \infty \infty \infty \infty \infty \infty \infty \infty \infty$

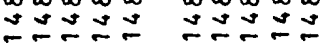

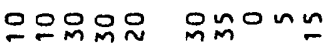
오프 Madn mMmmm

Мำกำ

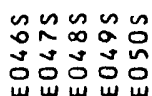

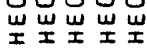

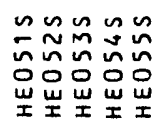

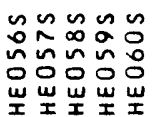

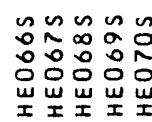

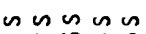

$\overline{1} \tilde{N} \Sigma \tilde{ก}$

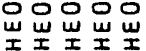

$\sim \sim n \sim n$

$\bar{\infty} \tilde{\infty}_{\infty}^{\infty} \sum_{\infty}^{n}$

00000

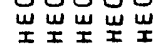

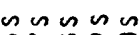
$\therefore \hat{\infty} \infty \propto \infty 0$ 0

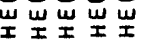




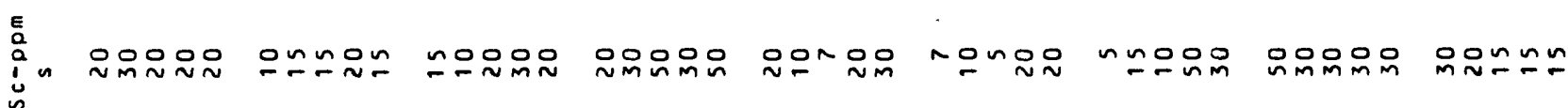

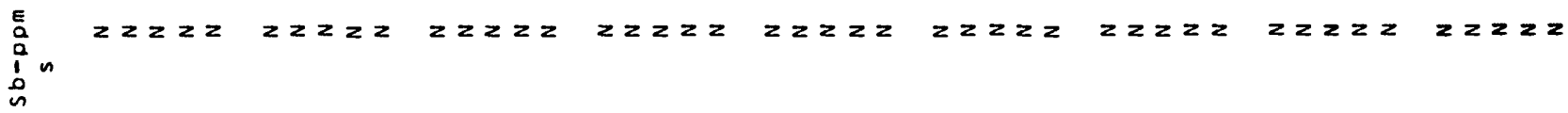

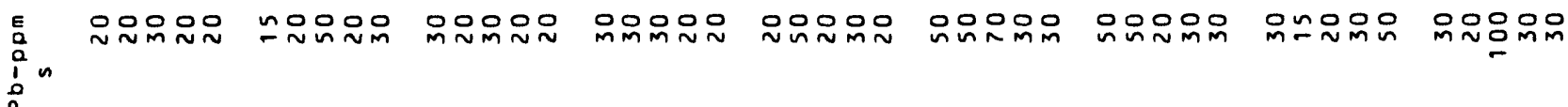

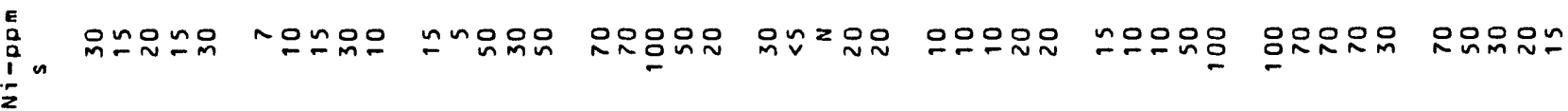

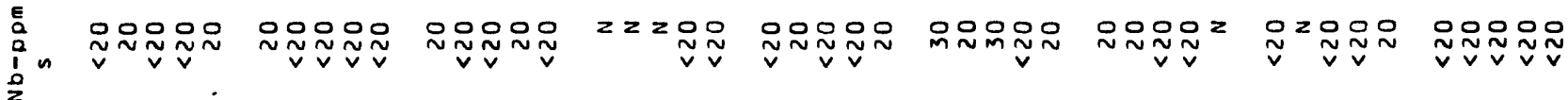
$E$
$\mathfrak{a}_{n}$
$\mathfrak{o}^{\prime}$

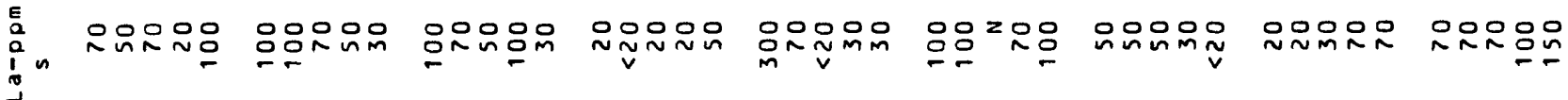

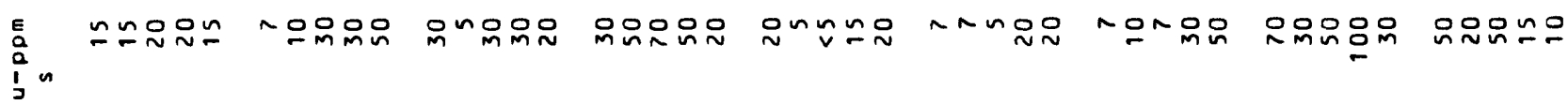

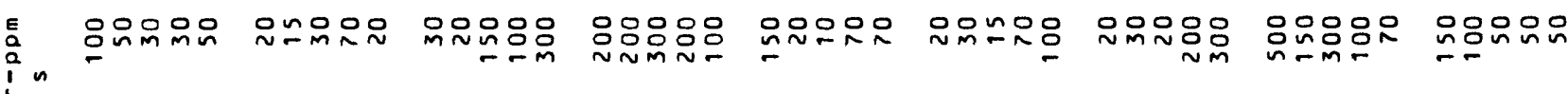

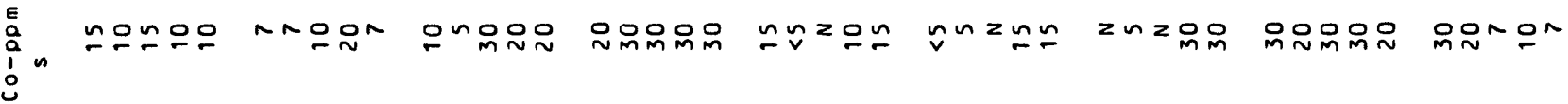

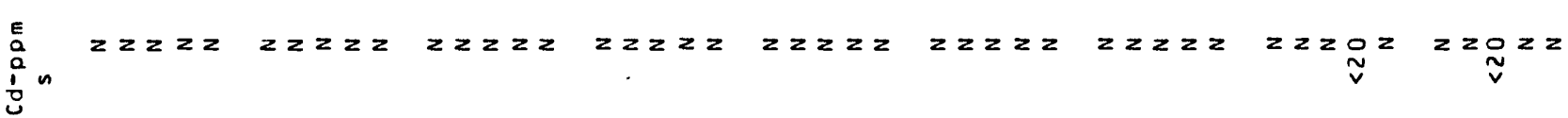

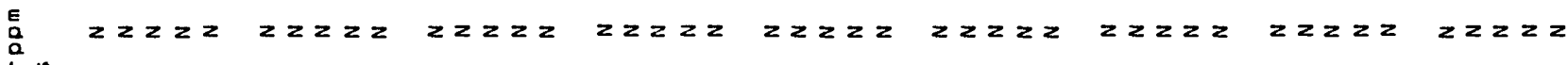
$\therefore$

E

$00000000 n n 00000$

$00000000 n 000 n 0000000$

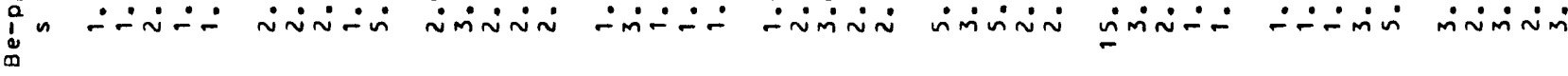

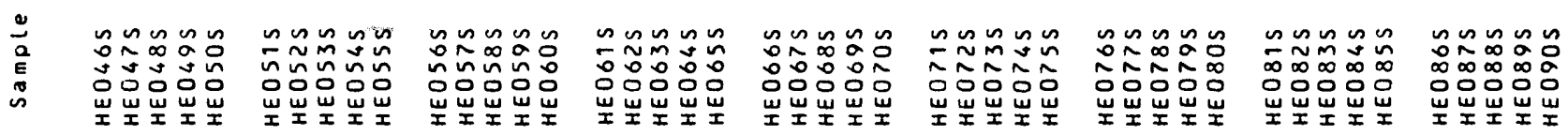




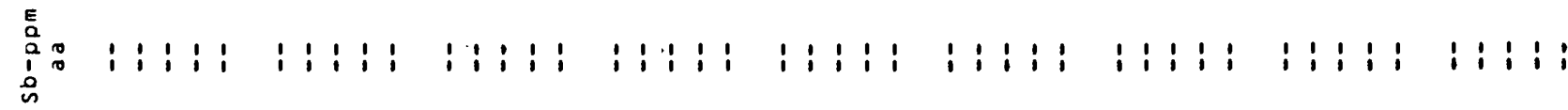
镸

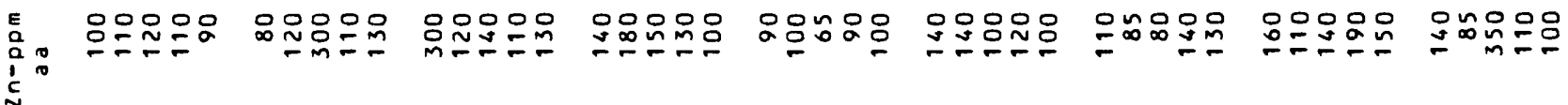

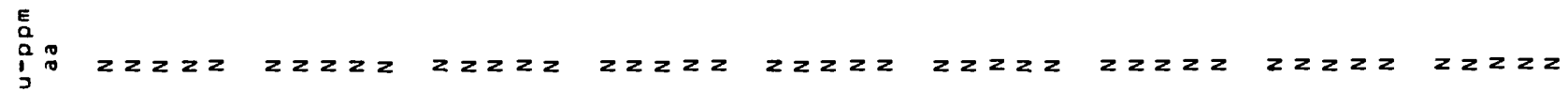

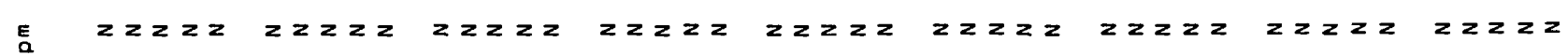
in

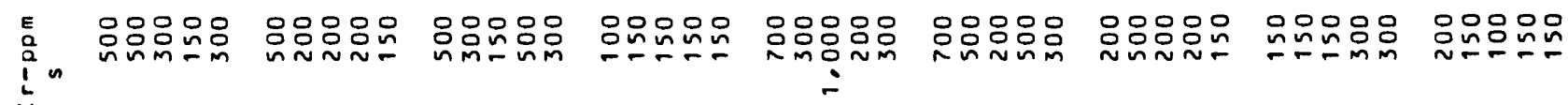

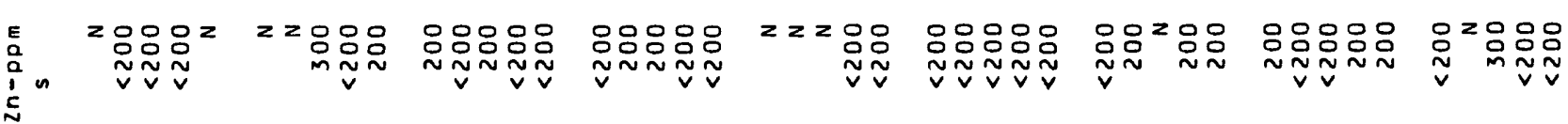

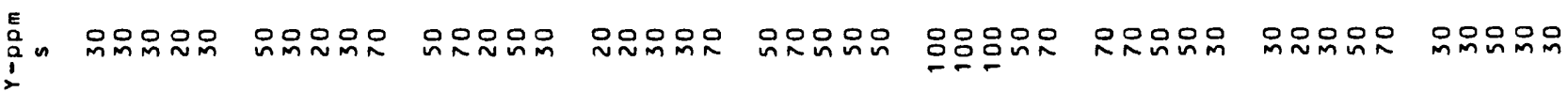
E⿱

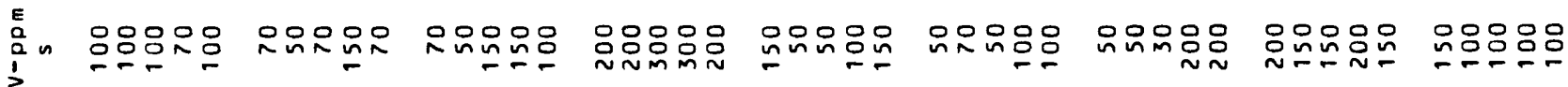

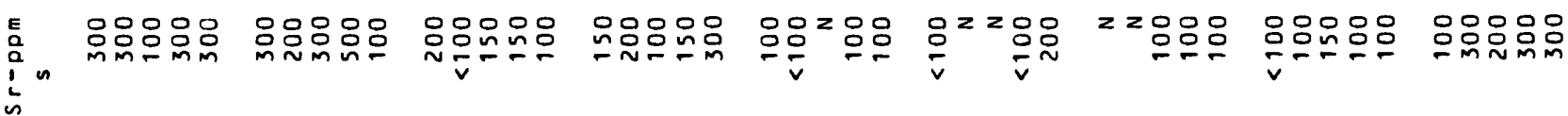

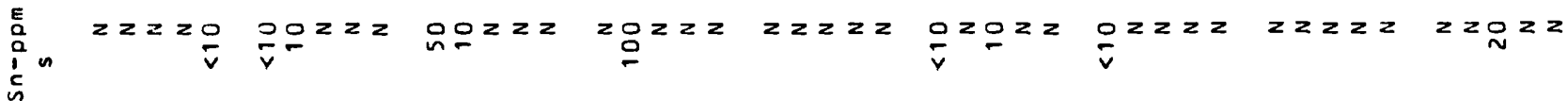

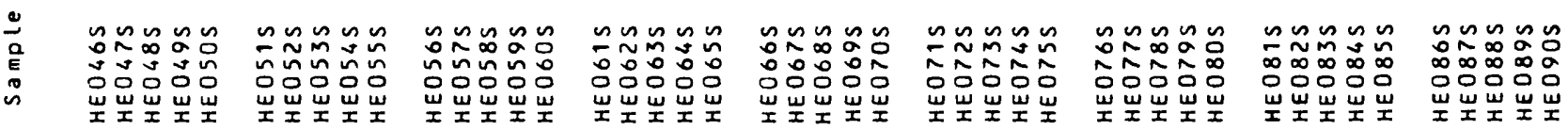


onouno oooon onnun poono oopoo

Q

$\because \div \div \div$

$\therefore:$

量

$z \geq z z 2$

$z \geq 2 z$

$z \geq z z z$

$z z z z$

$z z z z$

$z z z z$

$z z z z$

$z z z z$

$z z z z z$

E
$a$
in
in

$z \geq z z$

$z \geq 0 z=$

$z z \geq z$

$z z 2 z$

$z \geq 2 z$

$z 2 z z$

$z \geq z z$

$z z z z z \quad z z z z$

$\frac{a}{a}$

$\tilde{v} \geq \tilde{v} z=$

$\dddot{v} \dddot{n} \because z$

$\tilde{y} \geq 2 z$

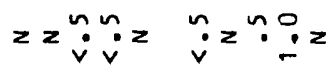

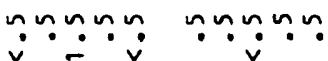

$z \tilde{y}^{n} z z$

$z \tilde{v} \tilde{v} z z$

ह

\section{옹응옹ㅇㅇ음 \\ $\because \div$ \\ 음응응응응 \\ 응옹ㅇㅇㅇㅇㅁㅇ $\because \because$ m}

옹응옹옹웅

응옹음응

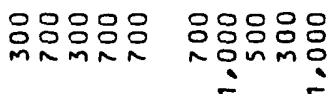

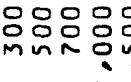

옹ㅇㅇㅇㅇㅇㅇㅇㅇㅇㅇㅁ

$\stackrel{0}{u}$
$\stackrel{1}{a}$

00000

$\because \because \div$ m.

앆윤웅유오

은은운온

ㅇํำำ

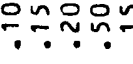

ํํำำ

온으는

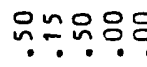

은온ํํำ

$:$
$u$
0
0
0
$u$

응운읏 응운으는

응응옷ㅇㅇㅇ

읐옹음음

압으능응

융ㅇㅁ음

non $\because \frac{n}{?}$

으능우은

옷ㅇㅇㅇ유은

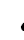

$\dot{1}$
àn
$\vdots$
$\vdots$
In

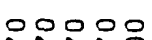

กากั

응응음으

웅ㅇㅁ

$-$

$\cdots$

은운은으 은믕응으

눈

응으응응

응응응우웅

은옹ㅇㅇㅇ음

$\because \therefore-$

$\because \because \div$

옹응응음

$\because \therefore$

- noono 00000 000no 000no nooo

- - -

$\because 00 \backsim 0$.

inimin

$\dot{m i n} \dot{\sim} \dot{x}$

inimin

$\therefore$ inis

00000

00000

00000

$000 n n$ : (1)

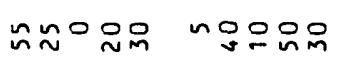
mOำ

$\infty \infty \infty \infty \infty$

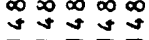
$\tilde{m} \tilde{m} \bar{m} \tilde{m} \tilde{m}$

$\infty \infty \infty \infty \infty$

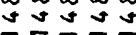

으ำํํ유 $\tilde{\sim} \sim \sim \infty ⿻$

$\infty \infty \infty \infty \infty$ $\underbrace{\infty}_{0} 0$

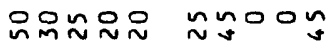

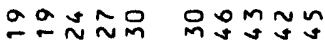

$\infty \infty \infty \infty \infty$

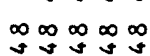

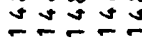

レニュ

onตn

으늠용요

m이용ํํ

onusm

N NOO-

N N N

mo m

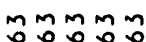

$m M m M m$

०ONOD

กำmno

요요

mo

mัต

ำㅇำ

ํำ

món $\begin{gathered}m \\ 0\end{gathered}$

으능요 ouำ

$\infty \infty \infty \infty \infty$

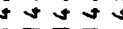

으ำำ 씄옴ㅇ

$\infty \infty \infty \infty \infty$

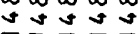

onn

$\stackrel{\infty}{\sim} \sim \simeq$

$\infty \infty \infty \infty \infty$

ง

nnnoo

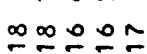

ㄴำ웅

$\stackrel{0}{0} \div \infty$

Mó

món
앙으욤ㄴ ำำ $\infty \infty \infty \infty \infty$ さンさざ

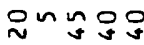
品ざ

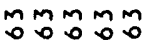

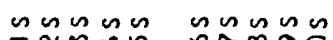

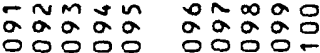

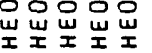

nnsines

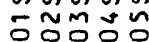
च $\bar{w} \bar{w}$

กุกละ ํํㅇㅇㅇㅇ

똗씨

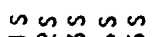
ニニะニ

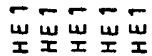

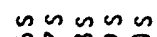
도음 해 $\bar{w}-\bar{w}$

sons n $\bar{\sim} \tilde{\sim} \tilde{N}$

ก⿻上丨 $\sim \tilde{N} \sim \sim 0$ w $\bar{w} \bar{w}$

cosenos 또ㅍㅗㅗ

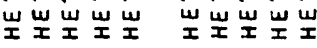




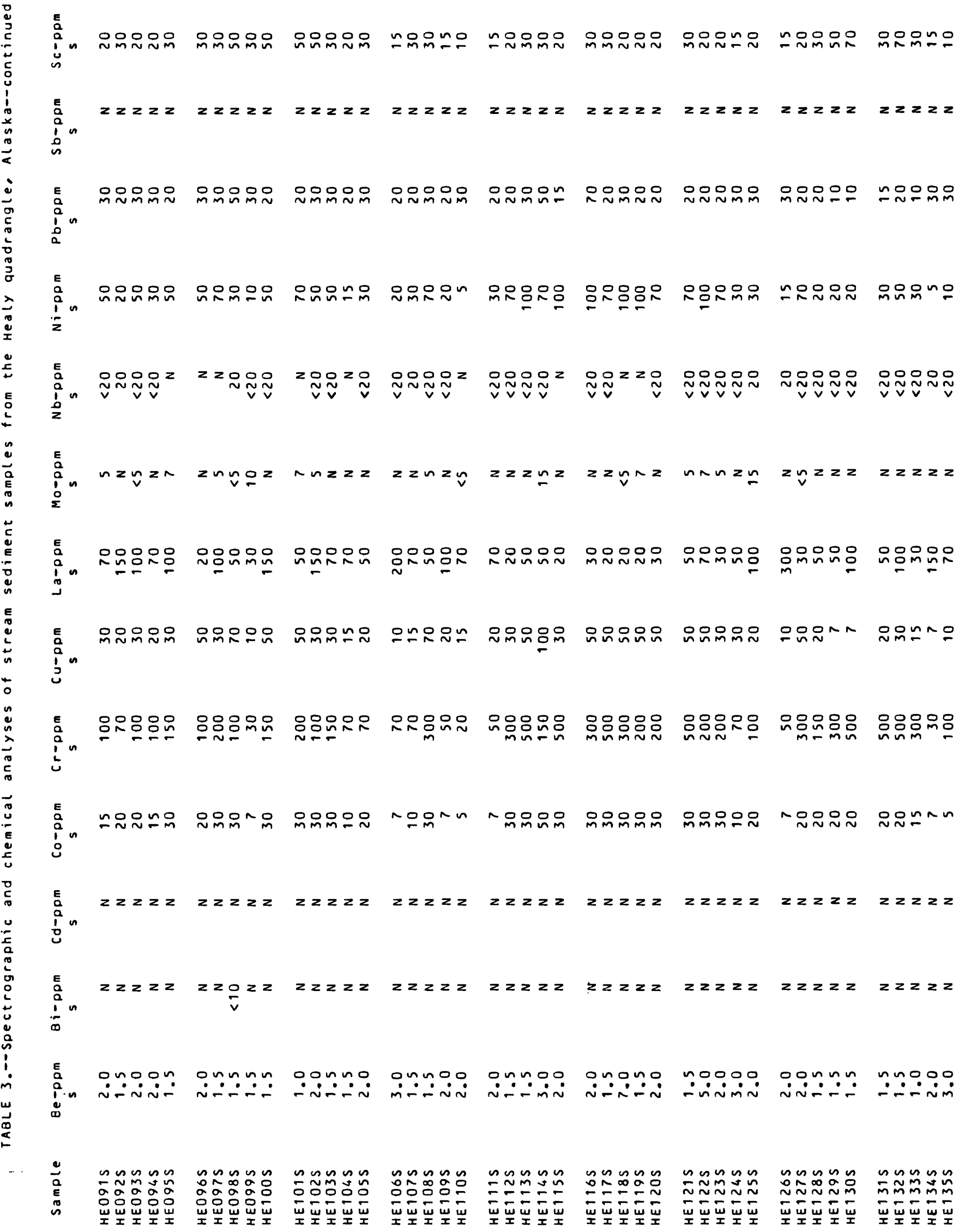




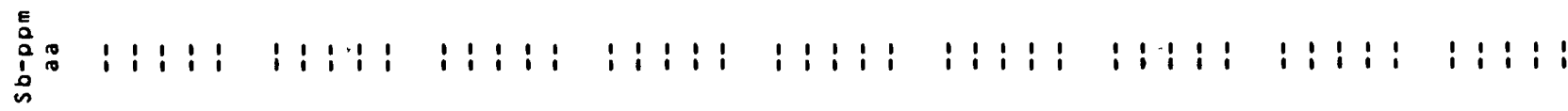

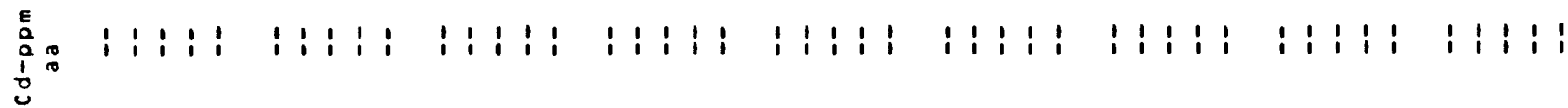

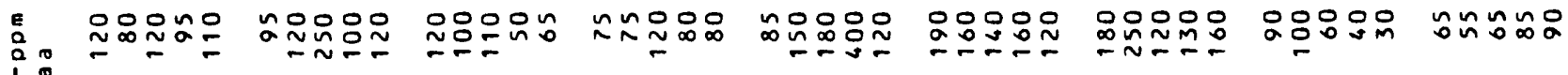
$\stackrel{1}{n}$

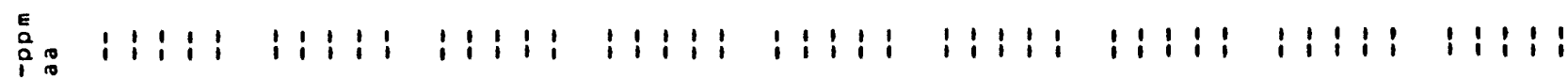

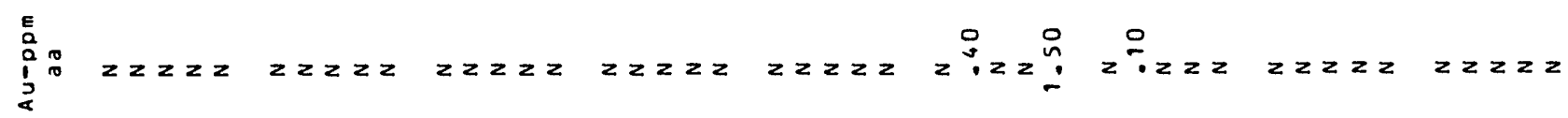

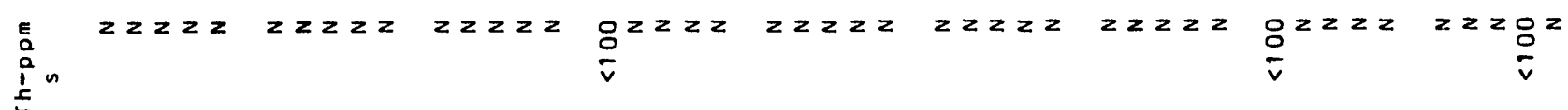

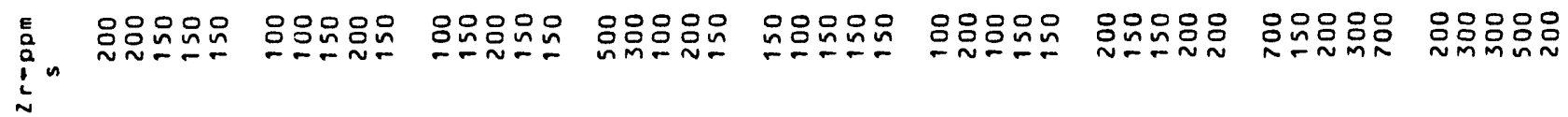

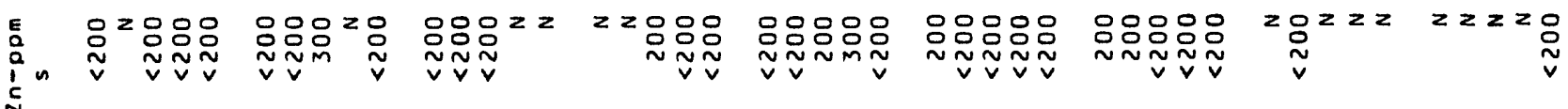

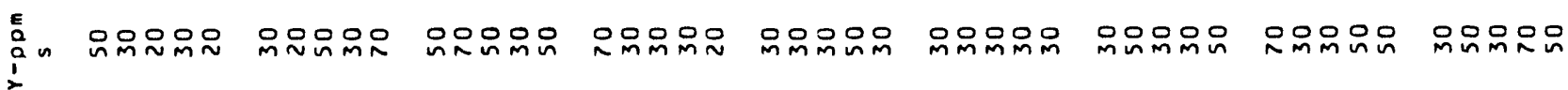

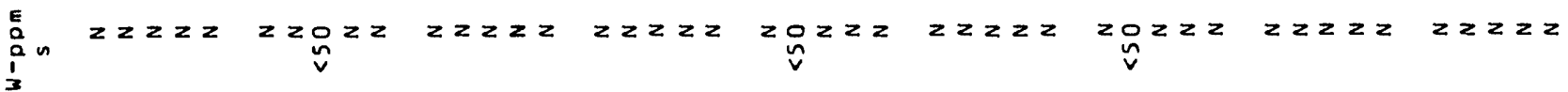

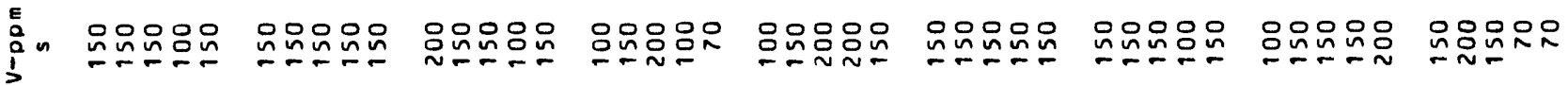

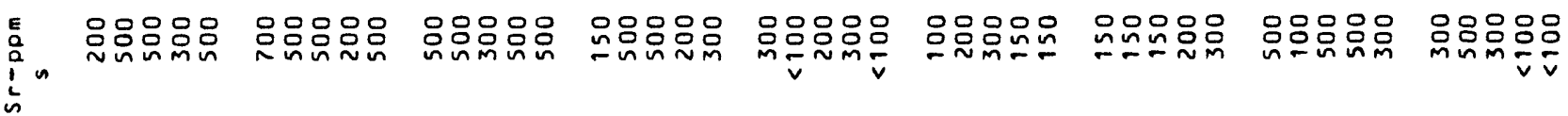
镸 $z z z z z$ a

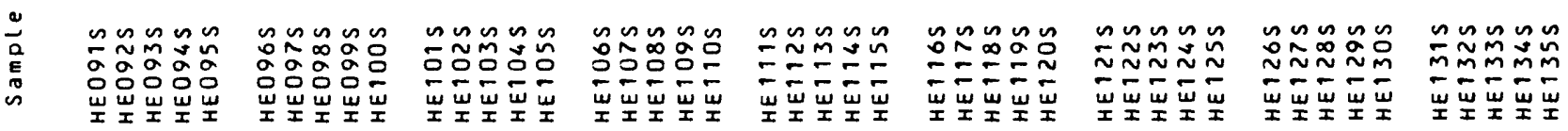




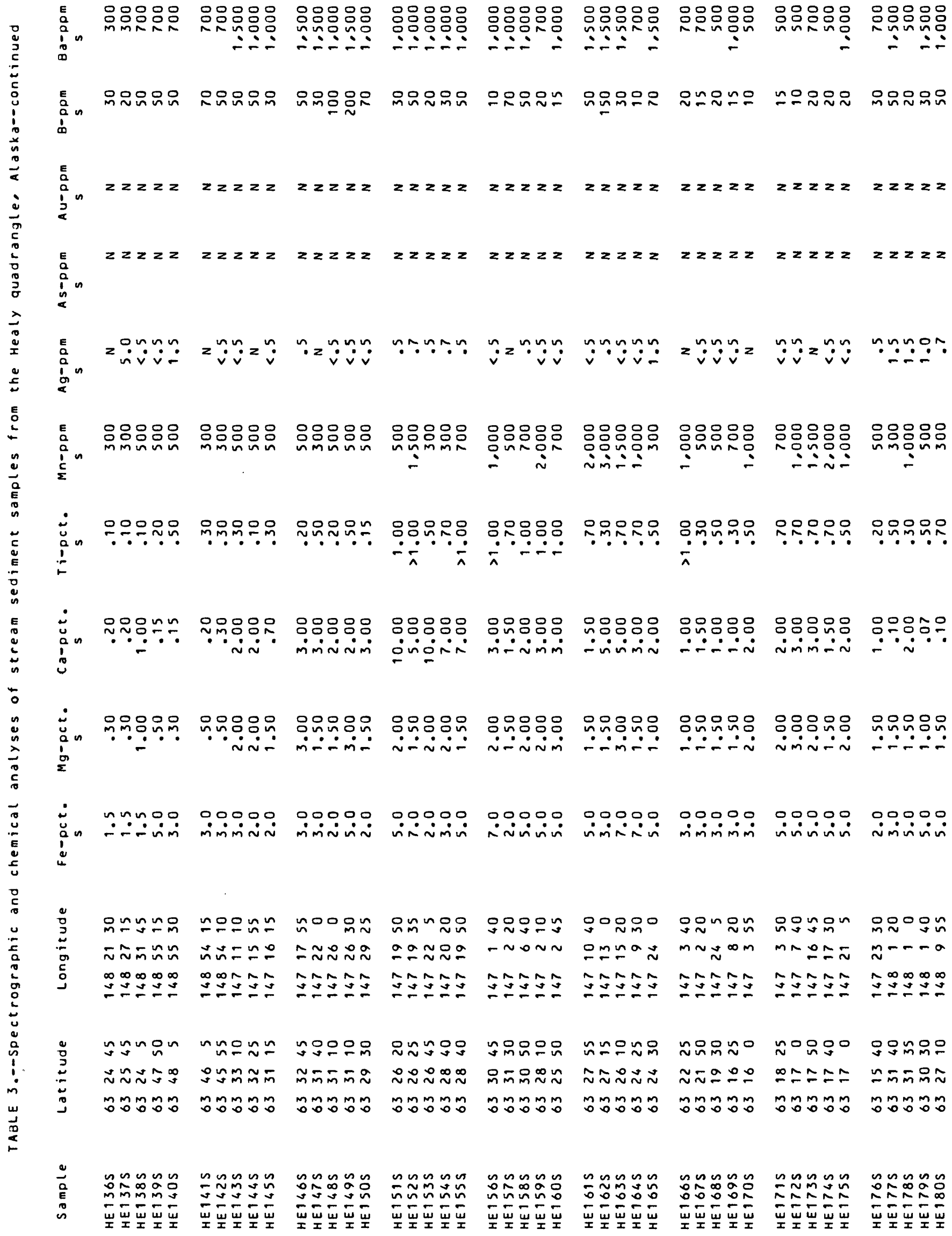




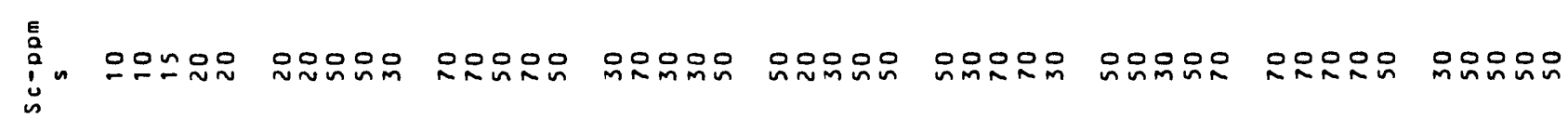

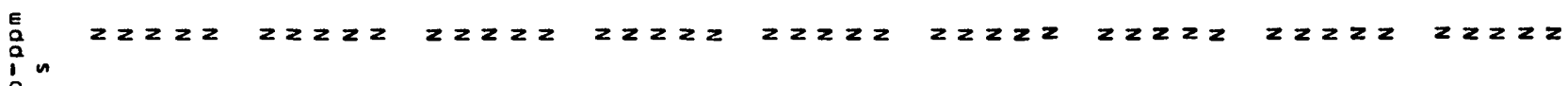
is

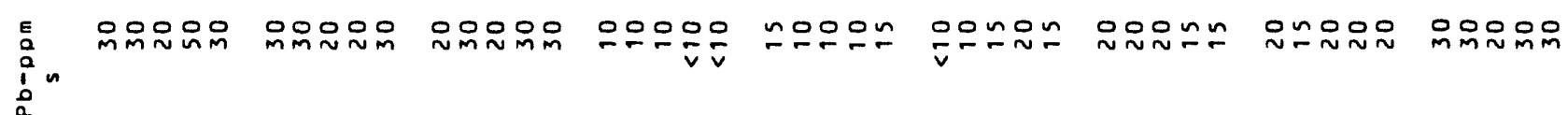

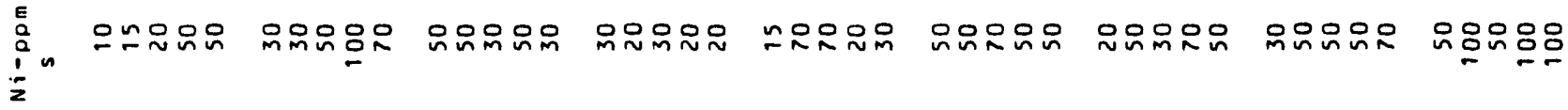

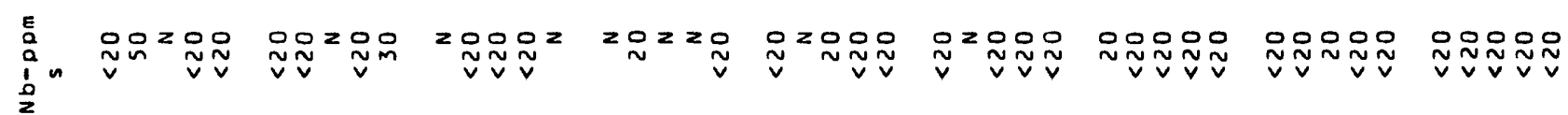

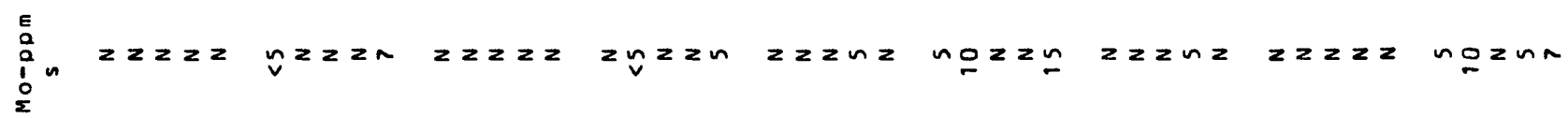

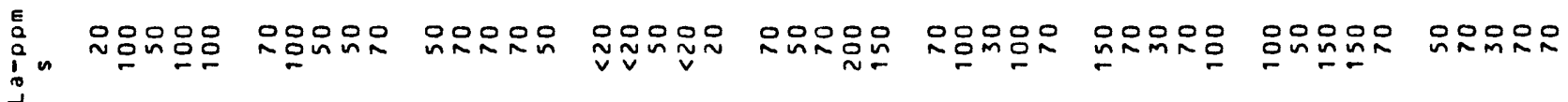

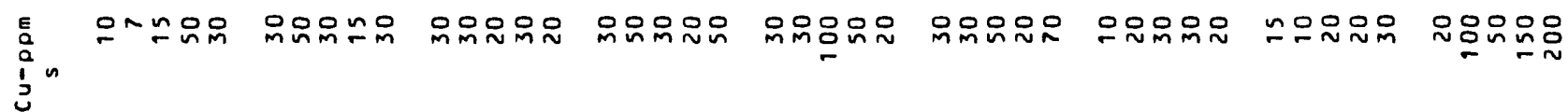

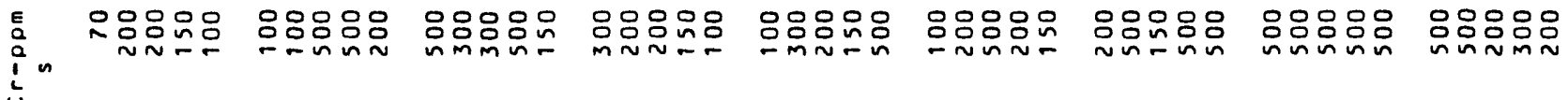

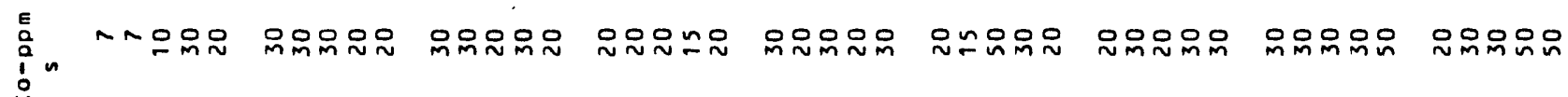

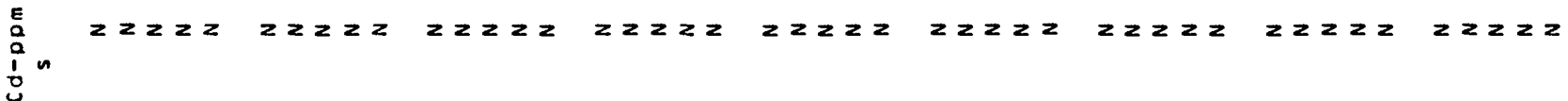

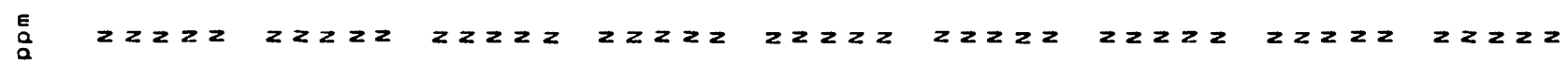
$\therefore$ 竞

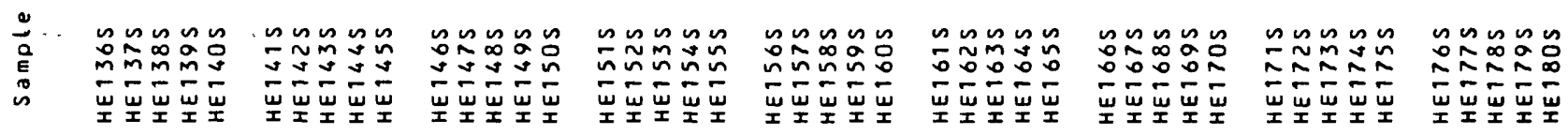




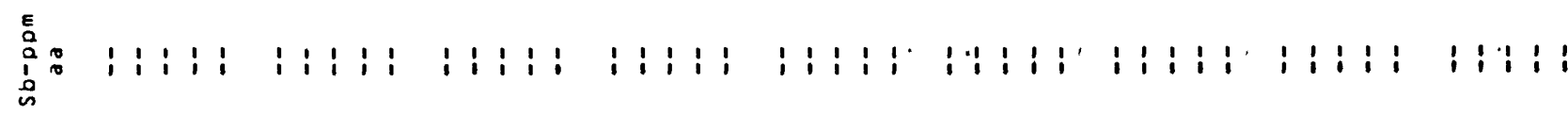
产

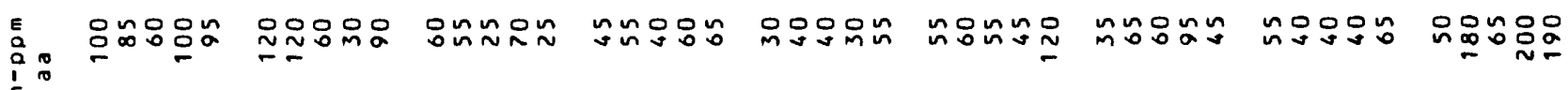
$\stackrel{1}{n}$

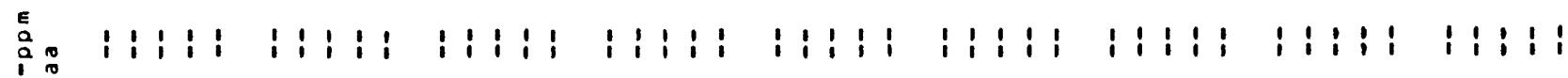
4

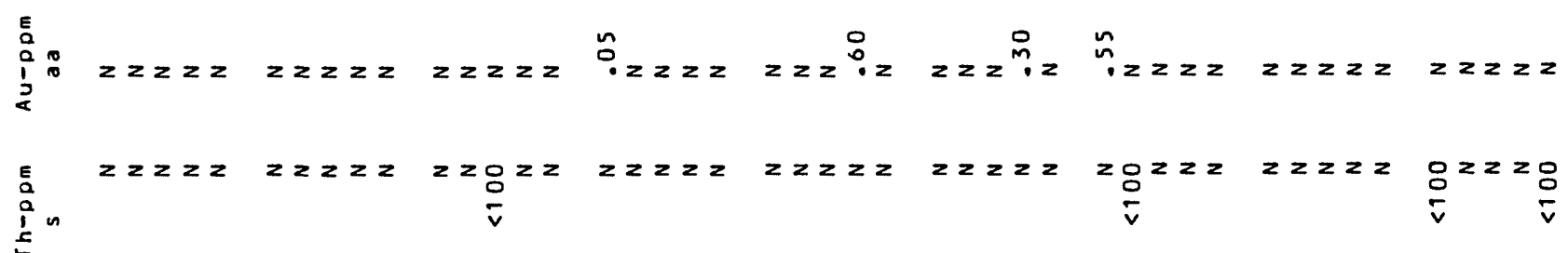

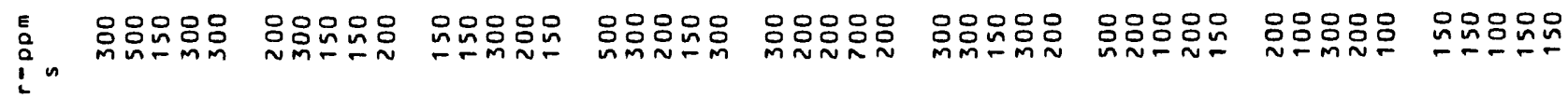
$\stackrel{2}{2}$

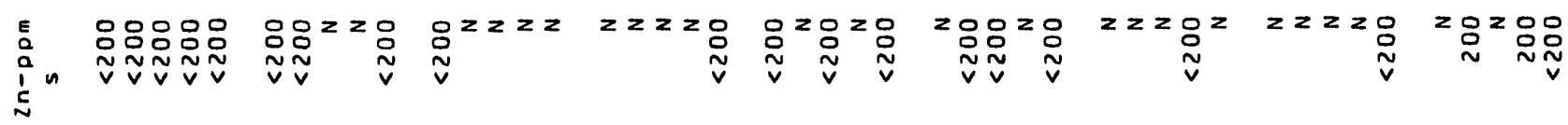

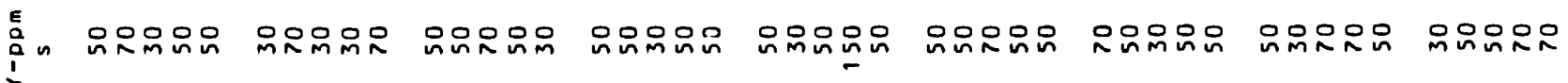

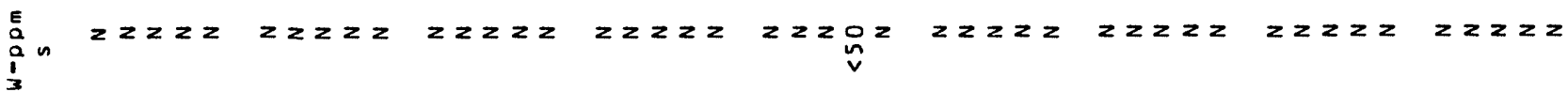

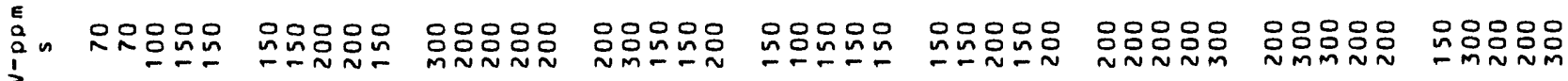

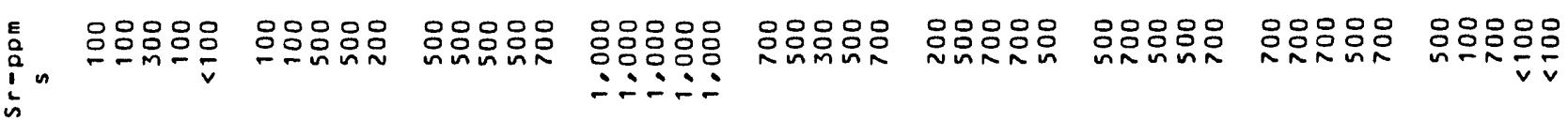

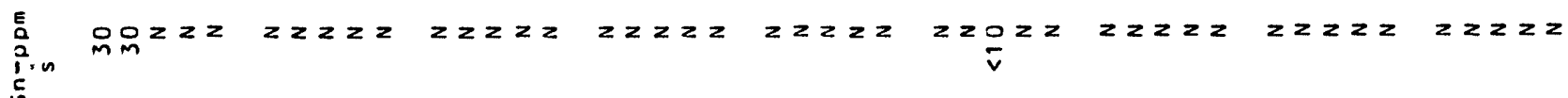

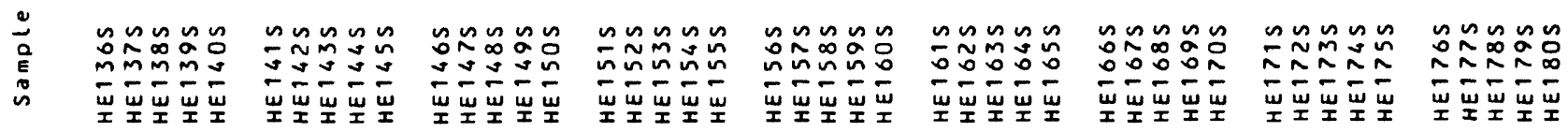




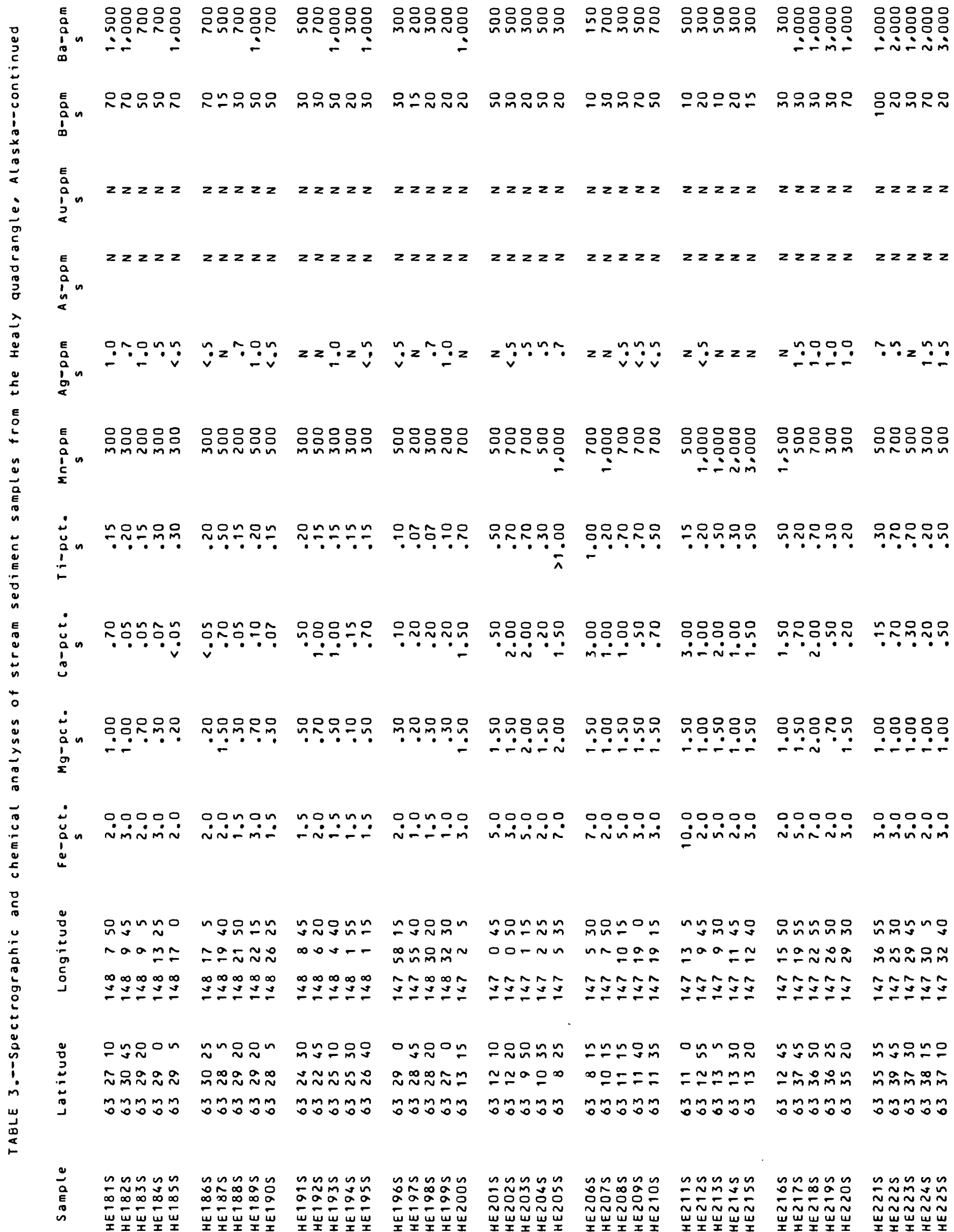

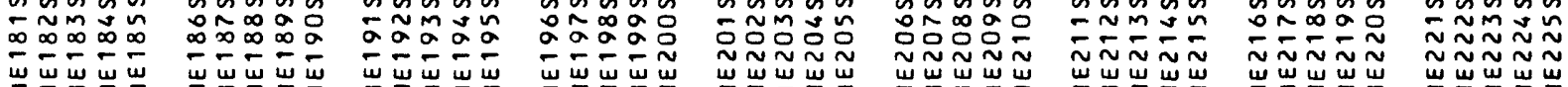




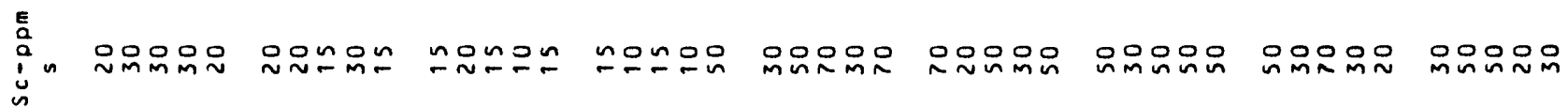
E
a
in
in

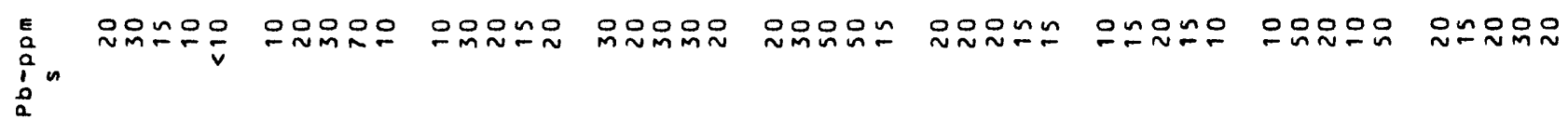

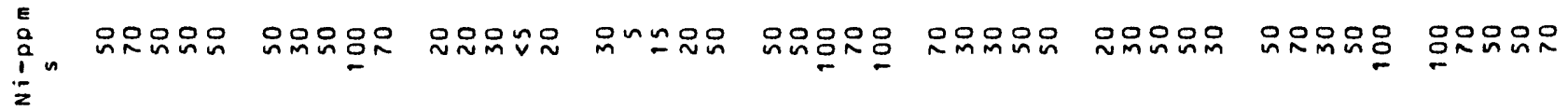

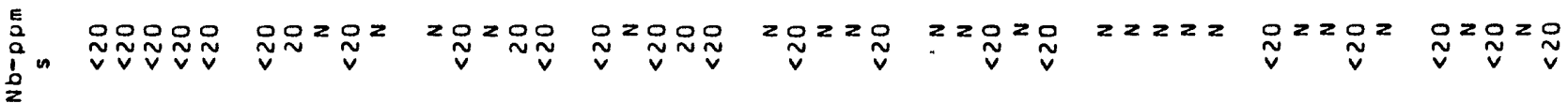
戛

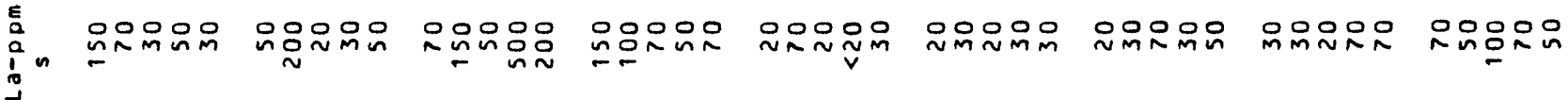

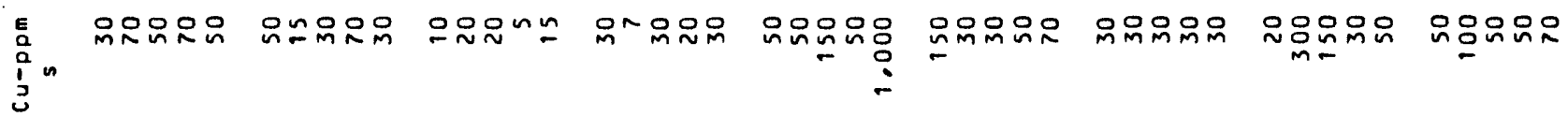

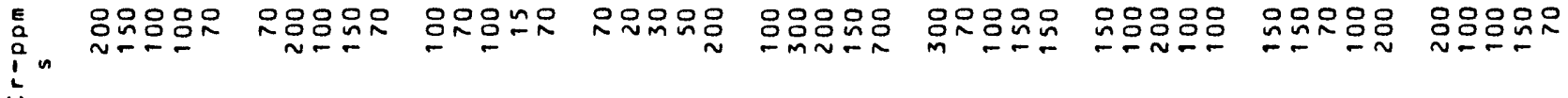

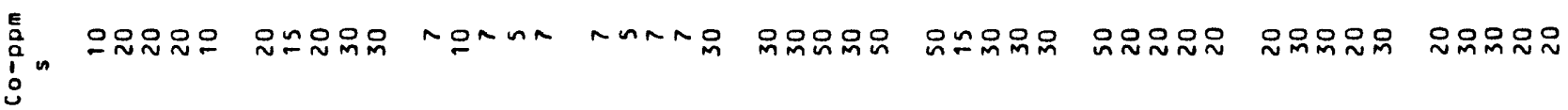

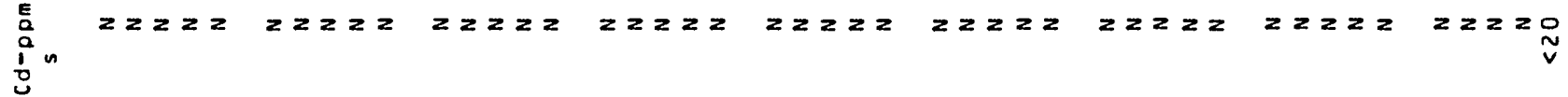

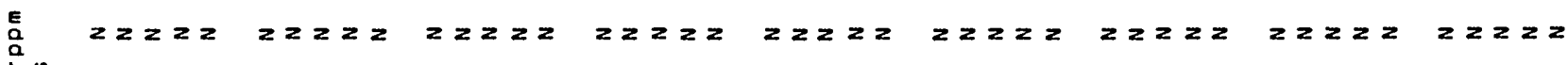
$\frac{1}{1}$

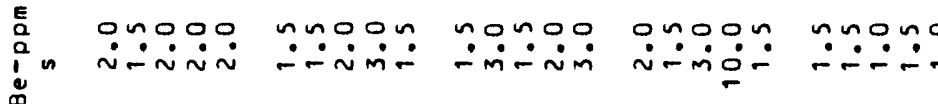
on 0 ino 000 no

onoon nomon (a)

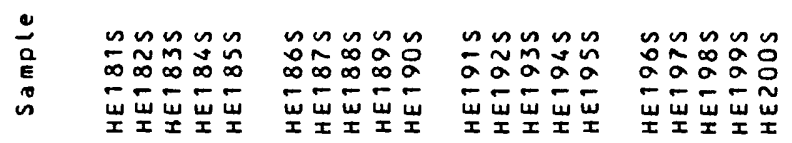

$\because \sim \sim \sim n$ 웅ㅇㅁㅇㅁㅇㅁ

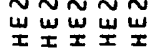

$\tilde{0} \sim \sim \sim n$ 운유문

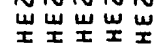

$\sim \approx \sim \sim n$ $\bar{\sim} \bar{\sim} \bar{N}$ $\bar{\sim} \bar{\sim} \bar{\sim}$

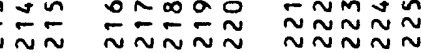

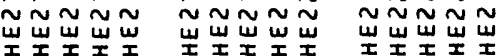




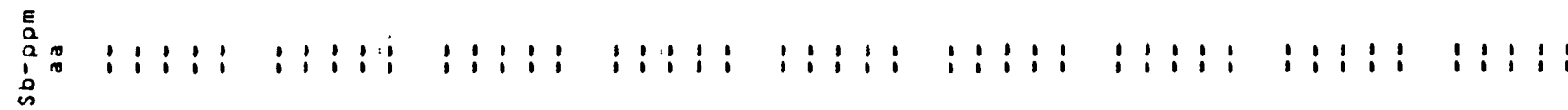

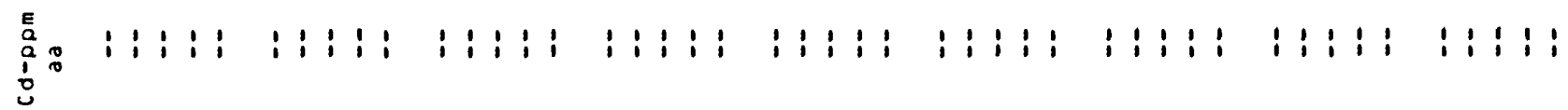

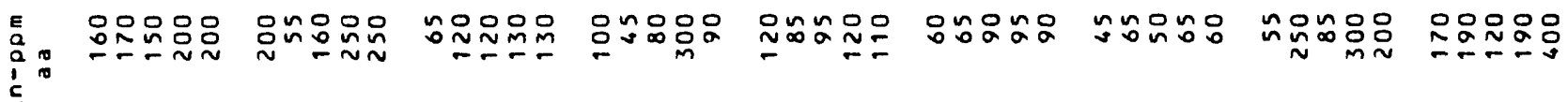

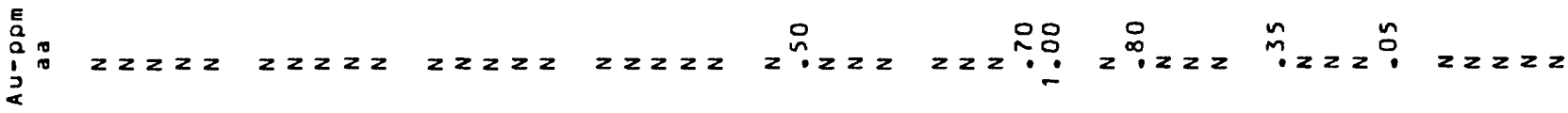

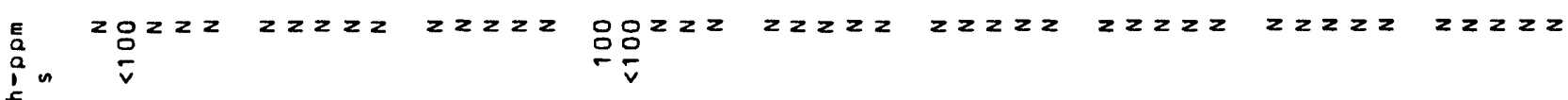

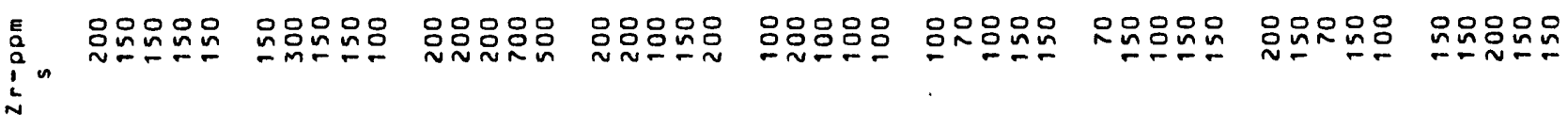

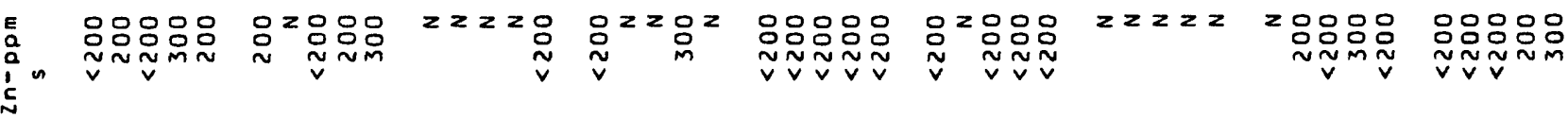

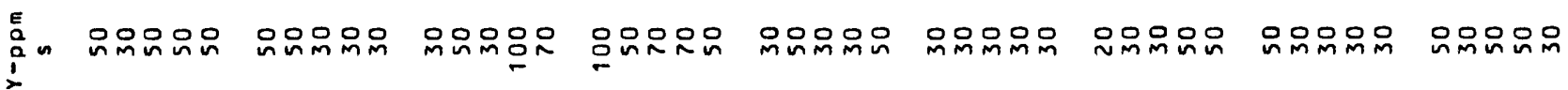

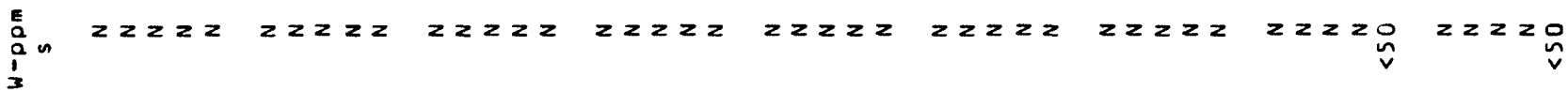

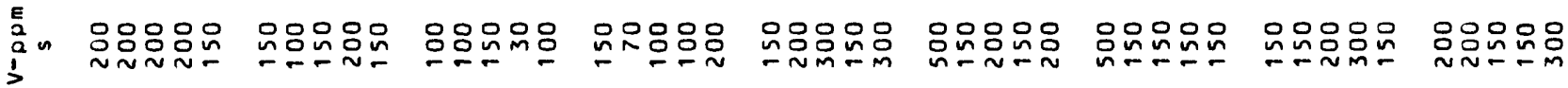

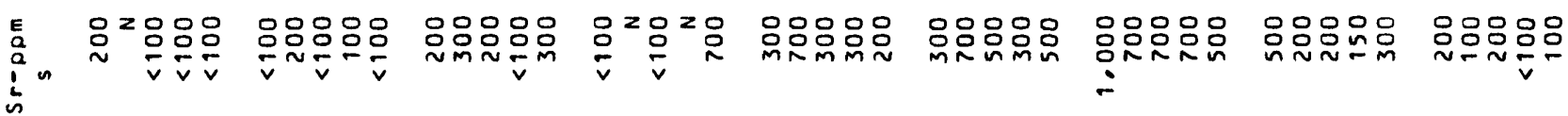

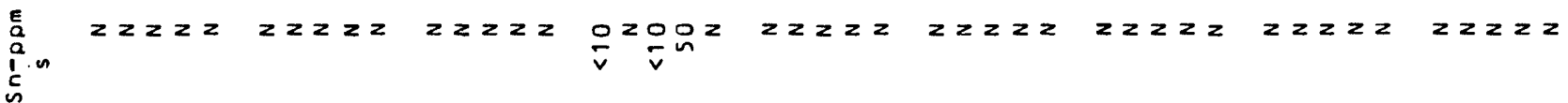

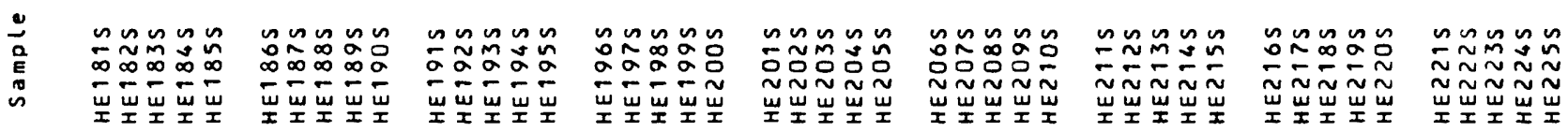




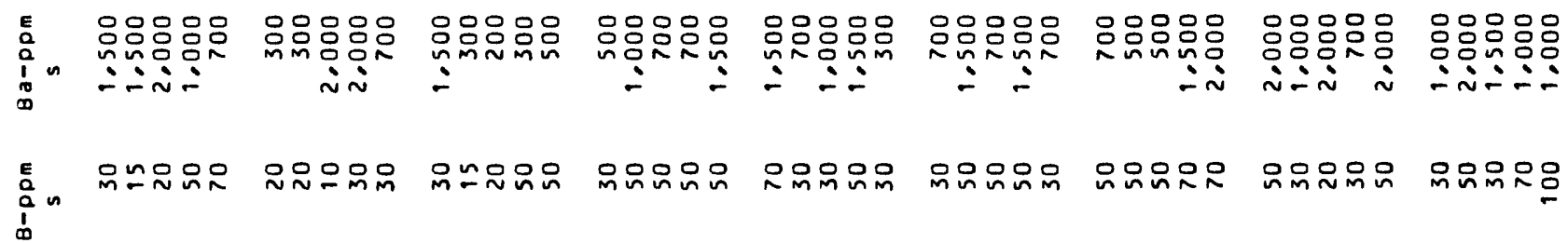

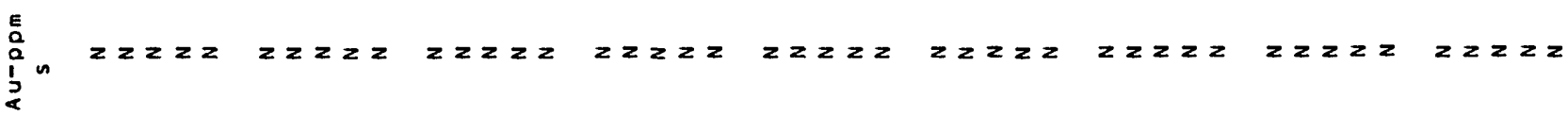

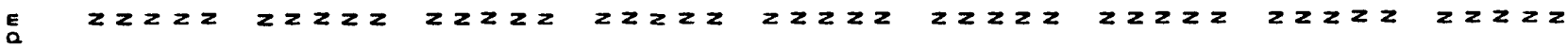
in

nnanon

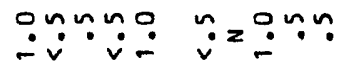

용요 minin

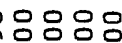
noin

웅요

웅요요

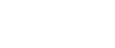
mmmim

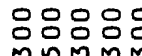
88888

\section{0} 응응ㅇㅇㅇ음

응응ㅇㅇㅇ응 응응응ㅇㅇㅇ

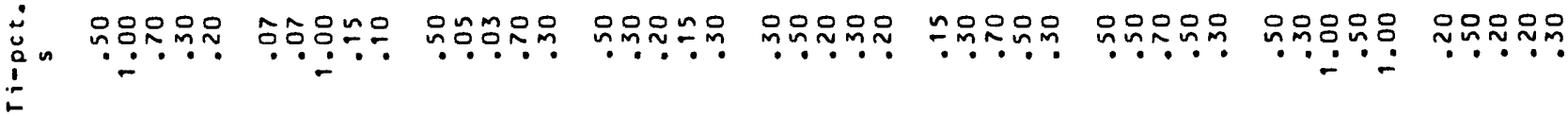

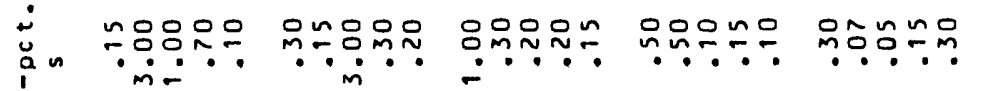

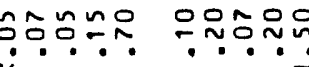

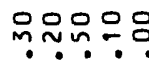
는온은 ¿ $\stackrel{\dot{0}}{\ddot{a}}$

00000 o 0000 $\operatorname{rin} 0.0$ ํㅜㄴ은요 은으은은

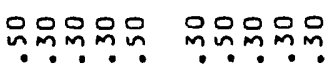
ํํㄴํํ용 응은믄응

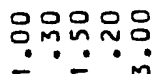

은으ㄴㅜㅗ은은

$\stackrel{\ddot{u}}{0}$ in

00000

onooo

ดทำ ด0ดก:

$00 n 0 n$

กำ:?

00000

$\because \because \because \div 0$

$\because 00: 0$

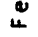

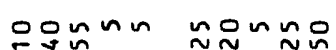
กำ두

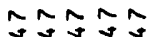

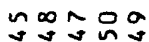

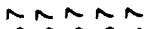

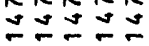

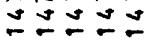

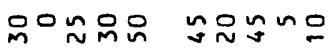
只的的品品

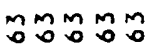
紋品品品 MDMDD

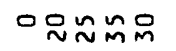
ํํำกับี

mỡ ทีํำ品会会

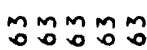

ำํํํํำ 스쇼요요

món

은웅으

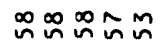

mำ

뜸ㅇㅇㅇㅇㅠ

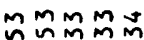

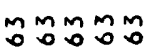

กัณกัน 웃ํํำ

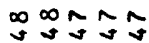

은은ํํำ

\section{u$$
\text { in }
$$

in $\infty$ ino

ヘNヘヘ ேะே

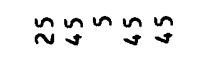

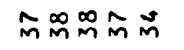
Mำ

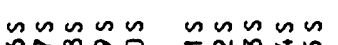

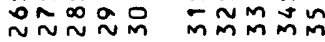
$\sim \sim \sim \sim \sim \sim N \sim \sim N$ NMMM

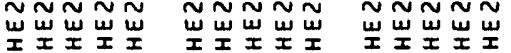

nnonn

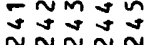
w出峲出 $\operatorname{nan} \pi \approx$

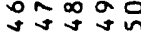

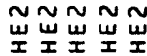

$\approx \sim \sim \sim \sim n$ En nñn $\sim \sim \sim \sim \sim N \sim \sim \sim N$

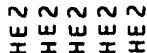

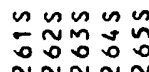
UN岕出出

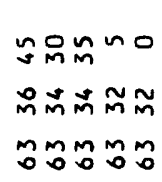

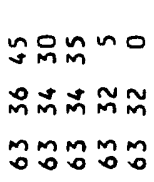

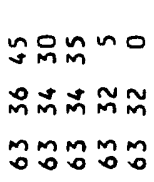

으의 non $\sim \sim \infty \simeq \sim$ $\begin{array}{lll}\infty & \infty & \infty \\ 0 & \infty & \infty \\ 0 & 0 & 0\end{array}$

ก⿻上กn

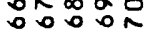
N N N N 岕岕㞬出 


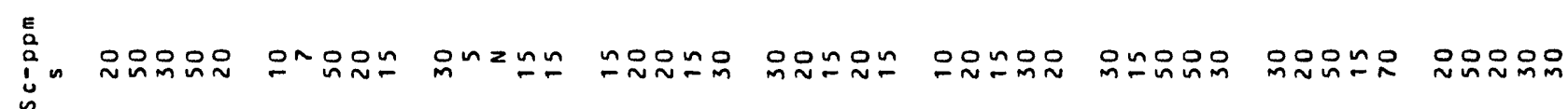
E b

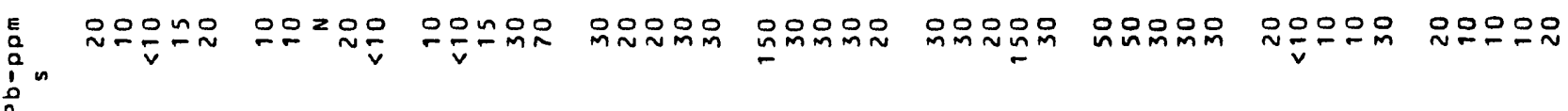

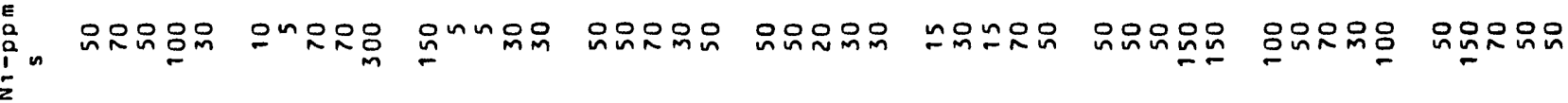

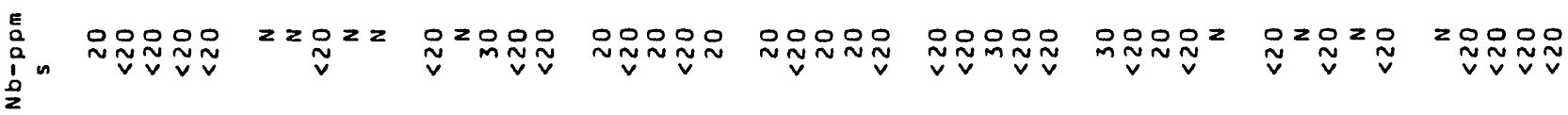
E⿱

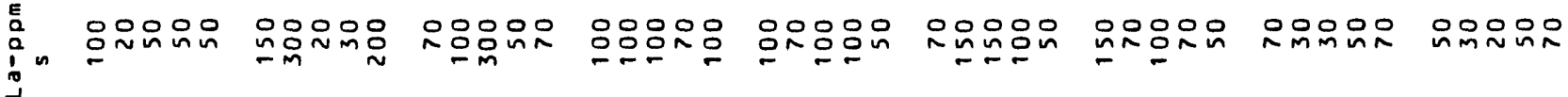

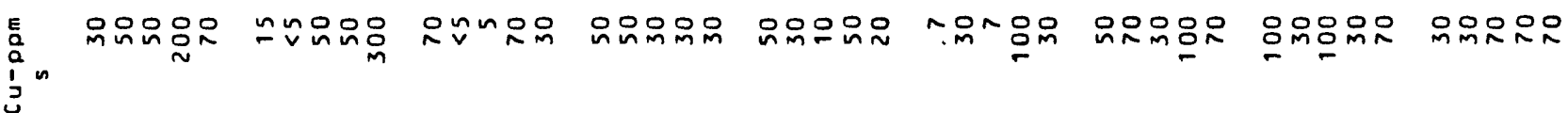

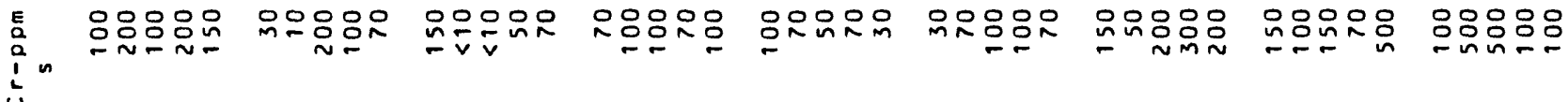

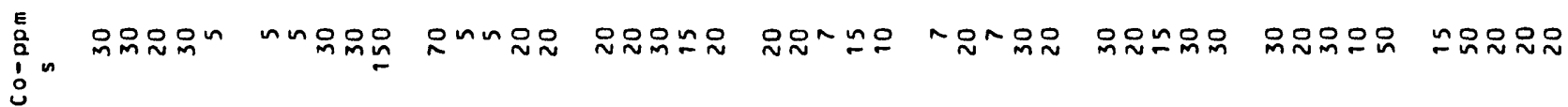

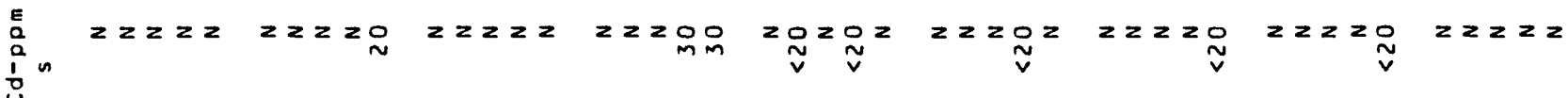

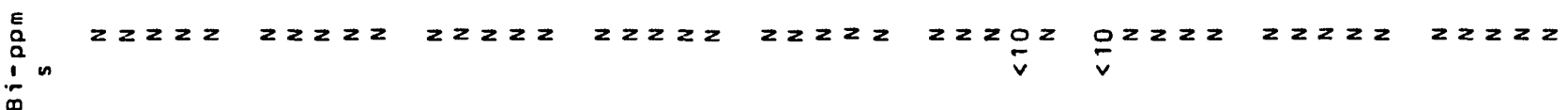

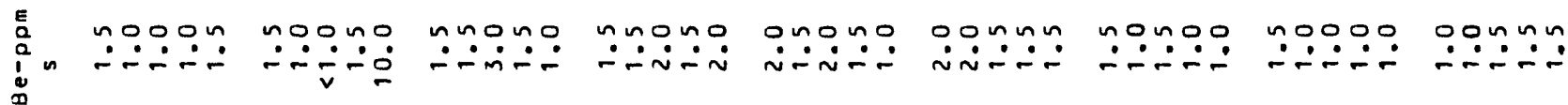

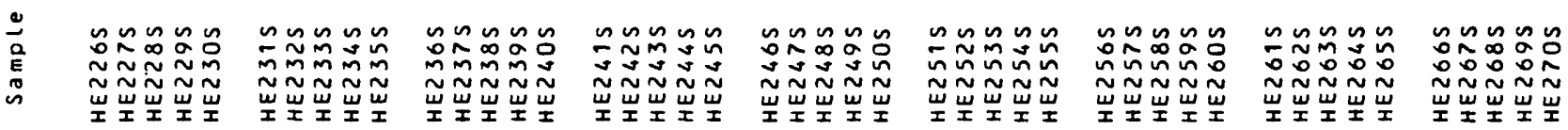


$\underbrace{0}_{0}$ :

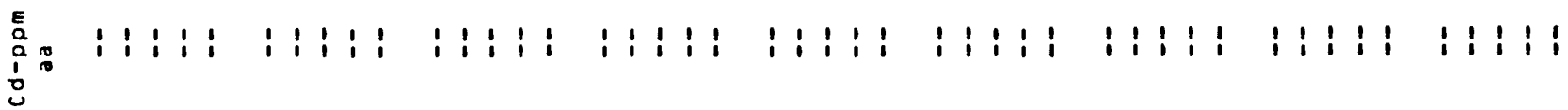

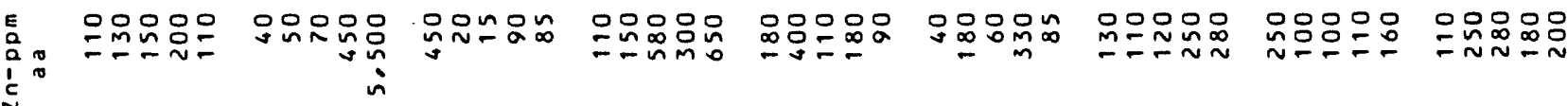

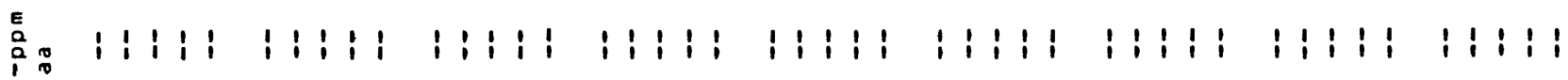

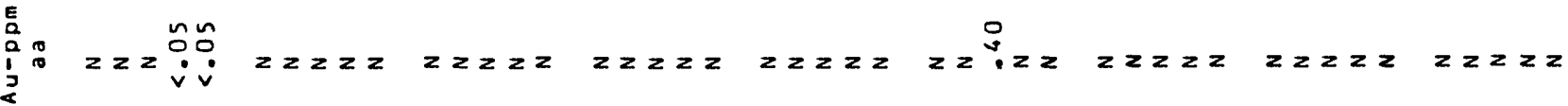

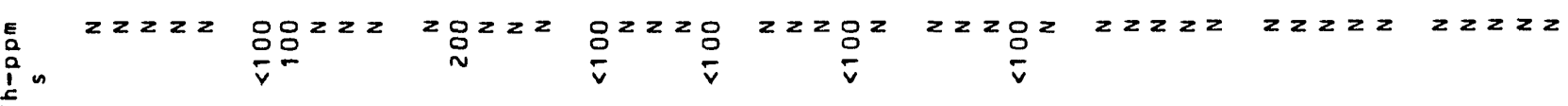

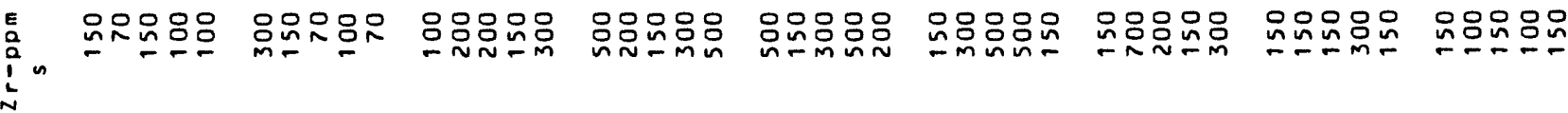

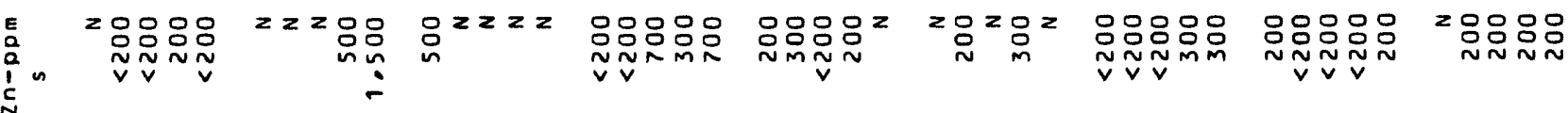

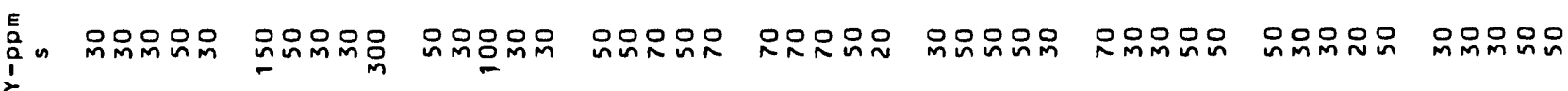

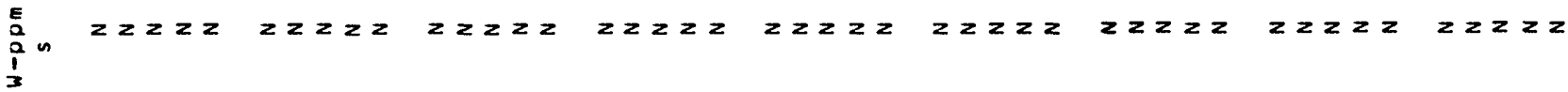

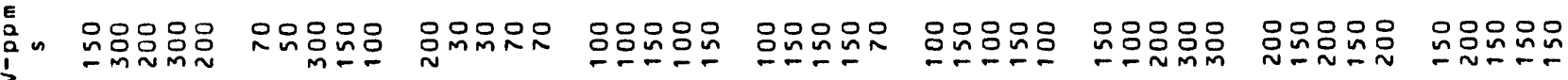

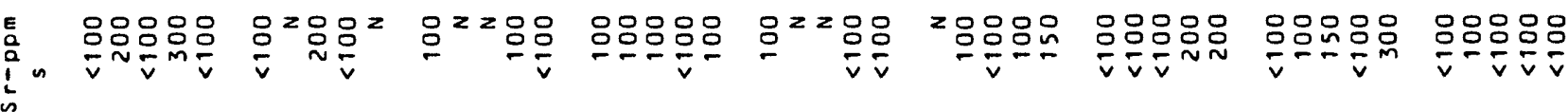

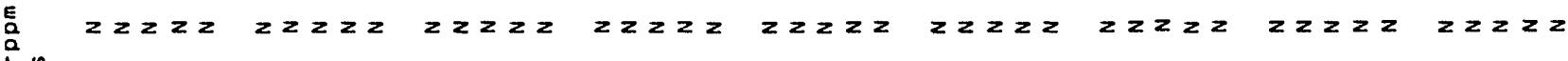
$i_{\text {in }}^{i}$

$\tilde{0} \sim \sim \sim$

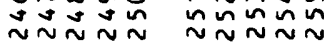

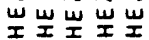

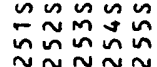

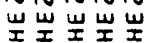

กูก กัก๊ $\sim$ 똪뽚

กำ 웅ㅇํㅇำ ww w w

๓ะณะล 이요 $\tilde{w} \tilde{w} \tilde{w} \tilde{w}$ 


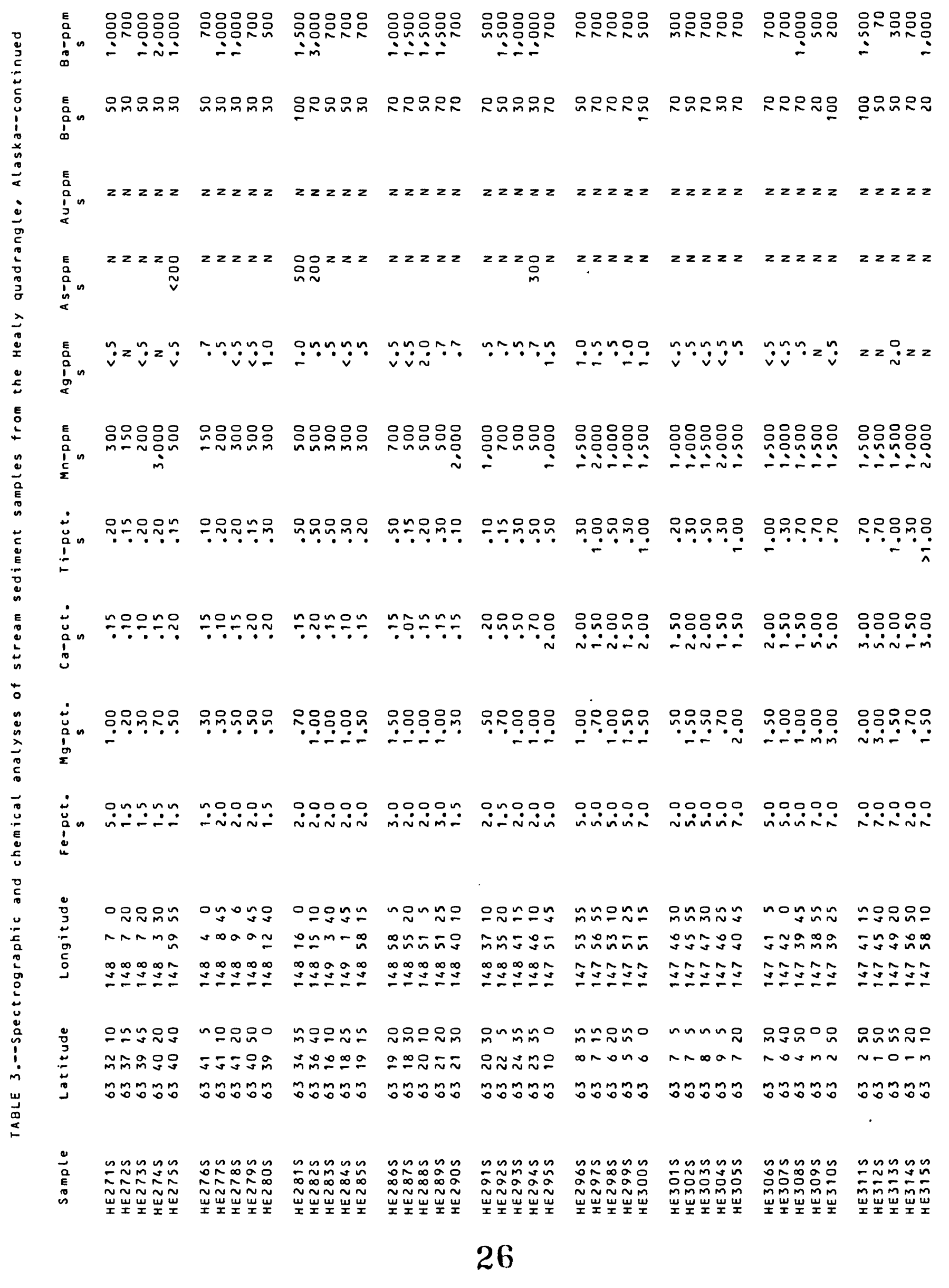




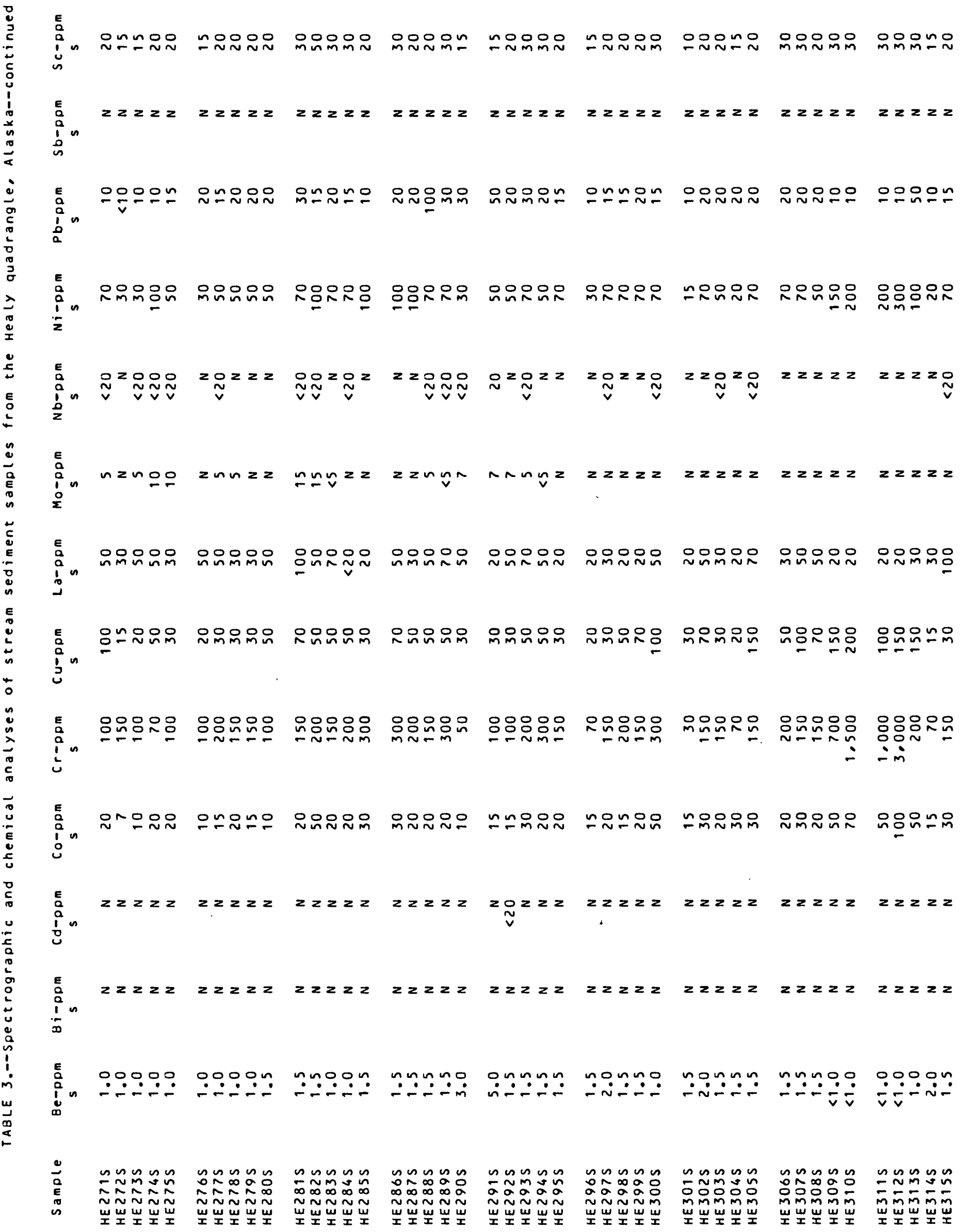




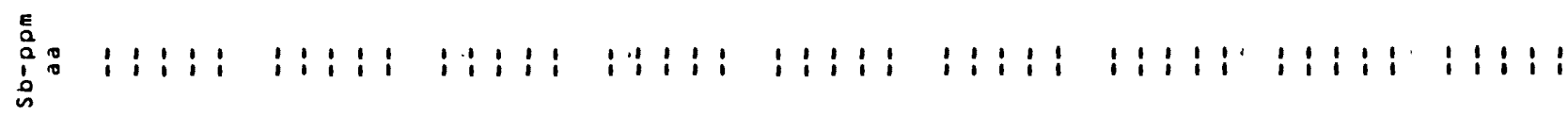

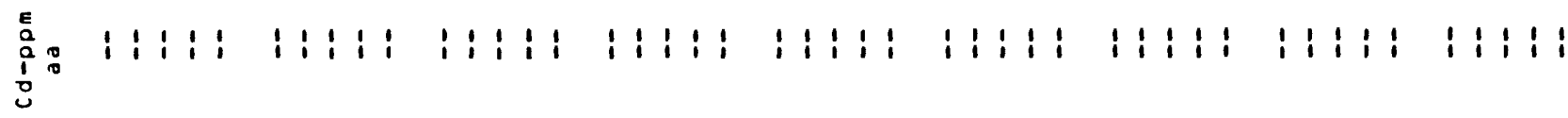

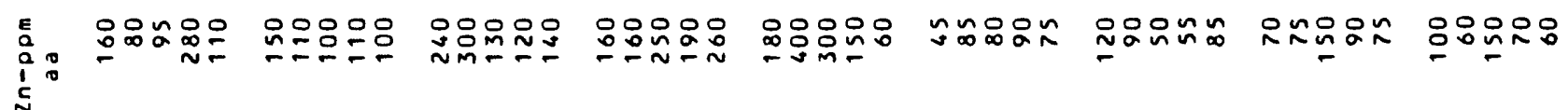
产。

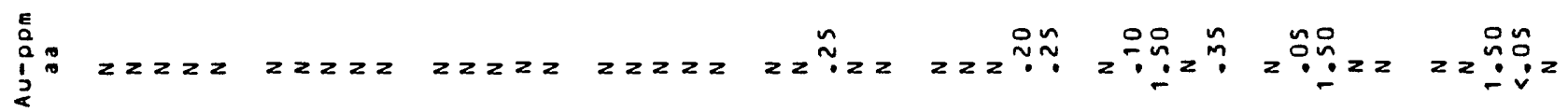
E $z z z z$ zzzz zzzzz zzzzz zzzzz zzzzy zzzzz zzzzz zzzzz

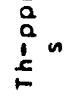

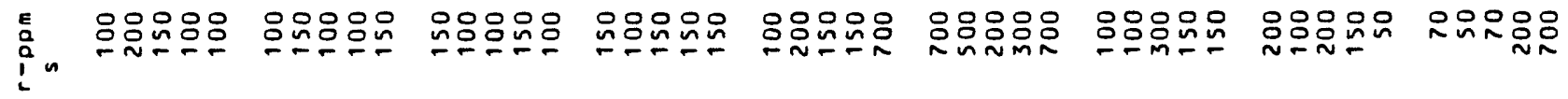

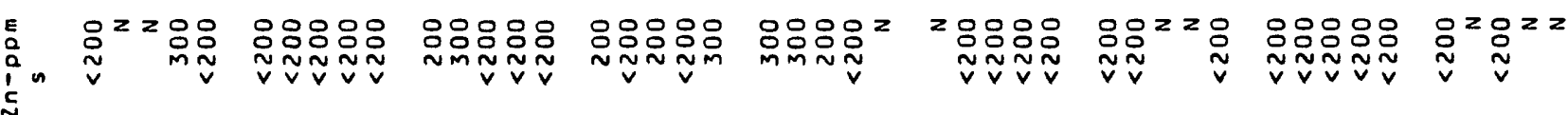

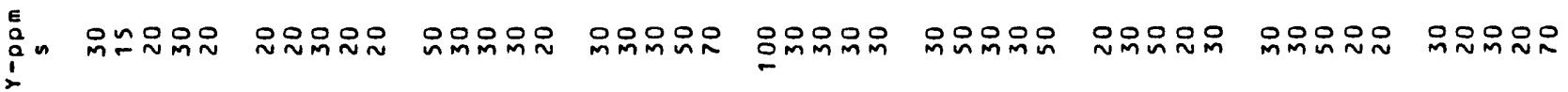

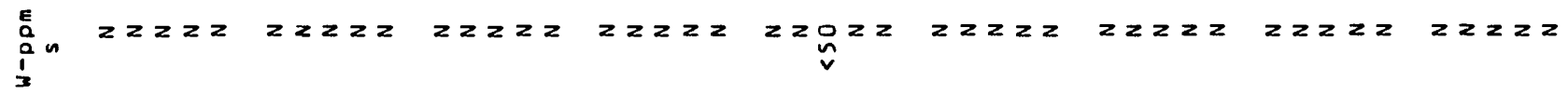

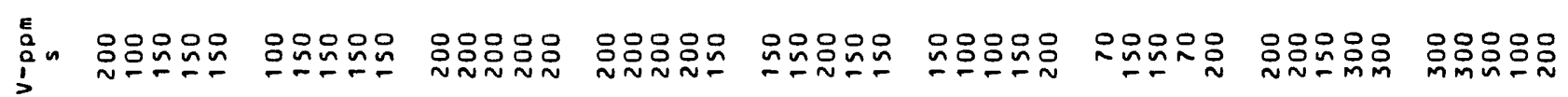

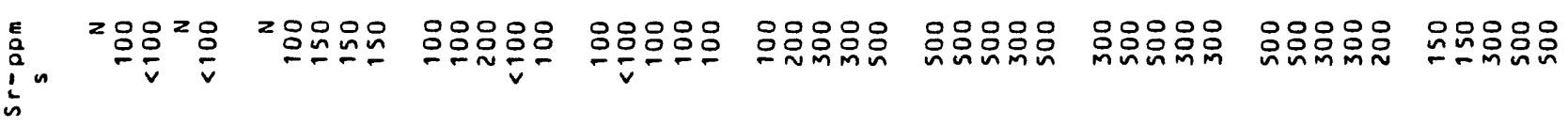
镸 c)

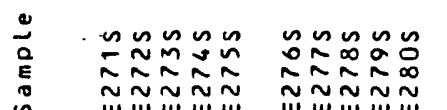

$\sim \sim n n n$ $\infty \infty_{\infty}^{\infty} \infty \infty_{\infty}^{\infty}$

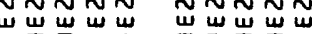

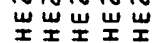

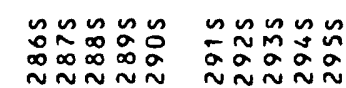

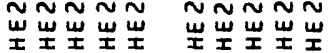

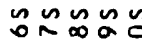
ํํำ

出出出出

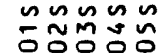
minmm w또

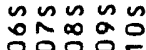
minm

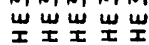

$\simeq \approx \tilde{\sim} \sim \sim$

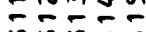
${ }_{w}^{M} M_{w}^{M} M M_{w}^{M}$ 


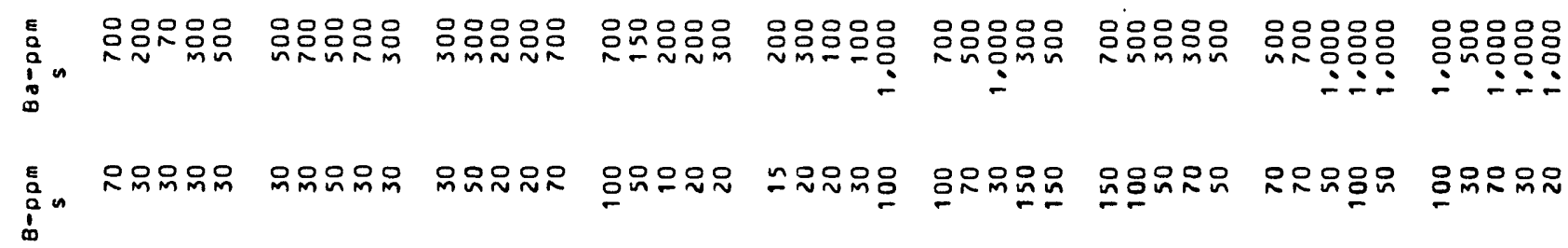

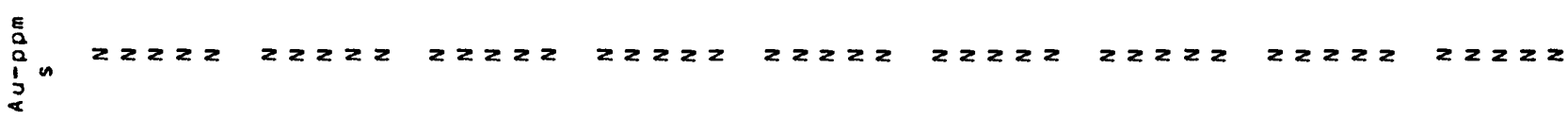

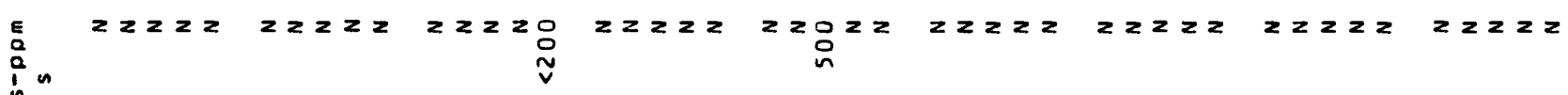

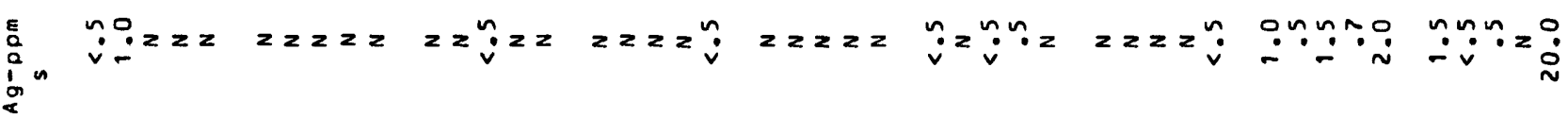

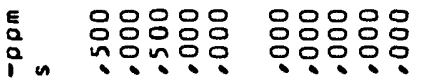

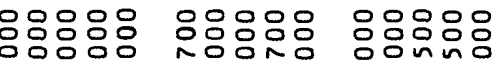

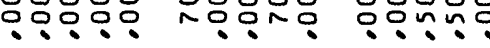
응음음 ำำㅁำ

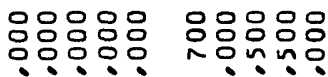
염웅욤

$$
\frac{1}{2}
$$
ンㅜ

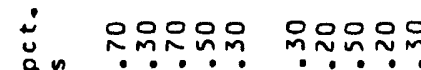

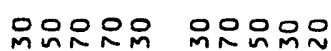

읐음욤

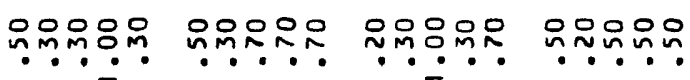
I

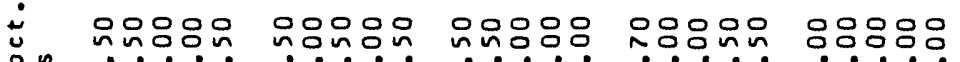

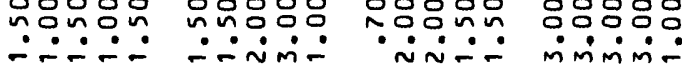

뭄유욤

00000

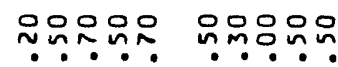
in $\therefore$ ini$\therefore \therefore-$ minimiinim

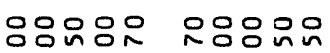

옹ํㅇㅇㅛ

요요

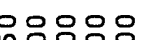
$\therefore \because \dot{\sim}$ نं $\dot{\sim} \dot{\sim} \dot{\sim}-$ - $\dot{\sim} \dot{0} \div$

웅요 ㅁopoo

옥응오오 on

$\stackrel{\dot{u}}{a} n$

00000

00000

00000

00000

0.000

0.00:0.

00000 $\because \because \div \div$ ning inivin

imimi

$0 \because 00 \%$ $\because \cdots$

은ำn 이잉

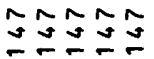
응ㅇㅇㅇㅇㅇㅇ mora 초ำ

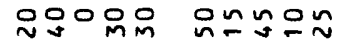
ニN 음ำ ำำ先 กำ

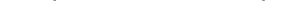

은ํㅇㅇㅇㅇ SnNon

MO MO

กํํํํํㅇ + MMNM

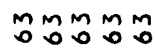

응으는

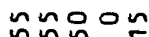
a onn nonon

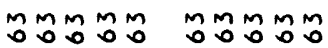

$\sim \sim \sim n n \tilde{n}$ $\bar{\sim} \tilde{N} \tilde{N}$ mw出出出

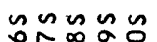

ññn NNNNM MMMḾn

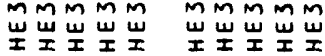
우룬

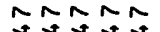

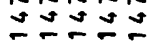

$\operatorname{nng} \operatorname{gon}^{2}$ n $\sim 00 \infty$ M. M.

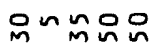
$\infty \simeq a=0$ mต้ำ noํㅇㅇํㅇ 으느음 móñ 은ㅇㅇㅇㅇㅛ EII món

经经을 으믕 món $\tilde{n} \sim \tilde{\infty} \sim \tilde{\infty}$

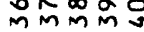
w出岕岕

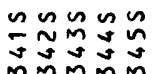

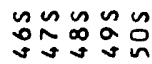

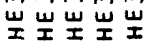
mMmmm

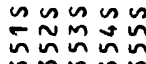
MMMMM

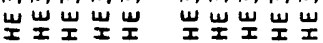

$\tilde{m} \sim \frac{\operatorname{mon}}{m}$ $\stackrel{\infty}{\sim} \sim-\infty \sim$

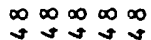
ษேニュン 


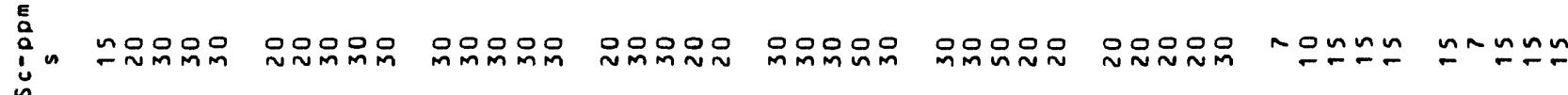

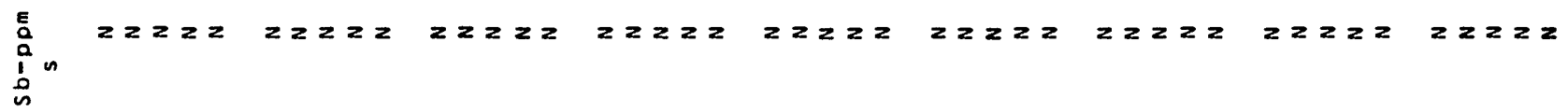

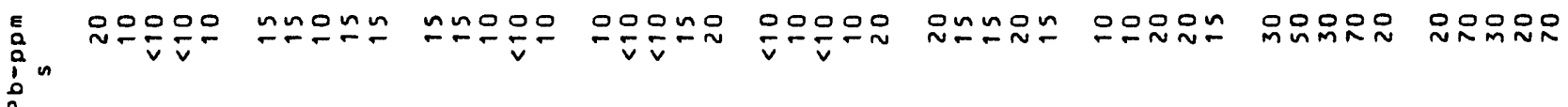

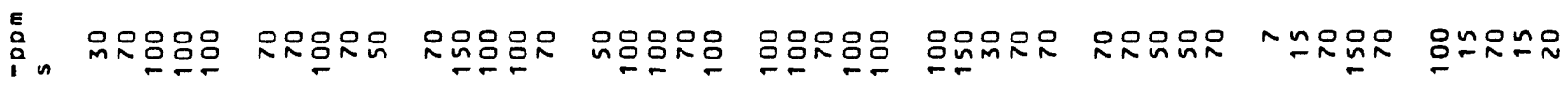

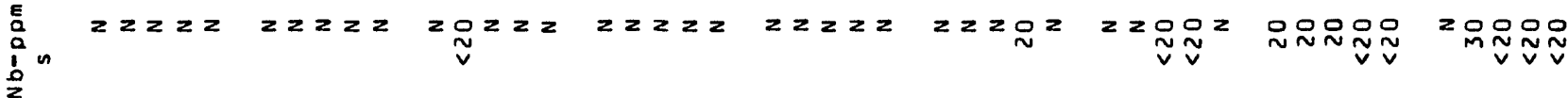
竞

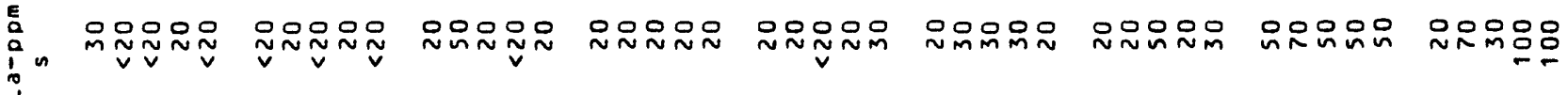

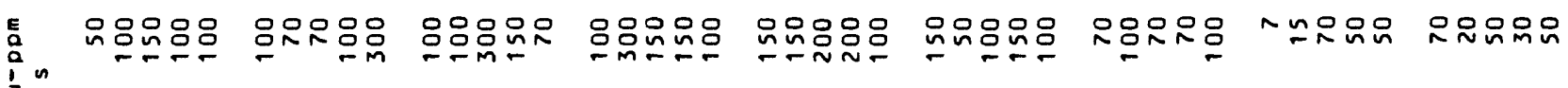
క

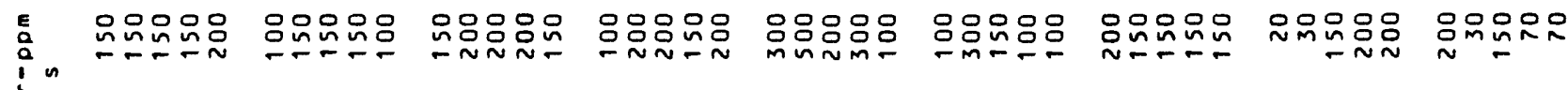

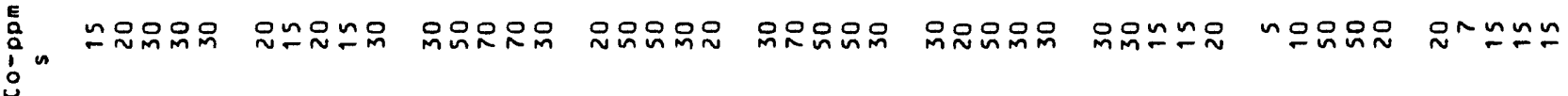
E

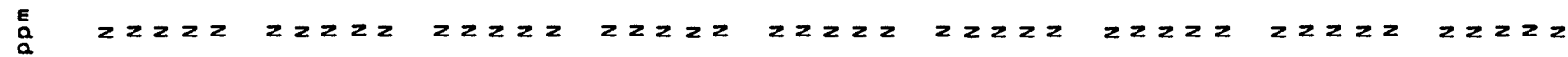
$\frac{1}{\infty}$

in

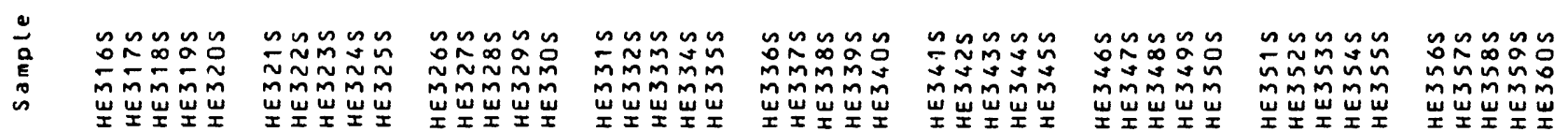


镸

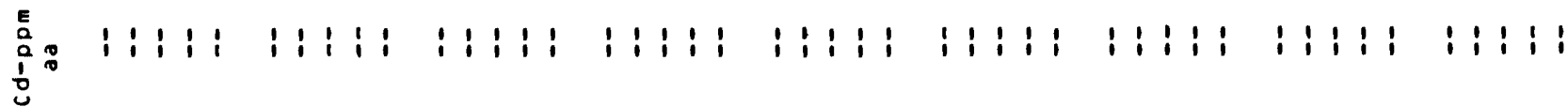

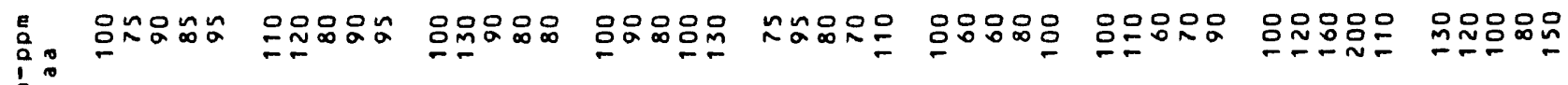

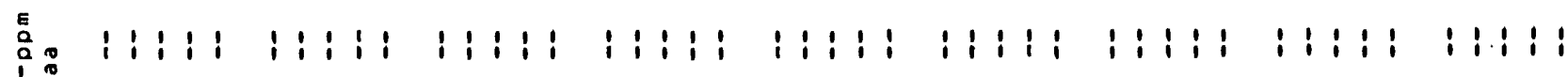

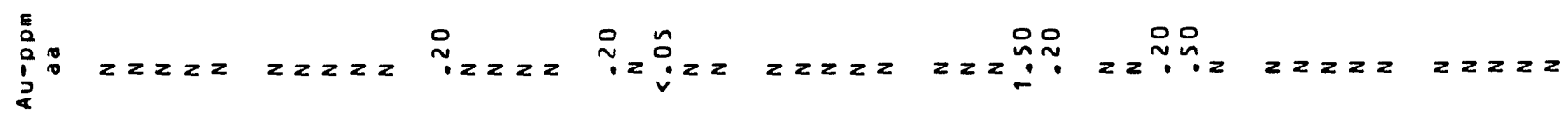

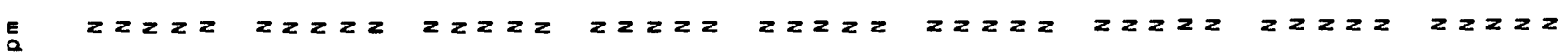
$\sum_{1}^{2}$

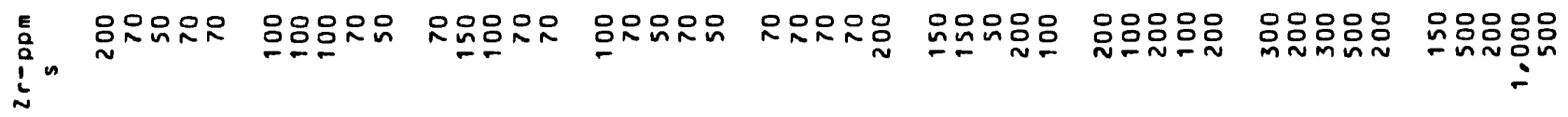

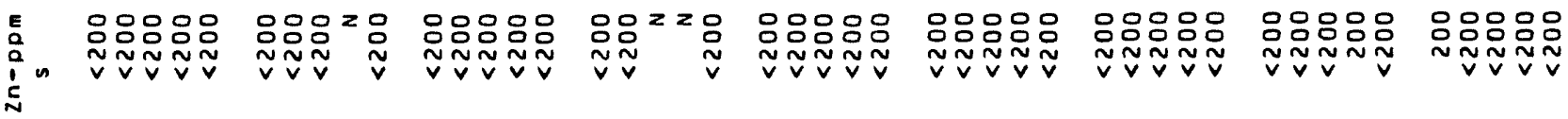

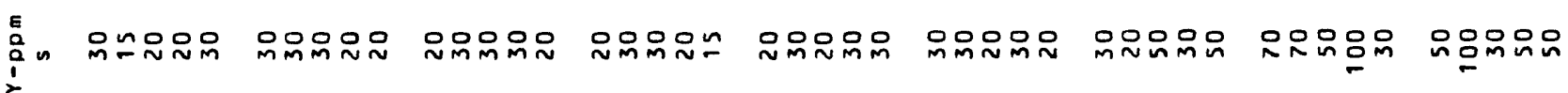

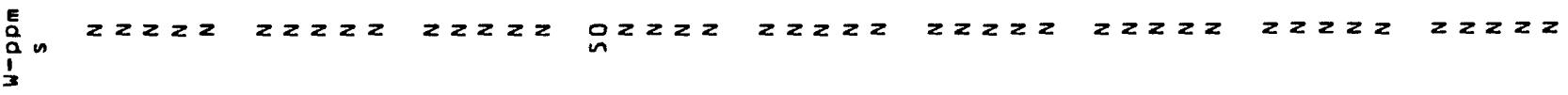

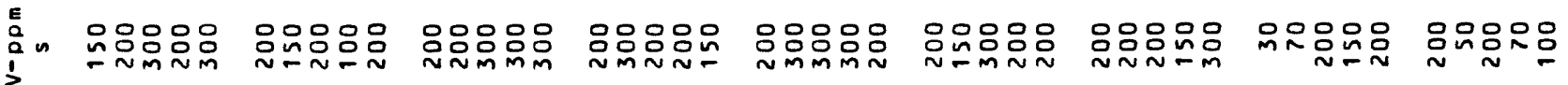

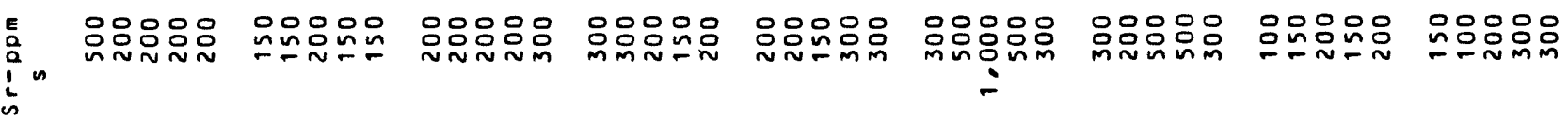
E

ธ⿻一𠃋十 mpmm món

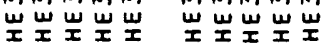

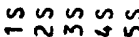

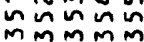

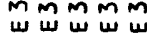

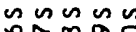

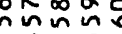

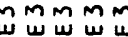

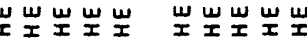




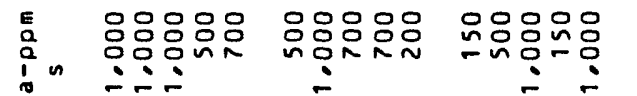

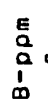

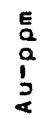

$E$
$a$
$\vdots$
$\vdots$
$a$

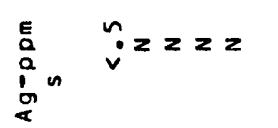
$\tilde{v} \tilde{v}^{n} \tilde{v} \tilde{v}$ $\dddot{v} \because \mathfrak{v} \dot{v} \dot{v}$

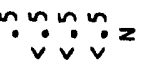

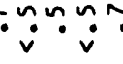

\section{E 응용응}

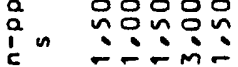
응응응음 운nำ ํㅠㄴㄷㄴ

옹옹응 는ํํㅇํㅇ 这

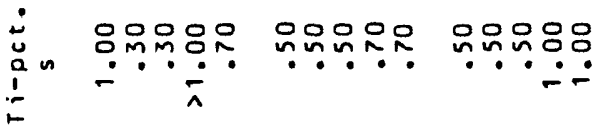
은우눈운오 옹응용요 응음음웅 음음웅영 응응요윰 응웅용ㅁㅁ

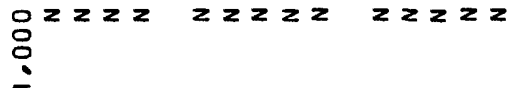

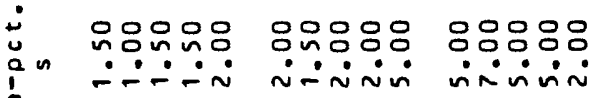
vinivin

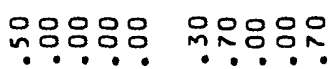
응웅응 - ininiv

입용ㅇㅁㅇㅛ

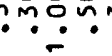

뭄으무ํ요.

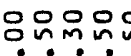

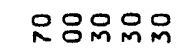
$\therefore$

\section{0}

뭄ํㅜ웅

웅ㅇㅇ $\because \frac{1}{0}$ 욲용ㅇㅇ응 כ

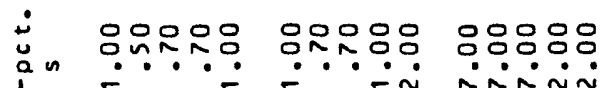
응응음 음응응으 iññm nimi-

음웅요음 $\dot{m} \dot{\sim} \dot{\sim}$

응응응ㅇㅇㅇ imi-im

옥응요음 -min-

응용ㅇㅁㅇ -inini-

00000

00000

00000

00000

00000

00000 à inininis vinun oón ingin ññn
00000 수숭
00000 ininis
음옹응 는요웅
00000 vinion

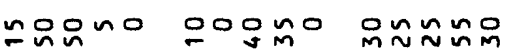
กNํำ

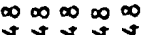
anor

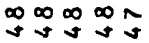
$\simeq \simeq \infty \infty$

$\hat{y} \hat{y} \hat{y} \hat{y}$

エேニニ

\section{ginno}

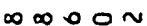

ทีกับำํำ

mmoso

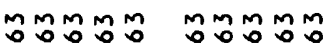

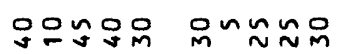

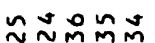

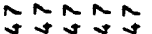

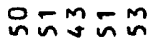

agaga

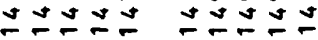

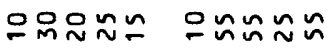

oOomo o-moo

mMmmm ตุมूm
กำ的品

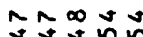

aga シンンンン

ทํำニ品

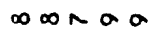

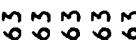

으으ำ음

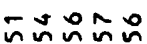
araa gaga

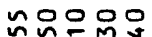
$\infty \infty \sim \sim$

mmmmm
ㅁํํㅁำ 蛅总品=

araa 正壬士 そูำกำ ommin

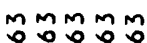

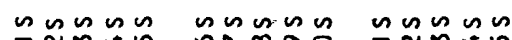

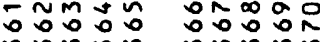

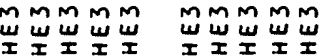
ANAN MMMmM пिMMm

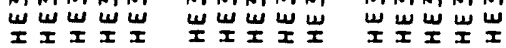

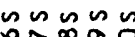
$\infty \infty \infty \infty \infty$ $M M M M M$

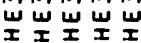

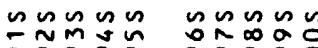
åmã ååo

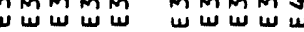
岌岌岌岗岌

nnun Боำ

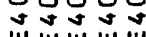
${ }_{i=1}$ 


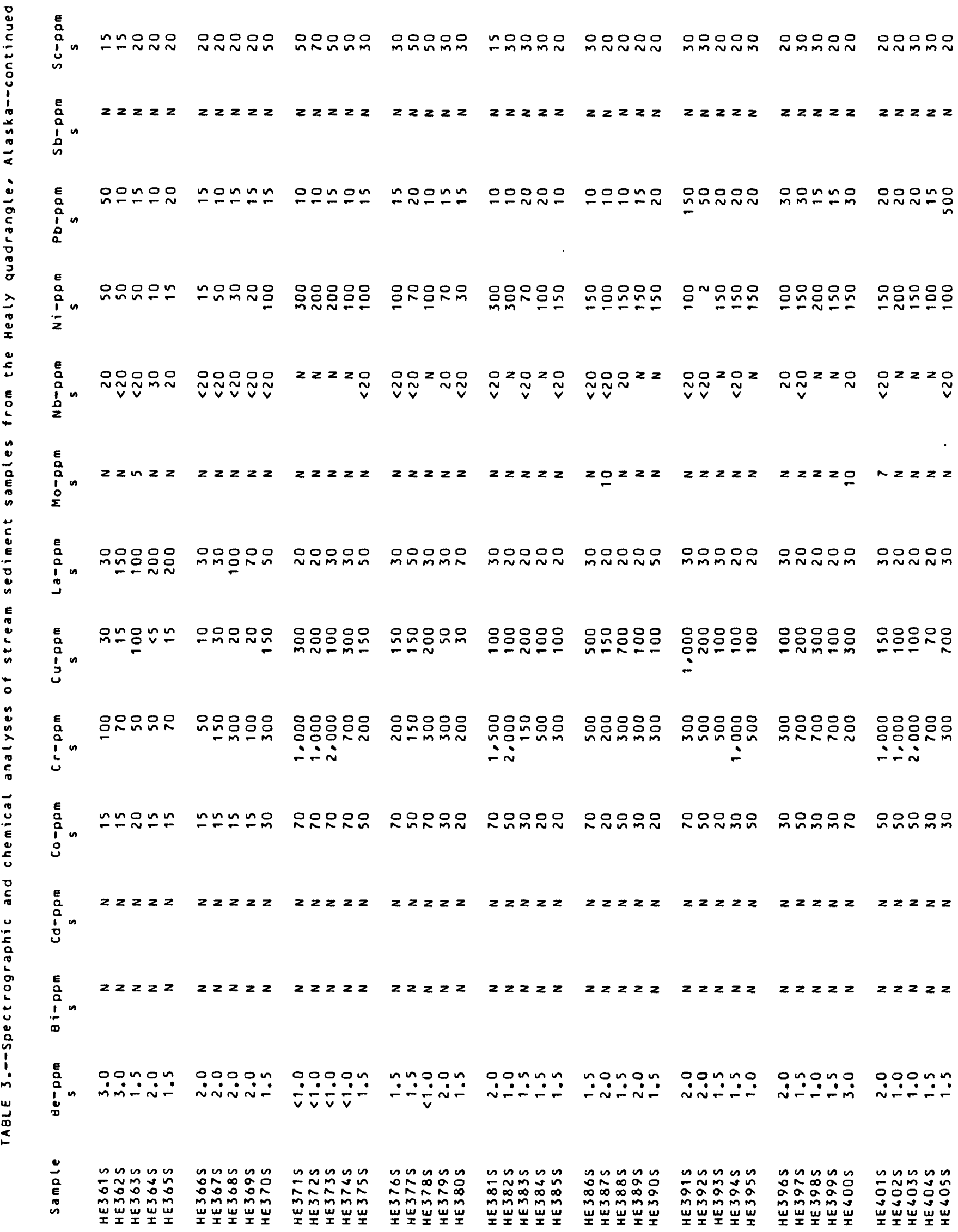




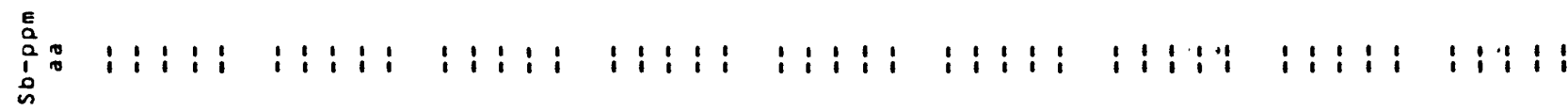

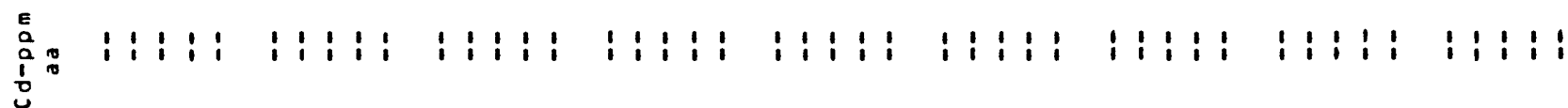

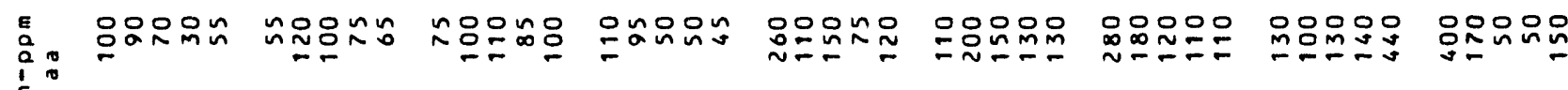
$\stackrel{1}{n}$

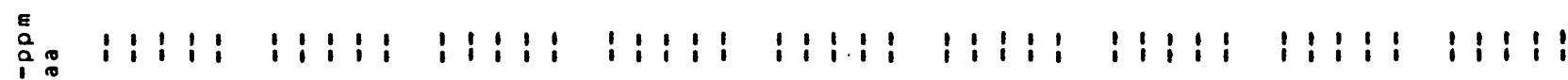

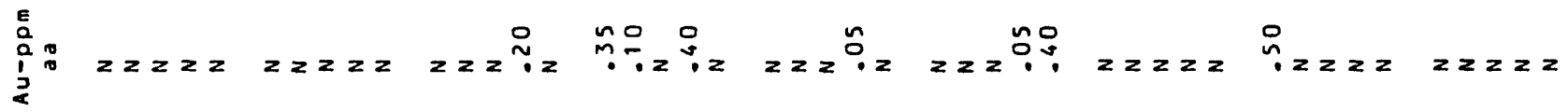

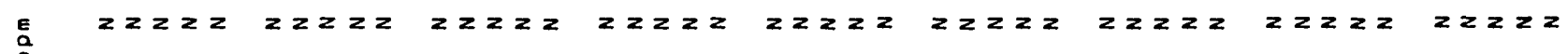
$i^{2}$

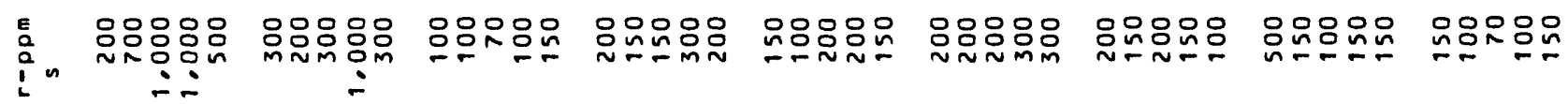

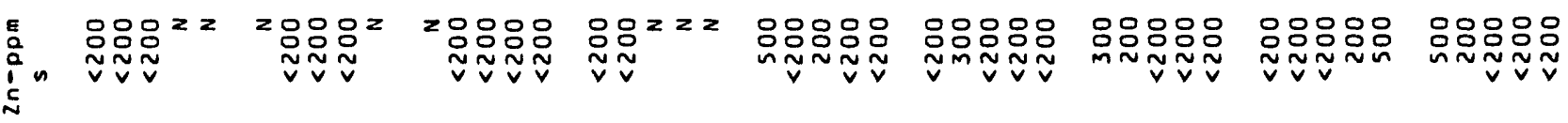

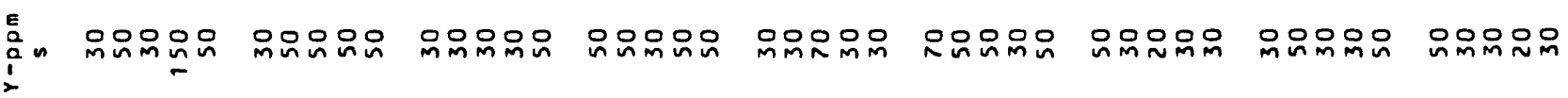

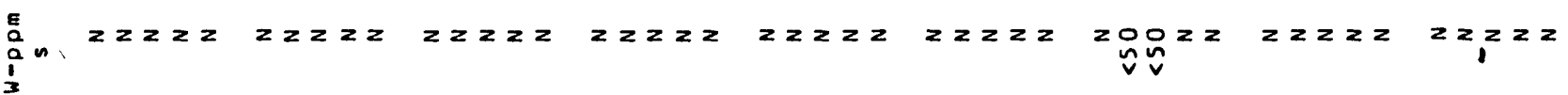

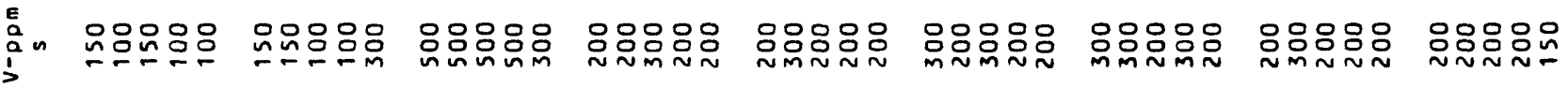

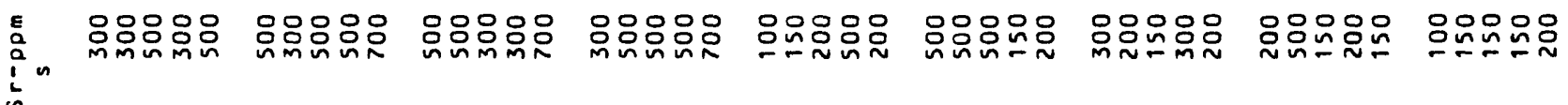

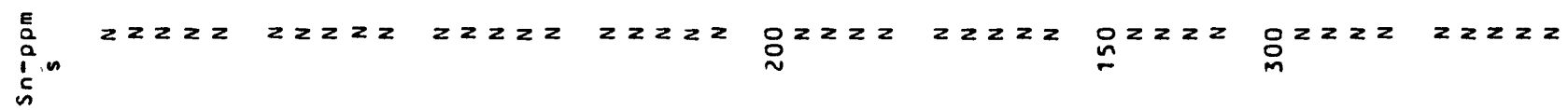

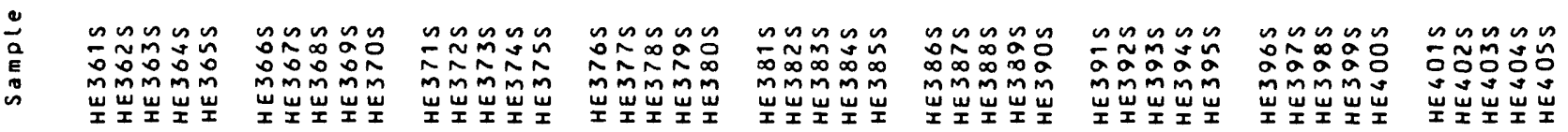




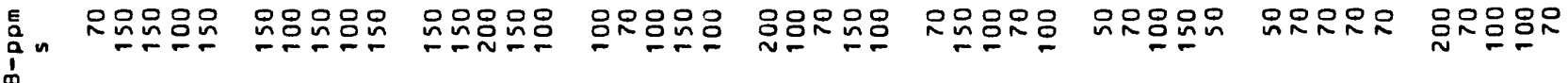

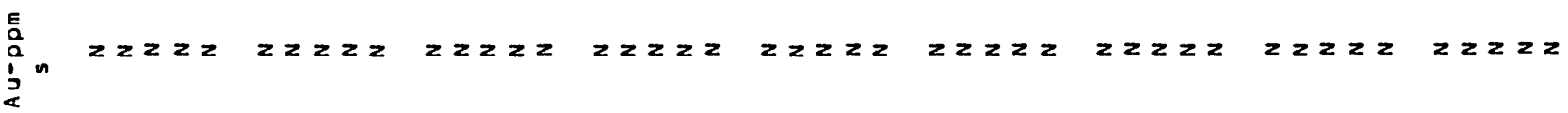
$\frac{\mathrm{E}}{\mathrm{a}}$

$z z z z z z z z 2 z z z$ $z \geq z z 2$ $z z z z$ $z \geq z \geq 2$

$z z z z z$

$z z z z z z z z z$ $i_{\text {in }}^{\infty}$

$E$
0
0
0
0

ดก กัด in $n$

$\because n z^{n}$

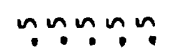

ñvive

$z=\cong$

$z=\because z \stackrel{n}{i} \dot{v} \dot{v} z n z$

$\because n \backsim n n$

$\because \because 0$ :

焉

品品品品 总品品品品

品㖞品品员

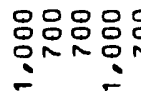

옹옹ㅇㅇㅇ

\section{,}

움음웃윰연

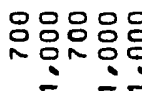

옷웃웃뭉유

웃움옹욤욤 $\dot{\vdots}$
$i_{n}$
$\vdots$
$i$

00000

웅ㅇㅁㅇㅛ

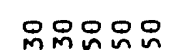

웃욤용요

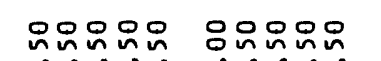

웁묭ㅁㅇㅇㅛ

음응요

웅음용요

$\dot{a}_{\substack{0 \\ 0}}^{0}$

음응유

00000

$\dot{\sim} \dot{m} \cdot$.

$\therefore \dot{n} \dot{n}$

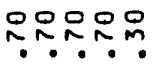

$\therefore$

옴ํํํํㄴ

운유옹으.

운음음욤

운뭉ㅇ

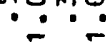

$\therefore$

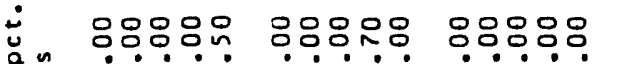

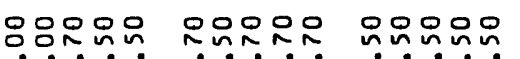

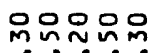

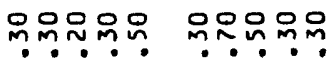

垔

$\because \because \dot{\sim} \dot{\text { m. }}$

น-n் $\because \dot{\sim} \div$

$\therefore$

ă

00000

00000

00000

0.0000

00000

00000

$\because \because \because 9 n$

$\because \because \because 90$

0.000 :<smiles>C1CCCC1</smiles>

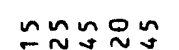

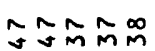

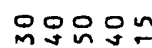

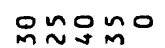

a

gaga

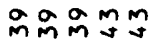

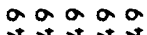

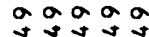

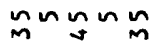

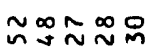

웅응

ตับก๊

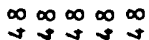

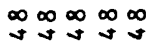

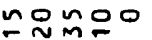

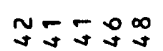

는ํㅇㅇㅇㅇㅝ

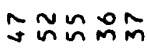

$\infty \infty \infty \infty$

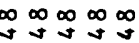

○品的年

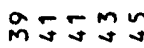

$\infty \infty \infty \infty \infty$

さニささす

レンニンニ

oำn몽

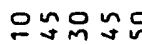

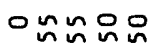

ํํํํำ的品

웅ํำno

$=0 \infty \infty n$

こニニニニ

ニさささ

กละกำ

드용워

คำติำ

ำำํำ

ติำmm

ติำตำ

ํㅡㅁำำ

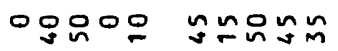

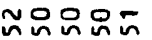

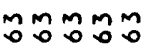

顽品动品

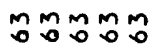

ํํำณ只

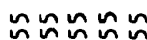

mommon

ก융요

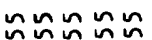

ติำณำ

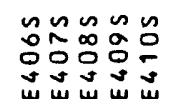

岂岕岕岕岕
๓กษณ

ำำำ

岂岂岂崲

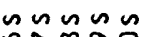

ำํำㅇำ

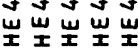

n⿻上丨 $\bar{\sim} \sim \sim \sim ⿻$ 岂岂岂岂 $\sim \sim n \sim n$ $\stackrel{\sim}{\sim} \sim \underset{\sim}{\infty} \stackrel{0}{\sim}$ 岂岂岕岕岕 $\sim \sim \sim n n$ 的鱼的品

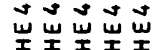

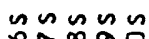
ํㅗํํํํ요 岂岂岂岂岂 $\sim \sim n \sim n$ 于N祡

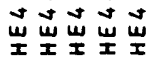

กะก

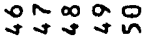

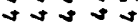

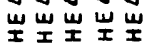




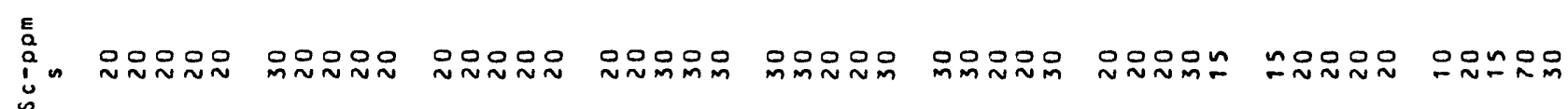

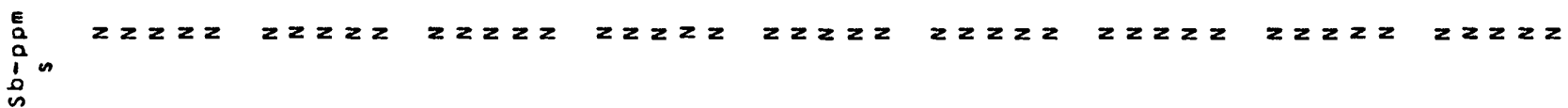

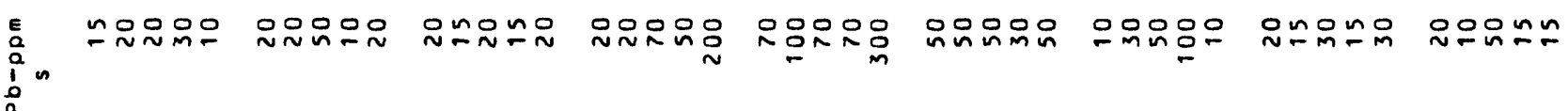

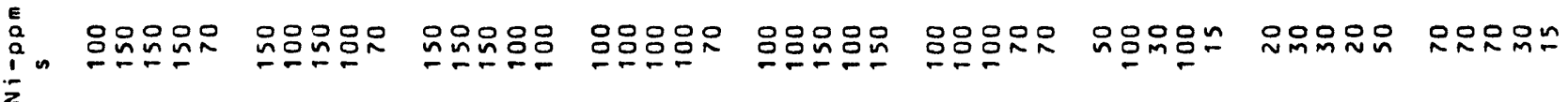

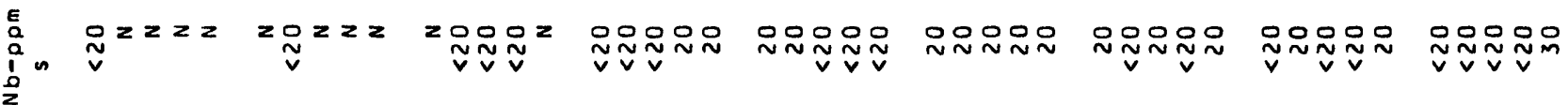
!

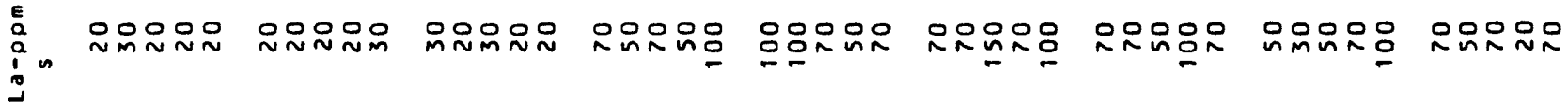

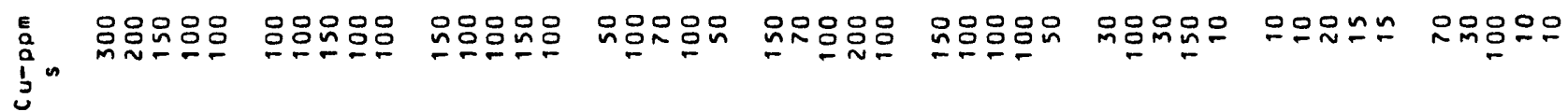

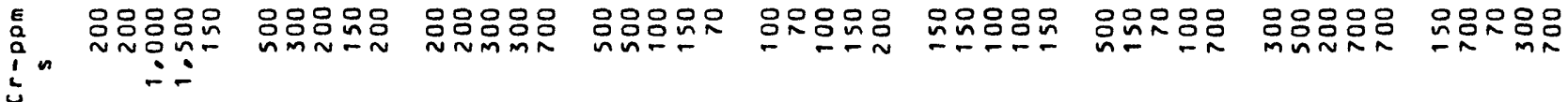

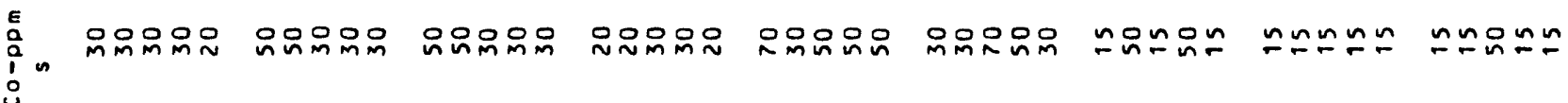
E
O.
in

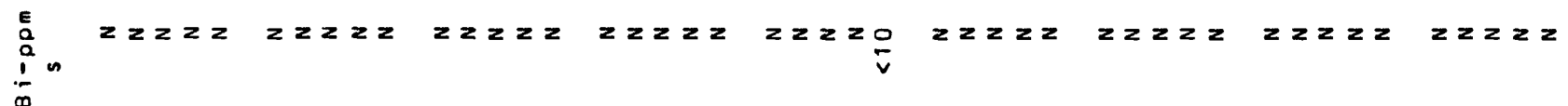
Í

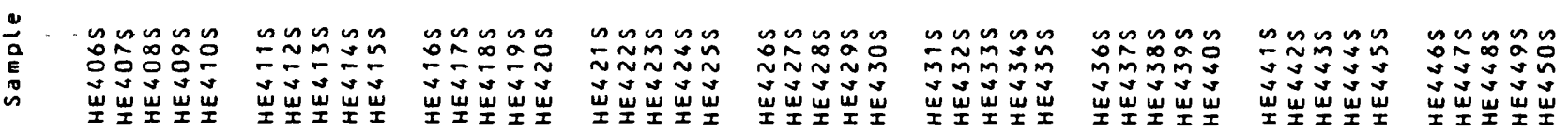




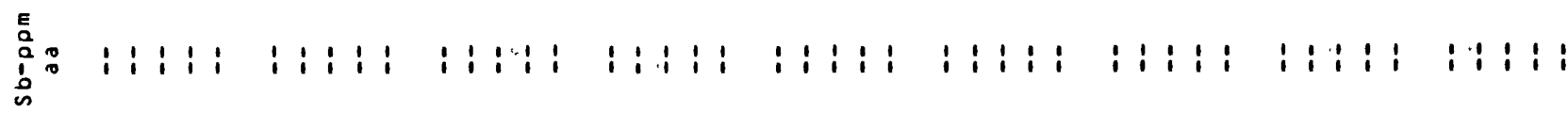

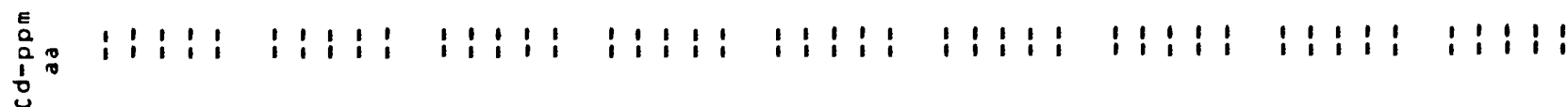

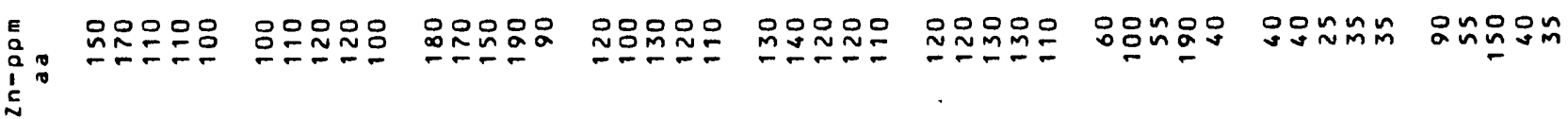

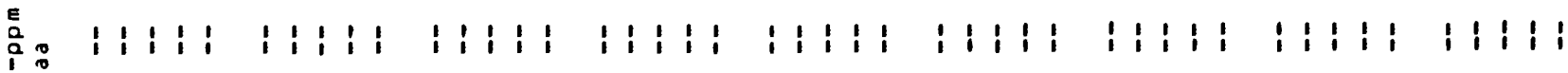
i

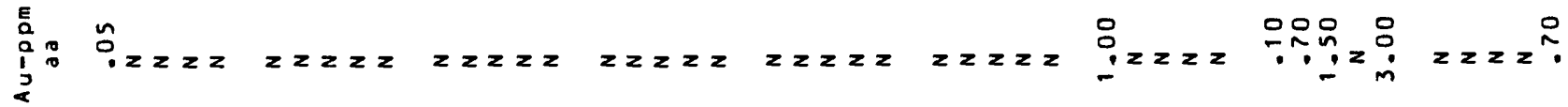

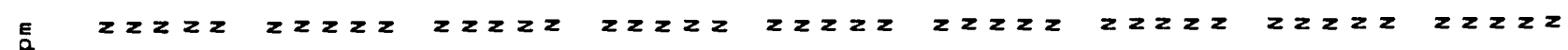
$i^{i}$

$\stackrel{\text { E }}{\stackrel{a}{a}}$

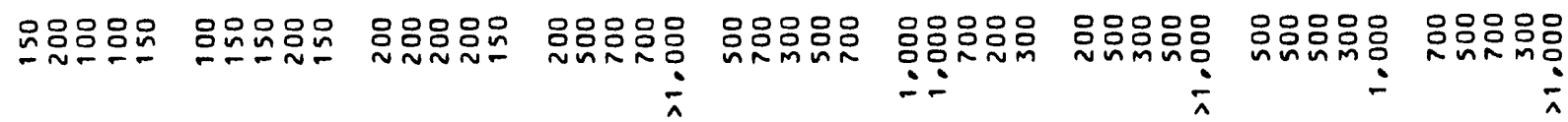

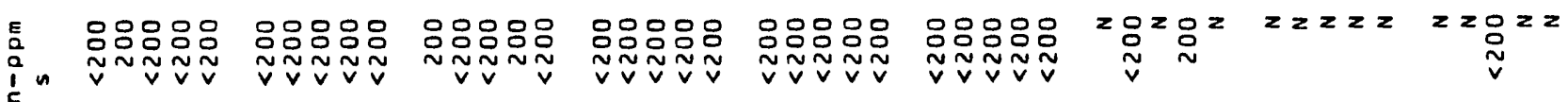

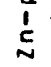

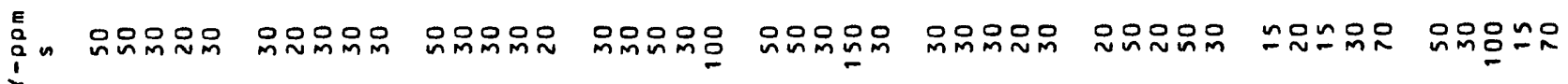
镸

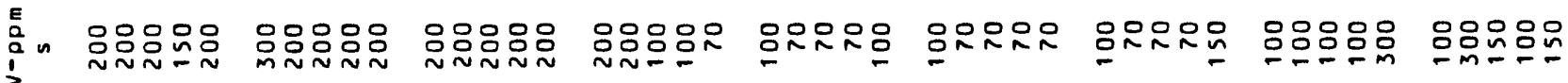

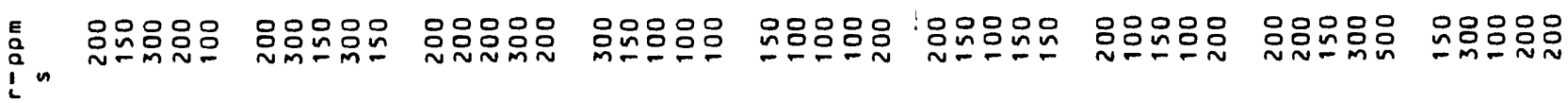

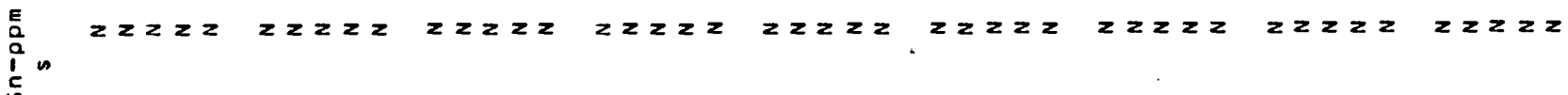
s

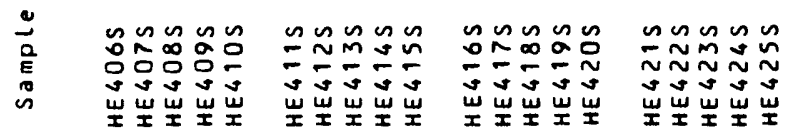

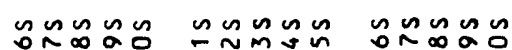

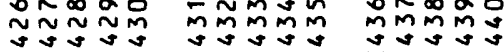

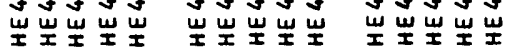

$\operatorname{snn} n \pi n n \infty n$ ajuzaz a

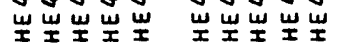




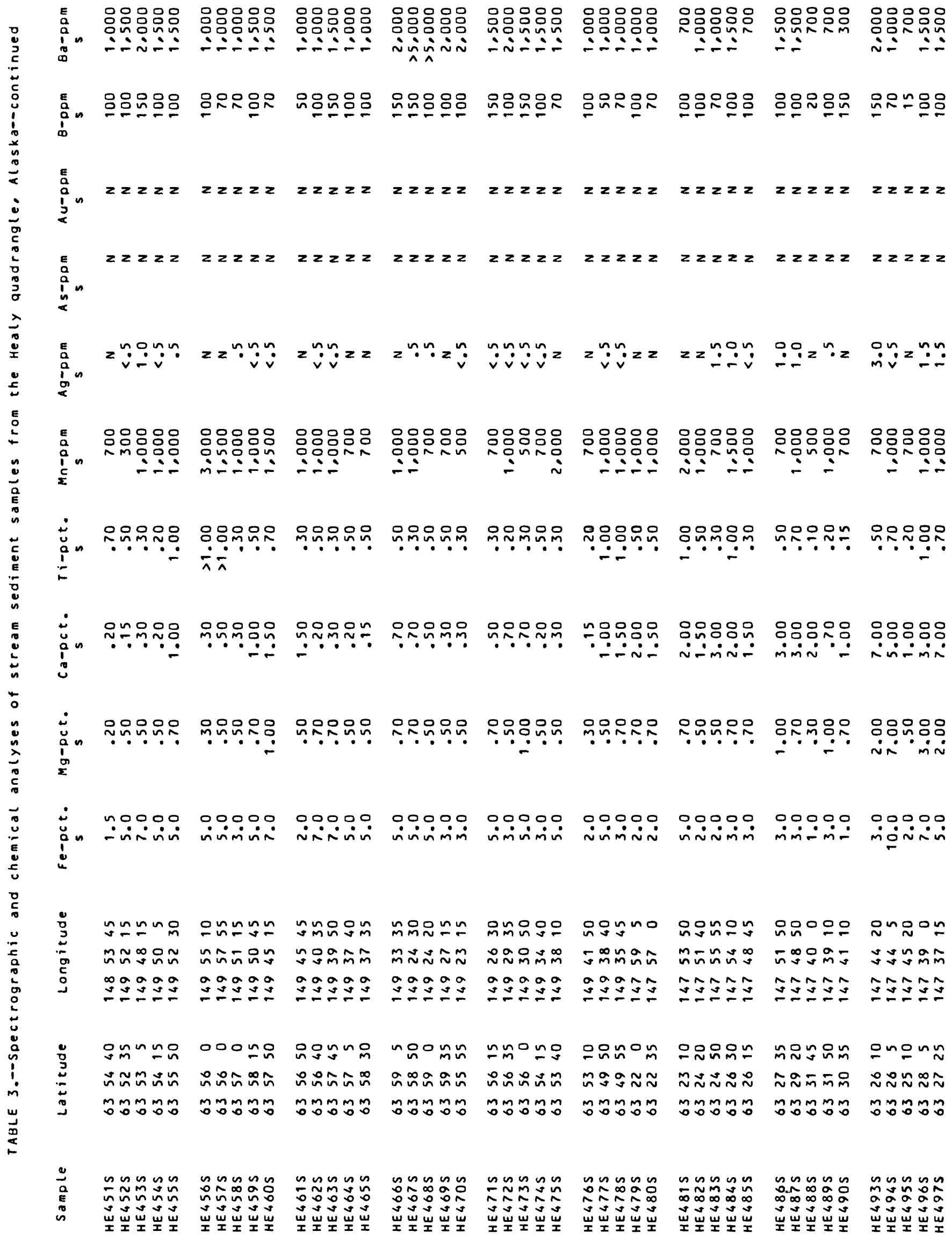




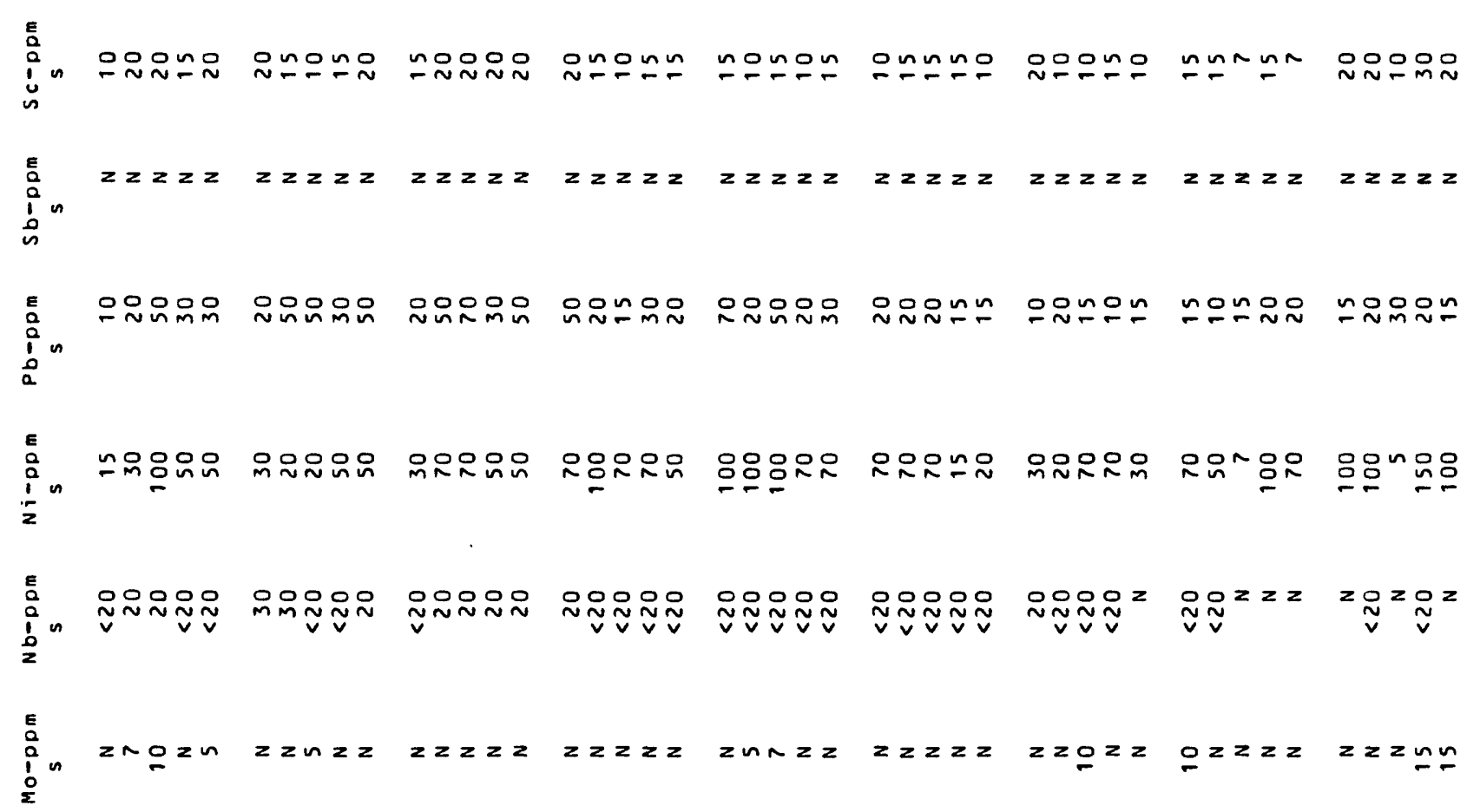

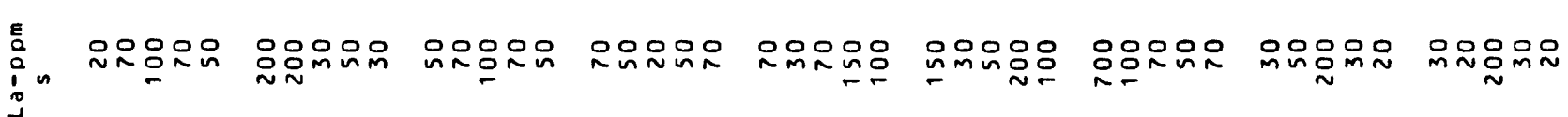

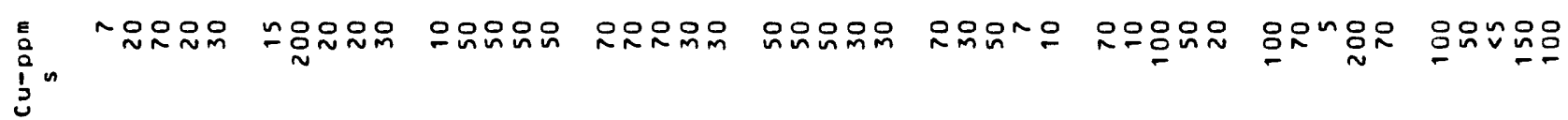

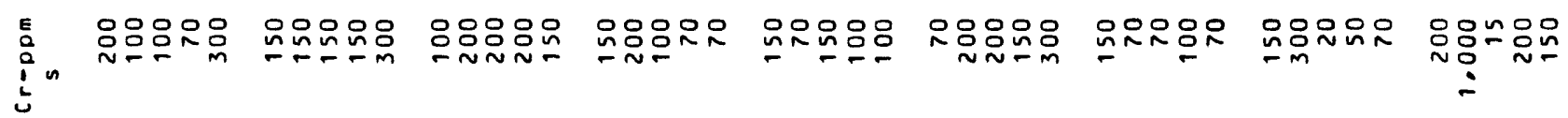

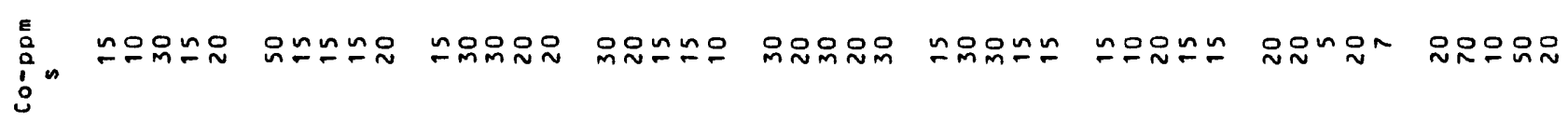

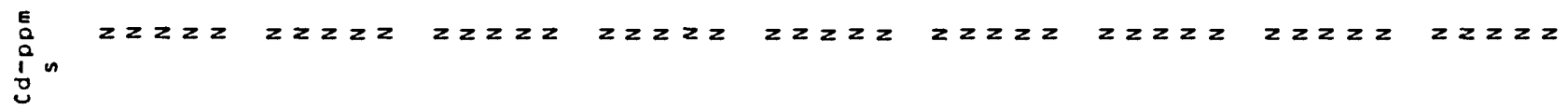

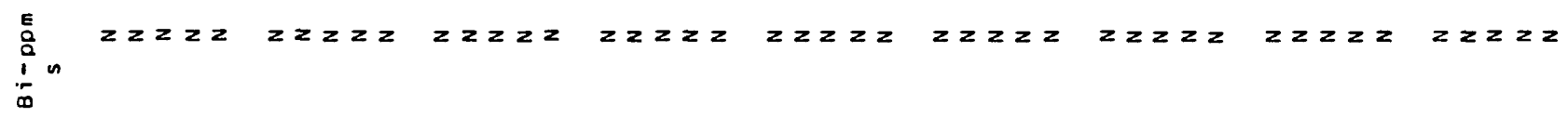

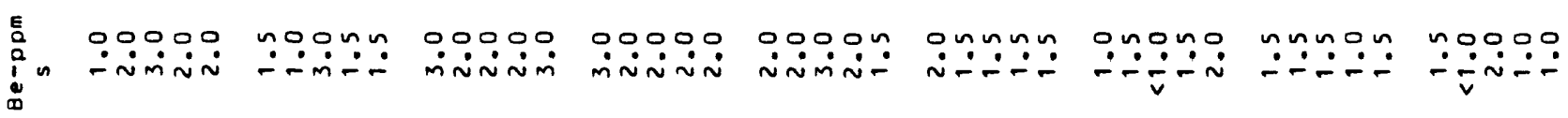

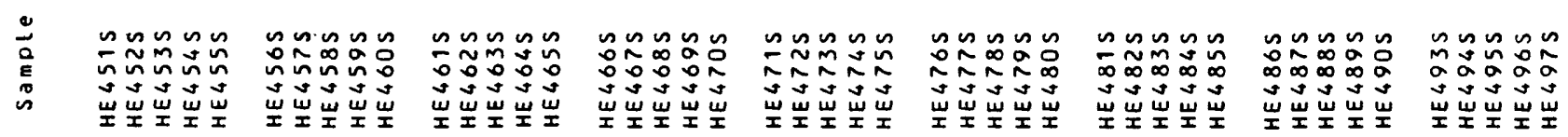




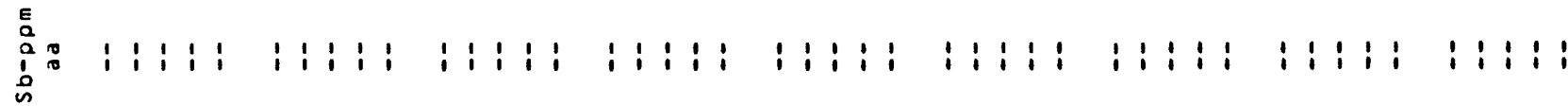

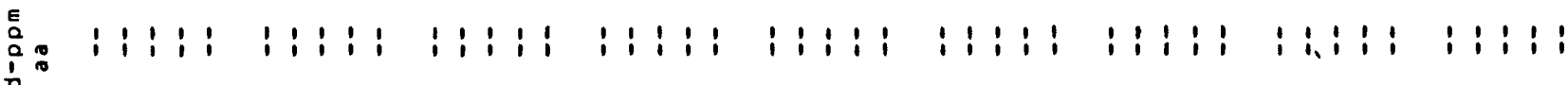

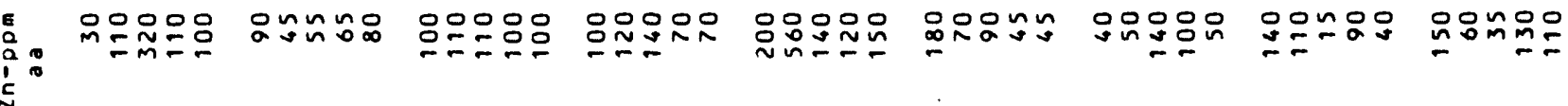
$\stackrel{n}{c}$

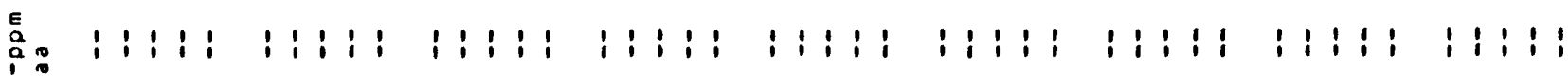
否

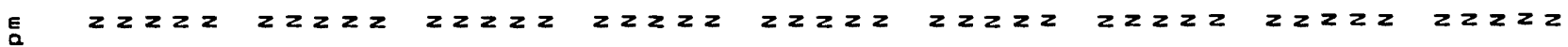
$i_{i=1}^{a}$ $\stackrel{n}{a}$

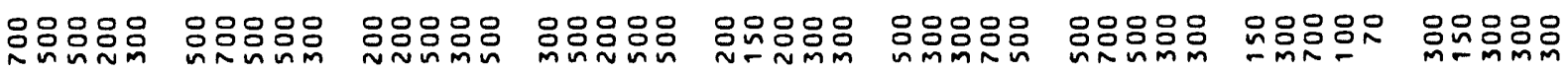

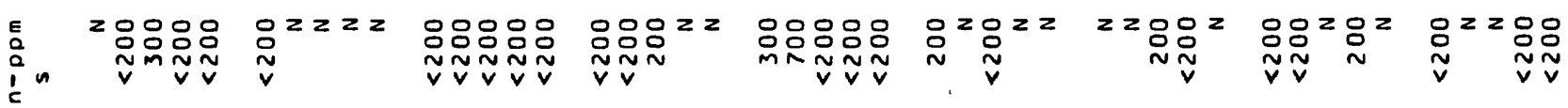

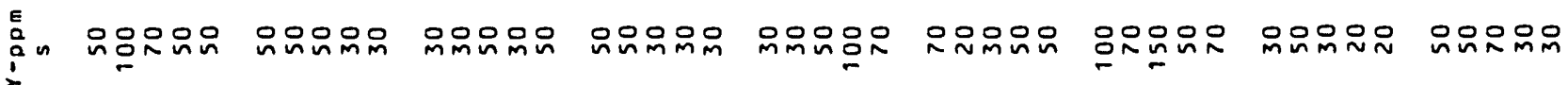
E

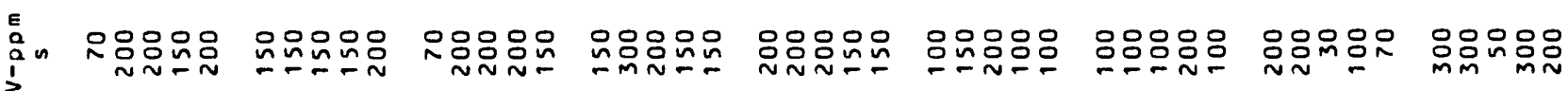

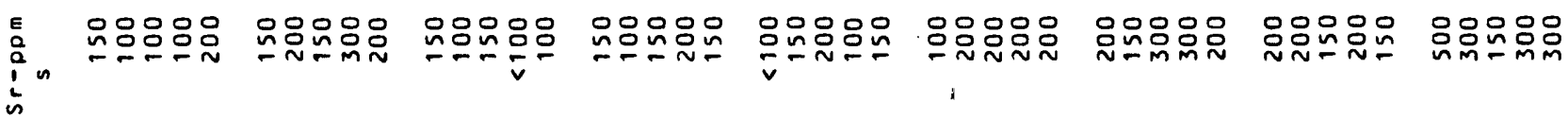
E

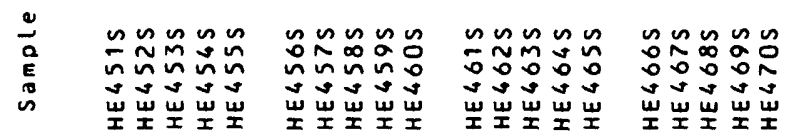

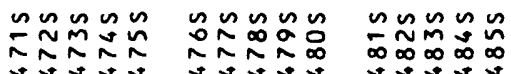

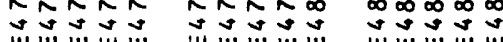

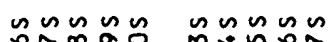
$\infty \infty \infty 00$ a a a

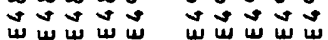




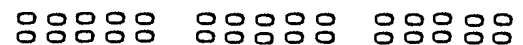

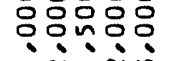

웅음음

숨ํํ옹

응으음

우느

옷ㅇㅁ웅음

음응응ㅇ

응ㅇㅇ

웅ㅇํㅇㅇㅇㅇ

웃응ㅇㅇㅇㅁ

운

응응응응으

ํํํำ

总n

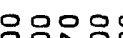

응ㅇㅁㅇㅜ

은웅응

옷으오소

옹옹ㅇㅁ

웃응우옹

옷오온

은으믄믐음

온융ㅇㅇ응ㅇ

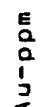

$z 2 z 2 z$

$z z z z$

22222

$z \geq 2 z$

$z 2 z 2 z$

$z z z z z$

$2 z 2 z$

$222 z$

$z 2 z z 2$

in

$z 2 z 2$

$2 \geq 2 z 2$

$z \geq z z 2$

$z z 2 z z$

$z z z z z$

$z 2 z 2 z$

2222

$z 2 z 2$

$2222 z$

흠

$\because \because z \stackrel{n}{\because}$

$\because ? ?$

$z z z z$

$\because z 2 z ?$

$z 2 z 2 z$

$2222 z$

$z z z z$

2

$2 z 2 z \quad 222 \dddot{n}_{v}$

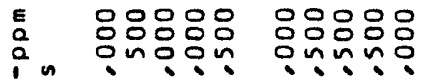

용요

ㅇํำำ

옴웅영응음

의옹

응옹응ㅇㅇㅇㅇㅇ

는ํํㅇㅇㅁㅇ

응응ㅇㅇㅇㅇㅇㅇ웅

는문

옹응응음

응ㅇㅇㅇㅇㅇㅇㅁㅇ

응응응음

은웅무

음응응음응

momin m- ñin

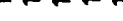

:- :

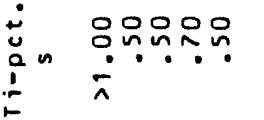

응응융으 옹웃응응

온응요우

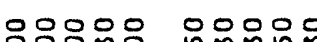

옹ㅇㅇㅇㅇㅇㅇㅡ

응옹은으ㄴㅗㅡ

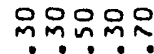

:

이잉

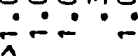

inm.?

$\because \div$

$-\frac{1}{\wedge}$

i

niminin

iñin

$\therefore \because \therefore$

บำ.

옹으는응

옹요은

o

은응요

웅ㅇㅇㅛ

온은요은

$\dot{\vdots}$
$\ddot{a} n$
$\vdots$
$\vdots$

응음응응

응옹ㅇㅇ응 응옹요응

은응응유용

옹응응웅ㅇㅇ

은은유눈

윰우옹은

옹은으는

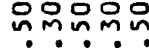

0000000000

00000

00000

00000

00000

00000

0.000

00000

ă n

iminivi

niminis

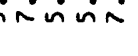

ヘिंmín

in $\min$

minimi

iminimin

जinminim

जiminis

nogon nonñ nnoggn

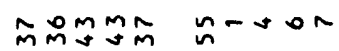

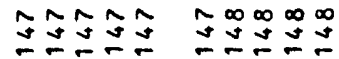

a moNO

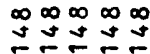

m〜⿻ำ

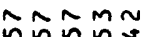

으은

a mm $m \infty$

옹ํ요

퓸ำ

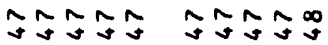

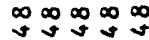

O

$\Sigma \simeq \simeq \simeq \sim$

mnn $n$ 은

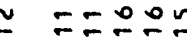

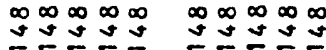

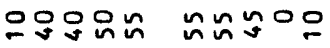

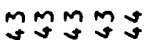

ป⿻ำง

mos $\begin{array}{ccc}m & m & m\end{array}$

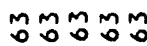

은으욤

20ㅇㅇㅇ

móñ
งก๊นกำ $\underline{m \sim \sim ⿻ 上}$

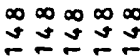

은ํํํ의 gơููป

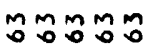

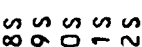

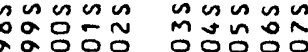

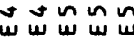

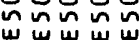

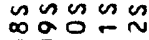

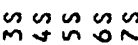

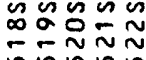

m n $\sim \sim \sim \sim \sim$

nn $n$ nn

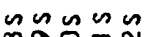

mmmmm

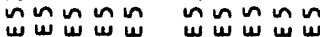

w出出出w

แnนnู mang? nunun

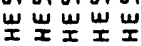




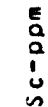

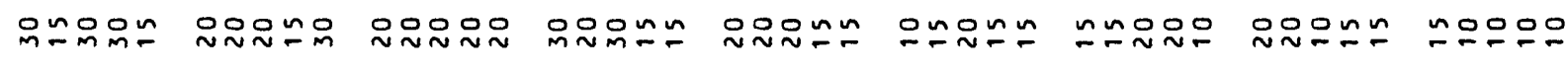

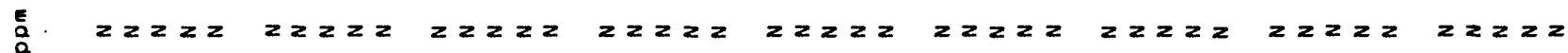
isn

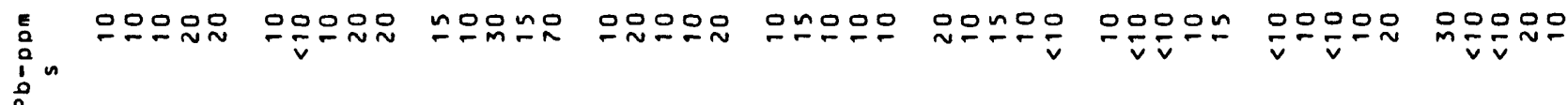

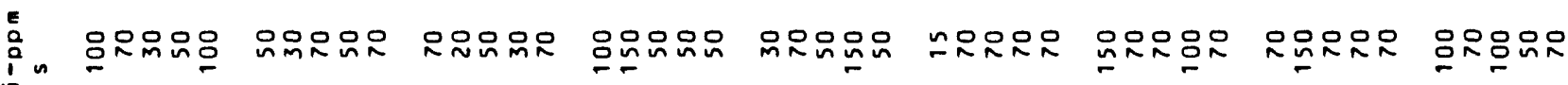
$\frac{r}{2}$

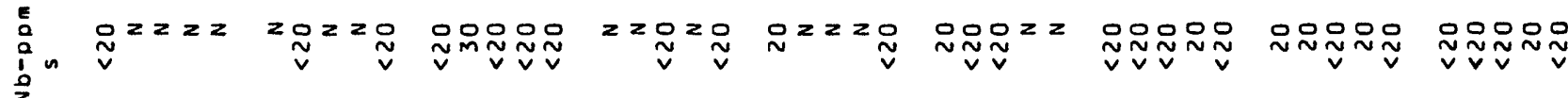

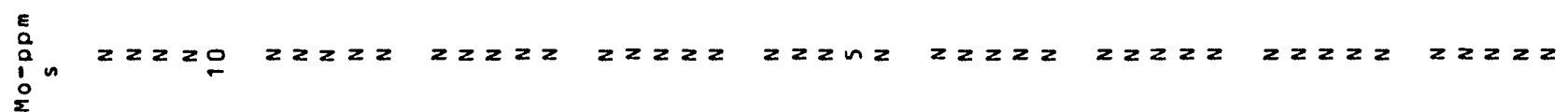

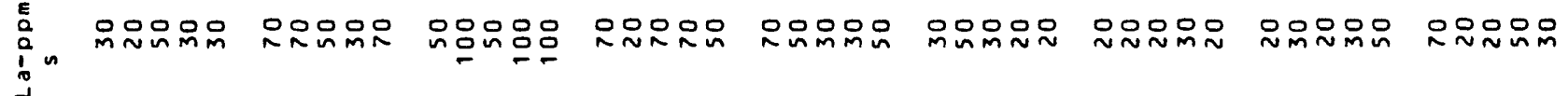

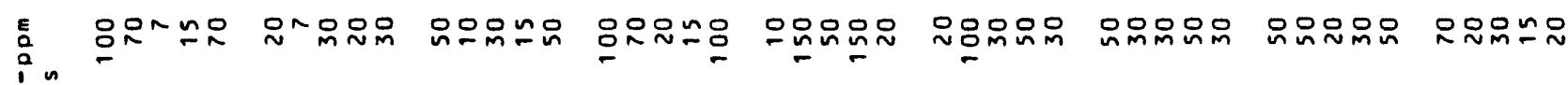

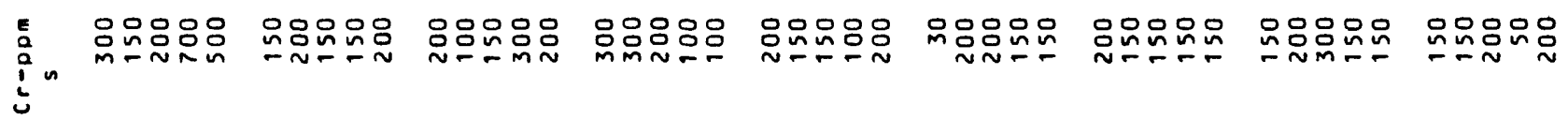

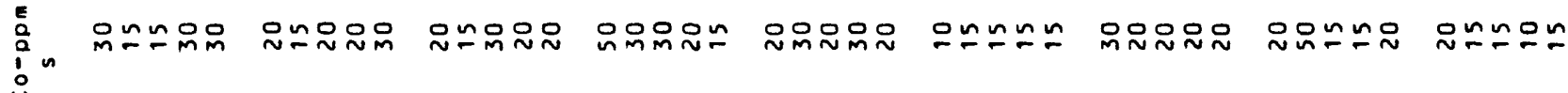
E
:
in E $i_{\infty}^{\infty}$

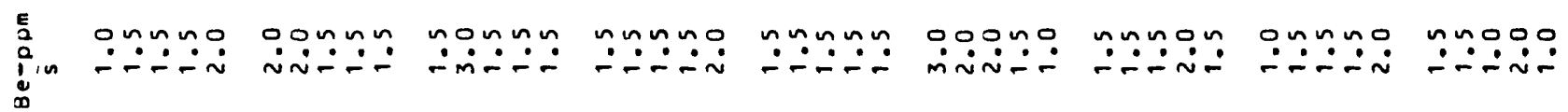

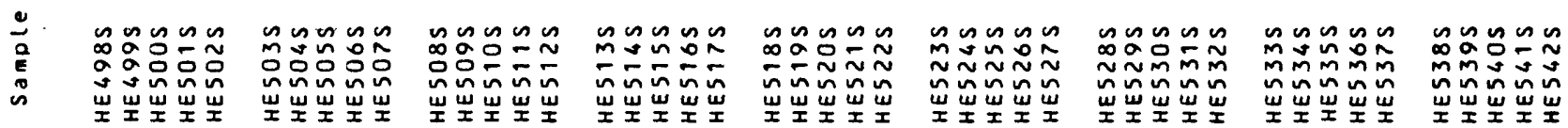




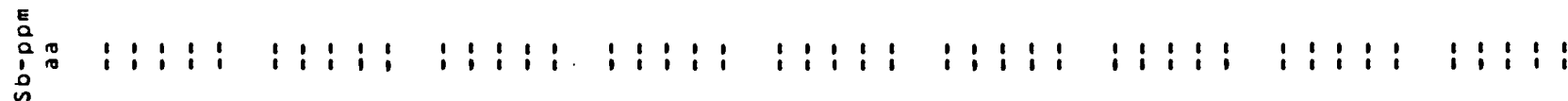

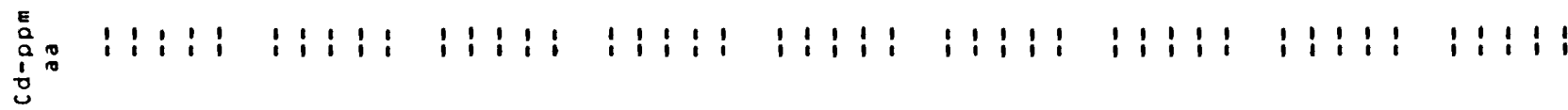

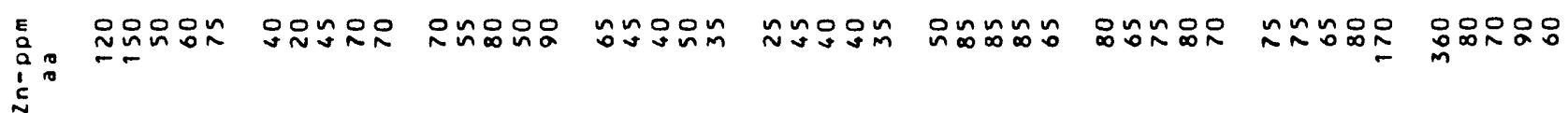

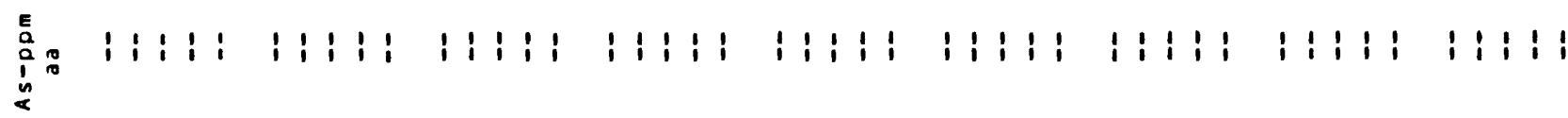
:

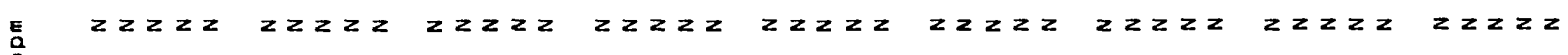
$i^{i} n$

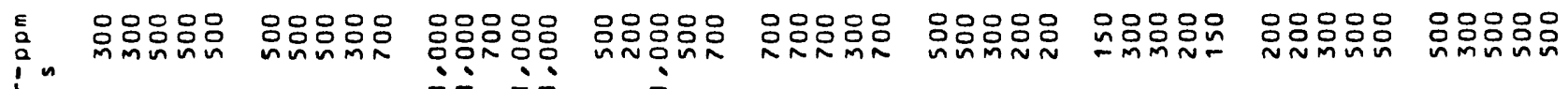
!"

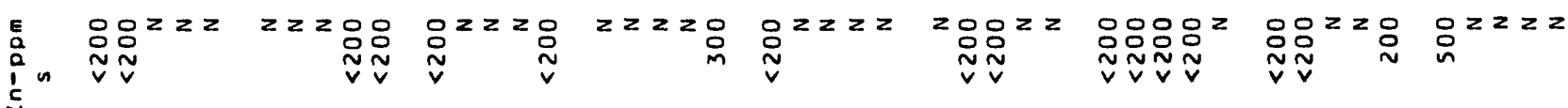

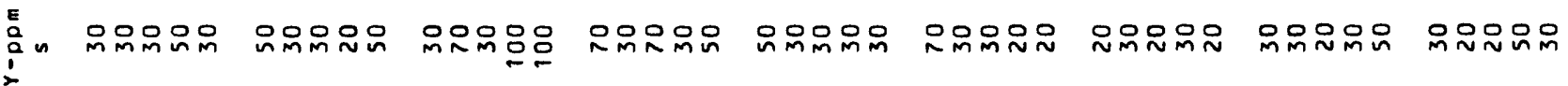

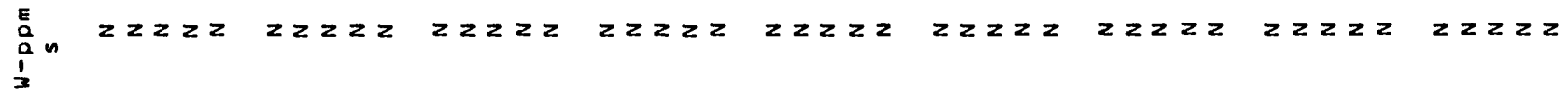

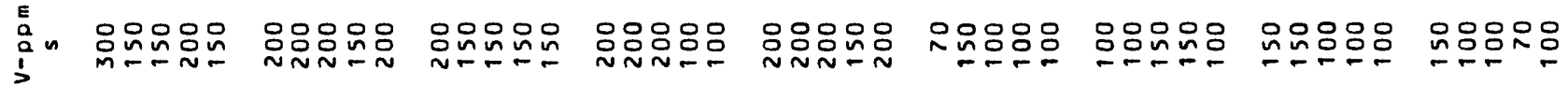

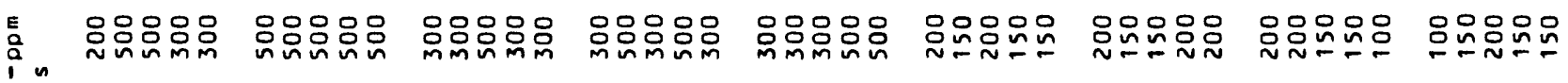
in

E

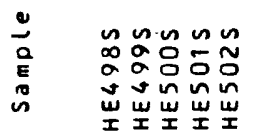

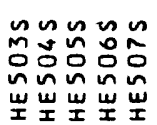

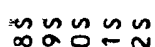
mon

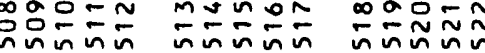

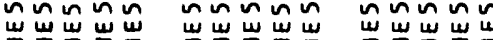




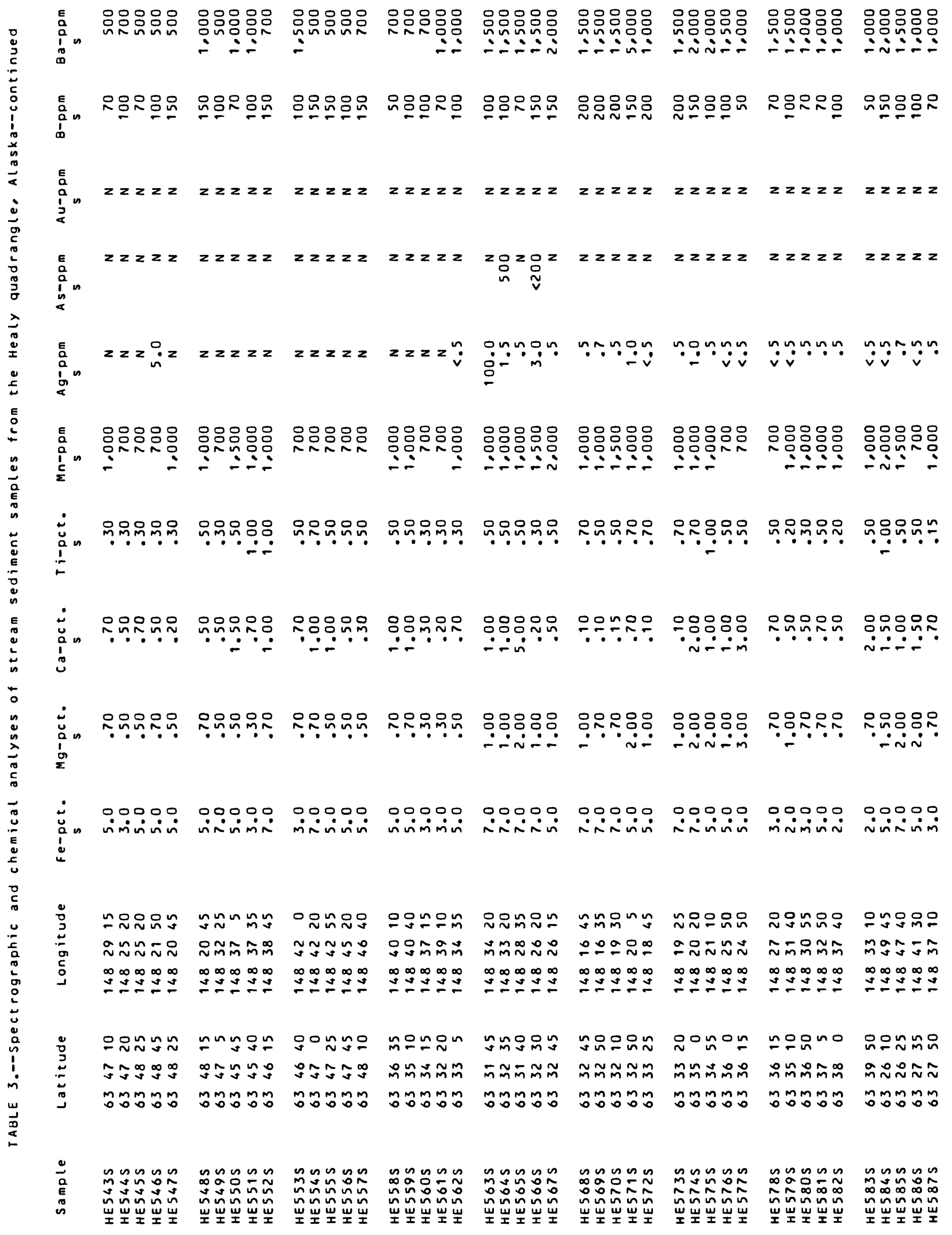




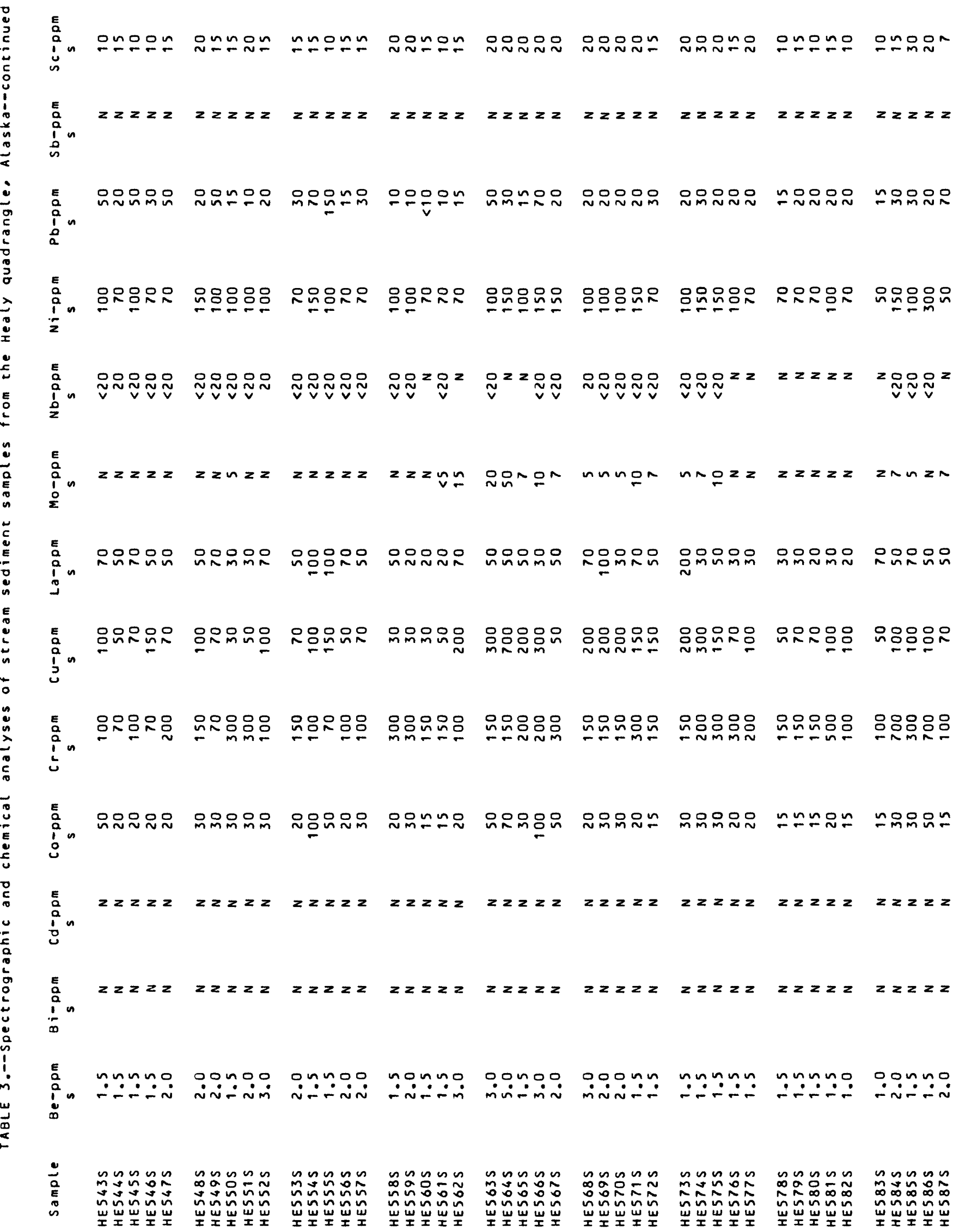




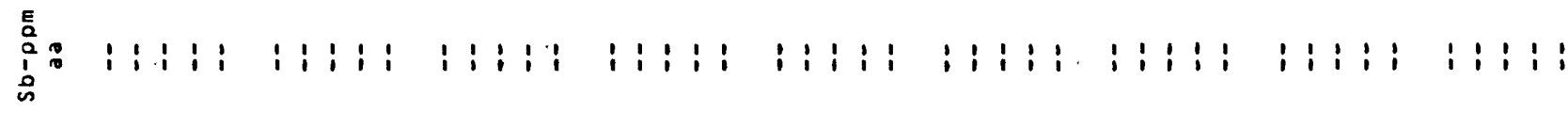

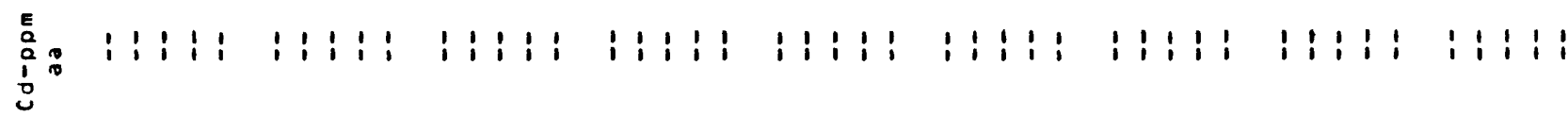

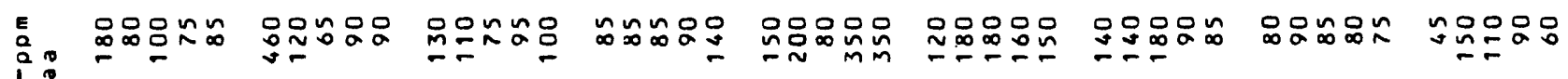
$\stackrel{n}{1}$

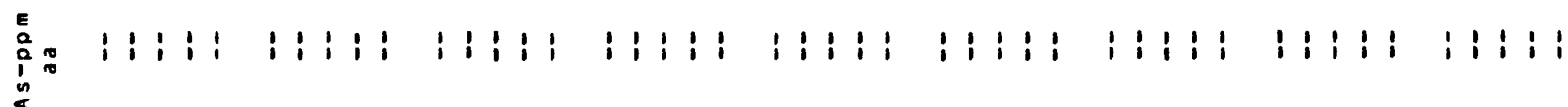
:

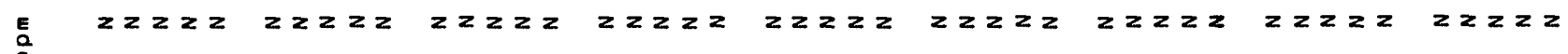
$i^{2}$

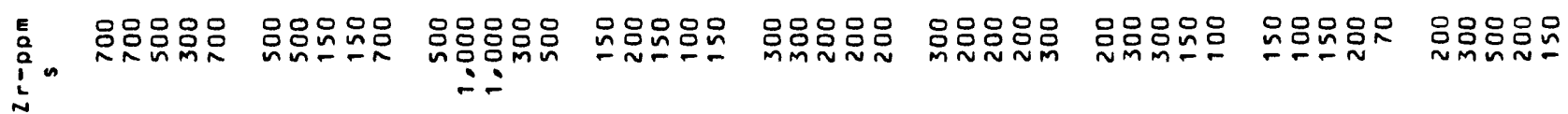

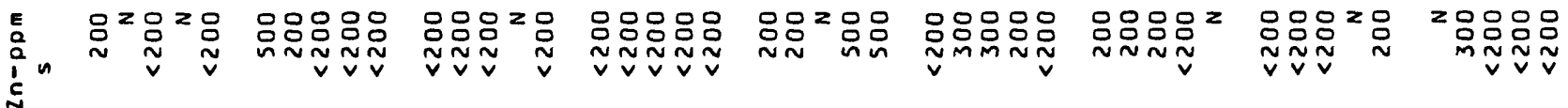

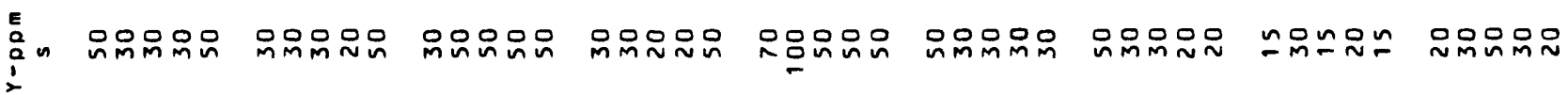

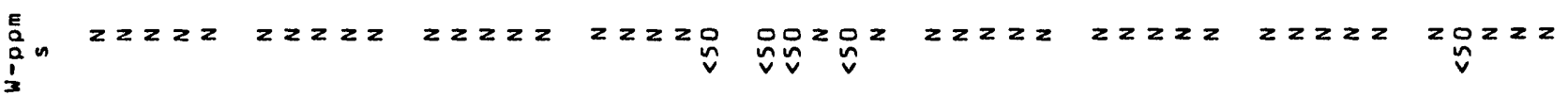

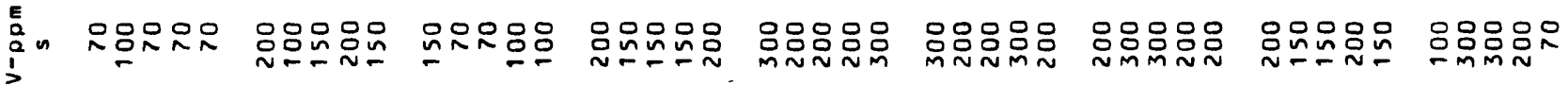

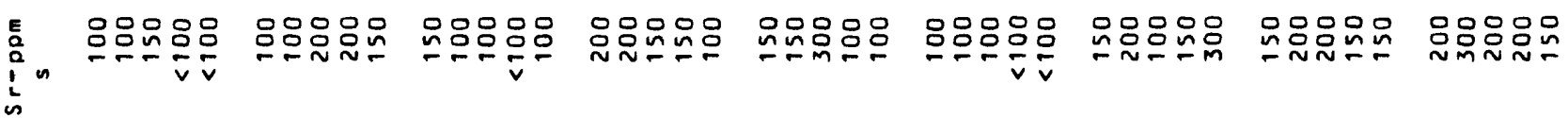

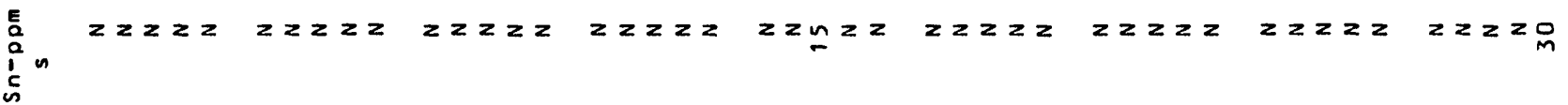

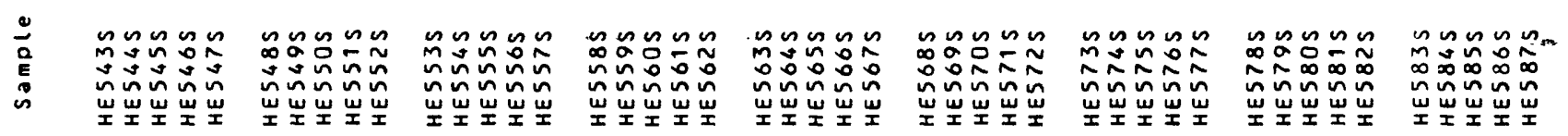


옹요음

웃움웃웃

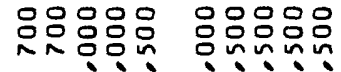

in:-

mำ

응으응

的茫的

웅움응

是望品

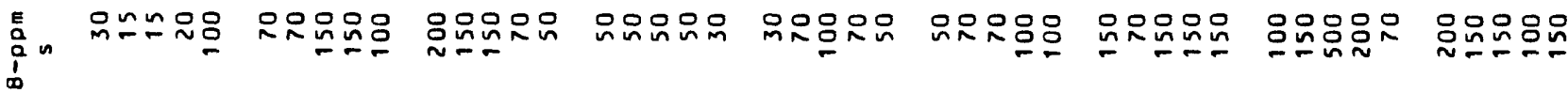

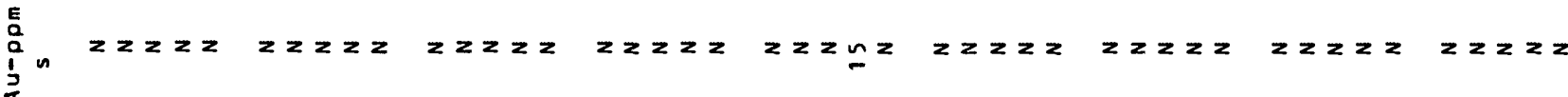

E

$z 2 z 2 z$

$z 2 z 2 z$

$z \underset{\sim}{\stackrel{O}{\sim} \underset{v}{O}}$

$z z z z z$ $<$

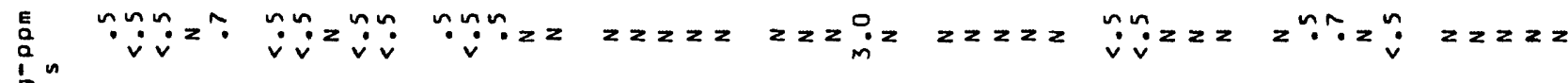
$<$

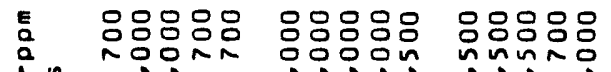 \\ in}

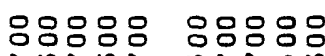

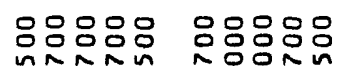

응옹용옹음

응응응웅음

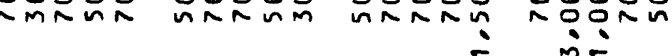

$\because \because ! n$

ㄴํㅇํํ

$\stackrel{\vdots}{\vdots}$

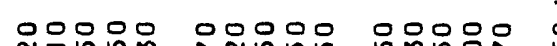

'ं0000 00000

운음운요

웅ㅇㅇ웅

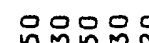

은오웅유

‥?

เท!

๑.・

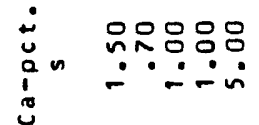

응응응음

웅ㅇㅇㅇㅇㅇ

옹ㅇㅁㅇㅇㅇ음

웅으웅ㅇ

읐드는용

늠유오

은옹ㅇㅇㅇㅇㅇ

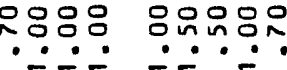

\section{-}

은믓음

응옹응음음

00000

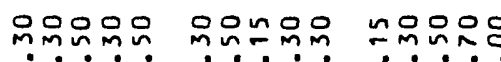

응융응요

운응응은

$\because \because \therefore-\therefore-i \dot{-}$

유응ㅇㅇㅇㅇㅇㅇ

$$
\begin{aligned}
& 0 \\
& a \\
& \vdots \\
& 0 \\
& \Sigma
\end{aligned}
$$
ن́ñ் í-

\section{ú}

00000

00000

ono 0 ?

o000n

no:?

00000

00000

00000 (1)

의ำํำ

ํํㅁํำ

$\approx n n \infty \infty$

$m \infty n \infty 0$

ㅇำกษ $m$ m

$\infty \sim ⿻ 上 \infty$

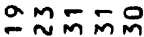

å용

$a--0 n$

กิบนที

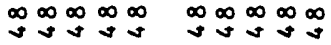

$\infty \infty \infty 0$

$\log 00$

$\infty \infty \infty \infty \infty$

0
$\infty$
$\infty$
$\infty$

은ํำ

ษ

minon

응요 $\sim$

on $\operatorname{nn}_{n}^{\infty}$ måฐ 눈용

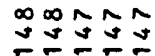

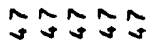

กヘกヘ 苾出 00

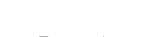

nonoo

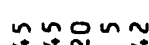

$\sim \sim a \sim \infty$

aㅁํํ $\stackrel{\infty}{\sim}$

น

$\neg \approx m \backsim s$

$\approx$

$\simeq \sim \sim \simeq \sim$

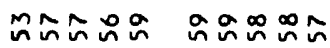

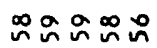

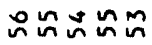

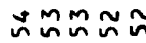

$\tilde{\sim} \approx \Sigma 0 \Sigma \bar{\sim} \approx \tilde{N}$

옴ํำn

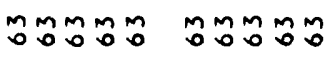

mŏ

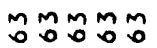

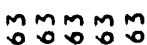

กับป

o용의

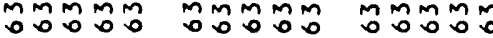

00000

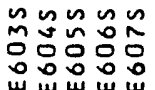

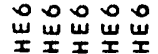

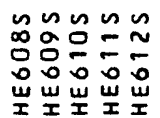

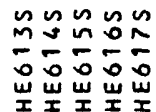

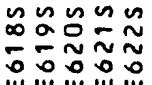

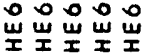

$n \sin n$ กัก๊̃ 现岕岕㟧 unnun 空品的

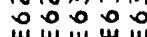
出出出 


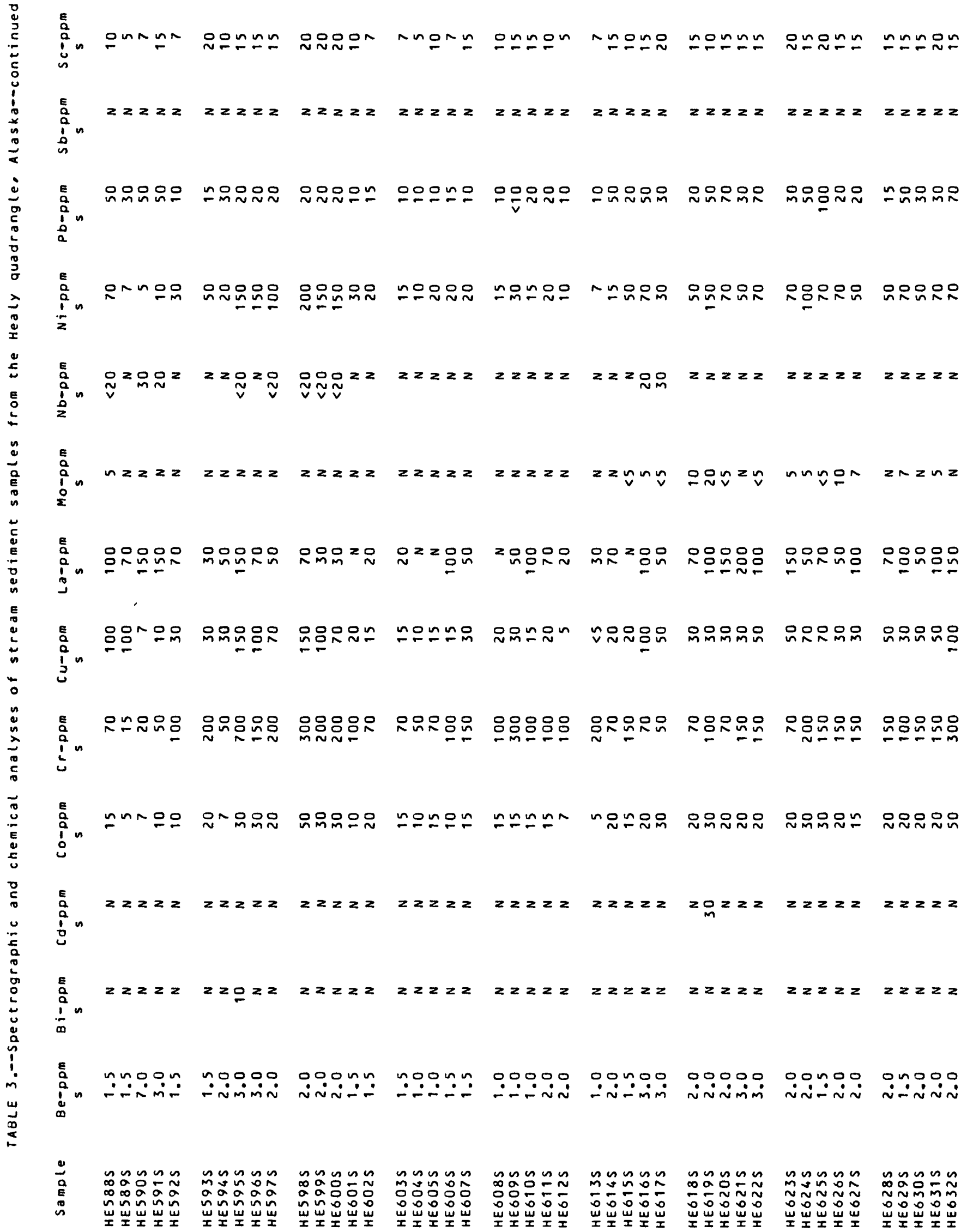




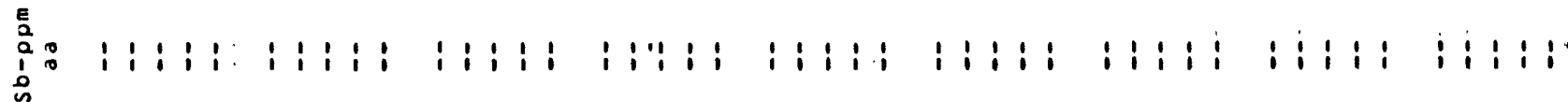

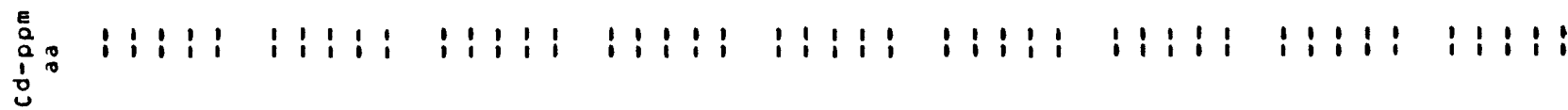

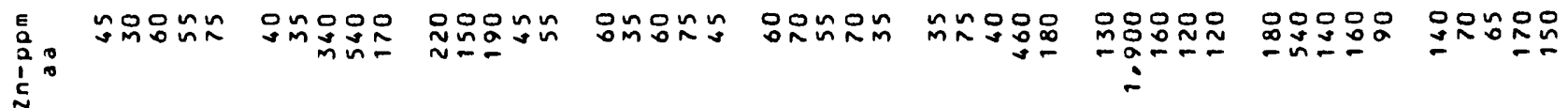

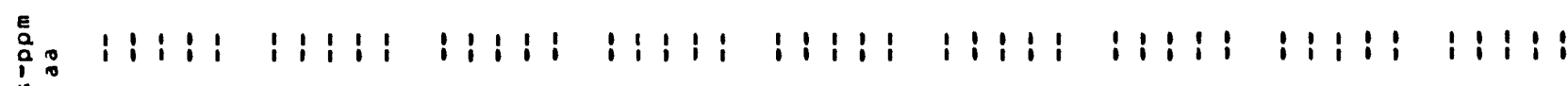
$<$

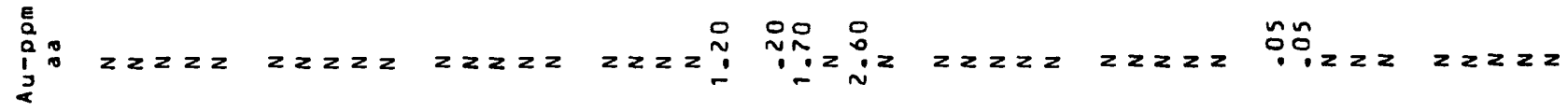

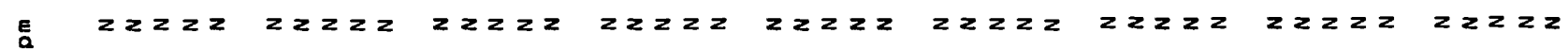
$\sum_{i}^{0}$

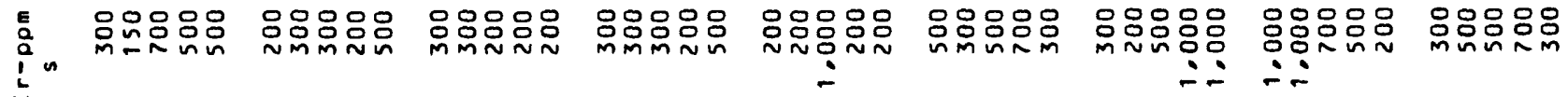

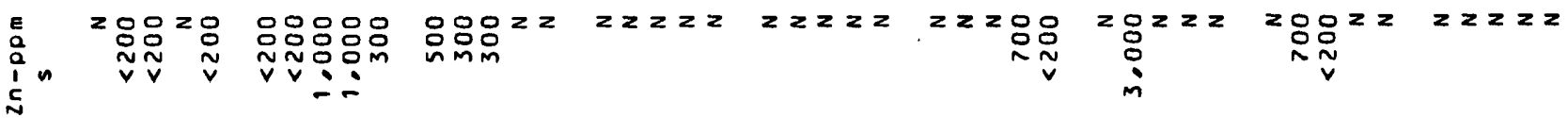

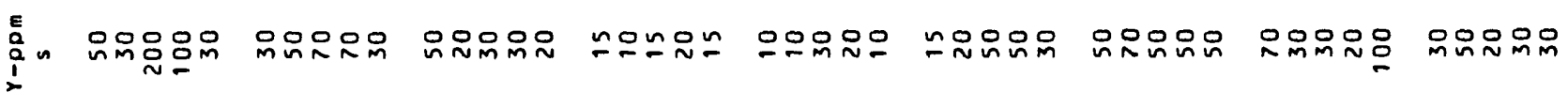

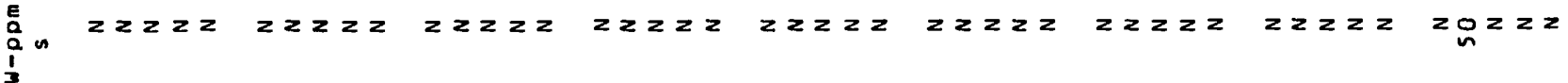

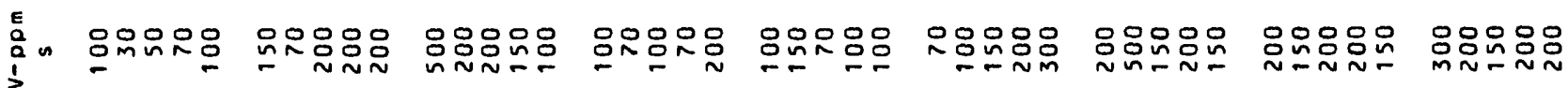

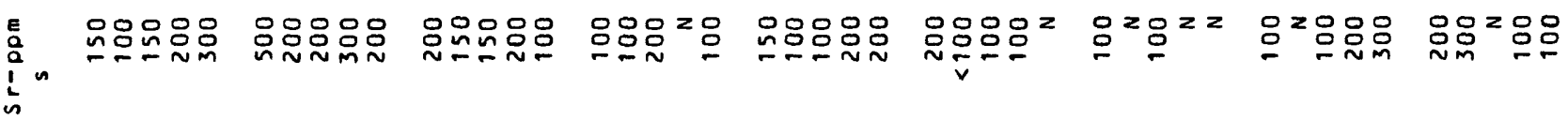
E

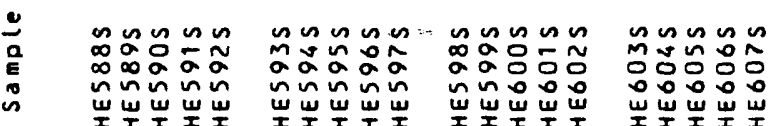

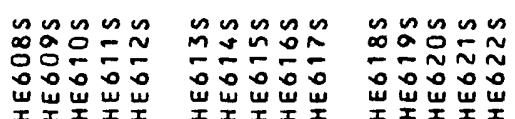
$\tilde{m} \sim \sim n$ N Nmmm

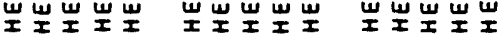




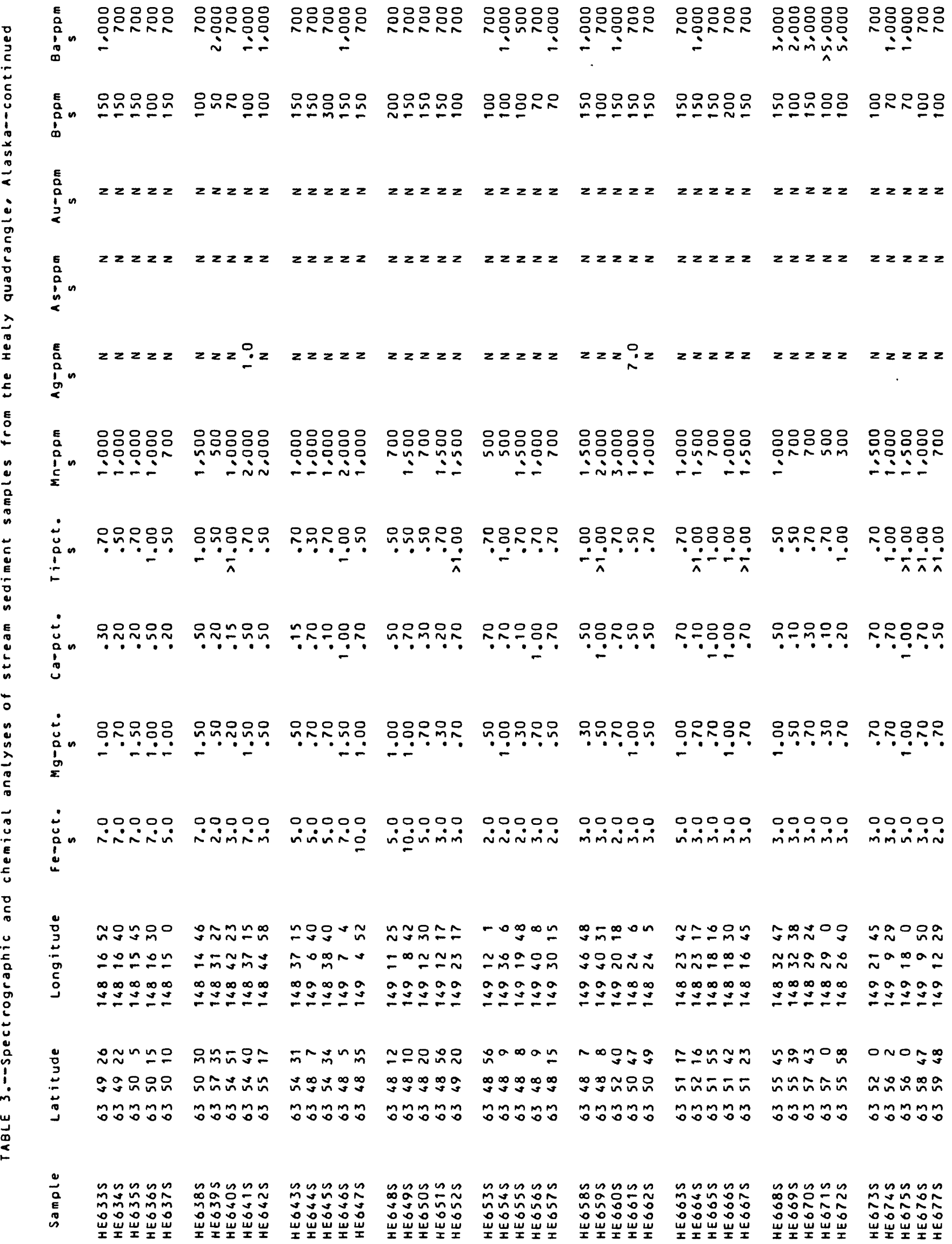




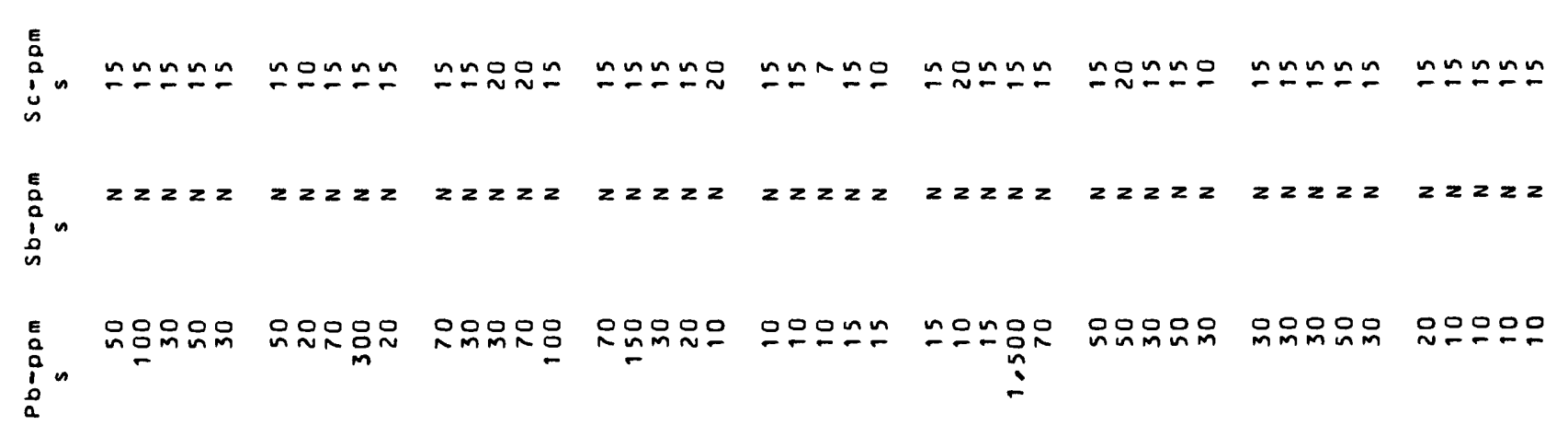

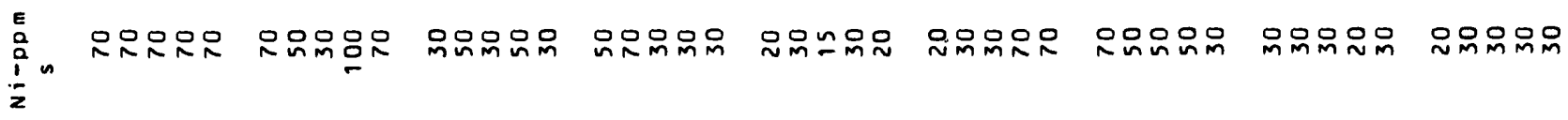

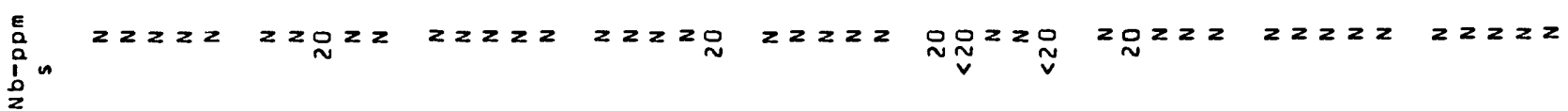

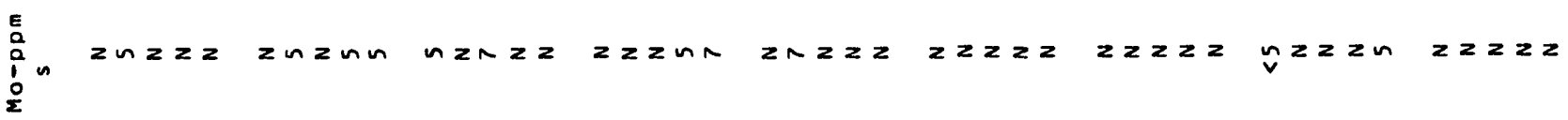

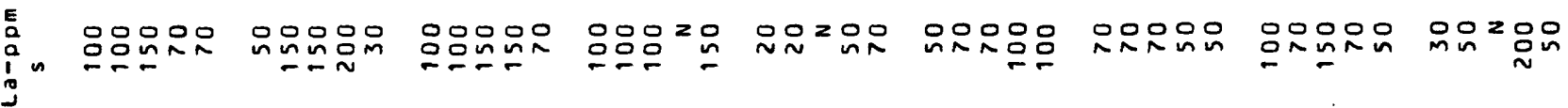

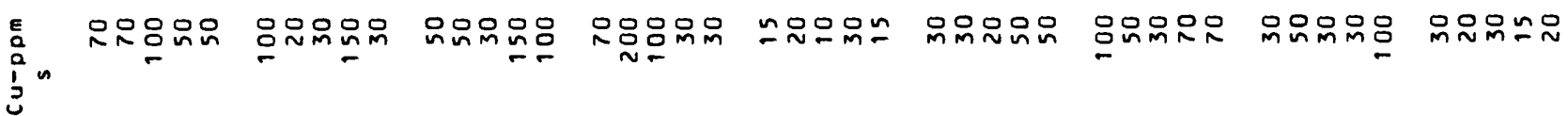

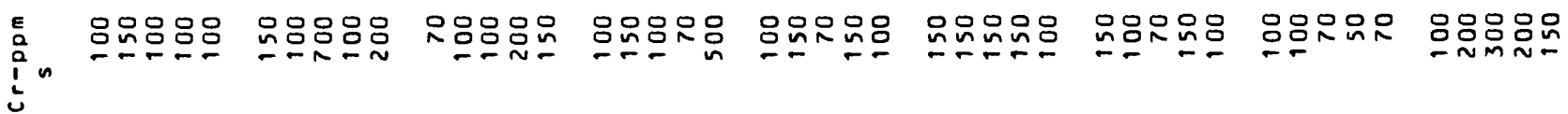

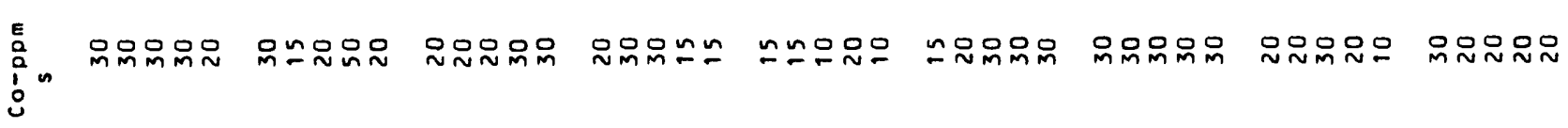
否

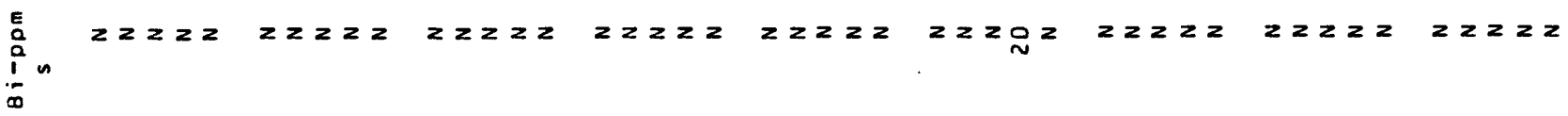
!̆

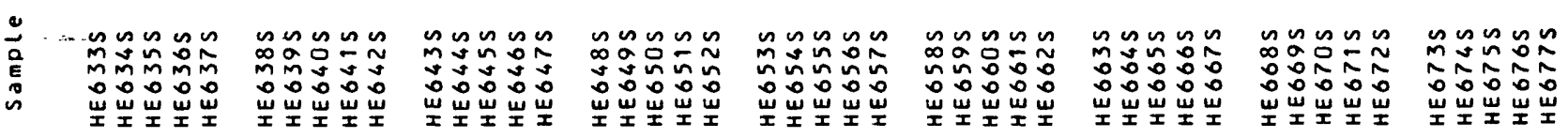




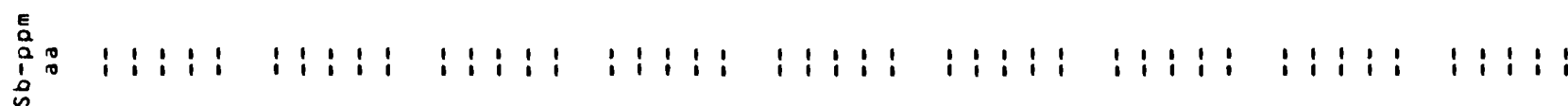

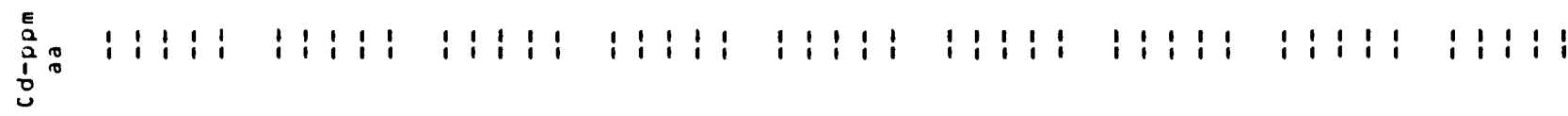

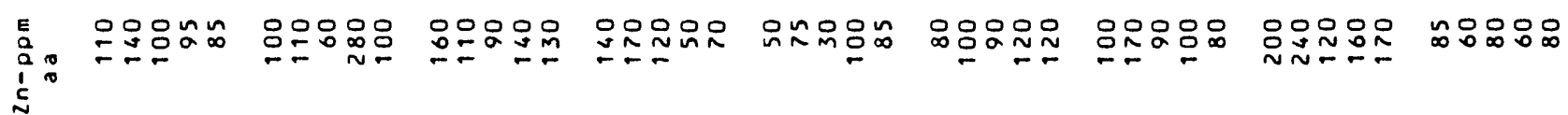

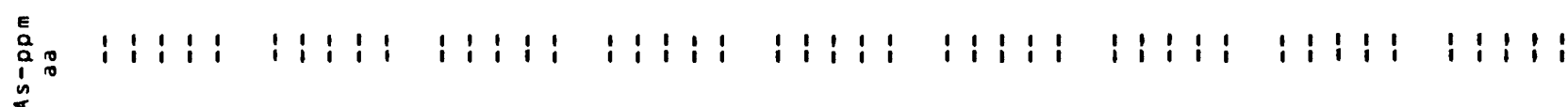

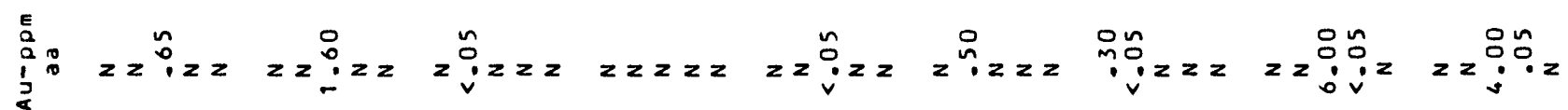

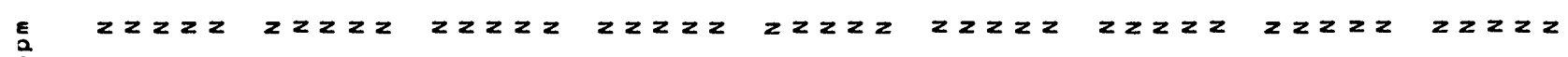
$\stackrel{2}{2}_{\substack{2 \\ 1^{2}}}$

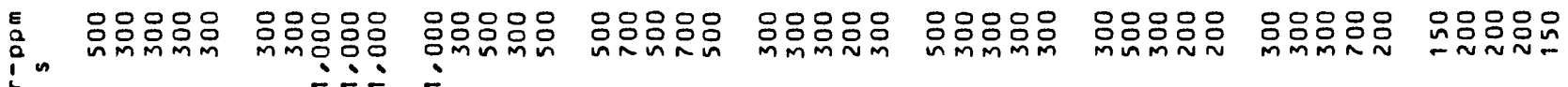
$\therefore \quad \div \div$

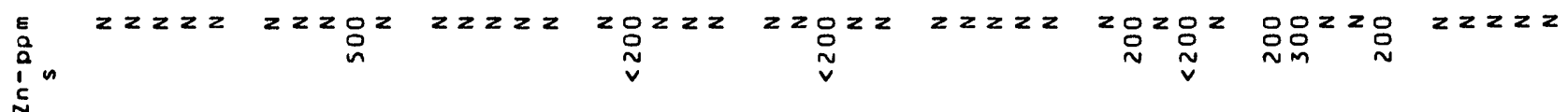

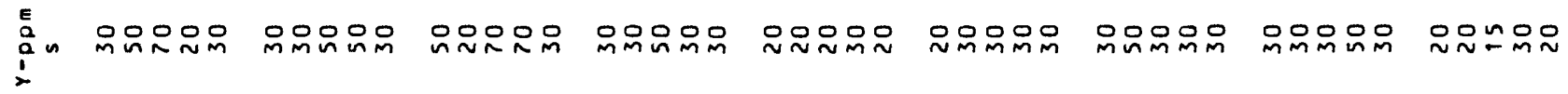

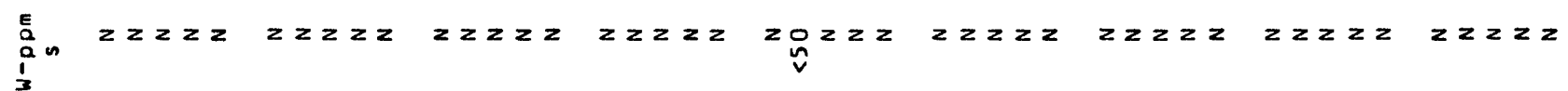

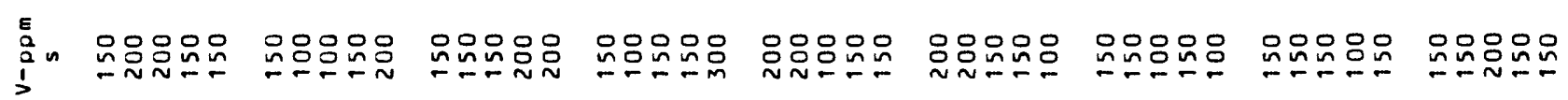

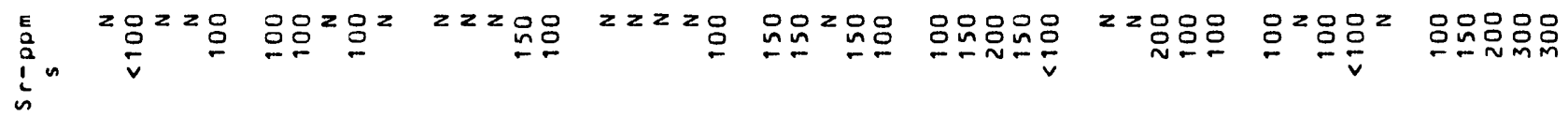

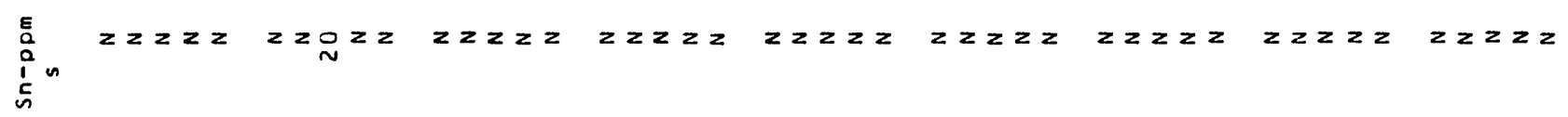

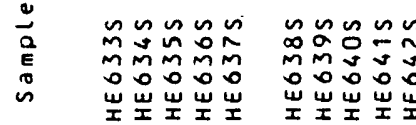

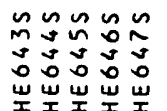

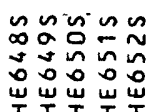

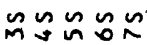




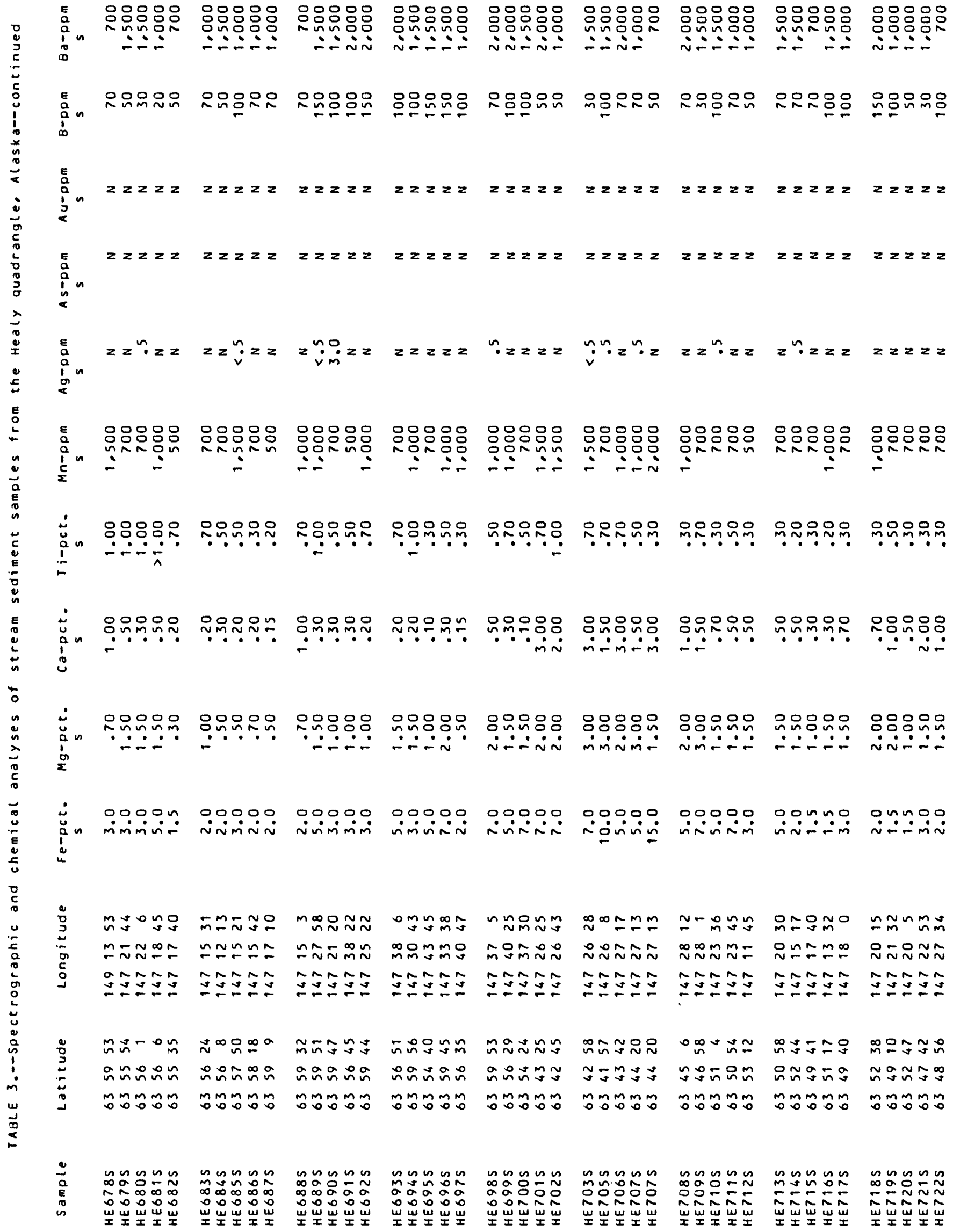




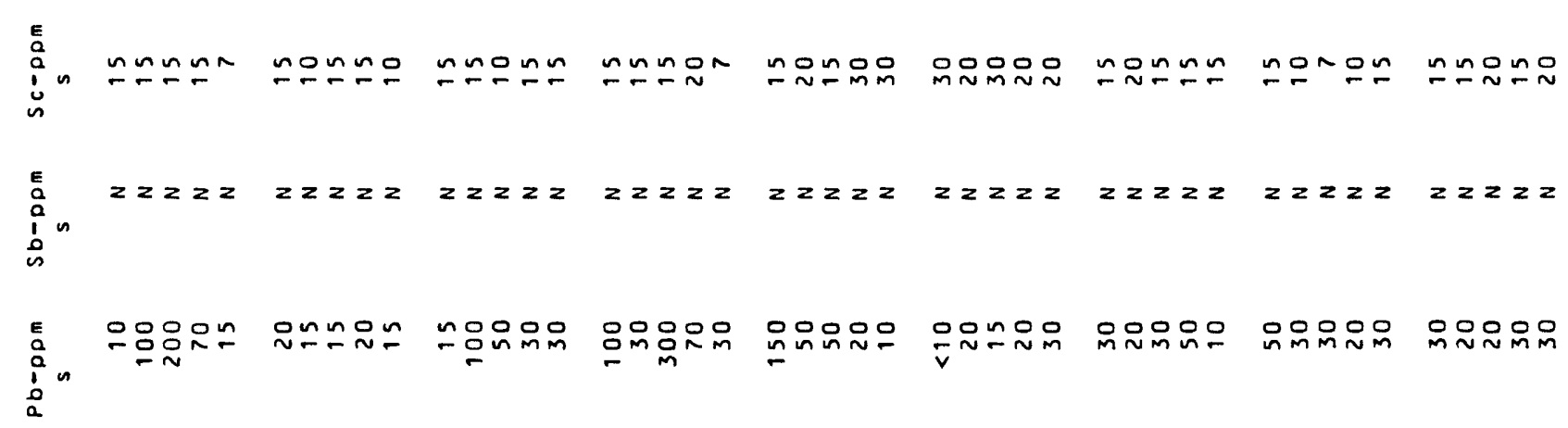

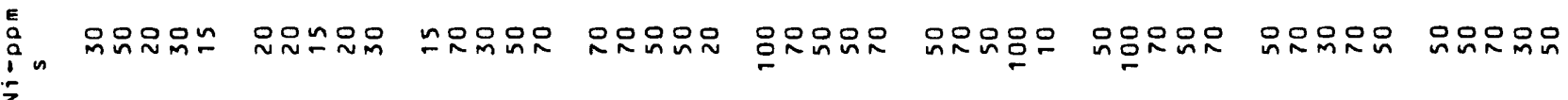

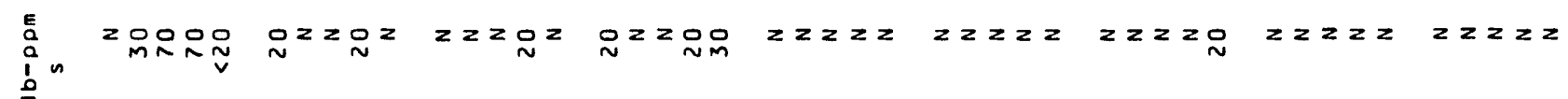

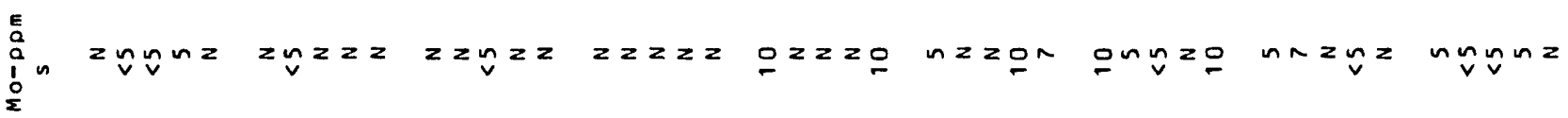

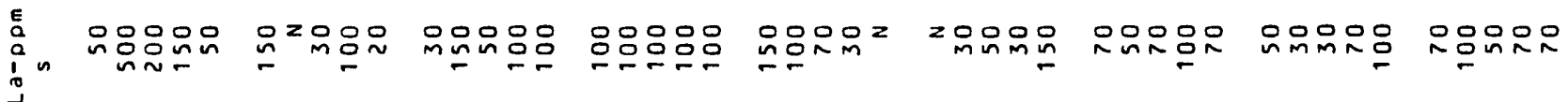

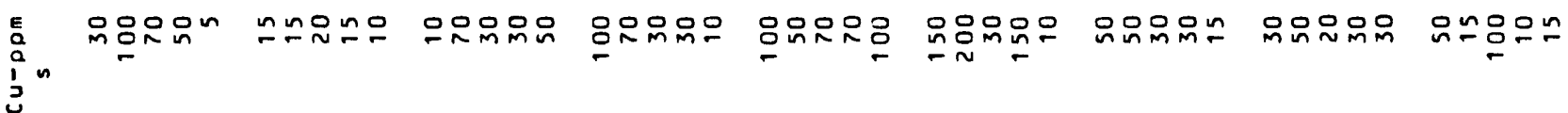

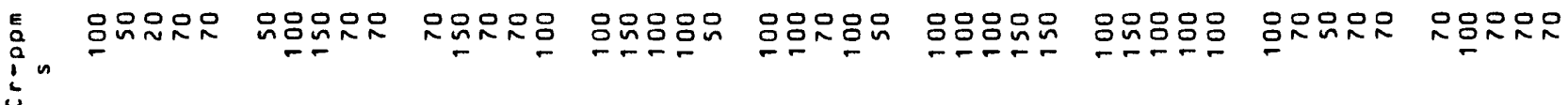

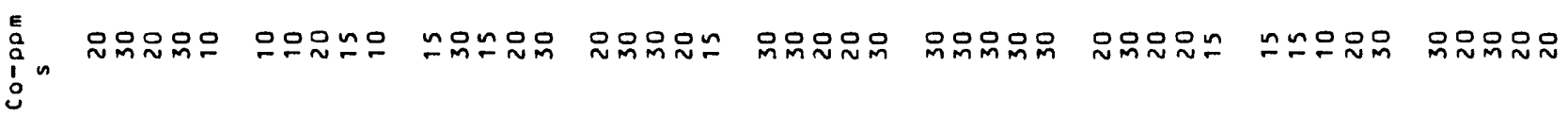

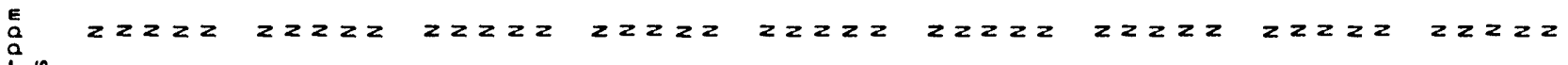
$\dot{b}^{\prime}$

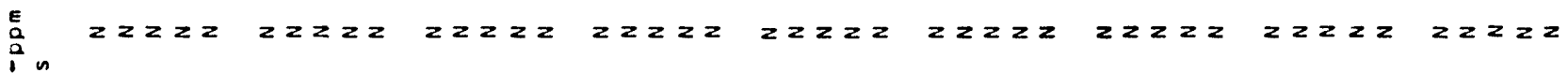
$\therefore$

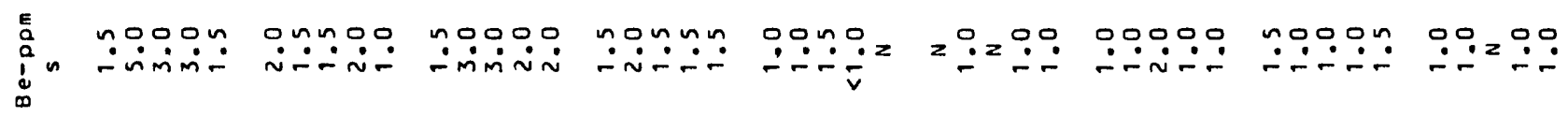

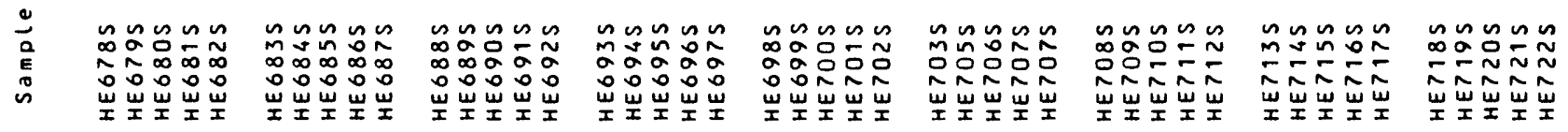


镸最

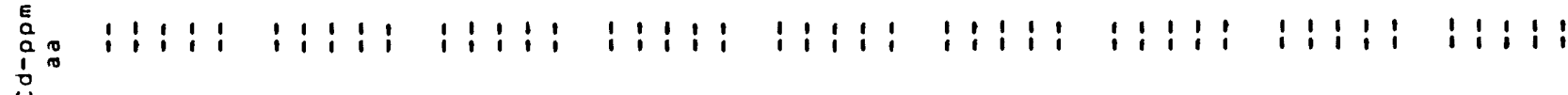

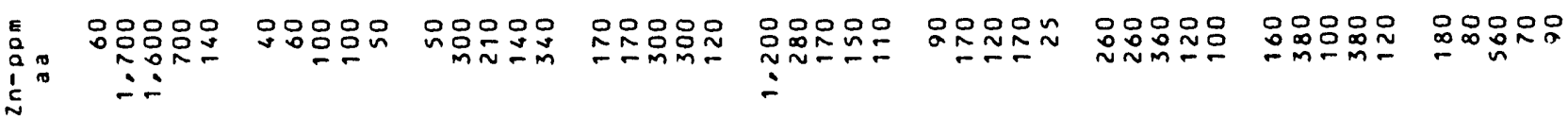

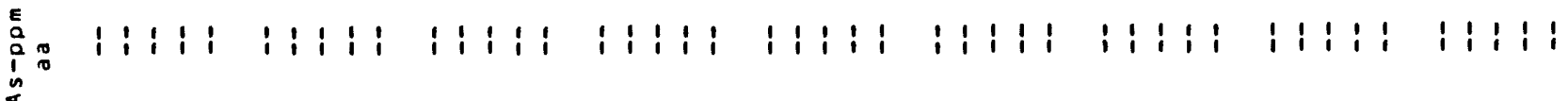

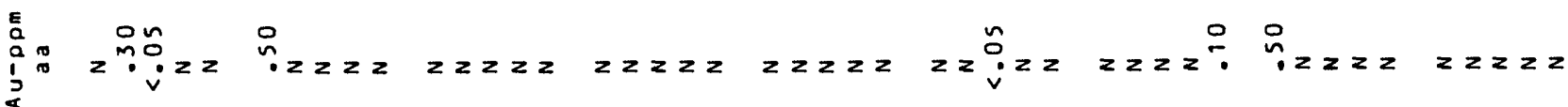

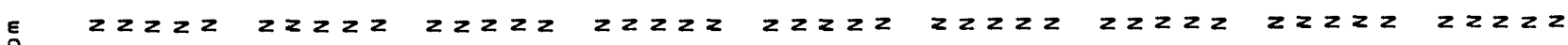
$i^{2}$ i

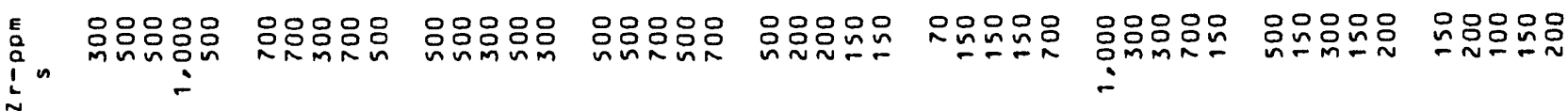

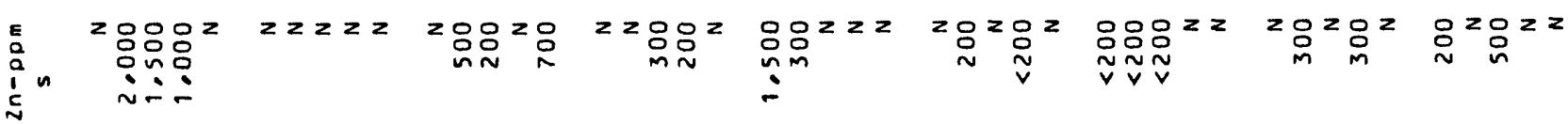

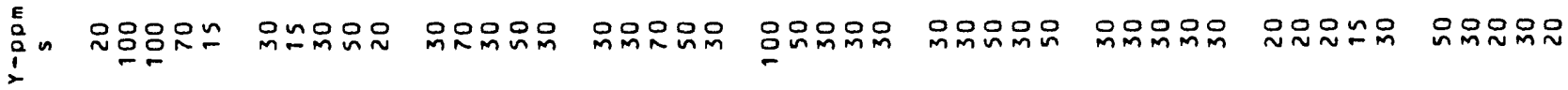

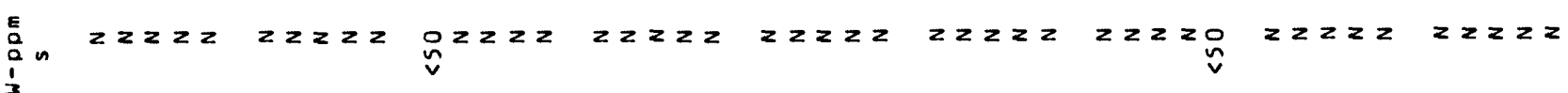

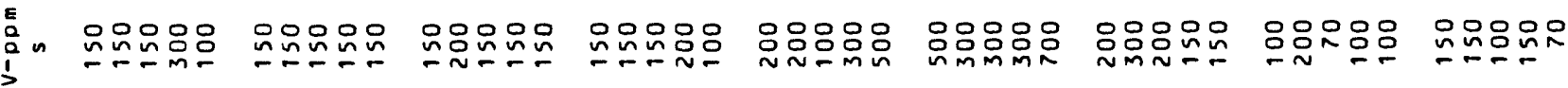

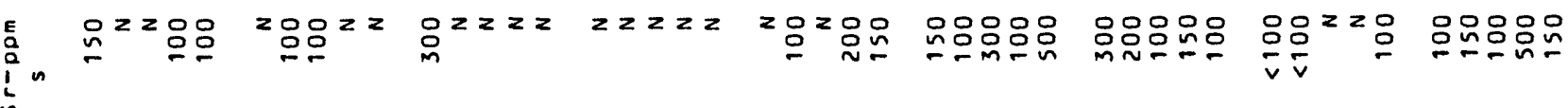

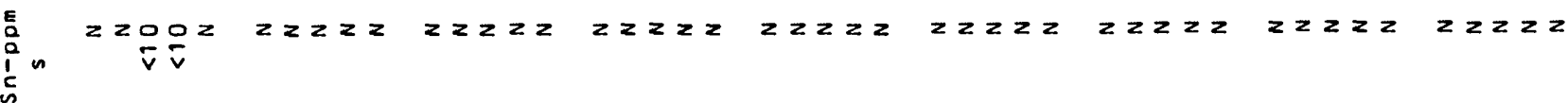
is 


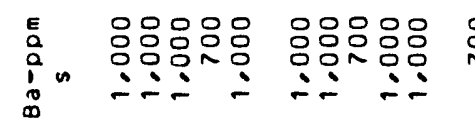

E

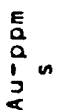

En

$z z z z$

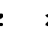

$z z z$

2

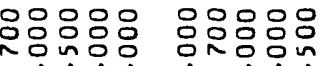

$\therefore \therefore:$

눈?

응융응응응

$\therefore \div$ i:

순

웃윰욤요

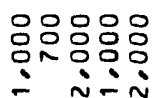

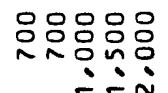

응응윰ㅇㅇㅁㅇㅛ

ini

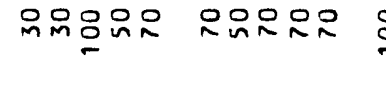

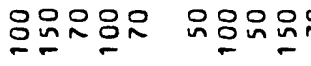

융ㅇㅇ으뭉

웃응ㅇㅁㅇㅛ

옹응요

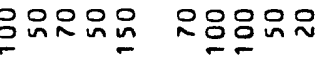

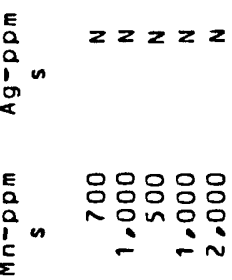

$z \stackrel{n}{n}=2$

$z z z z$

$\stackrel{m}{m} \cdot \tilde{v}=2$

$z \stackrel{n}{*} z=$

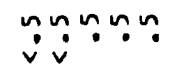

$\because \because \because \sim^{n}=$

$z z z z \stackrel{\circ}{\sim}$

$\dddot{n} \because \because \tilde{v}^{n}=$

ín

이잉

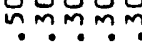

음응음

ำ 눈

은은은은은

음웃움운

옹응옹으

ํํํํำ

음은은운

음음음옹

옸옴ㅇㅁㅇㅁㅁ

웅ㅇㅇㅇㅇ

ำ-

$\sim \sim$

운윳웃음

옹ㅇㅇㅇ웅

$\because \because \frac{1}{4}$

웅웅응

음오운음

음윤우운으

웄웁음용

$\therefore$

움웅우오.

으눈옹음 추

范

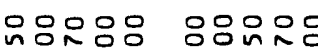

$\therefore \dot{\sim} \because$

움ํㅜㄴ음

응응응 옹응ㅇㅇ음

옹웅으

00000

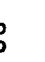

음윰웅요응

$\dot{m} \dot{\sim} \dot{m}$

$\dot{\square}$

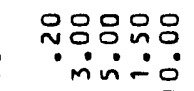

응요

vinimina

- min

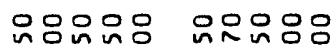

ทำกำ

$\because \because \because \dot{\sim}$

옹우운음

음으움응

운유웅음음

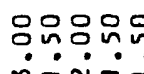

잉

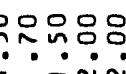

옹ㅇㅁㅇㅇㅁㅇ

으은용ㅇㅇ

$n-n-n$

$\because-m$ m

00000

00000

00000

00000

00000

00000

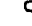

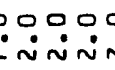

in no

$\because 0000$

inivion

u.

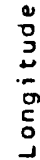

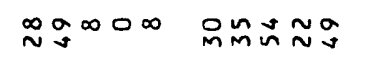

어ำ

nO임욤

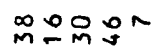

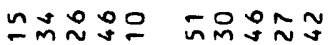

융

usono

$m \underset{N}{m}+$

$\tilde{\sim}-\stackrel{0}{\sim}$

oง 㝵告

ํำ品的的

ษัษษ์

尌往掏

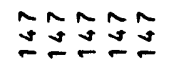

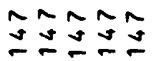

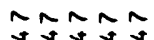

juysizy

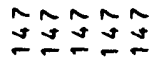

$i^{\infty} 00 \hat{n}$

ñ ñg

궁의의

mmovg

$\mathfrak{y}\{\mathfrak{a}$

ิิษกิ์

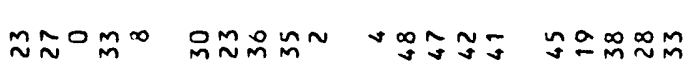

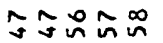

$\stackrel{\infty}{\sim} \underset{\sim}{\sim} \mathfrak{m}=$

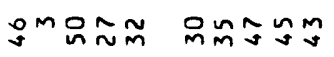

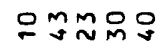

a

minn

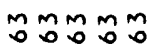

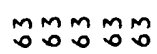

mmmmm mmmmm

mmmmm

$m m m m$

mmmm

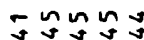

$\begin{array}{lllll}m & m & m & m & m \\ 0 & 0 & 0 & 0 & 0\end{array}$

ก

ind

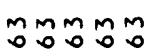

แnก⿻上 $\tilde{N} \tilde{N} \tilde{N} \tilde{N}$

琹岕岕琹

กะกน

事品

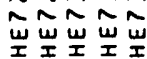

nusun

MMnMm Máñ

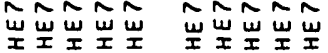

innosing

MNㄴำ

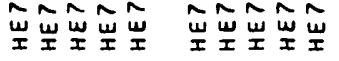

coscos

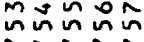

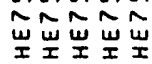

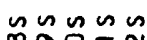

in

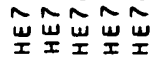

nnuna

mป๊ำ

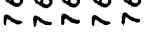

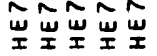




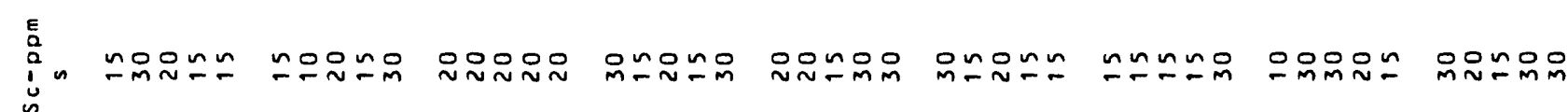

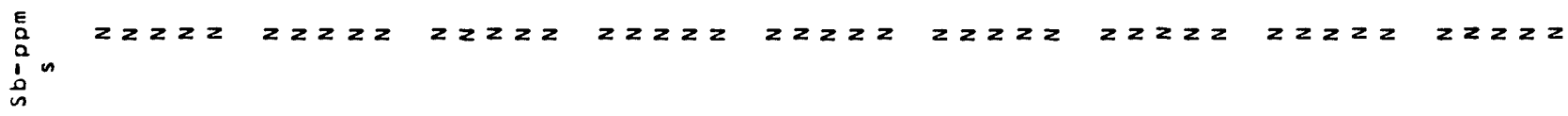

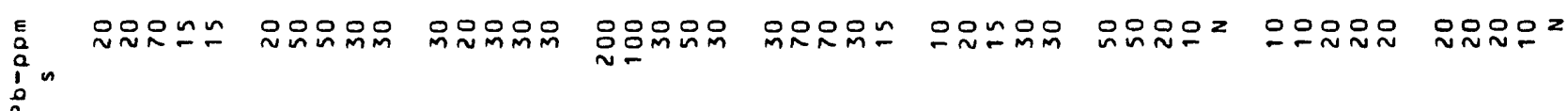

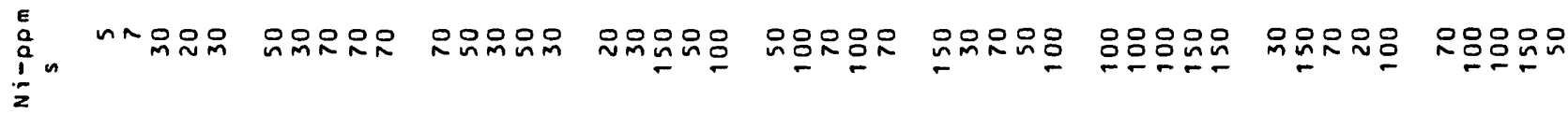

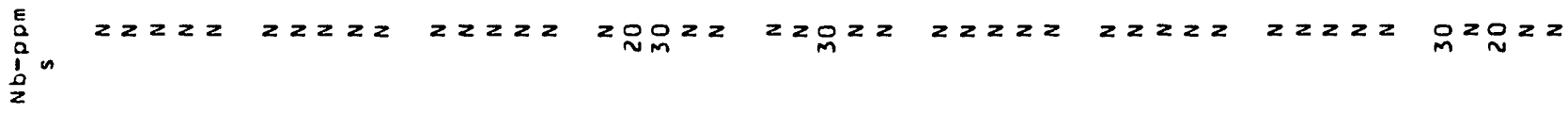

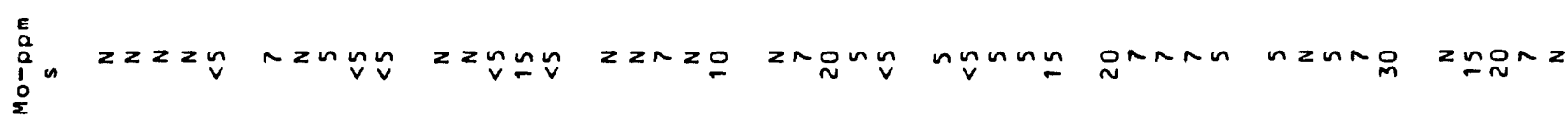

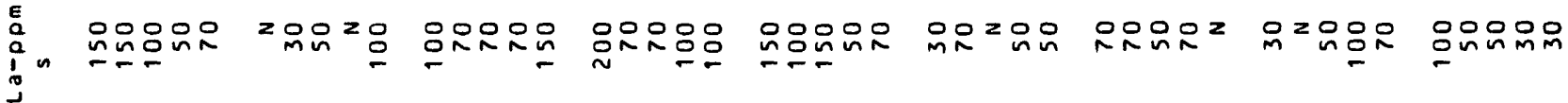

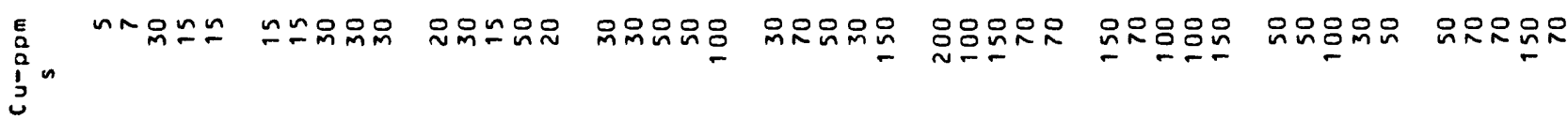

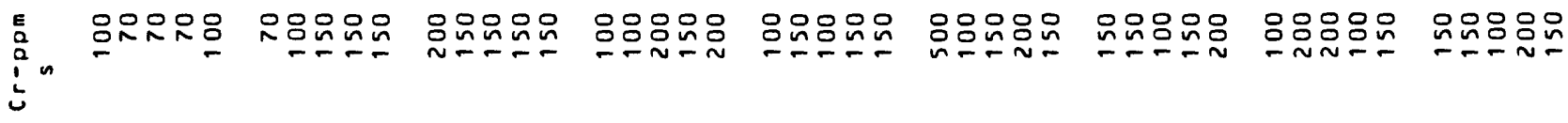

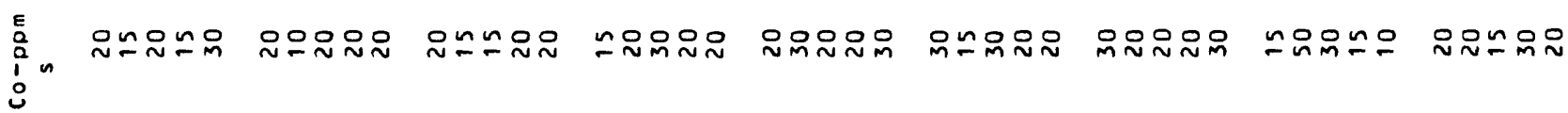

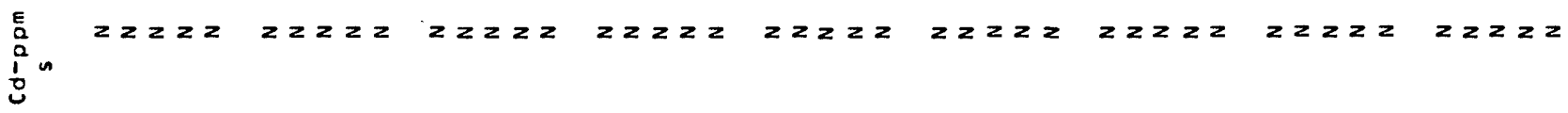

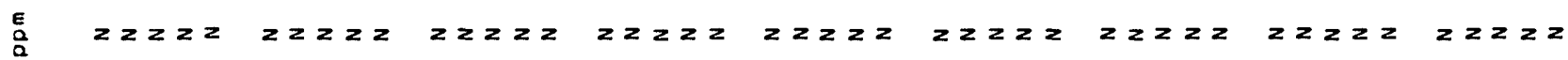
$i^{a}$

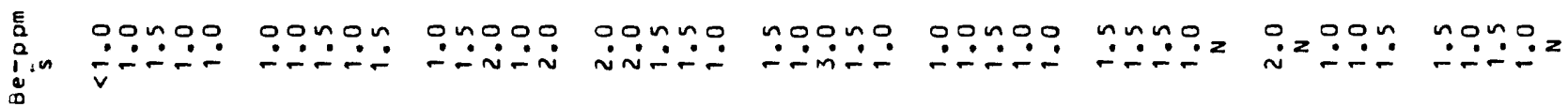

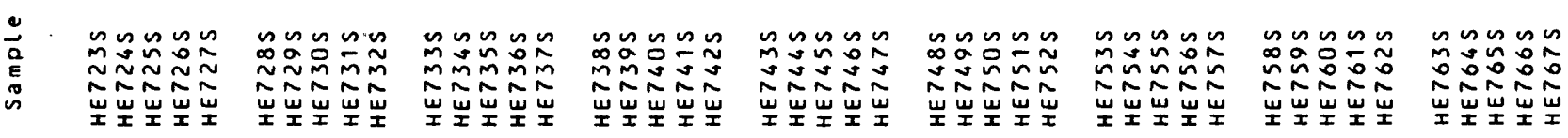




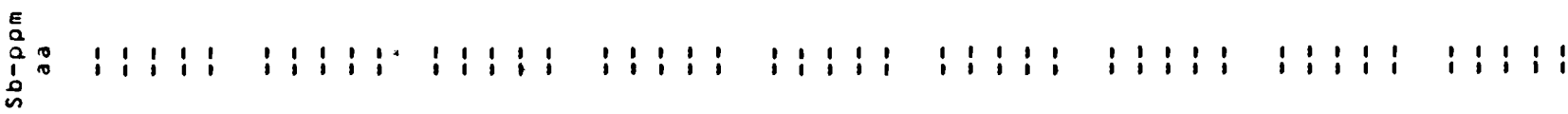
镸

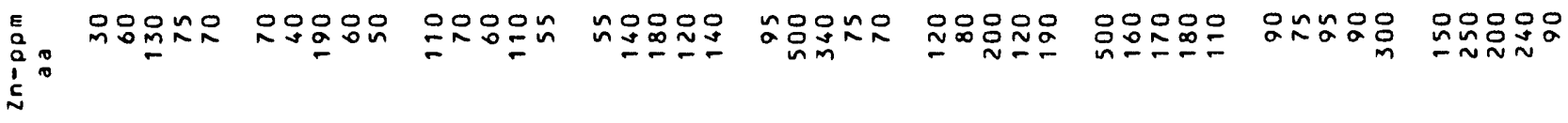

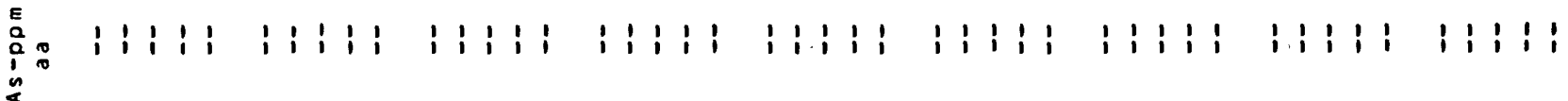

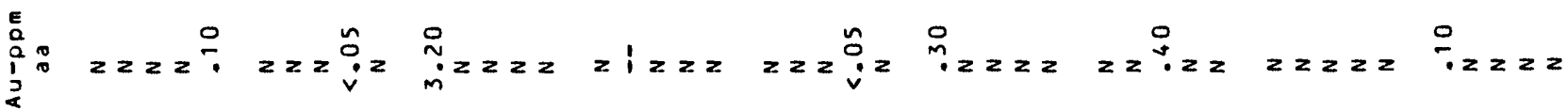

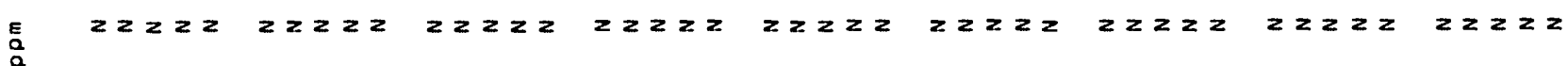
$i^{1}$

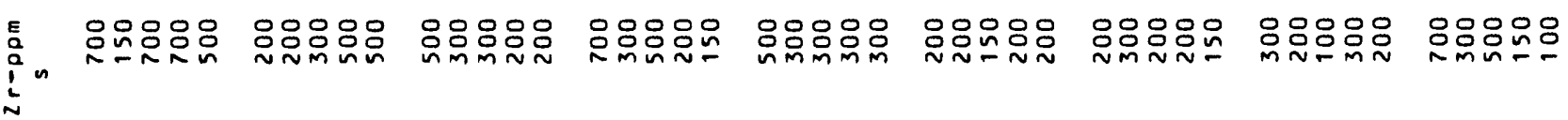

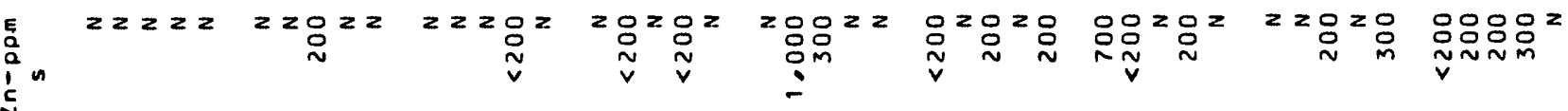

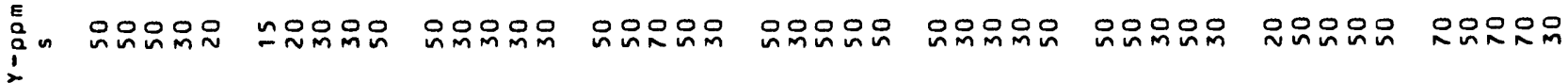

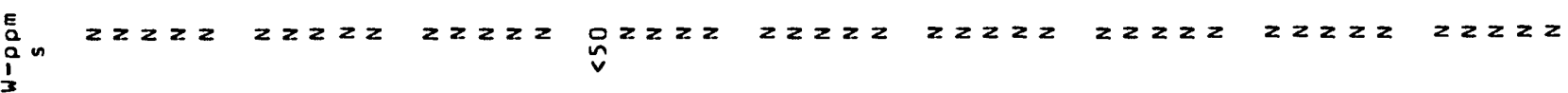

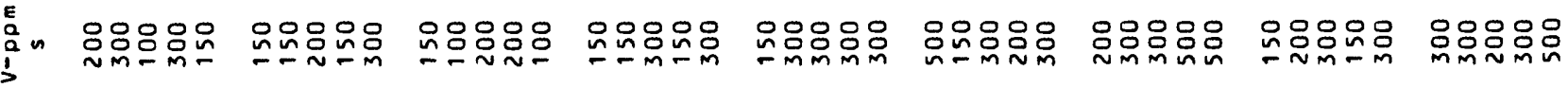
言 笵

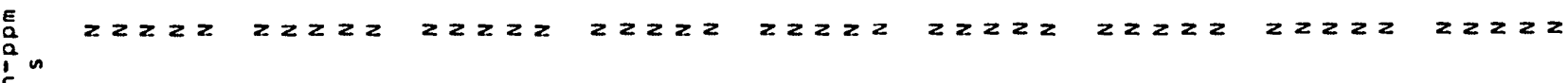
它”

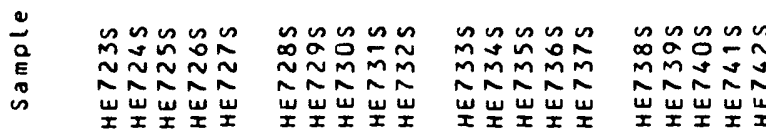

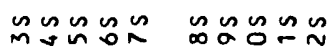

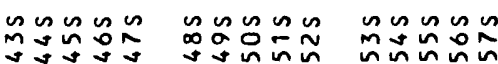

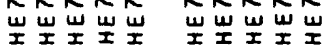

กะก $⿻ 上$ nn กิำนัำก

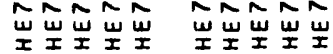




$$
\begin{aligned}
& \text { 7: } \\
& \text { 1. }
\end{aligned}
$$

옹ㅇㅁㅇㅜ

웅응음

응웅ㅇㅇㅇ

ทัュำ

능음요 운

$\stackrel{:}{\breve{a}}$

응으 응응

00000

00000

o0000

00000

용ㅇㅁ음

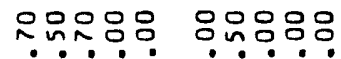

1
0

vininim vimgiñ

$\because$ in m

ำกำ

… …뭉

imin-

붓 우숨움

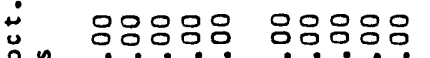

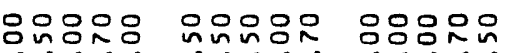

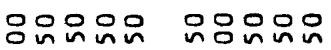

ำกำ.

กับทำ

옹응ㅇㅇ

애옹옹응

نंivinim mininin

n- n

$\because \because$

$\therefore-$

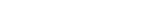

范

00000

00000

00000

00000

00000

00000

00000

00000

00000

ningin

ononin rinisio

ininis

vimin

inininis

vinisin

نिininim

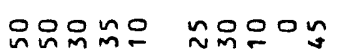

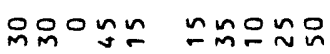

oginnim

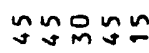

m

ong gng 品感的出品 ทำกำกั

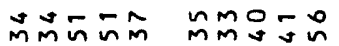

ONMOO

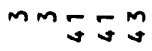
ga活识的

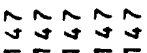

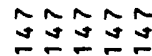

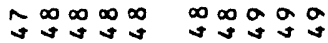

gagas

gagag

gagag

응ㅇㅁ용ㅁㅇ

noㅇำ 品专的昌

守的旅

a a a a a a a 000

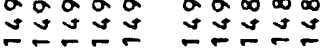

을웄ํㅜㄴ

$\approx 0 \sim 00$

웡요요

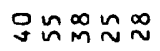

ทั่ำำ

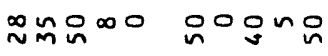

mㅇN누음

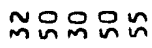
งษง

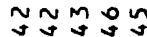

원웡워

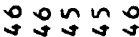

워용

テテ祭品

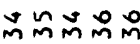

ติำกำ

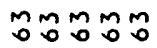

м⿻ำ

ติำณำ

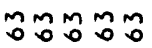

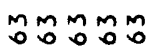

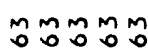

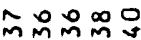

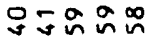

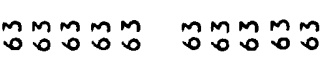

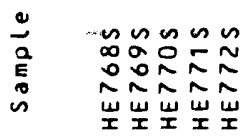

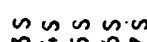

$n \backsim \backsim n n-n \backsim \backsim n n$

ลิกล์ล กิ์

岀岕岕岕岕

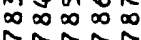

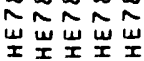

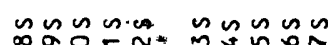

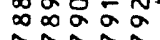

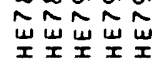

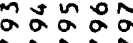

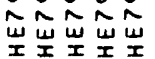

ผุณณณ 2음융

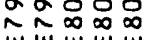

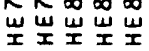

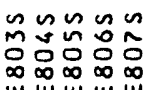

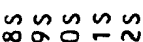

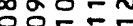

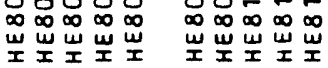




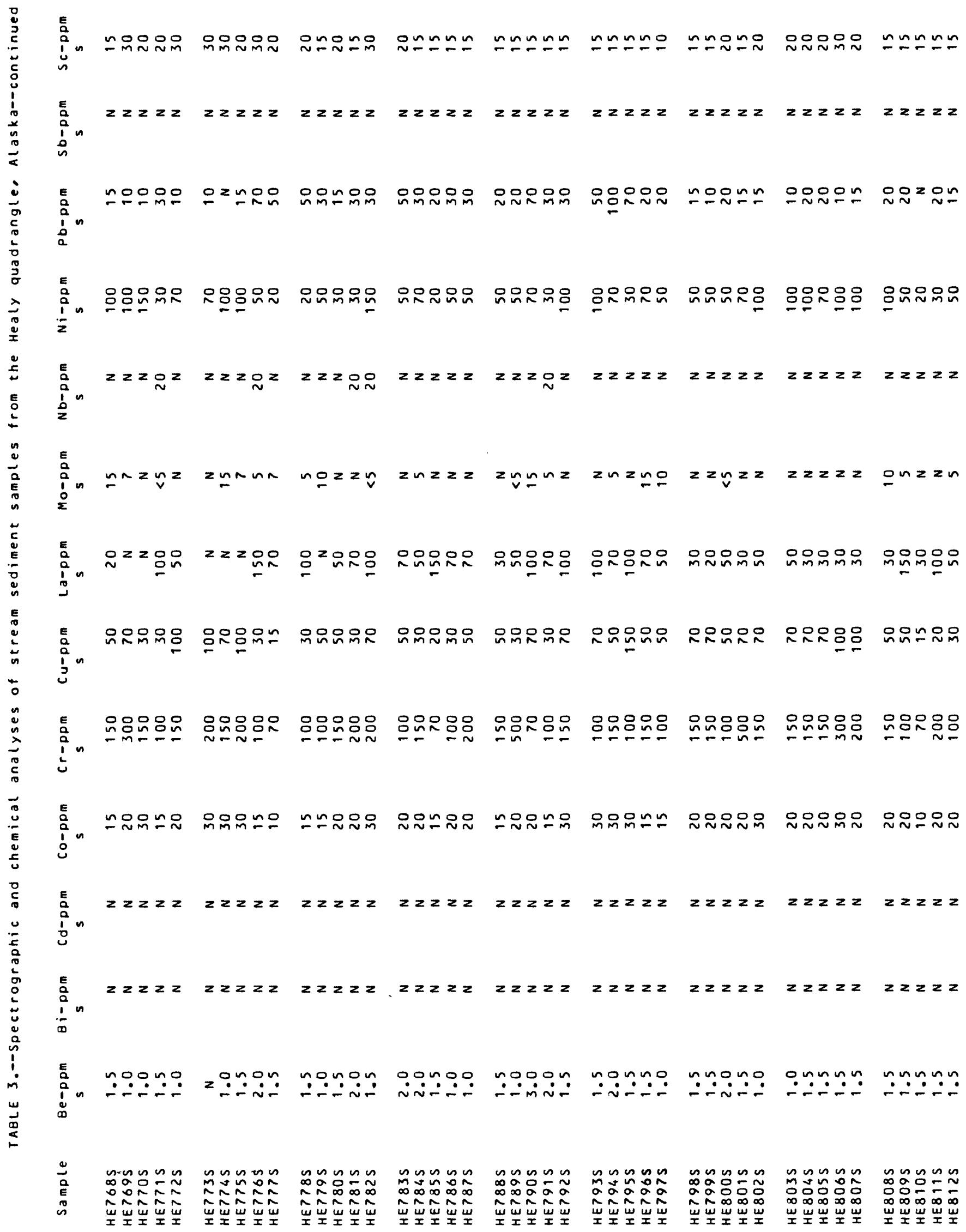


憵 产

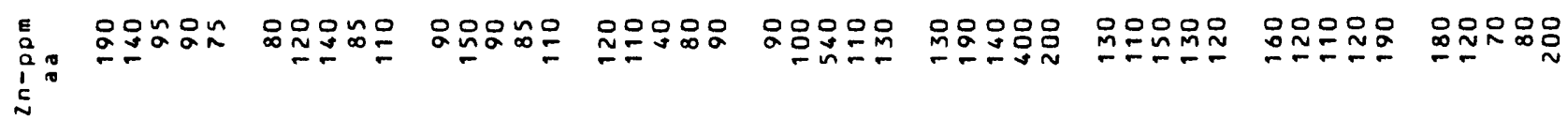

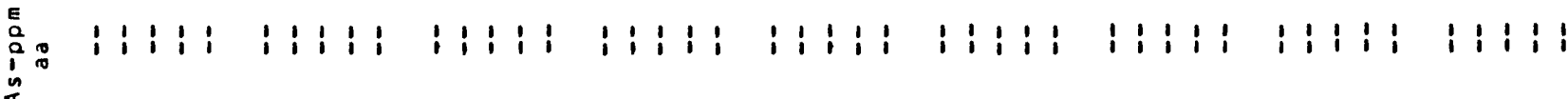
严

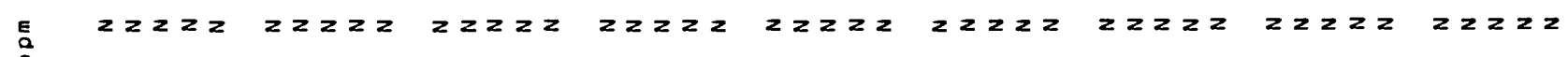
管

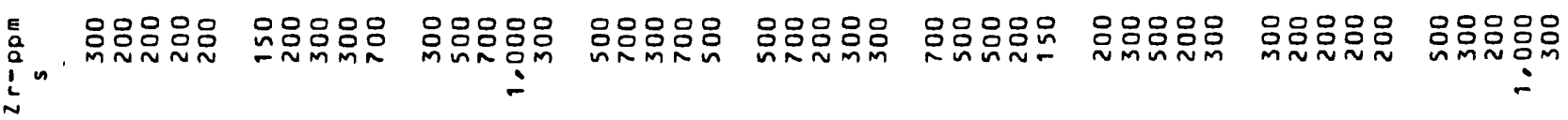

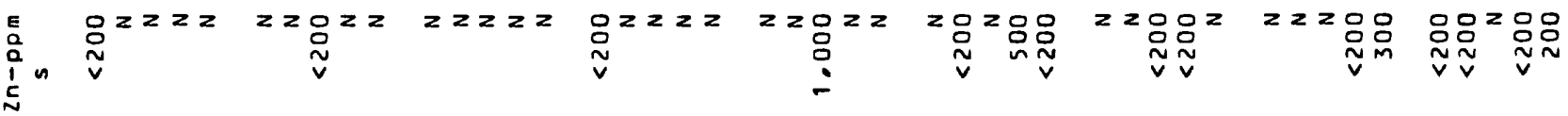

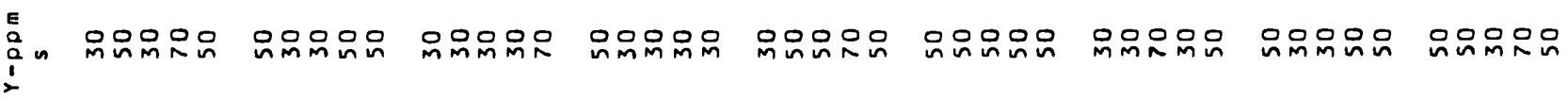

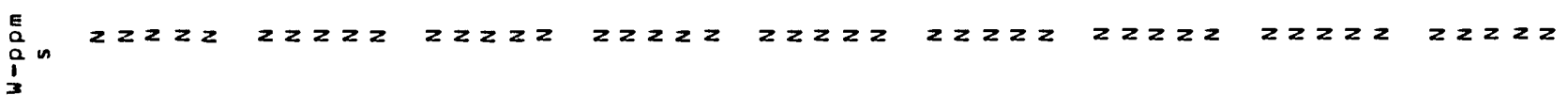

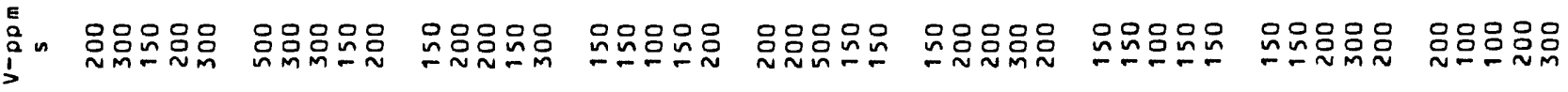

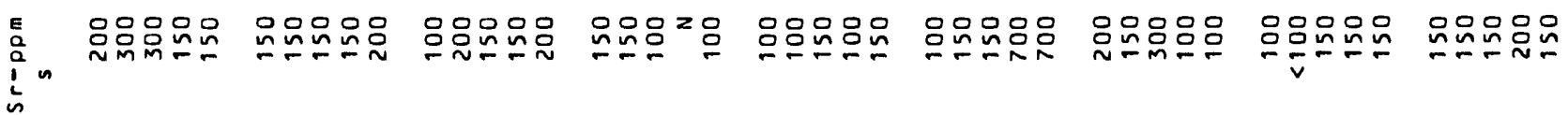

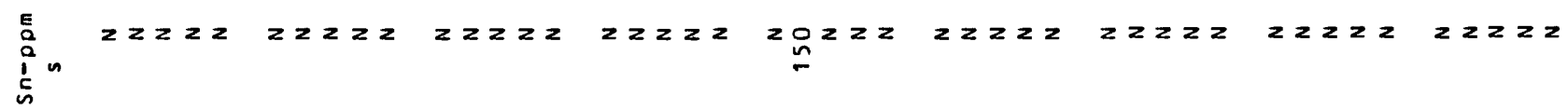

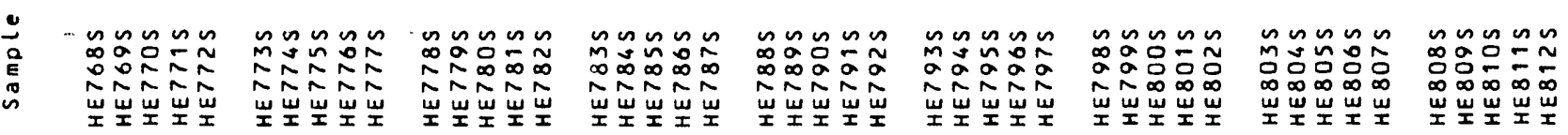




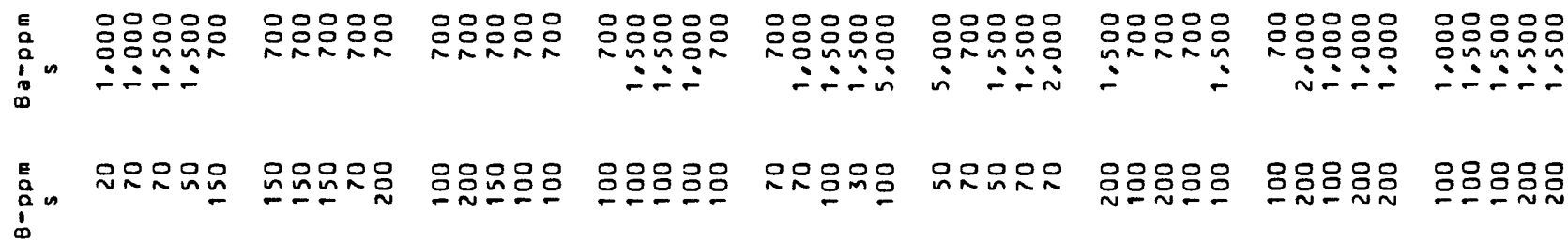

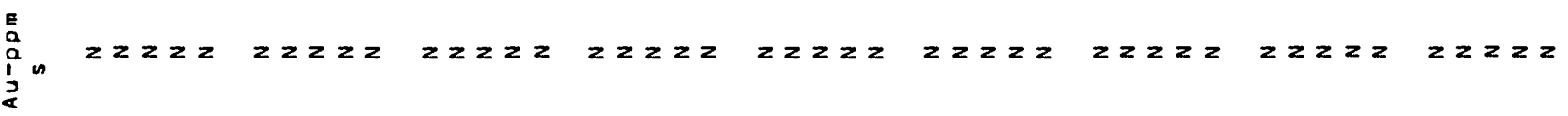

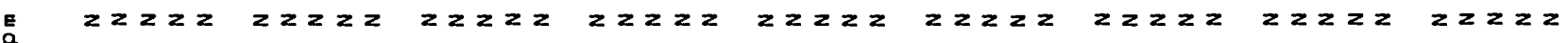
$i_{i}^{a}$ E
a
$i$
a

$z z z z z \quad z z z z \quad z z^{0}: z z \quad z z z z z \quad z z z ?$ ? $z z z z$

$z z \geq z z$

$z \geq z z$

$z z z z 2$

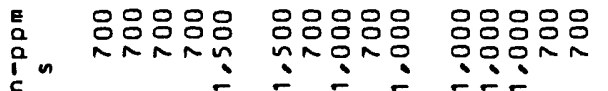

응응으 움음음

잉요

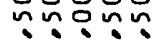

옴웃ㅇㅇㅁ옹

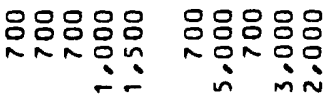

음옹음 ㅁํำ? $\underset{\dot{a}}{\dot{1}} \dot{i}$

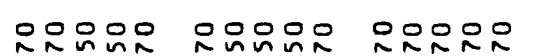

응ㅇㅁㅇㅇㅇ

응ㅇㅇㅇㅇ

은오은옹

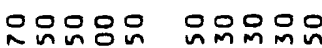

웅ㅇㅁㅇㅇㅇ

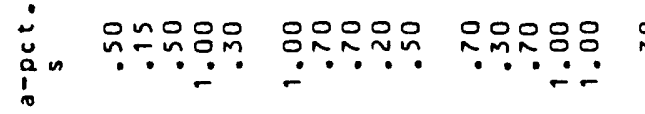

음은응

응응ㅇㅇㅇ 응응뭉ㅇ

오은옹응

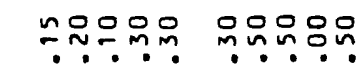

品n

$\operatorname{sos} 100$

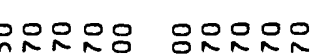

-. $\because$

$\because ?$ ?

웃응ㅇㅇㅇㅇㅇ

응옹온응 응응응응

응응우오

옥응ㅇㅇ 응이응

융응응응 $\therefore \dot{\sim} \because$ - inim $\dot{i} \dot{i}$.

$\because ? \div$

?.?กำ

$\because \dot{\sim} \dot{-}$

i 00000 00000 00000

00000

00000

00000

00000

00000

00000 s ninivin

ninivin

nininim

in invinis

nivinin

onnon

ño잉

ño요

Noㅇㅇㅇ

non

nono요

으요요

NニONM NMMMONM

miñ

o $\underset{\text { T }}{0} \sim 0$

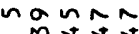

$\approx \infty m \tilde{m} \dot{\sim} \tilde{n}$

$\infty \backsim \infty \infty N$

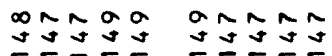

ñNก

$\because 00 \infty 0$

\& 유요

으윤 $\sin ^{\circ}$

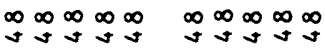

$\underbrace{\infty}_{0}+\infty$

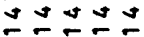

ンேンュン

$\sim 2 \pi$

$a \circ \infty \infty \infty$

$\underset{2}{2}+\infty$

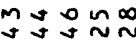

nonnn Nmnnn

ํำ

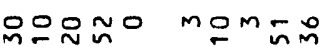

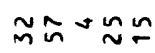

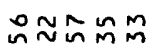

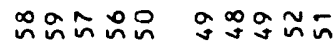
든ํํํำ

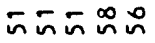

ถีะกี่ง

ơ⿱

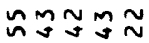

mo

$\infty$

$\infty \infty \infty a$

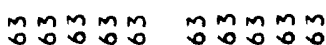

món

mom

món

mo mo

mŏ

드윰ำ

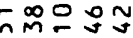

nnone non

$\bar{\infty} \frac{1}{\infty} \frac{1}{\infty} \frac{\infty}{\infty} \quad \frac{\infty}{\infty} \underset{\infty}{\infty} \underset{\infty}{N}$

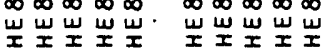

nก⿻上丨丶

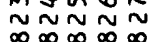

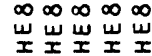

non $⿻ n$

NMmm mmMm

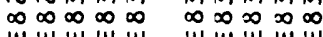

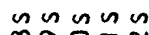

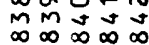

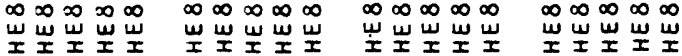

$\min _{m} n \operatorname{nn}$

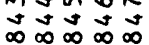

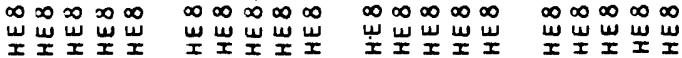

$\operatorname{nn} n \pi \tilde{N}$

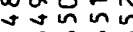

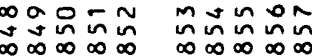

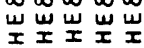




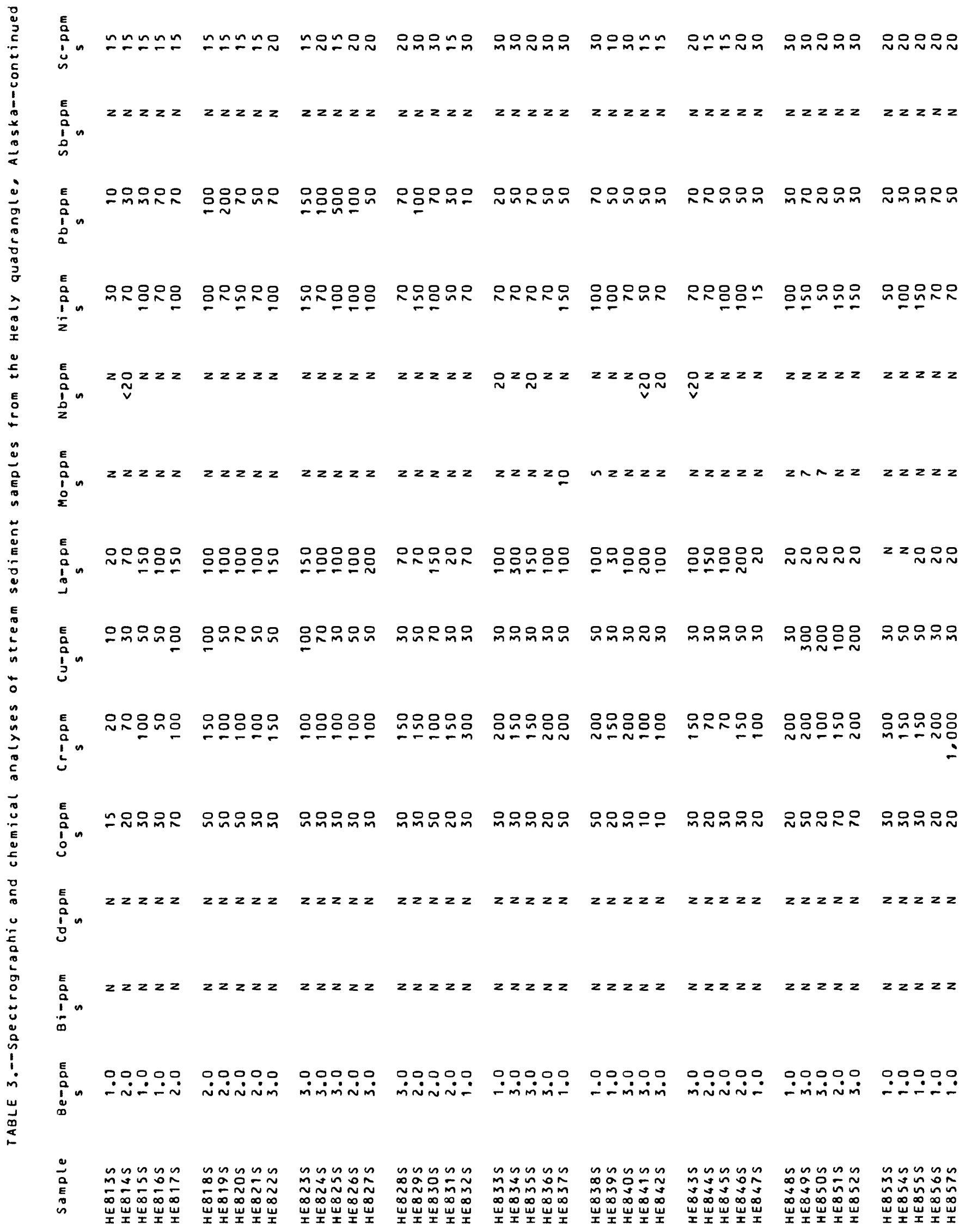


高

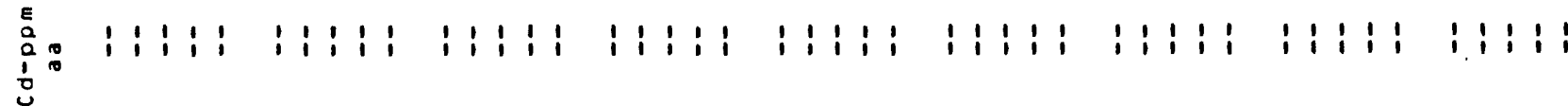

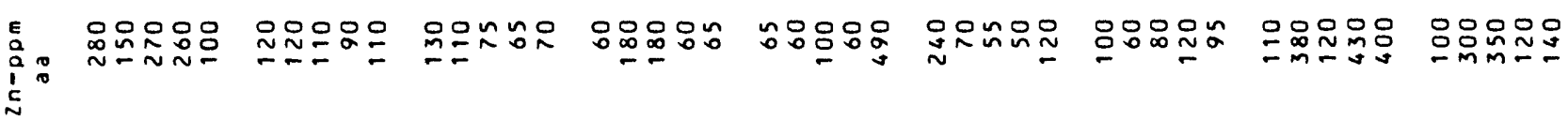

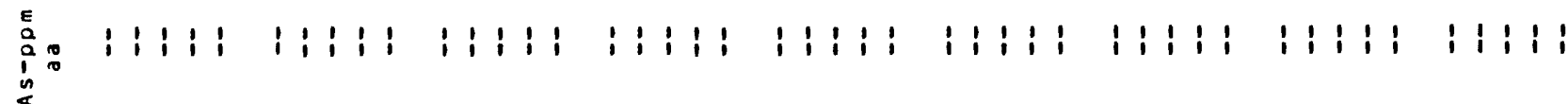
焉:

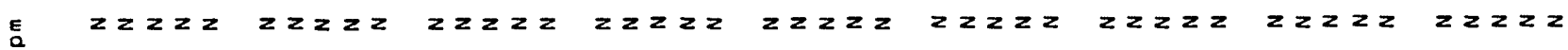
$i^{2}$

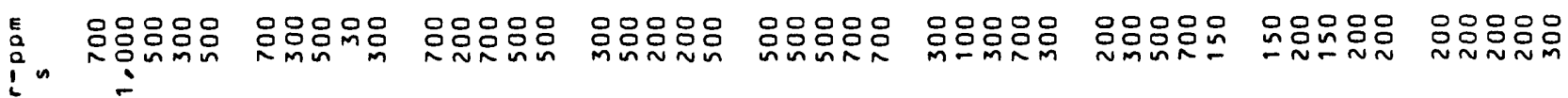

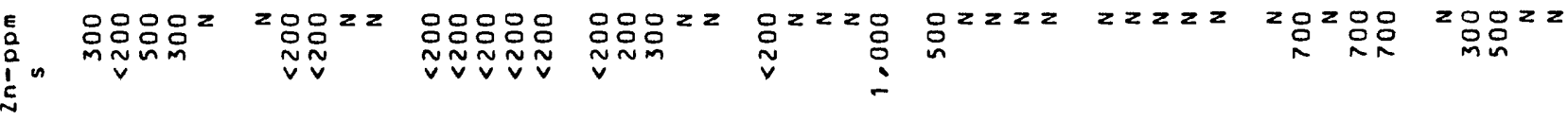

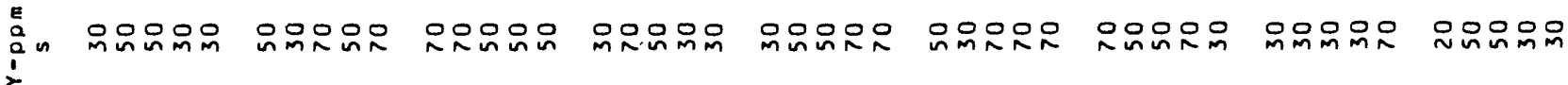
产

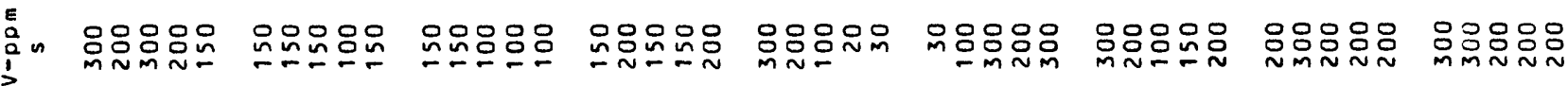

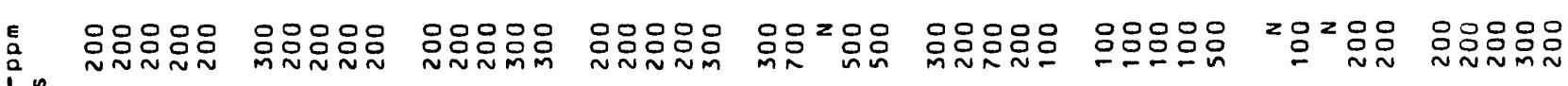
is

E is

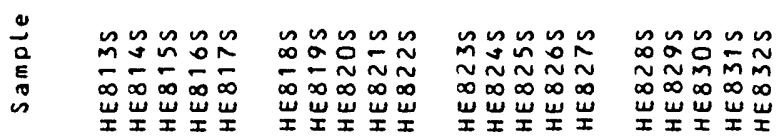

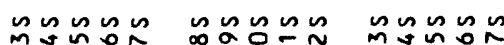
mmmm $\infty \infty \infty \infty \infty$

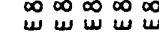




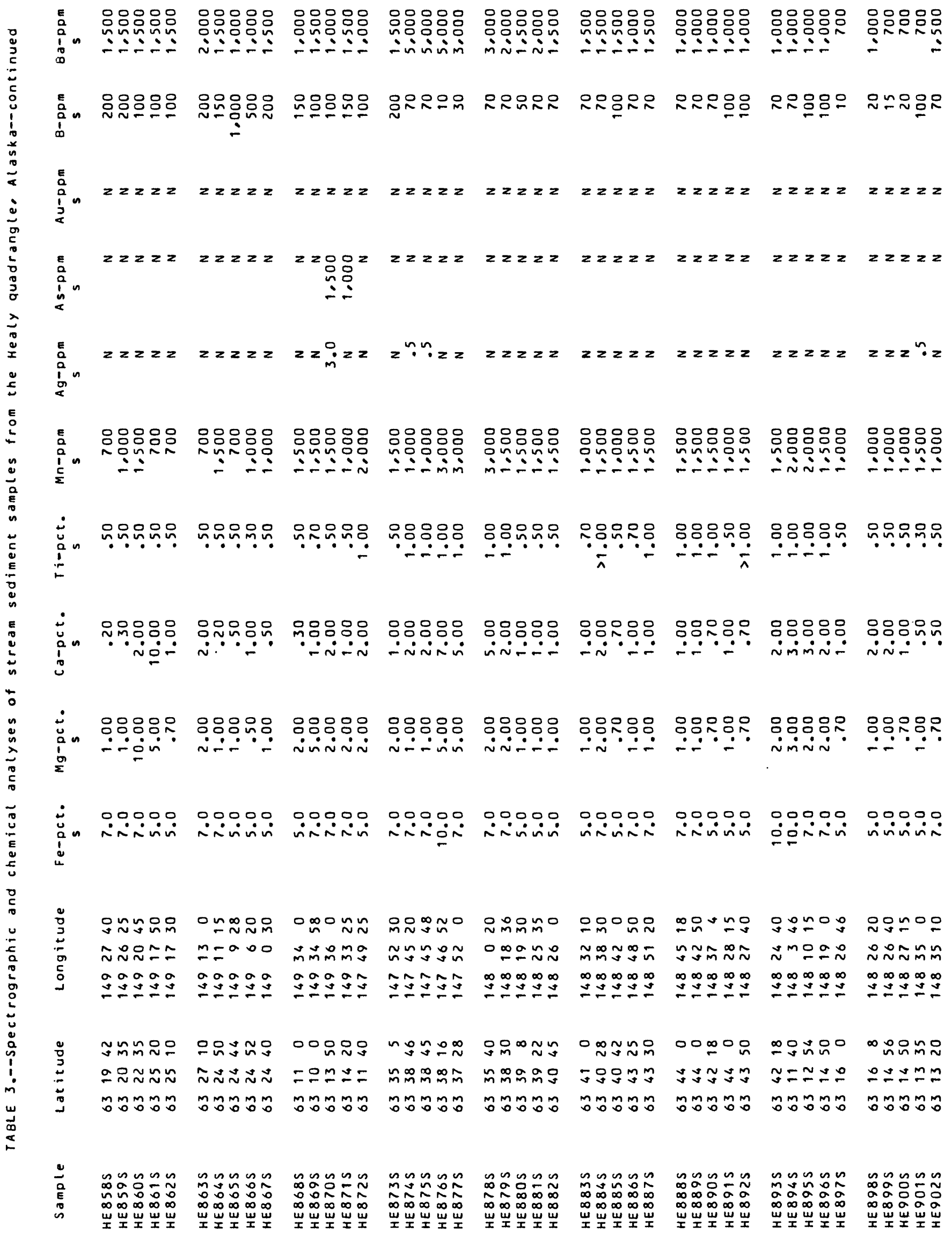




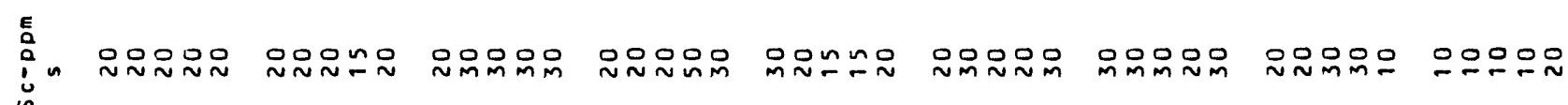

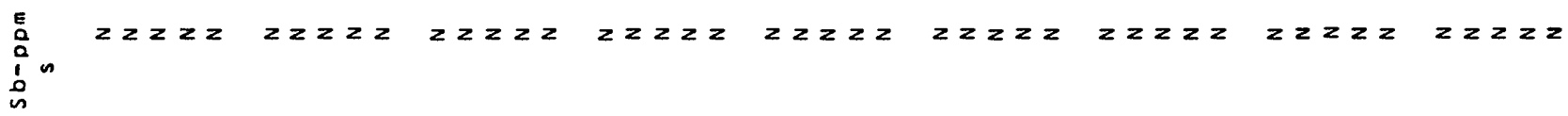

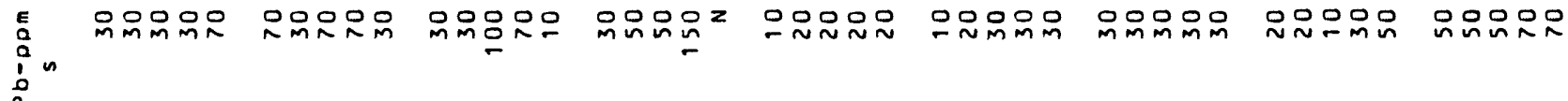

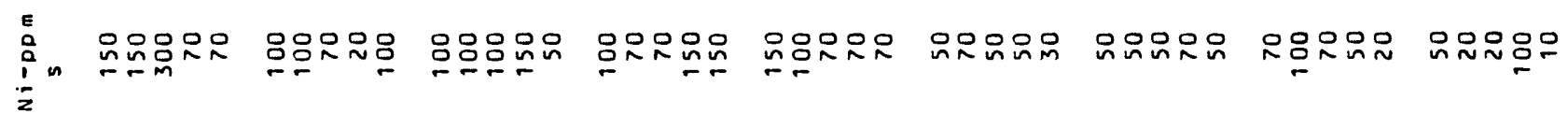

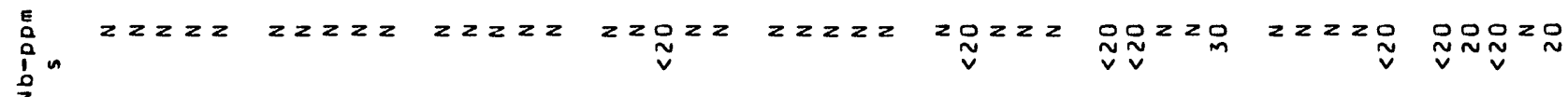
总

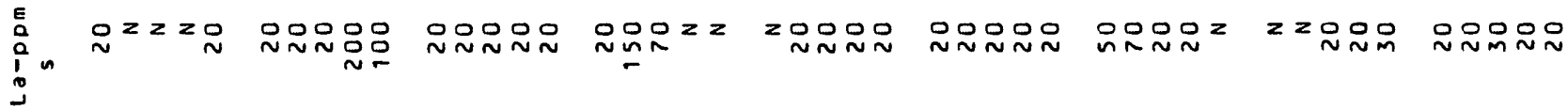

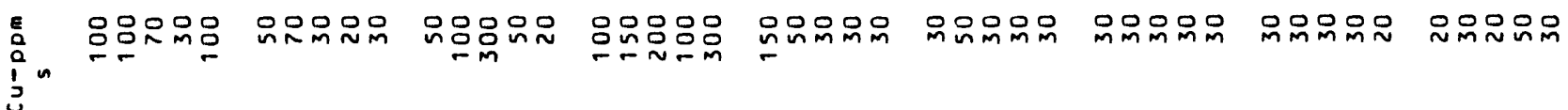

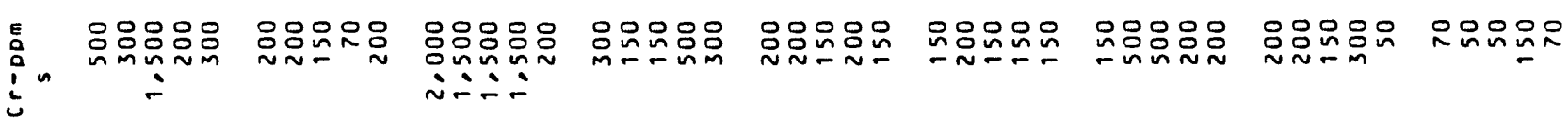

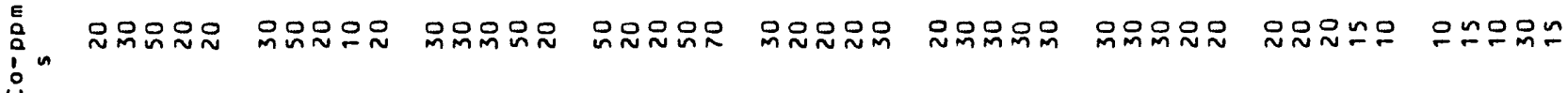

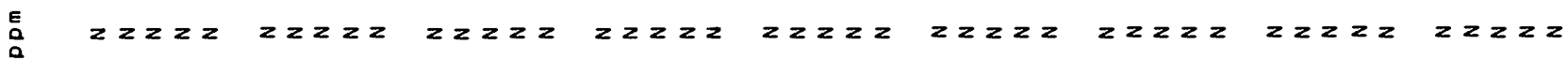
$\dot{j}^{n}$

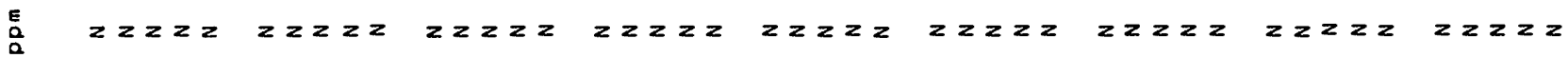
$\therefore$

!n

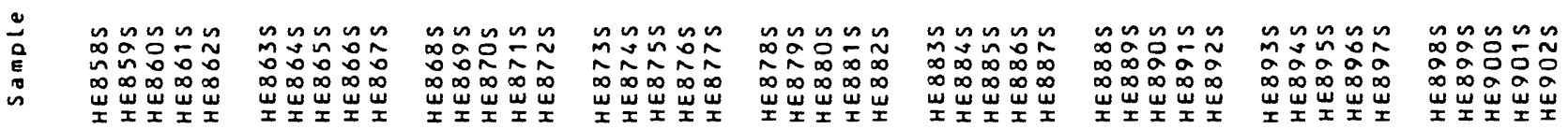




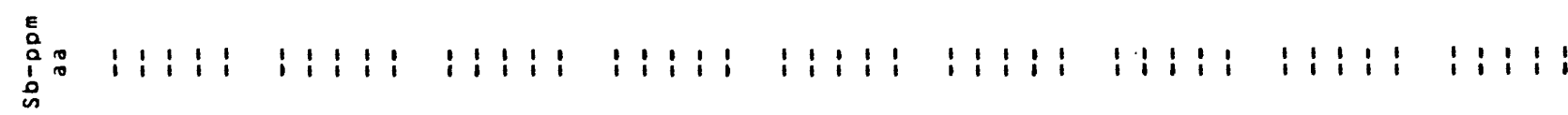

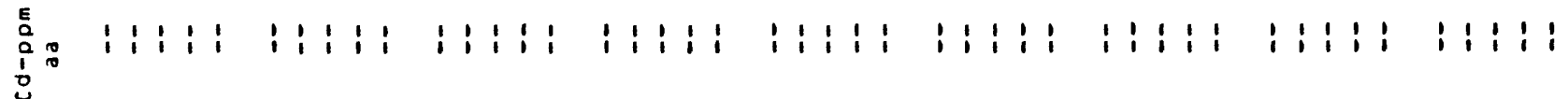

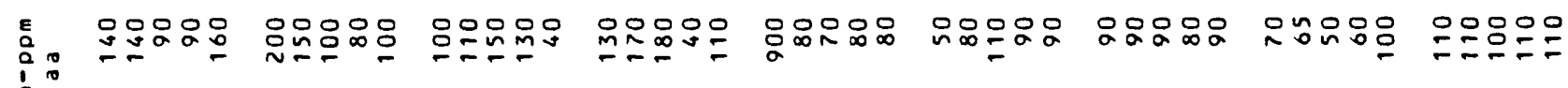
s

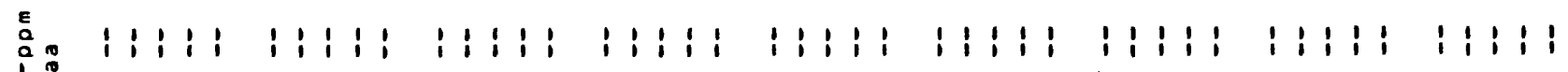
$<$

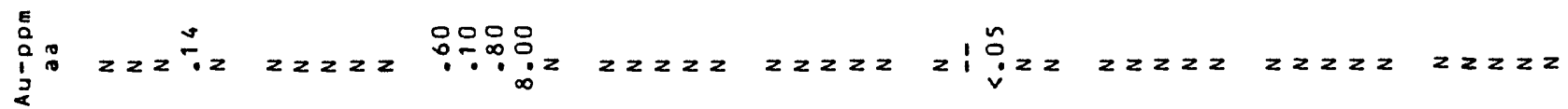

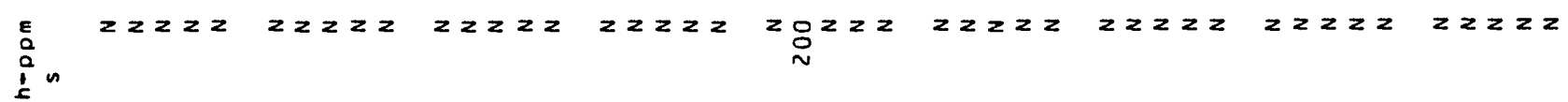

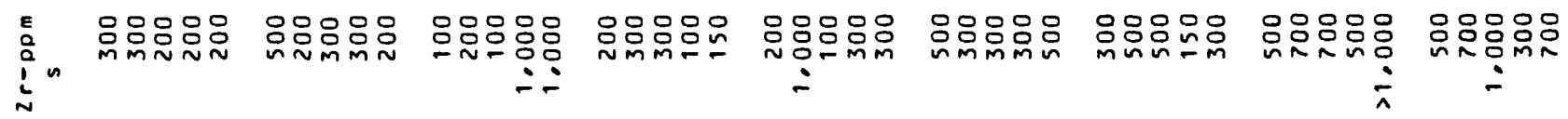

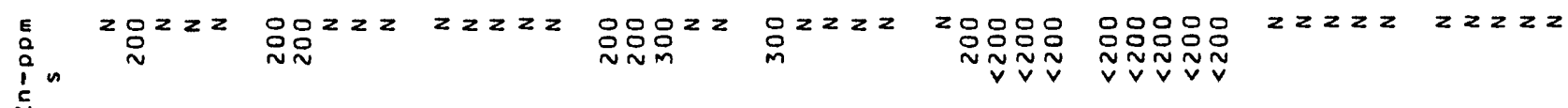

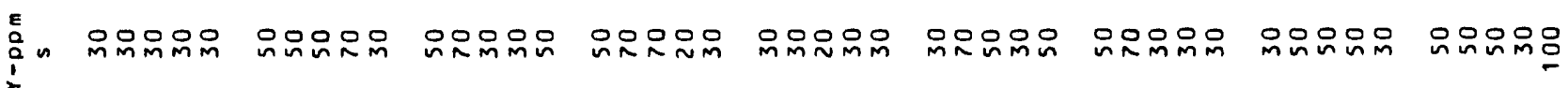
镸

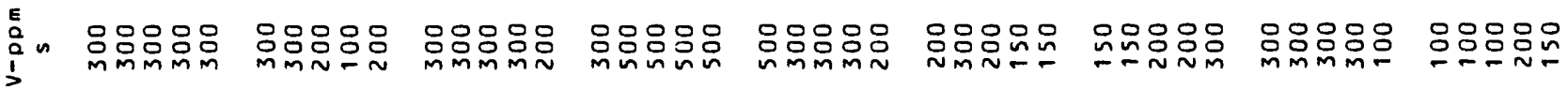

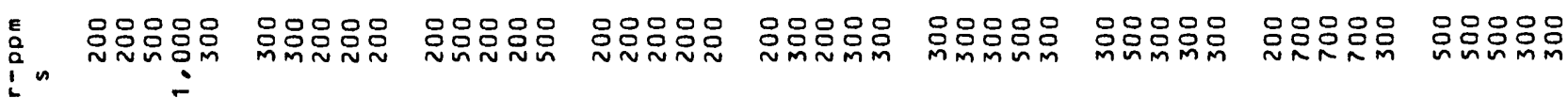
点

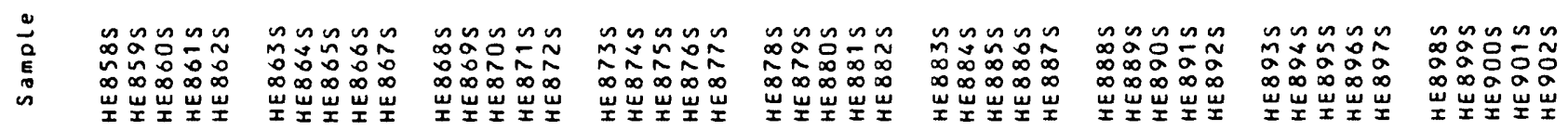




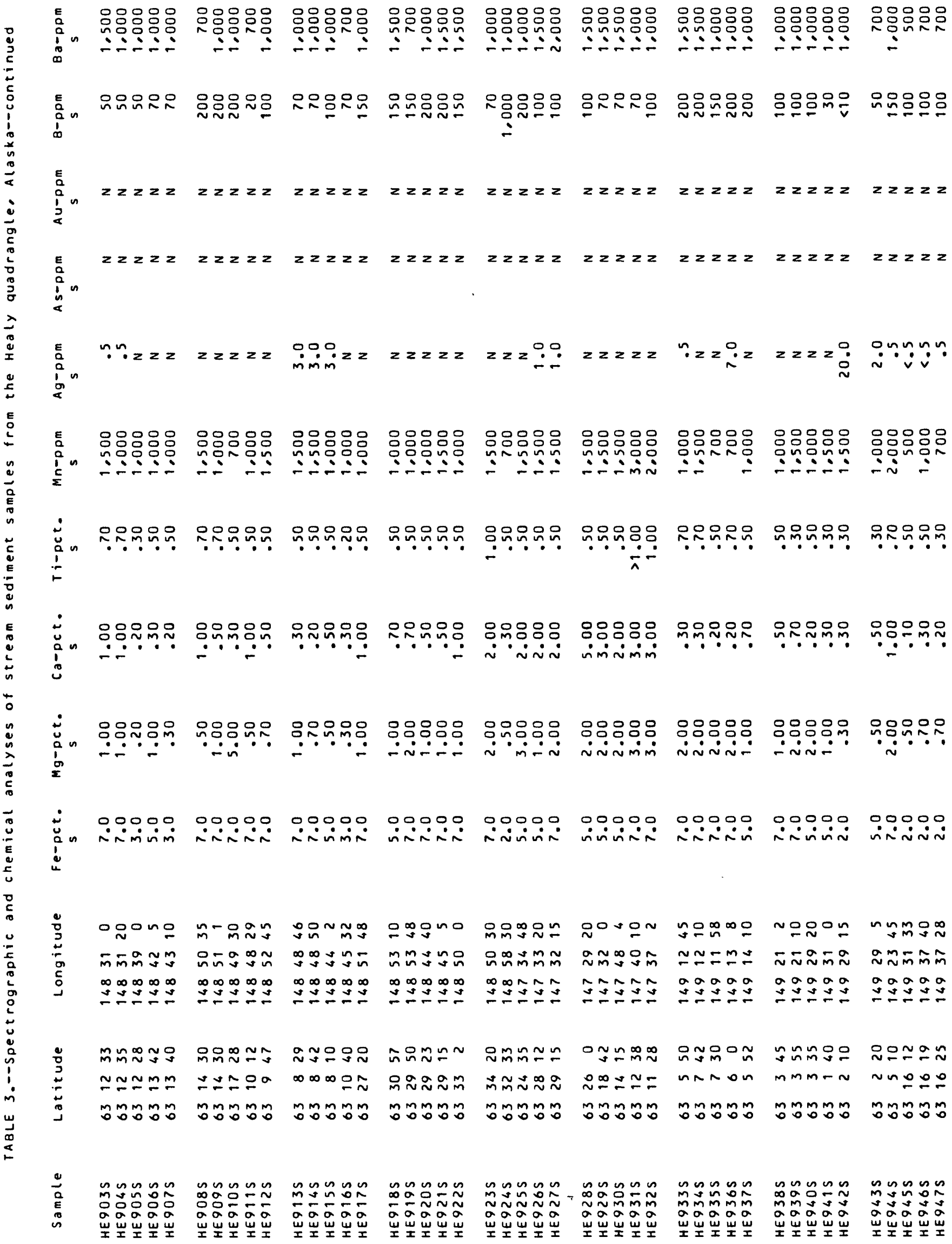




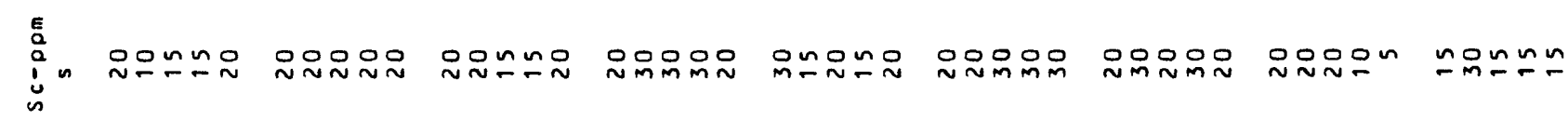
I

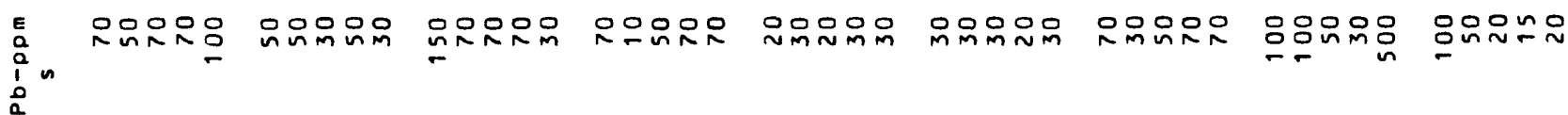

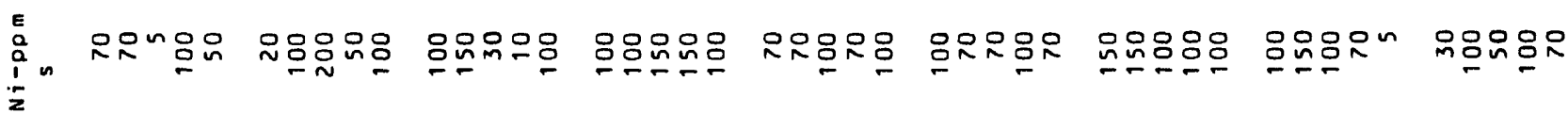

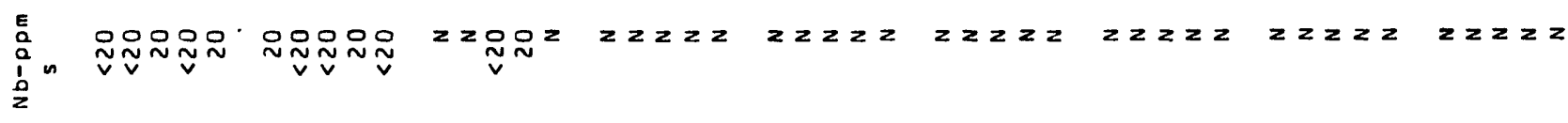

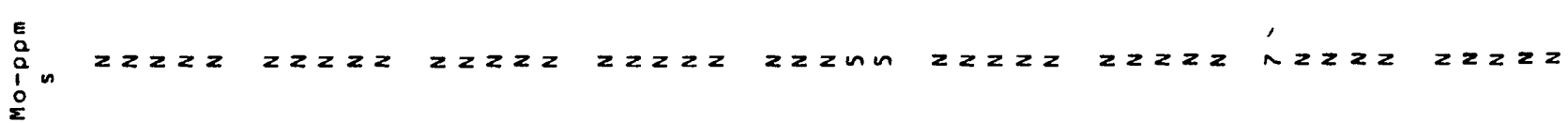

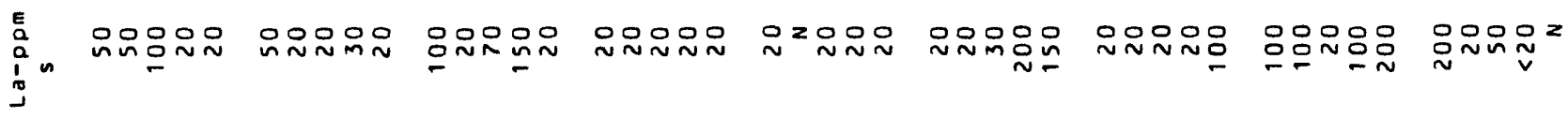

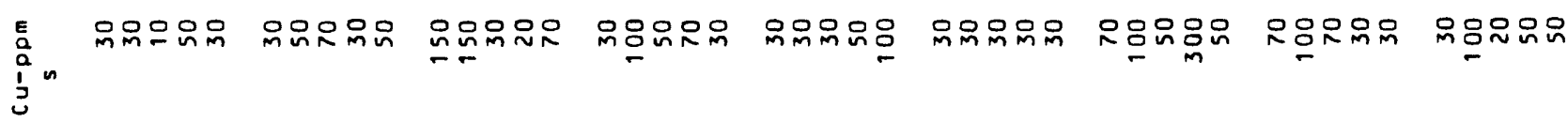

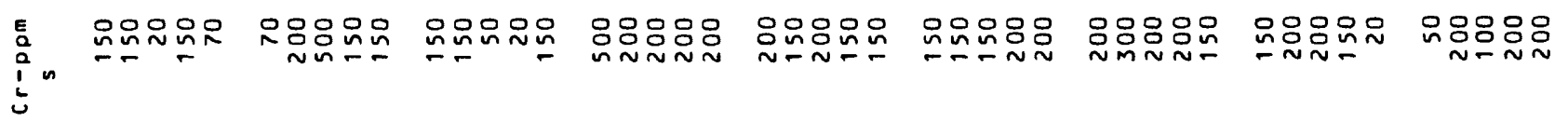

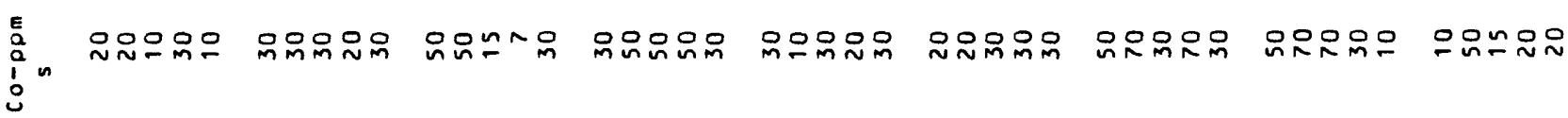

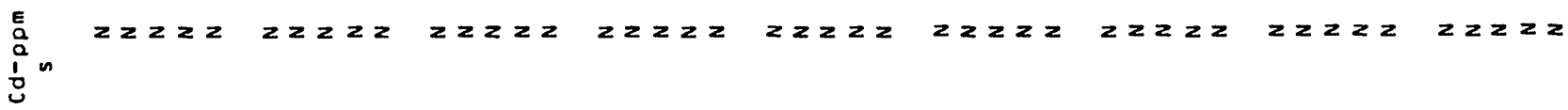

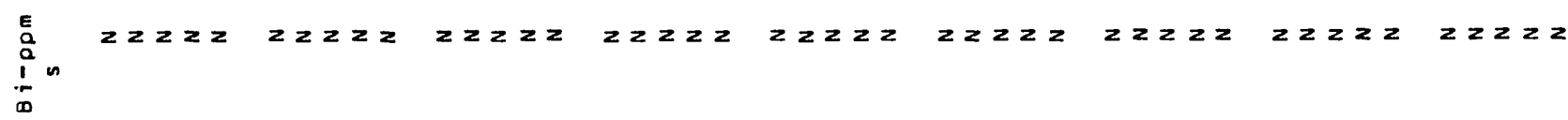
㒸

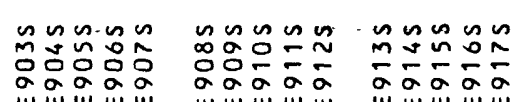

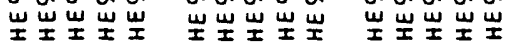

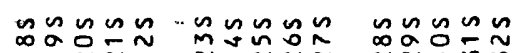

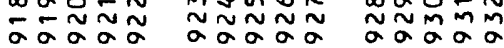

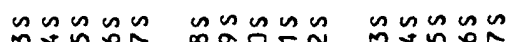

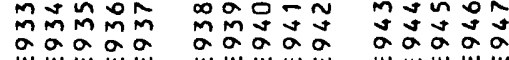

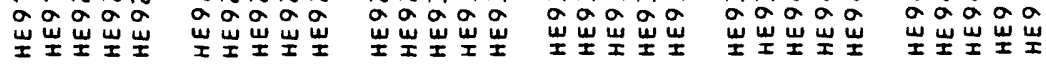




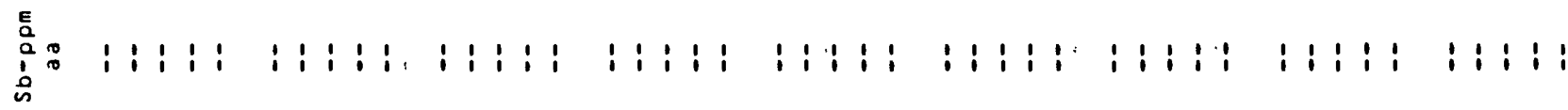

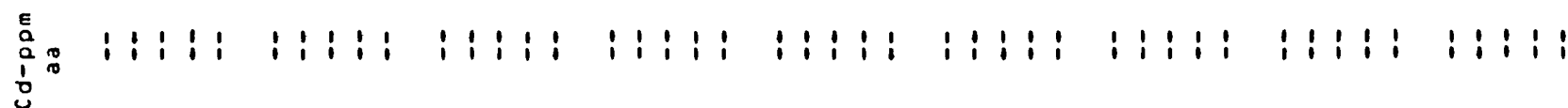

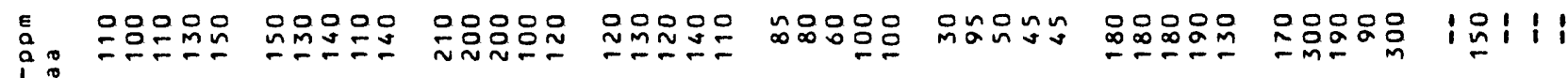
$\stackrel{1}{n}$

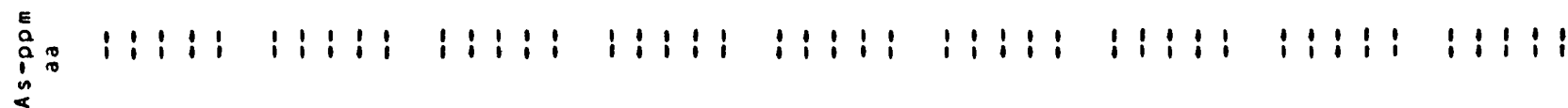

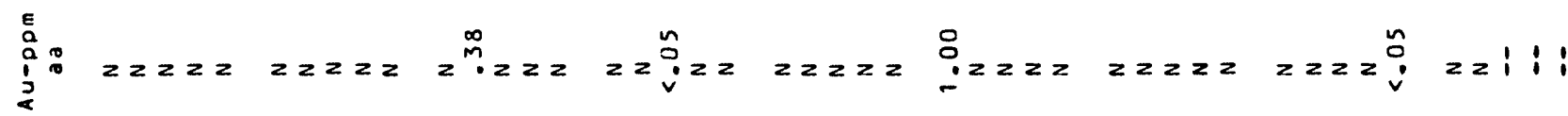

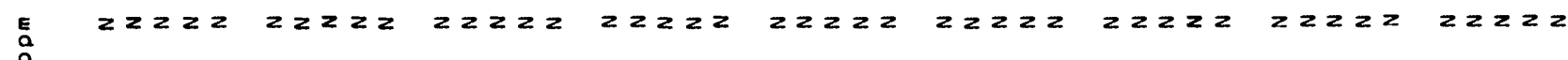

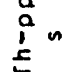

$E$
0
0
$\vdots$

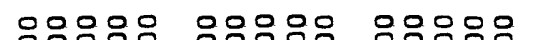

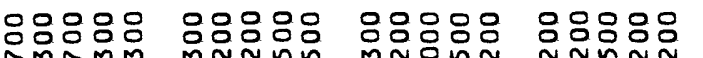

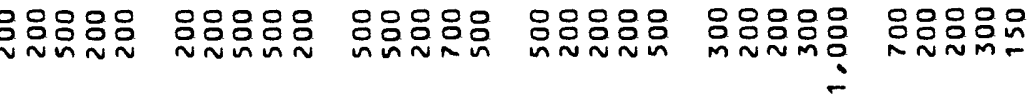

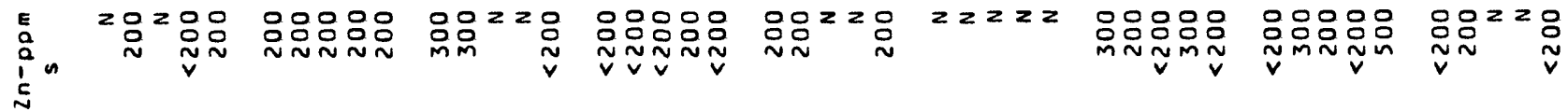

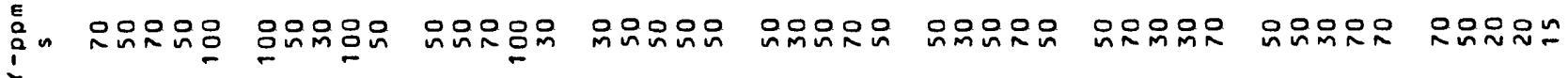

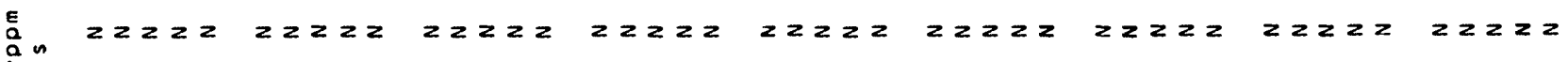
$\underline{3}$

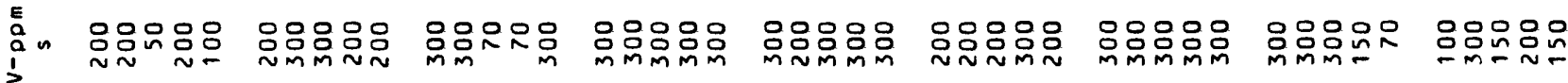

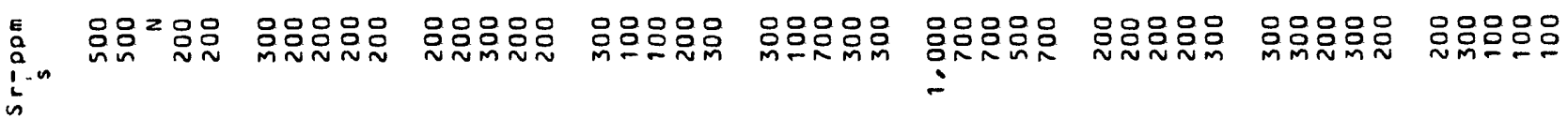

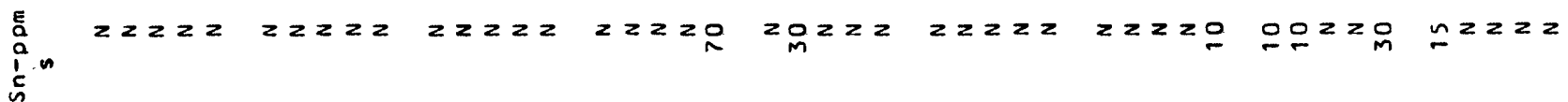

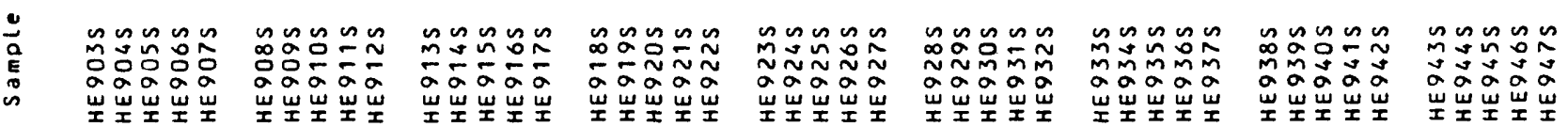




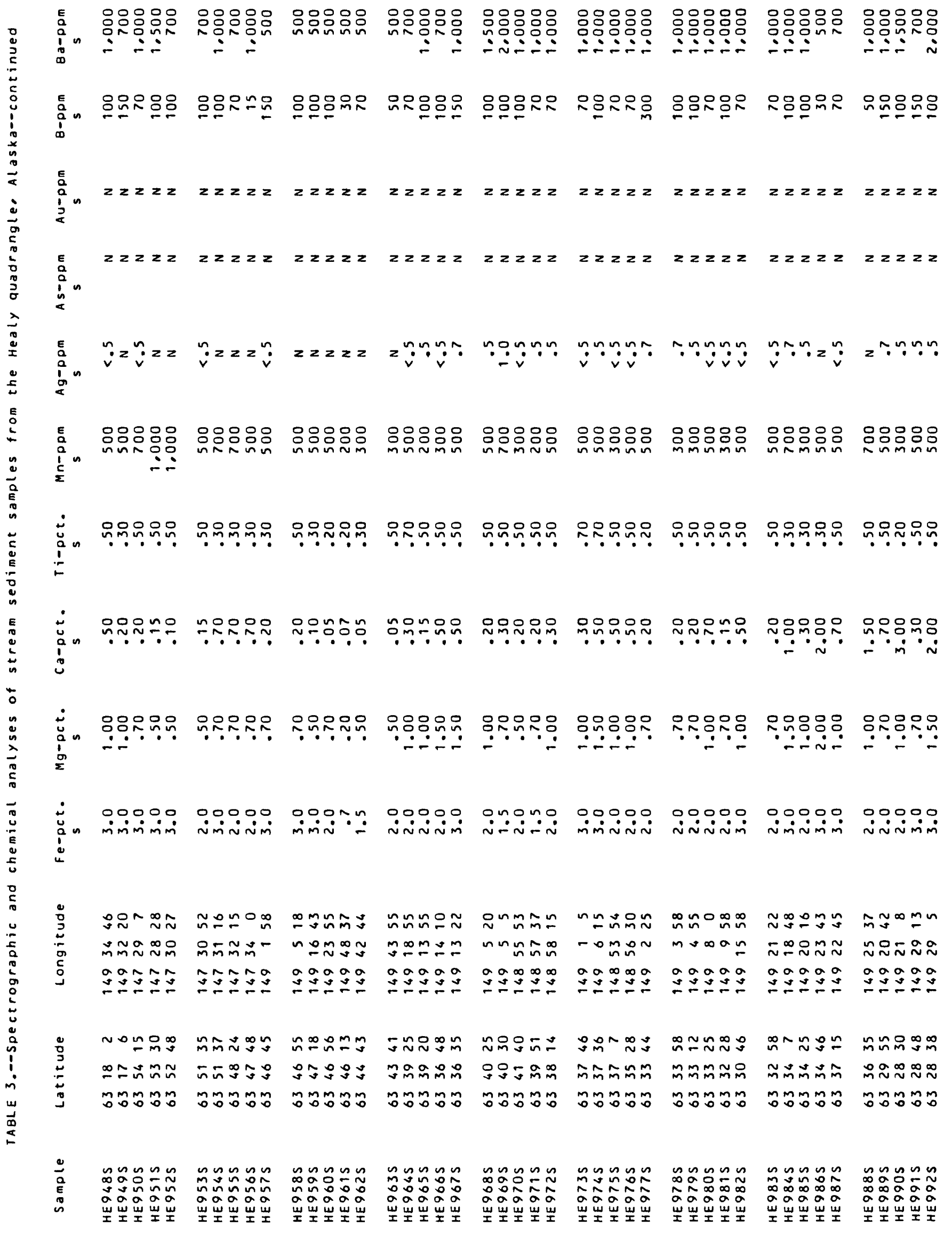




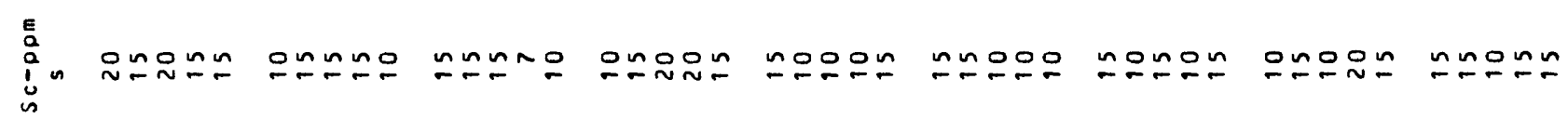

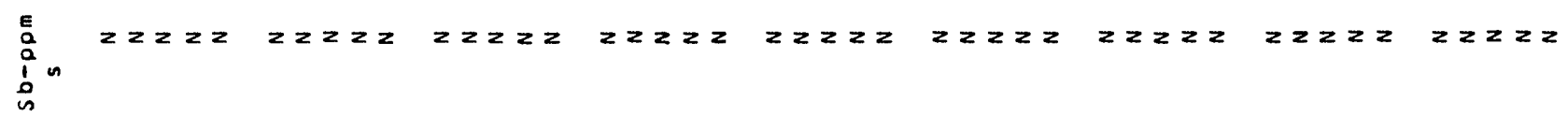

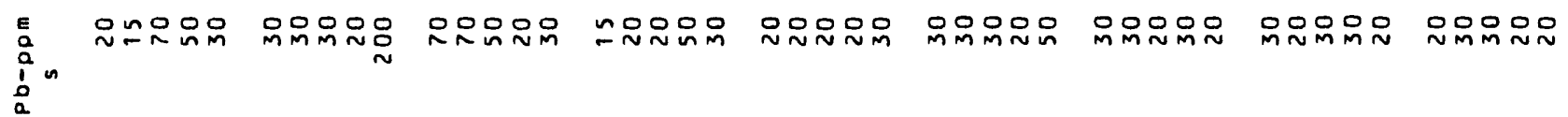

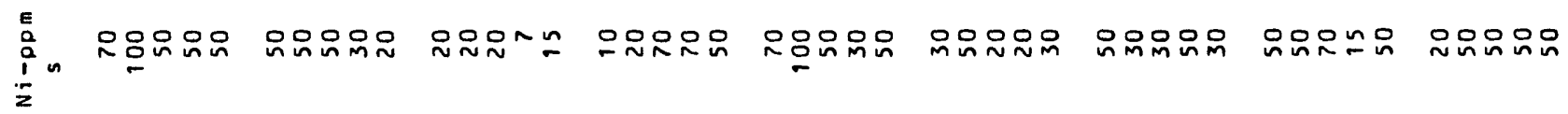

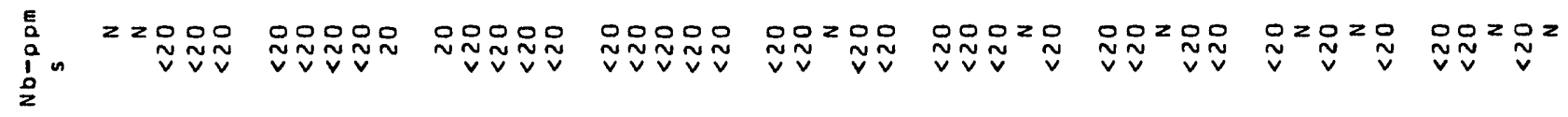

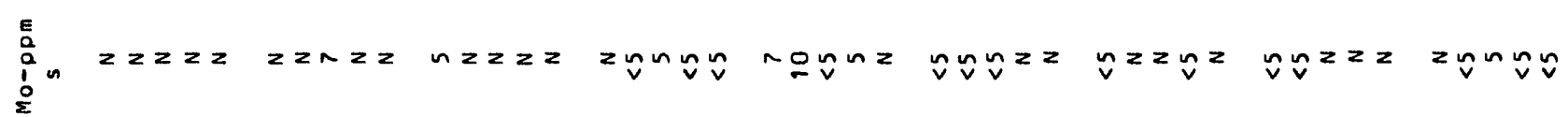

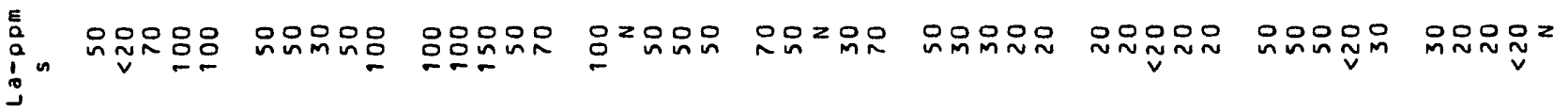

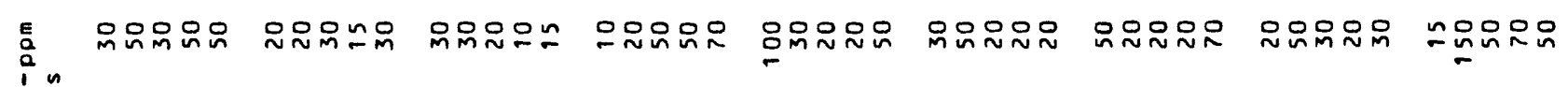

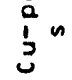

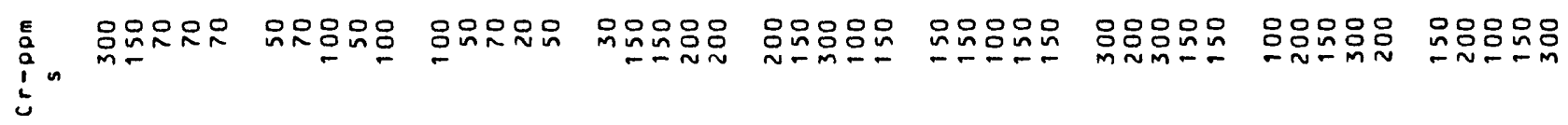

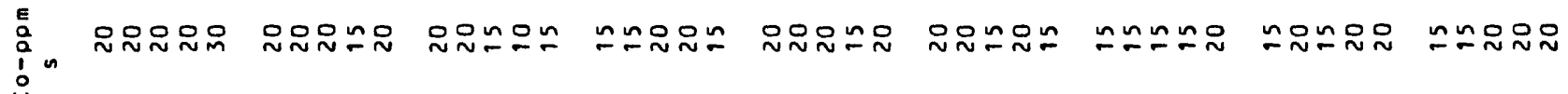

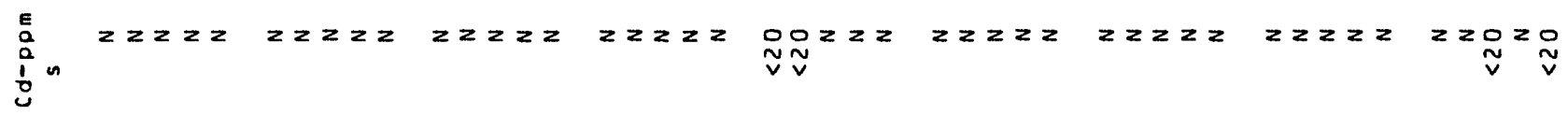

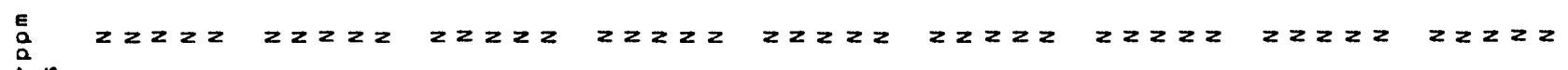
$\frac{1}{\infty}$

00000 0000n no000

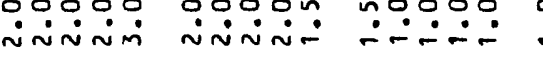

00000.0000000000

000000000000000

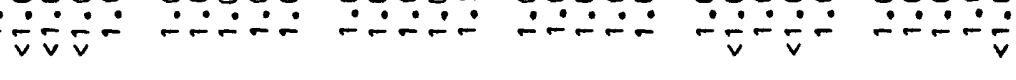

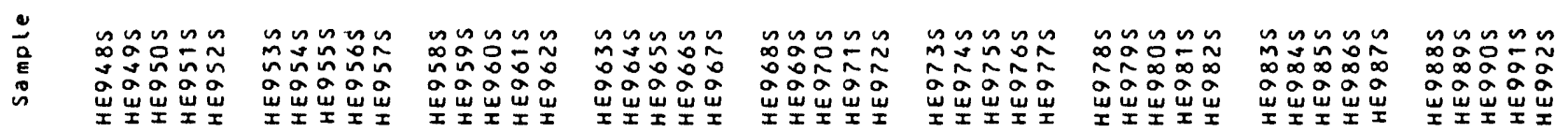




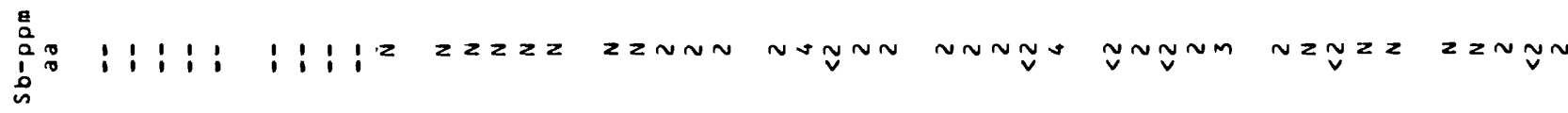

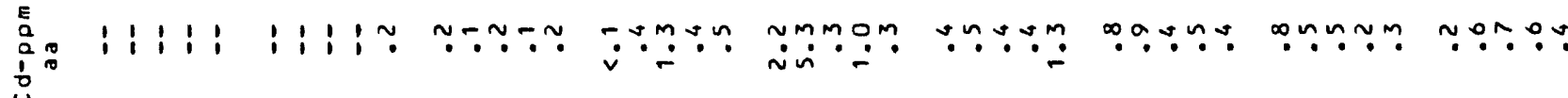

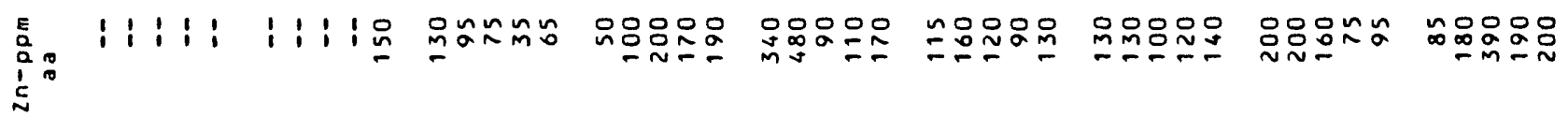

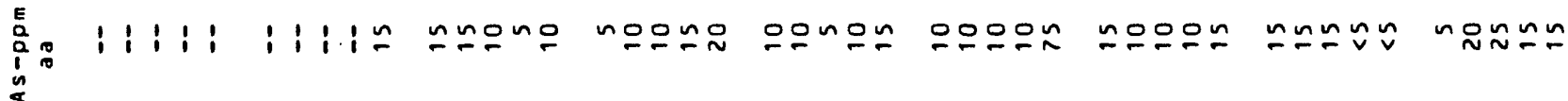

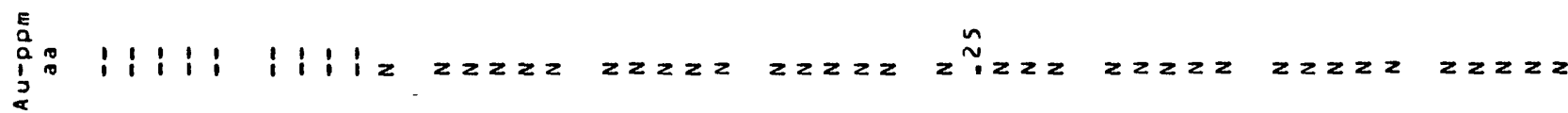

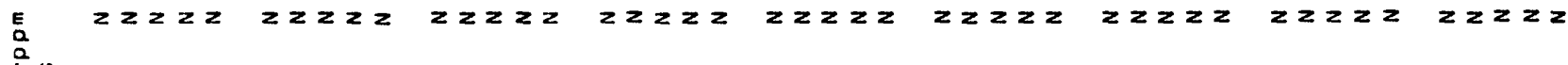
$\stackrel{1}{i}$

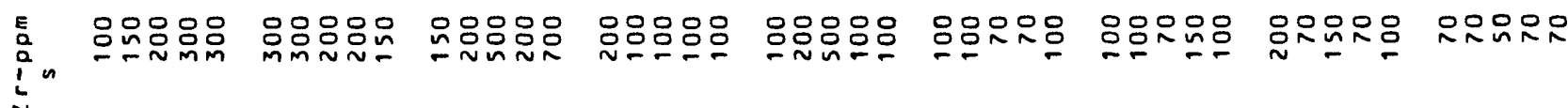

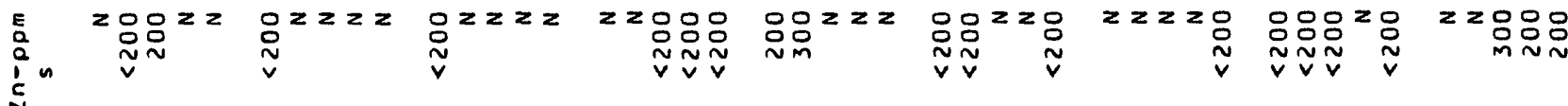

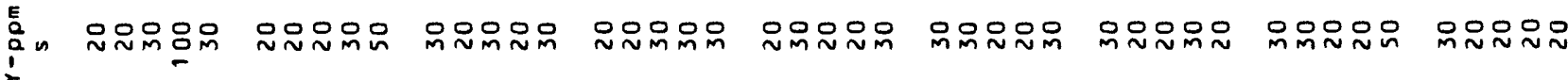

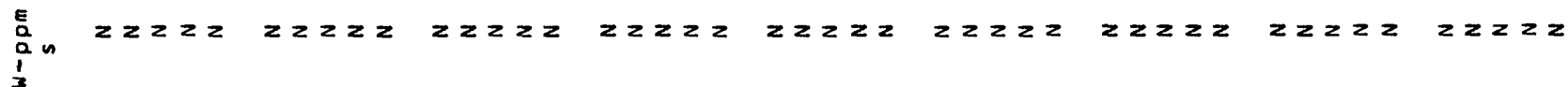

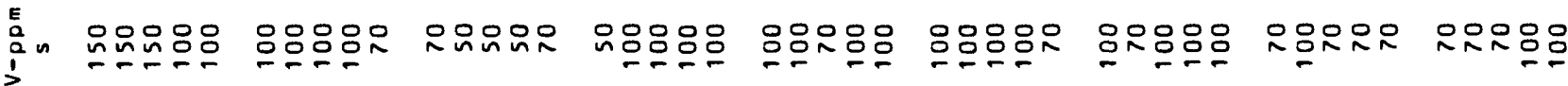

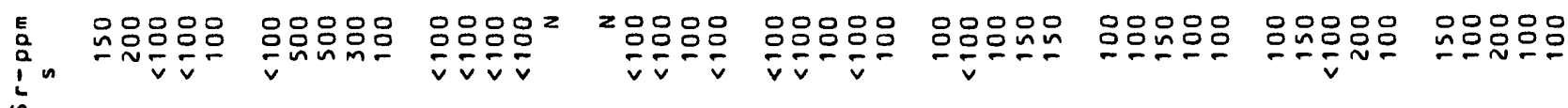
E⿱

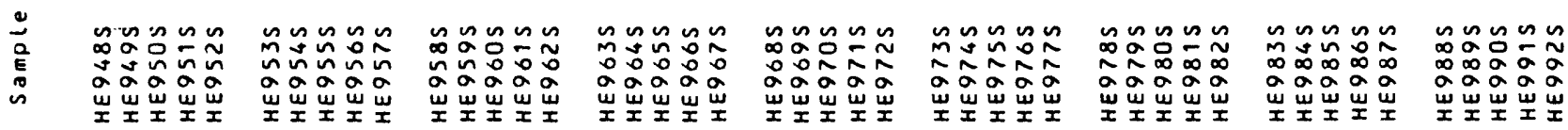




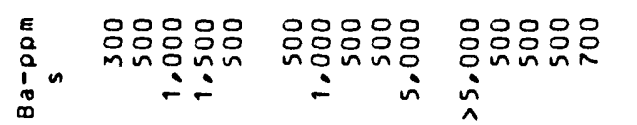

章n

$E$
$\vdots$
$\vdots$
$\vdots$
2

a

$z z z z 2 z z z 2$ zzzz

웃음요음

옹음음

은으뭉ㅇㅇㅇ

응읏우옷

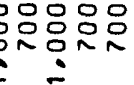

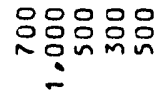

윳음욤요

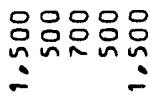

응ㅇㅇㅇㅁㄴ.

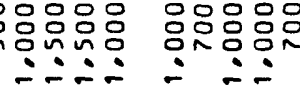

000

응오옹

음응응우

으으뭉ㅇㅇㅇ

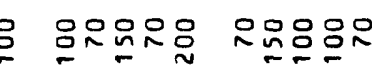

10

$z z z z$

$2 z 2 z$

$z 2 z z$

$22 z 2$

$z 2 z 2 z$

$z 2 z 2 z$

2222

$2 \stackrel{0}{\sim} 222$

品克

$22 g^{2}$

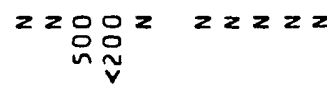

$\sum_{\substack{a \\ a^{\prime}}}^{E} z z^{n} \cdot z^{n}$

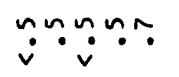

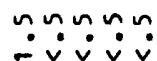

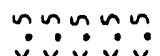

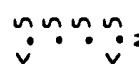

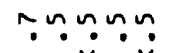

กุกnn

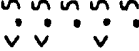

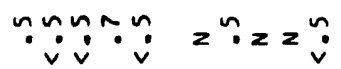

竞

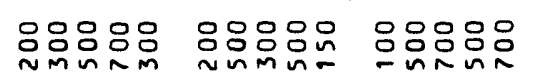

응음응응

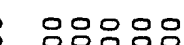

응

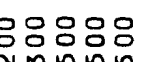

음용ㅇㅇ

음음웅

음 움음욤요

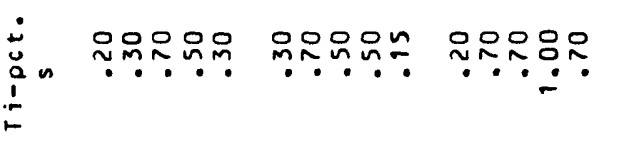

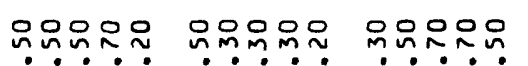

윰요욤요

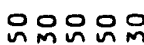

운온유모.

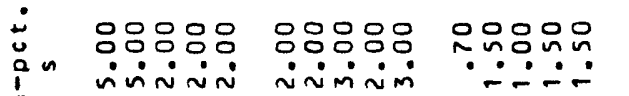

응응유움 음음응음

miñ.

$\because \because 90$

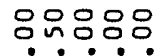

iंvivi

응응응

moㅇ․․

뭉ㅇㅇㅇ

웅음ㅇㅇㅁ i

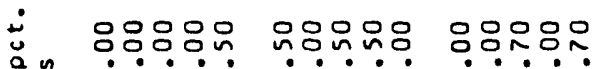

$\because \because \because \because$

$\therefore \dot{\sim} \therefore \therefore \because$

응응용응

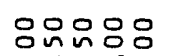

응요욤요

$\therefore \therefore \therefore$

$\therefore \because \therefore$

$\therefore \dot{\sim} \div$

응응용응

웅ㅇㅇ음

-ோ-

$\because \because \because$

옹음음

on

0000000000 落n

iniminim

inimin

00000

0000000000

0.0000

00000

00000

00000 nivin जinmini

iniminiv

miñi

inimimin

$\bar{m} ニ \tilde{n} \sim \tilde{m}$ mmon

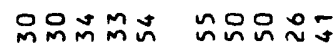

agag a

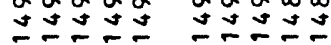

๓กำ

ตㅇำ

$\infty_{\infty}^{\infty} \infty \infty \infty$

ษささささ

응ㅁㅇㅇ $\sim 000$

$\stackrel{\sim}{\sim} \sim \tilde{\sim} \sim \mathcal{\sim} \sim \sim \sim \tilde{N}$

mMmmm

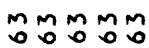

으으요

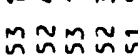

ติำดัด

웄웅응

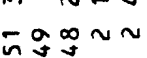

mmmmm$$
\text { nn }
$$

nทังทั

mmin $=$

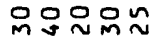

annun

은으윰요

nUON

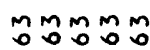

ตุำตำต

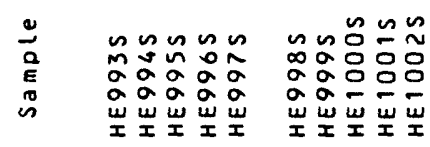

ตับูณณ 응응응

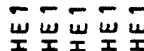

ณุ็นะณ 으응

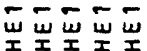

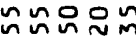

mmmmm

$\sim$

$=$

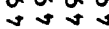

Dom

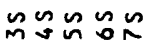
อ̄ฮ̄ó 뽚뽏

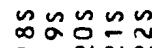
โอบกัก

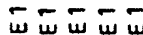

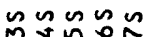
ก ก $\tilde{0}$ 으응응

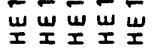

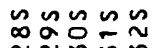

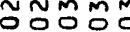

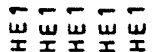

กะำณ

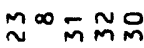
araa ปさンさす

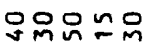
man ตุำตำ 


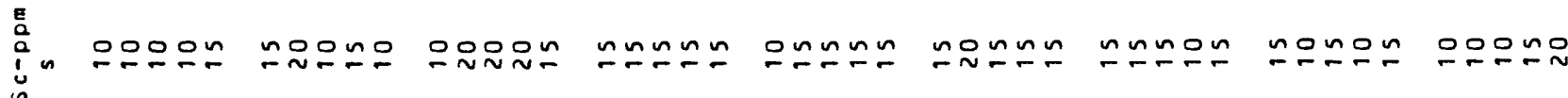
E
合
员

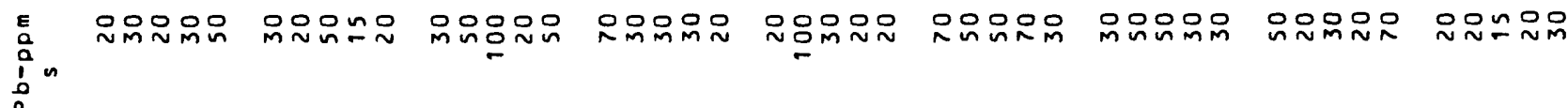

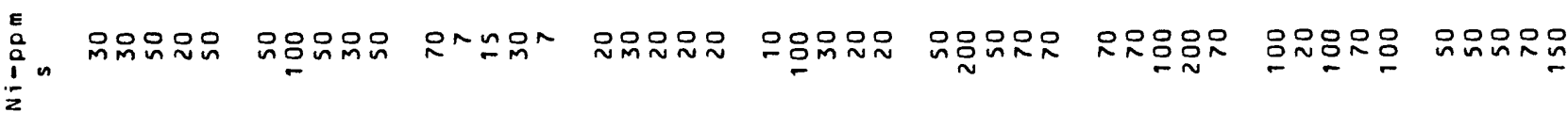

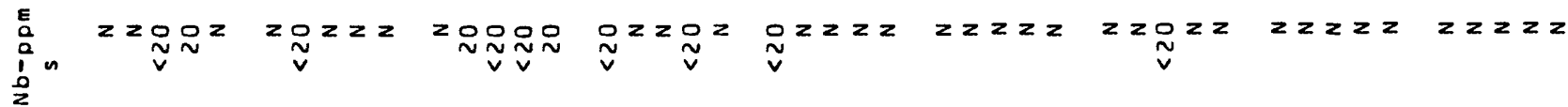

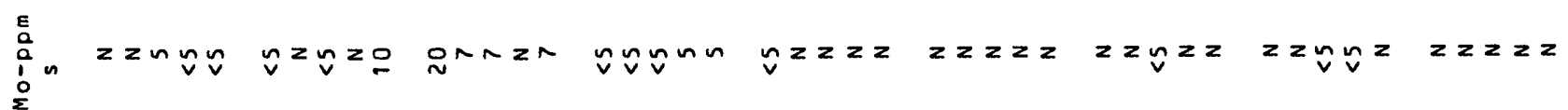

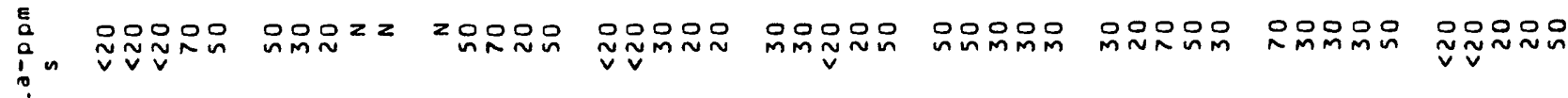

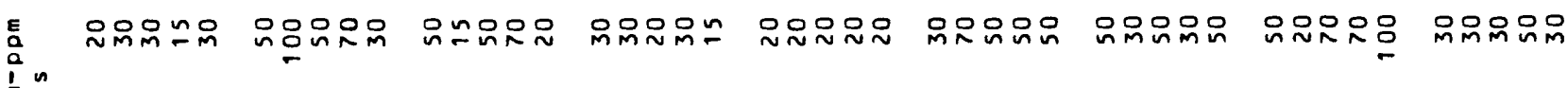

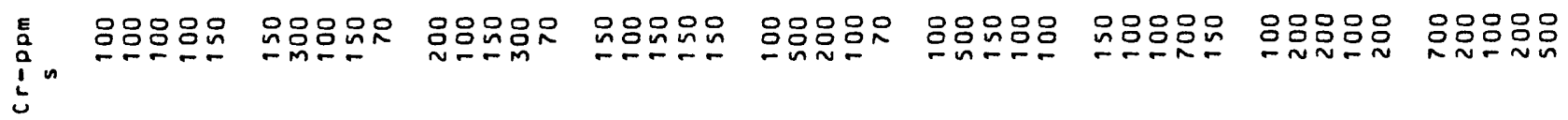

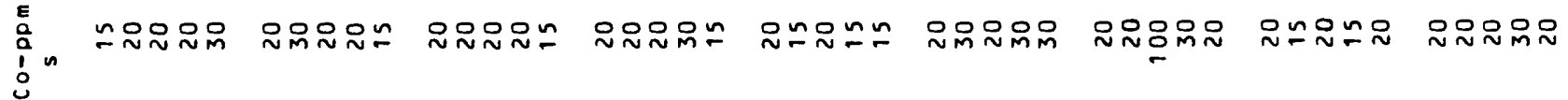

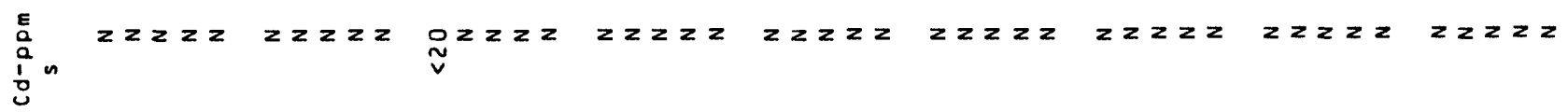

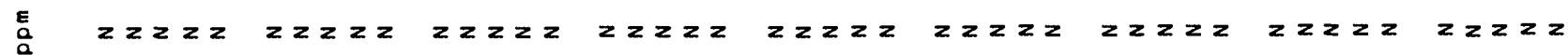
$\frac{1}{n}$

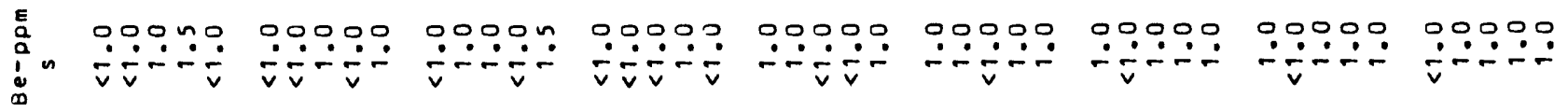

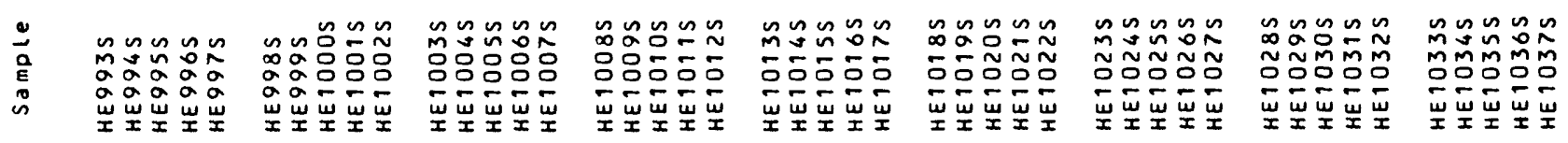




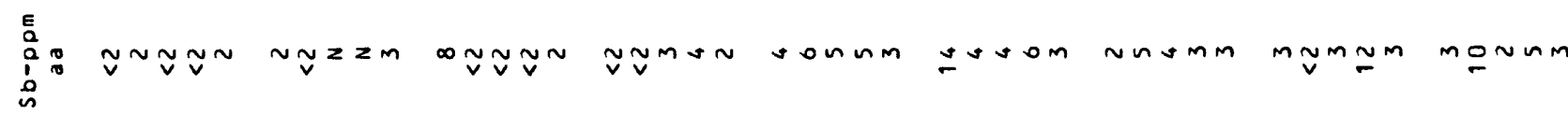

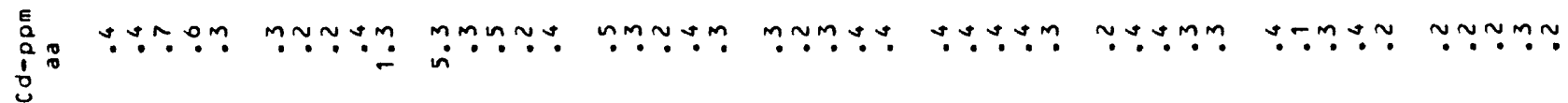

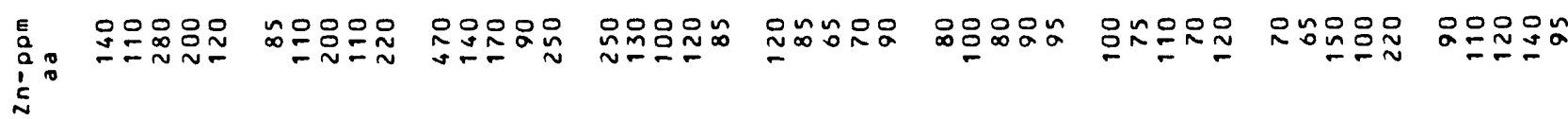
E

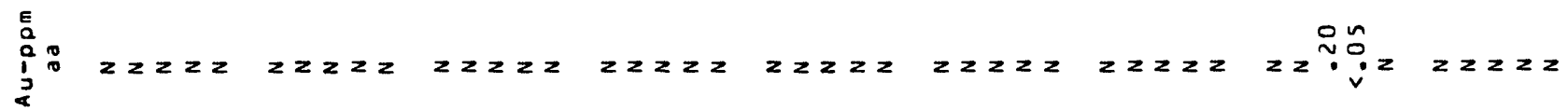

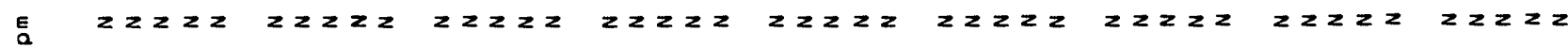
$\sum_{i}^{a}$

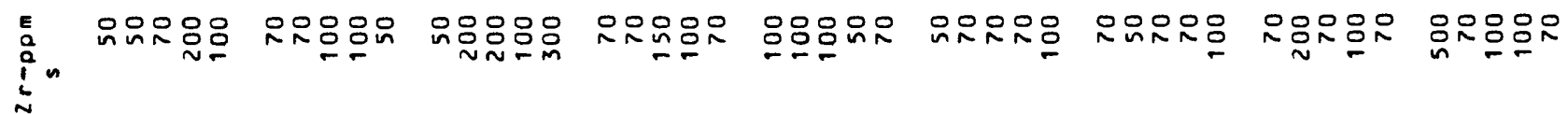

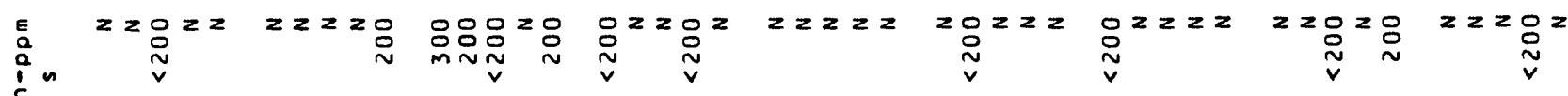

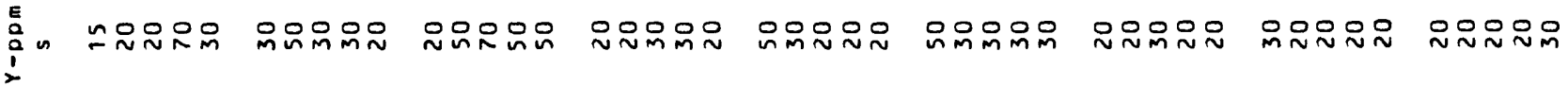
E.

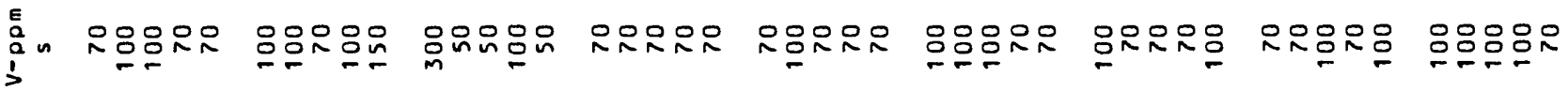

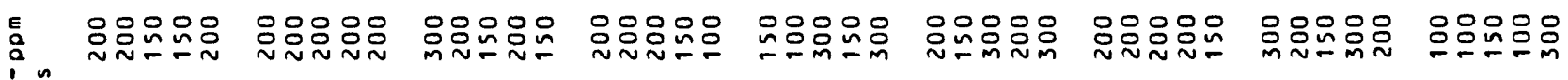
is

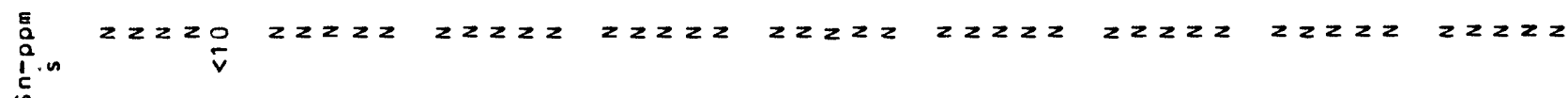

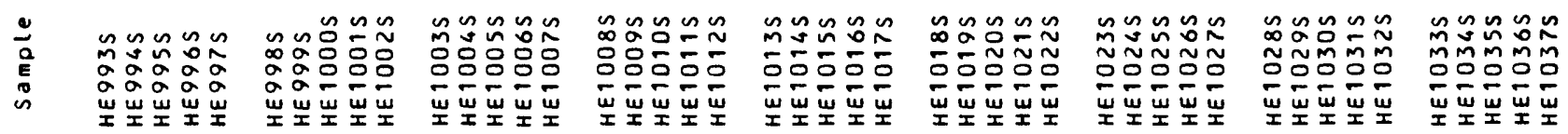




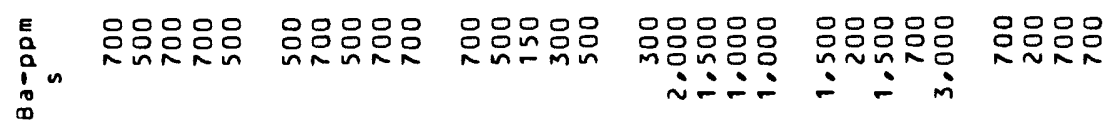

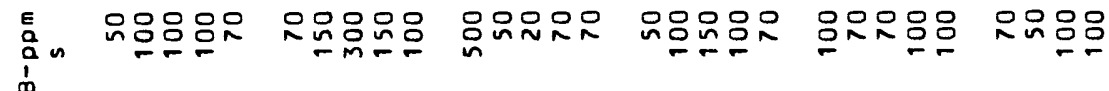

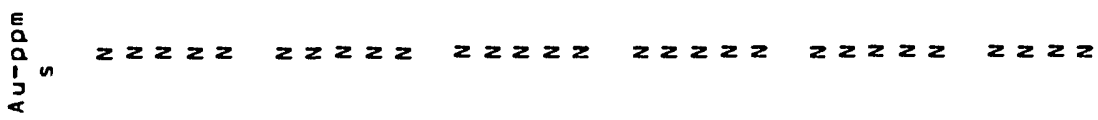

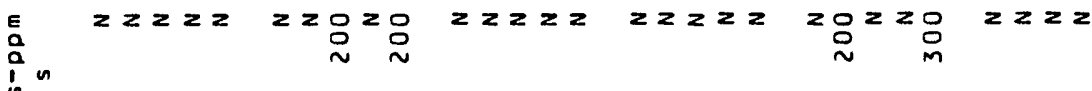

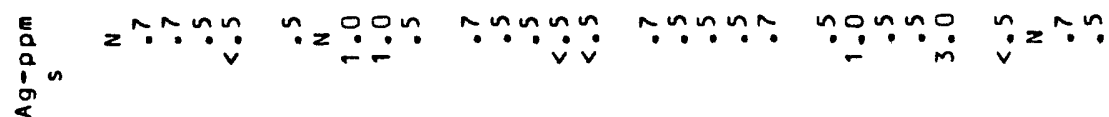

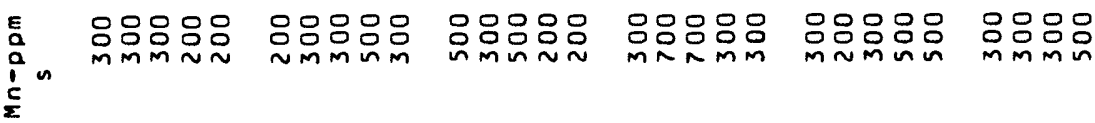

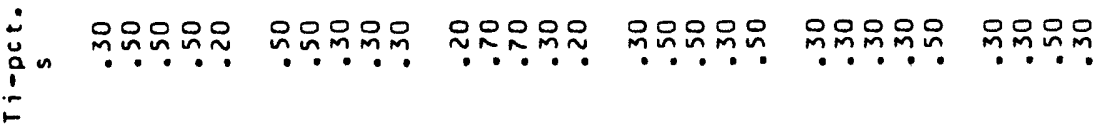

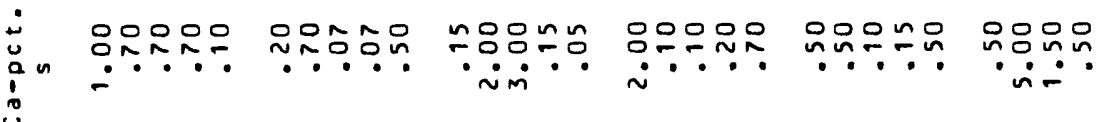

范

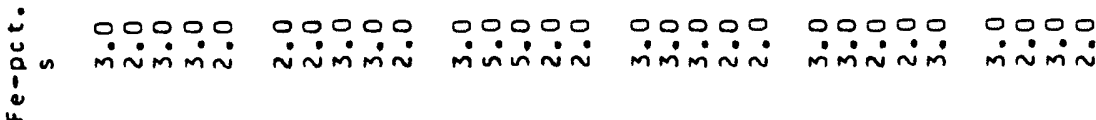

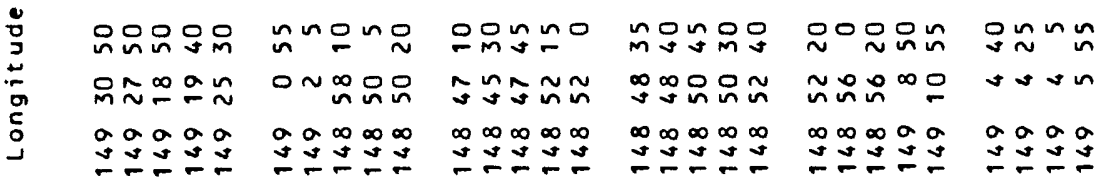

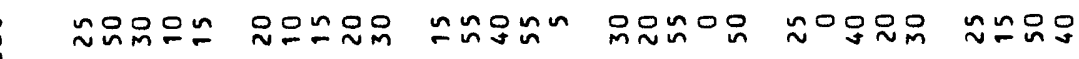
ongan - -moo oON-S DOONN

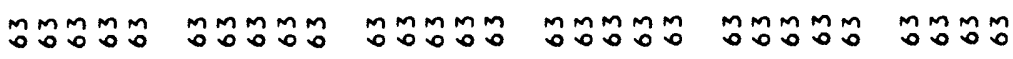

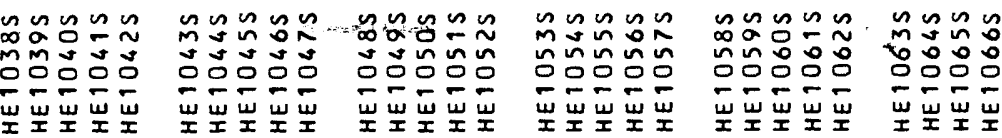




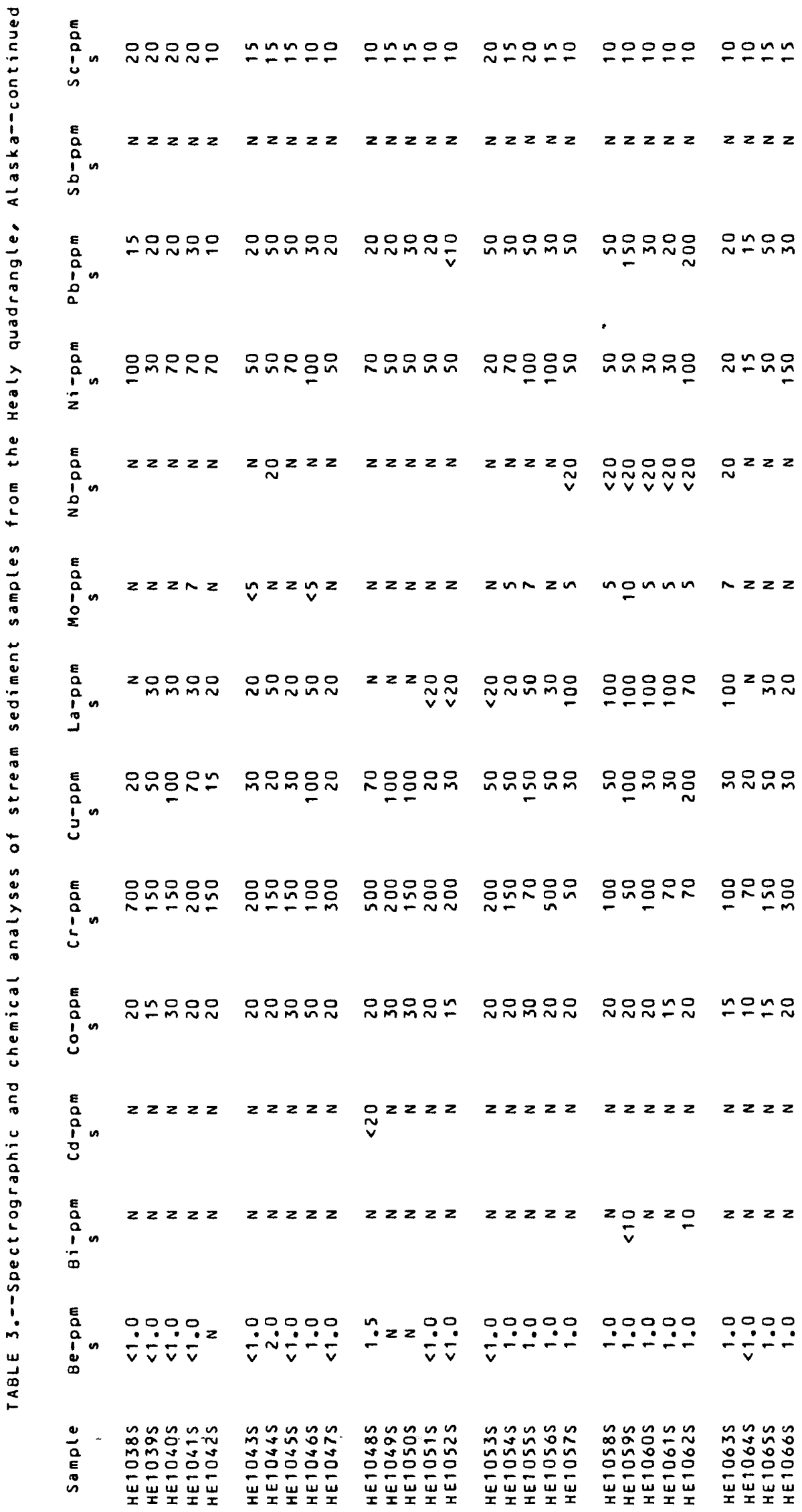




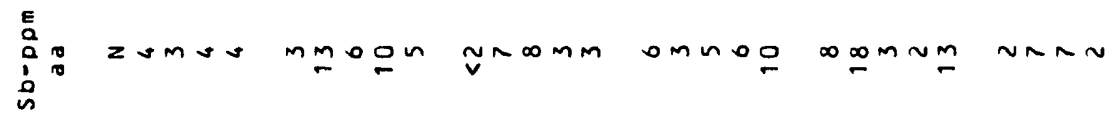

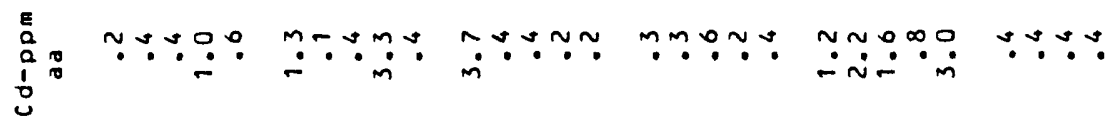

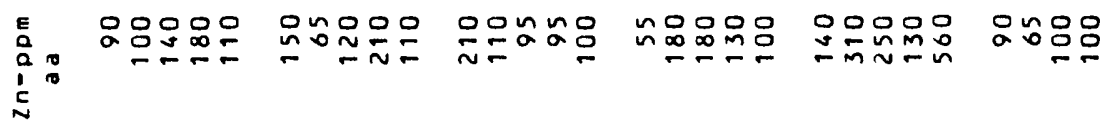

E⿱

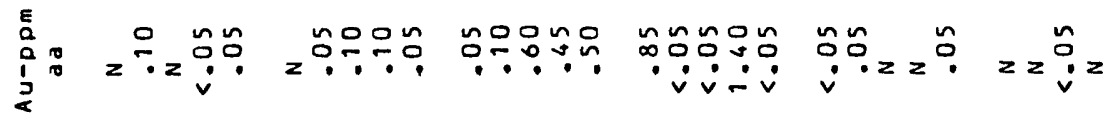

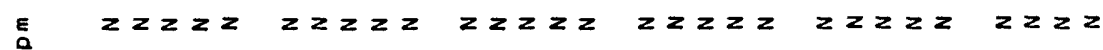

$i^{2}$

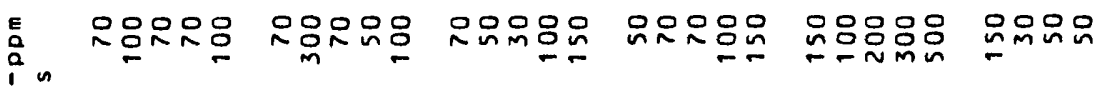

N

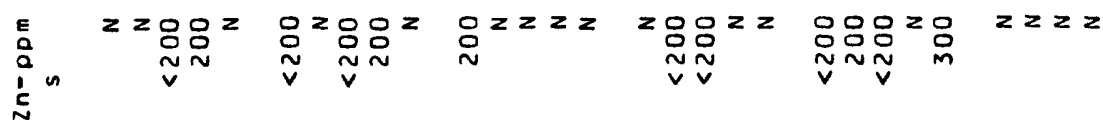

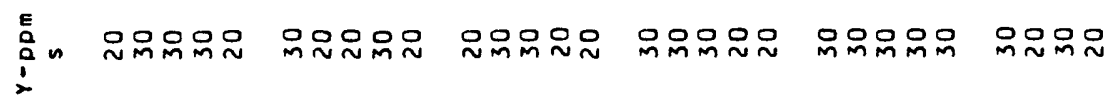

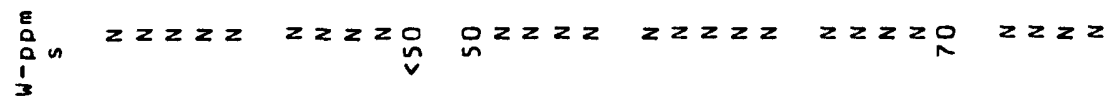

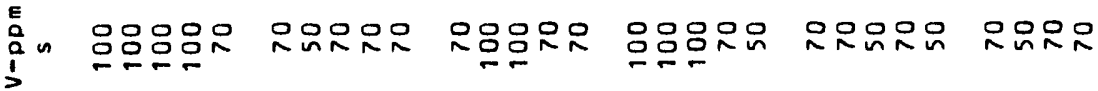

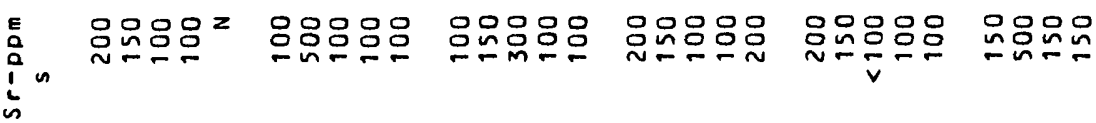

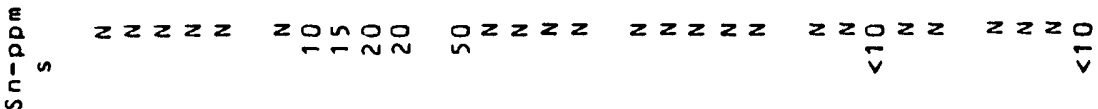

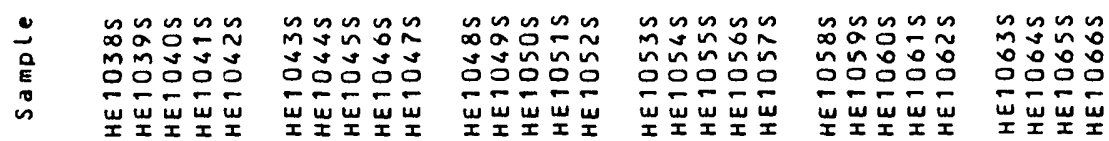




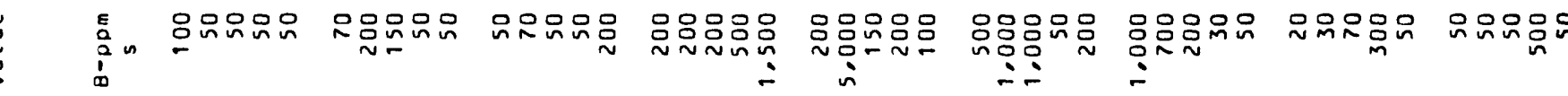

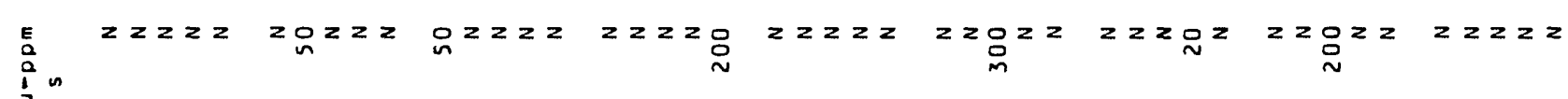

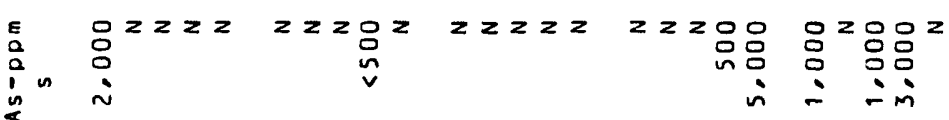

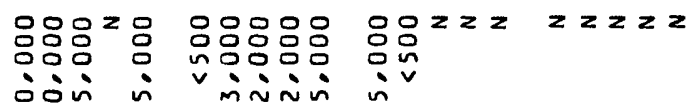

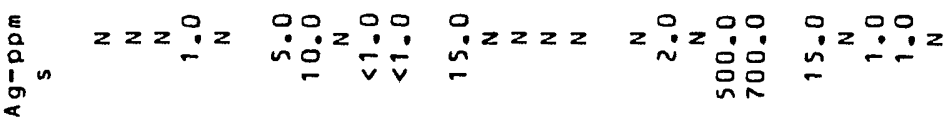

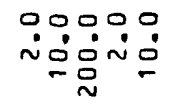

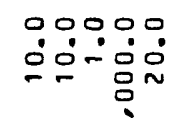

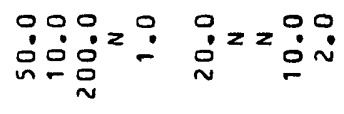

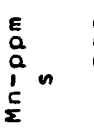

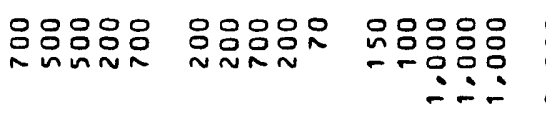

宫品品品

응응ㅇㅇㅇ

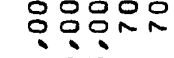

웅요:

음웃윳웅온

in

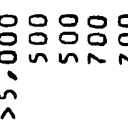

응응영응음

ํํㄴ

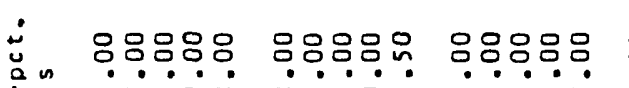

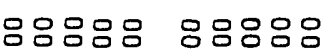

ํㅠ춧

$\dot{\wedge} \div \dot{\wedge} \div$

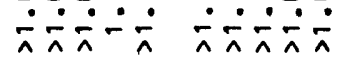

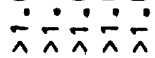

용요

응용음

옹ㅇㅇ음

त்춫

$\div \div \div \div$

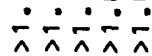

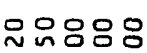

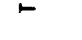

응응응웅

옹옹응 믐응음

옹응ㅇㅇㅇㅇ

옹음운

응용ㅇㅁ

음옹ㅇㅇㅇㅁㅜ

옹응응

inimin

- iñni

융ㅇㅁㅇㅇㅇㅇ

nimmin

inv - vinivivi

ทñก

mंñ்-

Nmiñ

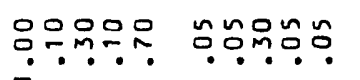

응ㅇㅁㅁㅁㅇㅛ

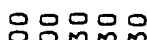

웅ㅇㅁ웅

웅ㅇㅇㅇ

00000

on

$\because \because \therefore \therefore$ ㅁ․

i்imin

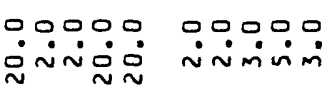

$\dot{1}$
$\stackrel{a}{a}$
$\vdots$
$\vdots$

mंimin

00000

0.0000

00000

00000

00000

$\because \therefore \dot{\pi}$

o

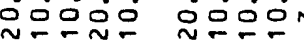

ำ

inño용

nuvin nín

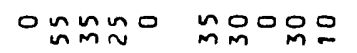

은유는

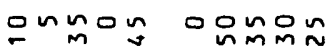

$\approx$ 品은

은ํำ

(n)

m $\sim^{\infty} \bar{m} \tilde{m}$

군은용

$\hat{\sim} \approx \infty \infty$

araa

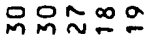

«nono

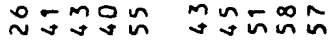

ㅁํํำ

$\pm \alpha a=0$

onamm

araa

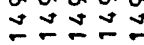

a a a a

요 n品品

テェニェす

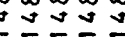

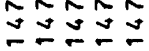

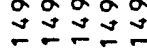

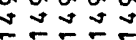

ンㅗㄹ

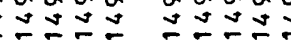

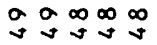

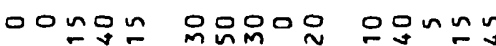

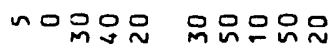

กำนกำ

nogon

으우요

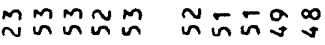

น NMmm

$=$ Ean

nบMm

งทño

NMNN

o ongo

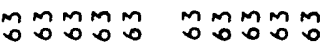

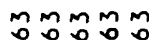

mmmmm mmmmm

mmmmm

mmmmm

mmmm

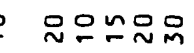

(1)

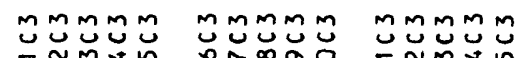

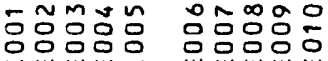

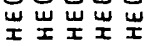

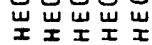

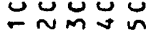

둤닸둤둔

MMMMm MMMMM

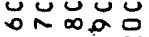

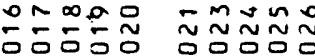

岌㞬岌岌

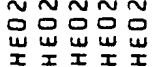

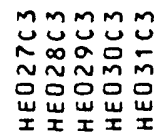

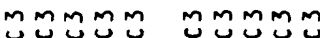

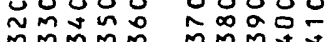

mómmo

써⼟씨

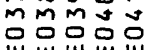

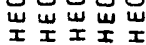

보ํํํํำ

minon

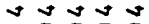

았은었은 


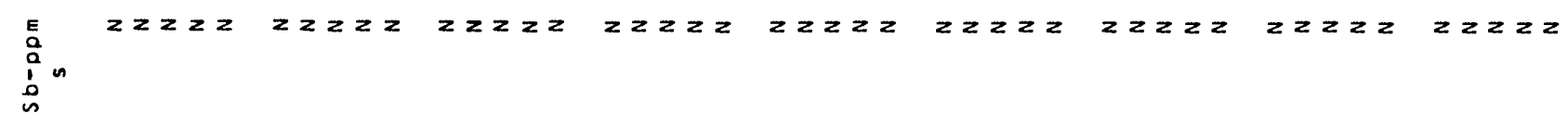

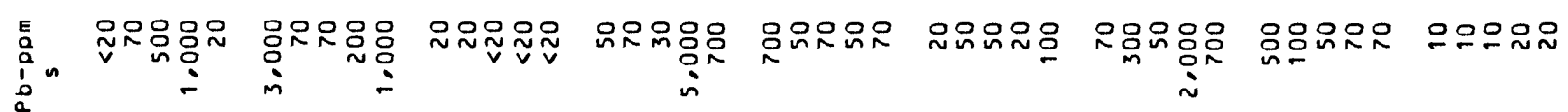

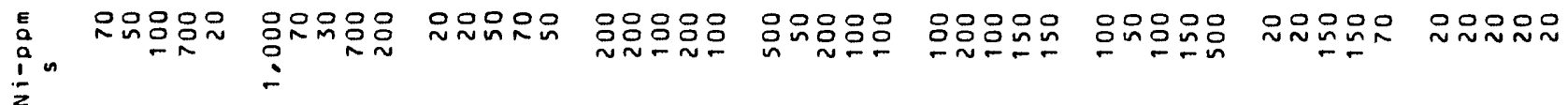

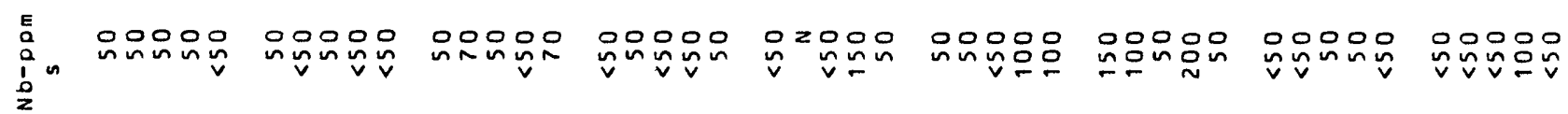

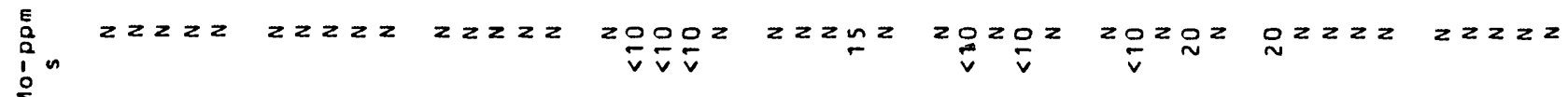

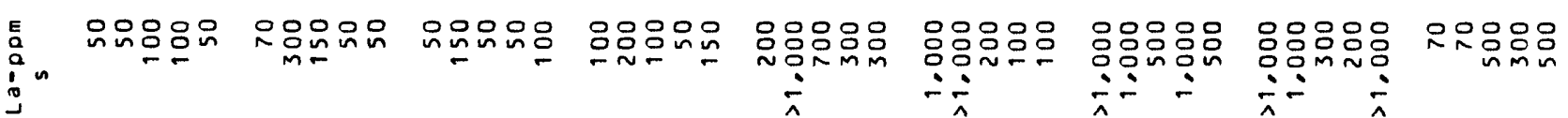

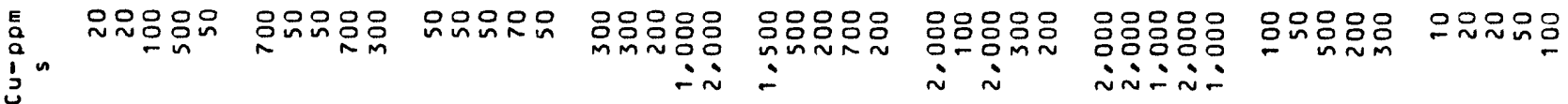

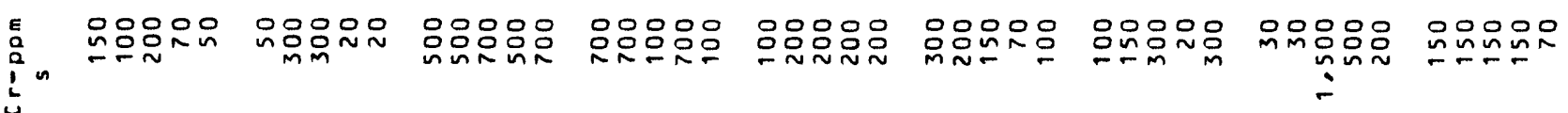

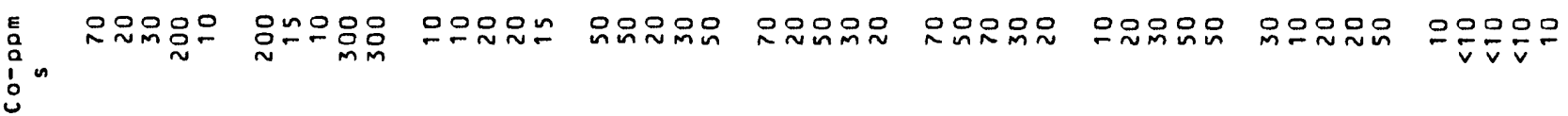

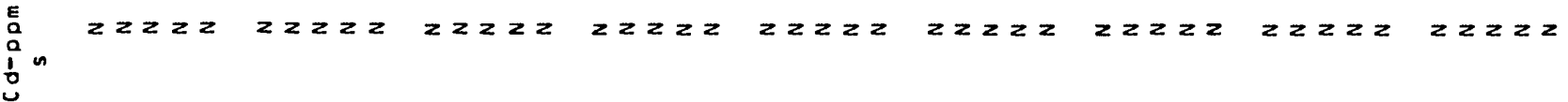

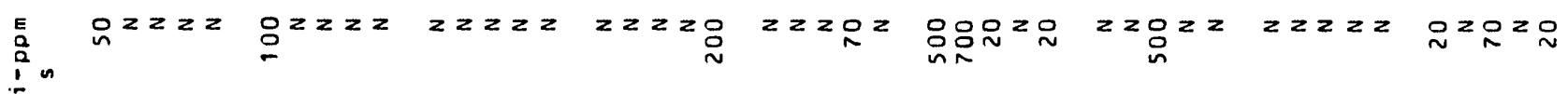

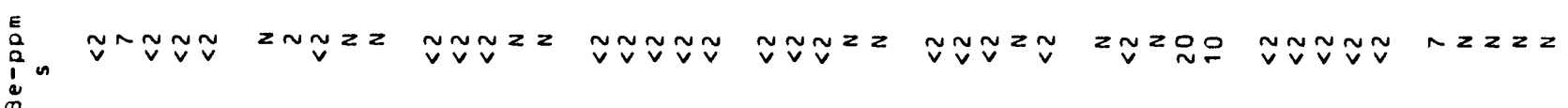

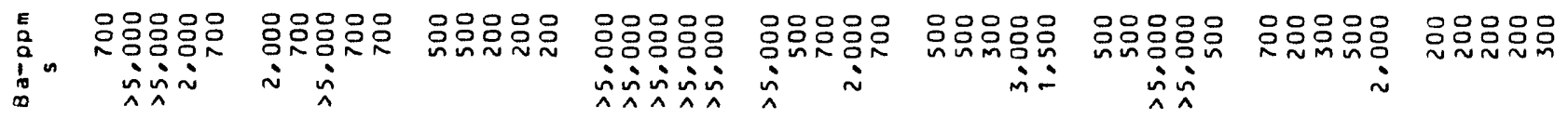

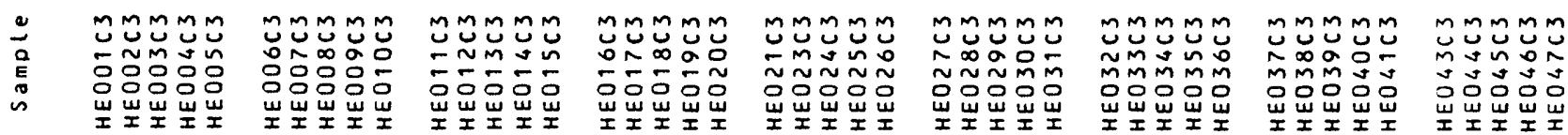




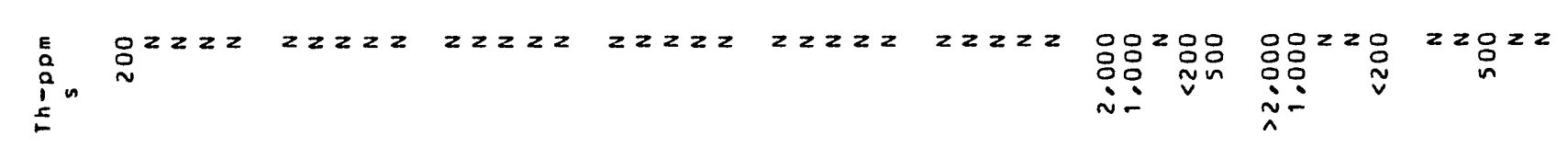

E

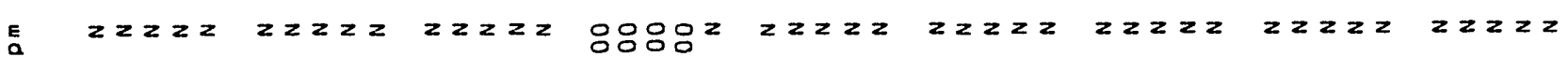
in

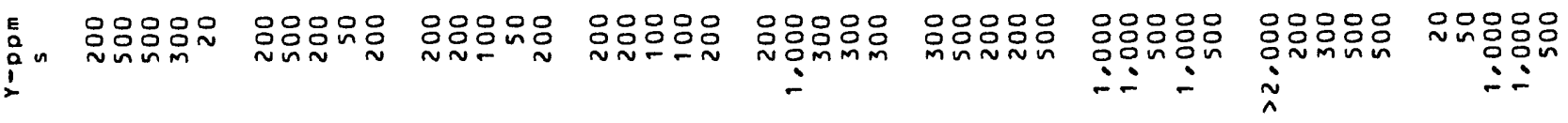

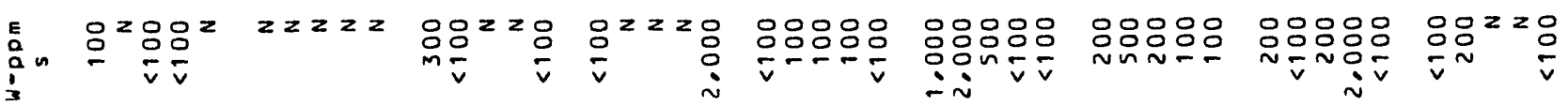

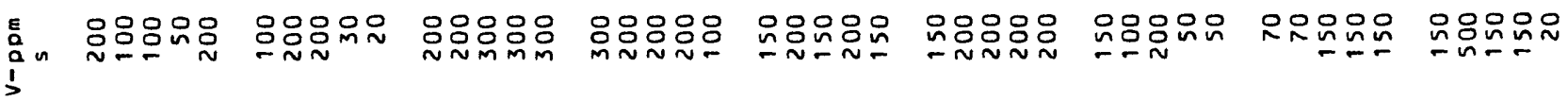

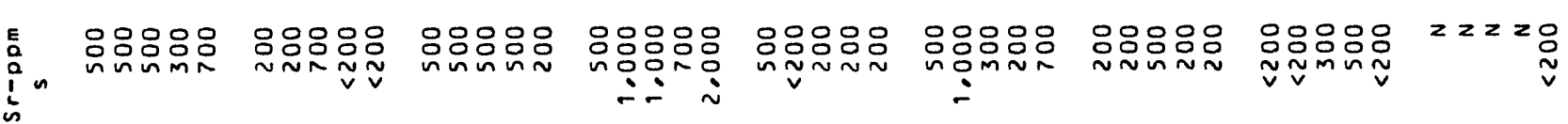

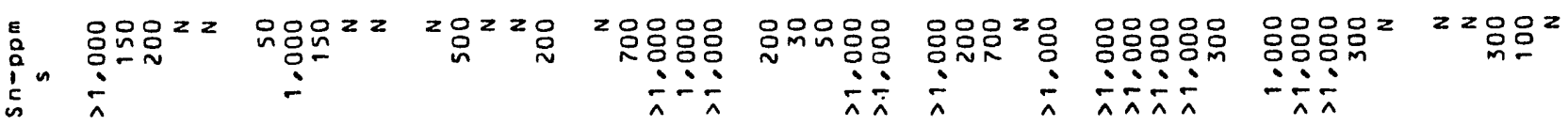

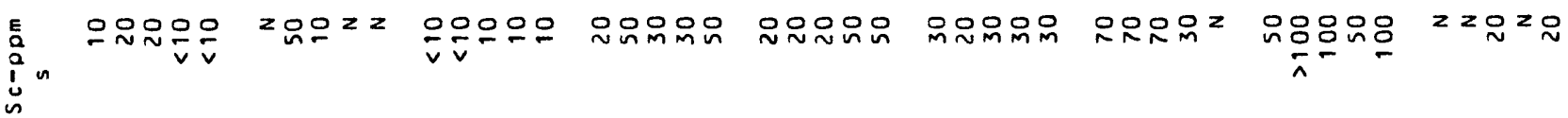

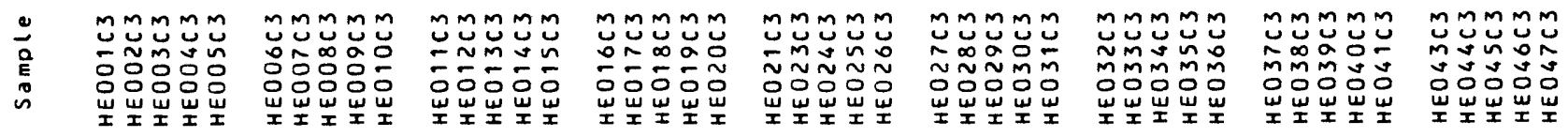




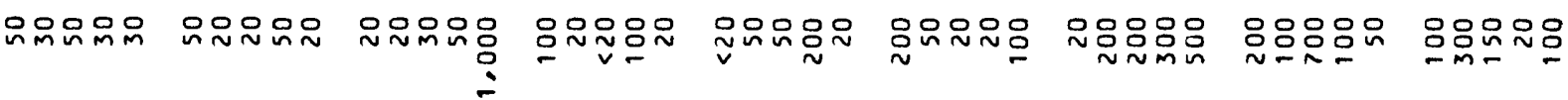

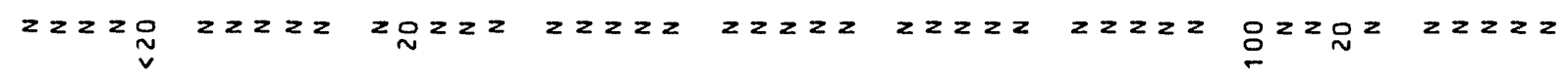

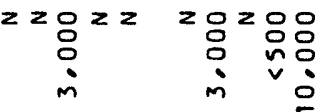

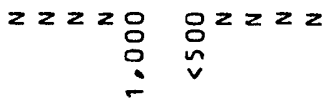

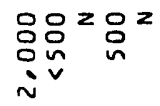

$^{2}<2=$
$\vdots$

$\begin{array}{rl}z & z \text { 응요 } \\ & \text { i ㄴ }\end{array}$

$z 0 z z z$
0
$n$

E $\frac{\text { ag }}{a}$ ing

$z=000$

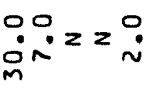

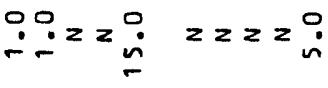

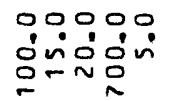

$\operatorname{ins}_{\text {in }} \operatorname{sz}^{2}$

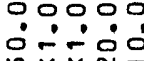

$\stackrel{0}{i} \stackrel{0}{\dot{0}} \dot{\sim}^{2}$

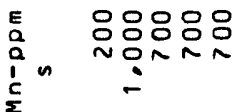

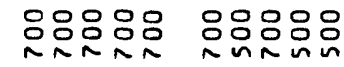

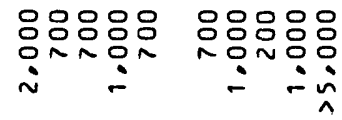

응응응ㅇㅇㅇㅇㅛ

$\because \because \div$

응응웅응음 응음음음옹

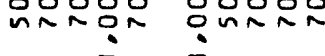

옹응ㅇㅇㅇㅇㅇㅇㅇㅡ

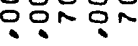

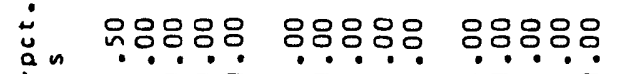

옹응응응응

응응응응응

옹응옹ㅇㅇㅇㅇㅡ.

응옹응ㅇㅁㅇㅇㅇ

응응옹옹응

응웅옹응

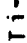

뚜춧

$\pi \div \pi \bar{\Lambda}$

$\pi \pi \pi \pi$

$\because \because \div \div$

추추수

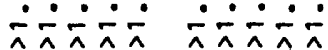

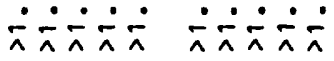

范n

응응응응

응응옹음

응응웅응영

은용용응

응은응ㅇㅇ

응응응옹ㅇㅇ

옹응ㅇㅇㅇㅇㅇ

8

응용용

نंvimin

ที่ن்

응응ㅇㅇㅇ<smiles>CCC</smiles>

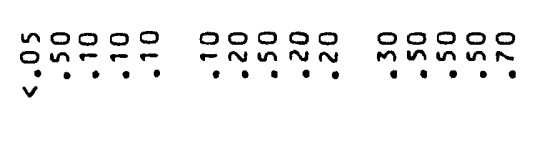

운은은은 은은은

응웅오운

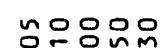

$\therefore$

vivinin

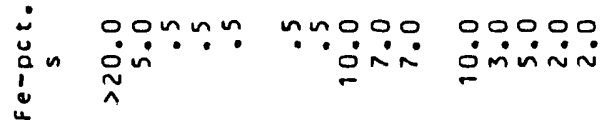

00000

00000

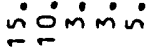

- 두ำin

0.000

등ำ

¿̊ำ:ำ

용ㅇㅇㅇ

0.000

-

inim-

을느o nongog ษทฐกำ

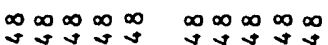

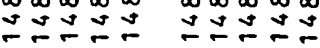

옹유는 $\sim \sim 00 \infty 0$

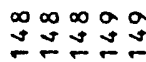

뜽ํำ 웅ํㅇㅇㅛ

OONR DOON

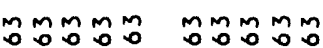

nog용

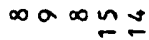

móño

능요

$E=\infty \sim n$

gogono

UNO든

mơ

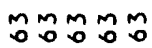

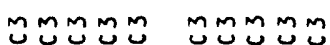

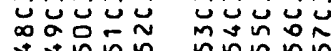

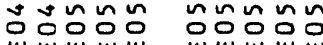

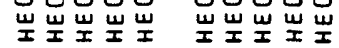

M포픔

ํํํํํํำ

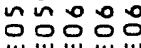

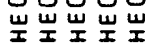

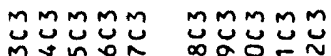

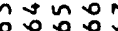

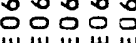

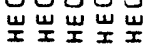

m

웄었웅

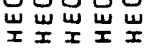

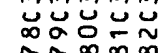

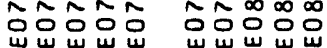

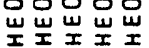

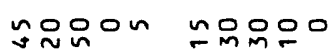
운요슨

$\infty \infty \infty \infty \infty$

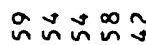

$\infty \infty \infty \infty \infty$

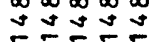

n⿻ำ $n$ ก

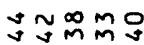

$\infty \infty \infty \infty \infty$ 


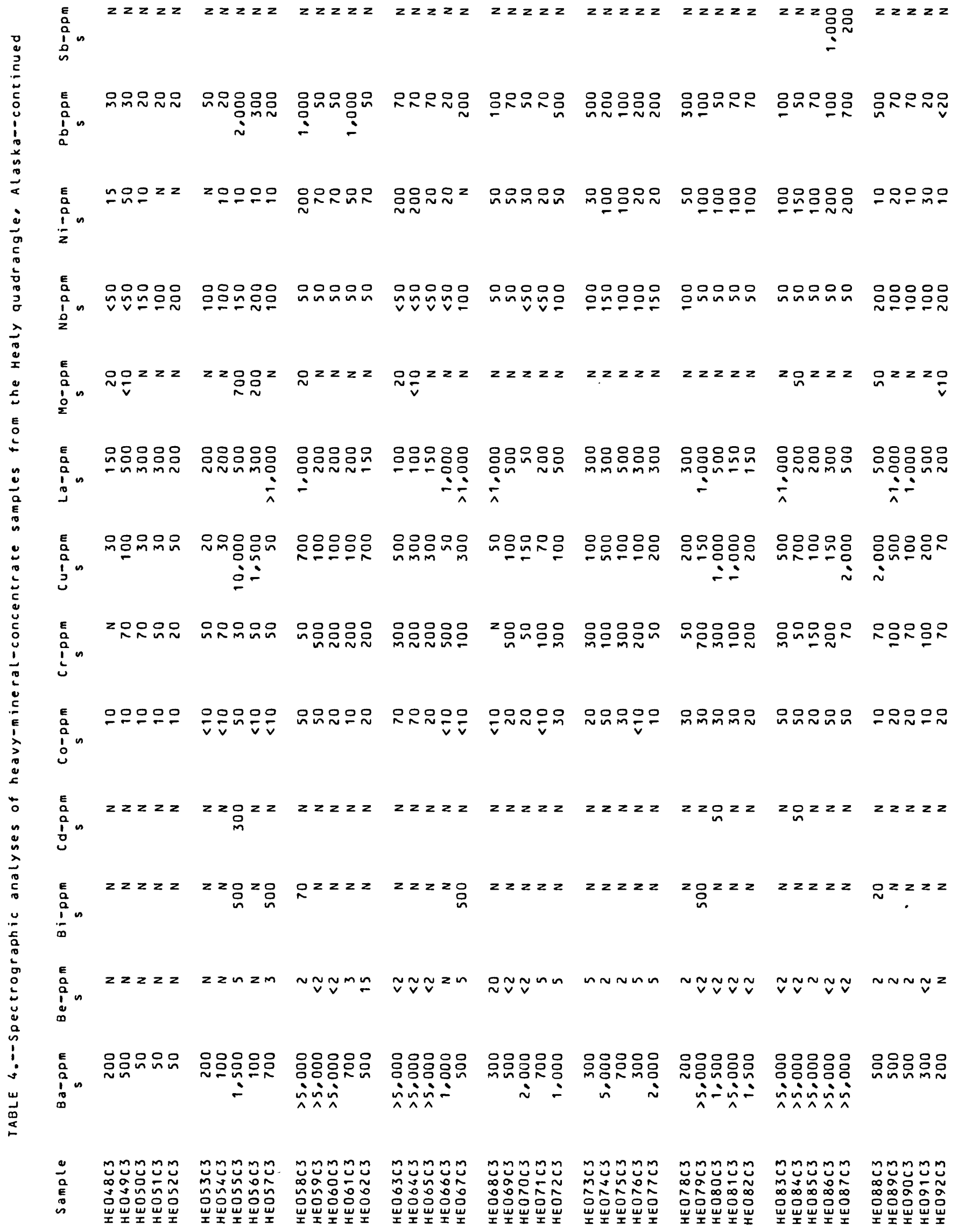




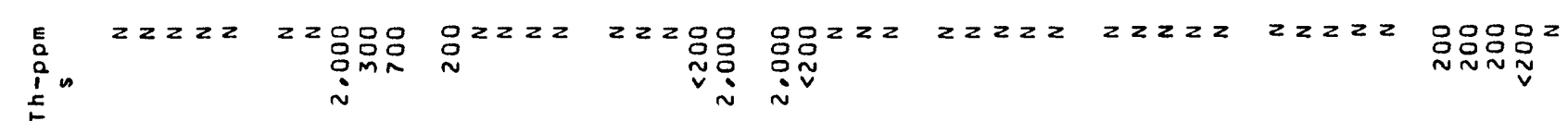

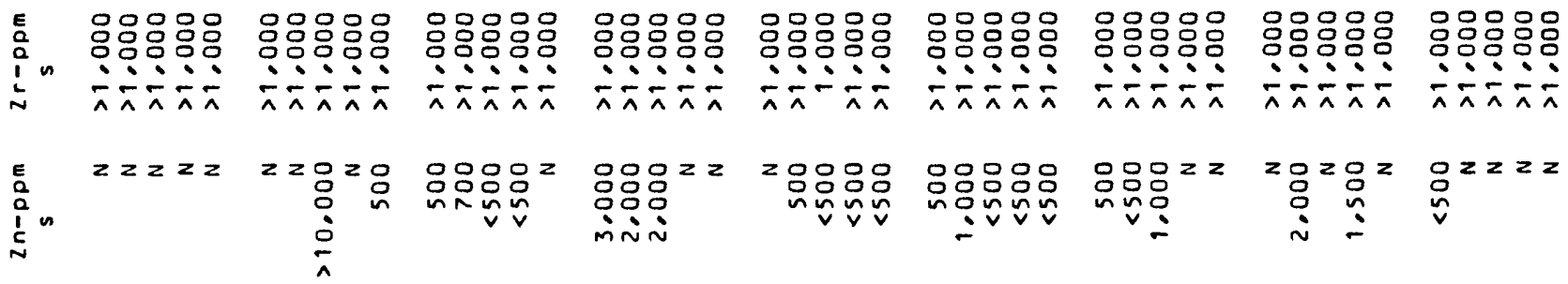

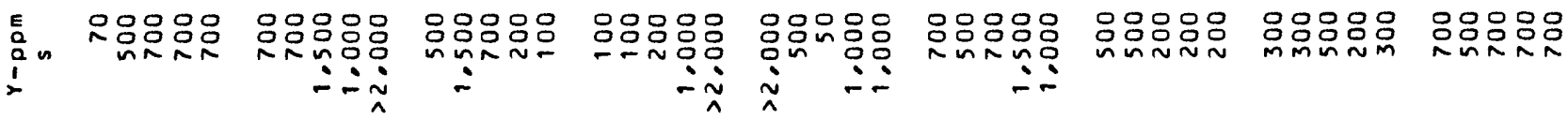

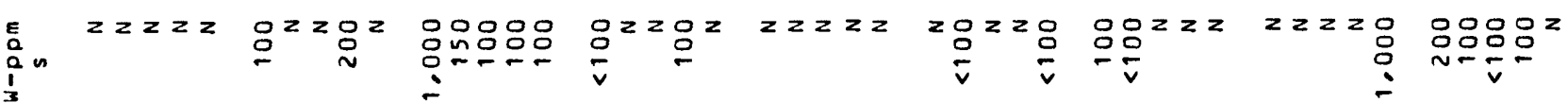

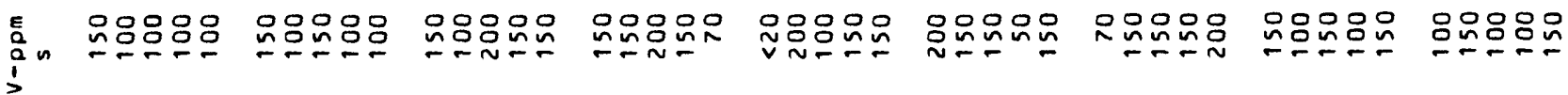

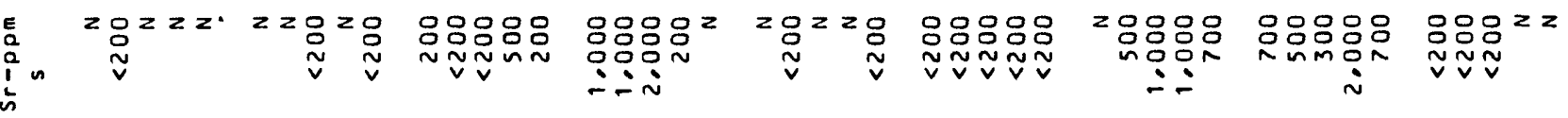

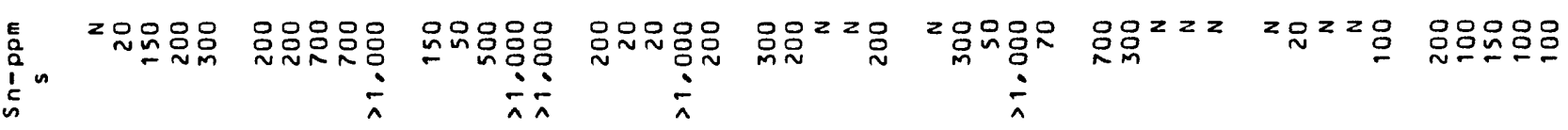

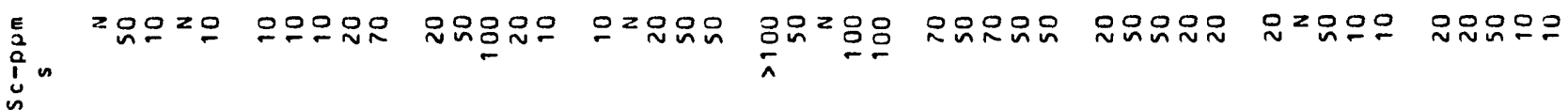

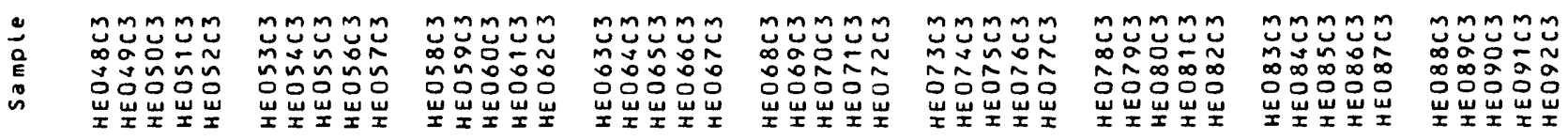




\begin{tabular}{|c|c|c|c|c|c|c|c|c|c|}
\hline $\begin{array}{l}\text { E } \\
a_{n} \\
1 \\
\text { ma }\end{array}$ & 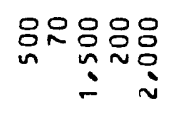 & 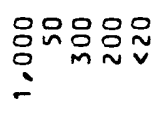 & 음임옴ㅇㅁㅁㅇㅛ & 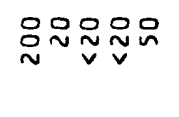 & 总品品品品 & 응음응음므 & 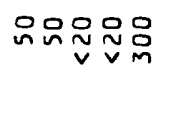 & 옴ㅇㅁㅇㅇㅁㅇ & 옥옴ㅇㅁㅇㅁㅁ \\
\hline $\begin{array}{ll}\text { É } \\
0 \\
0\end{array}$ & $z z z z z$ & $z z z z z$ & $z z z z z$ & $z z z z z$ & $z z \geq g_{n}^{z}$ & $z z: z z$ & $z z z z z$ & $z z z z z$ & $z z z z$ g \\
\hline $\begin{array}{l}\text { E } \\
a \\
a \\
i_{n} n \\
\alpha\end{array}$ & $z z z z z$ & 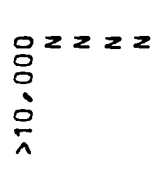 & $\begin{array}{c}z z=g \\
\vdots \\
\vdots\end{array}$ & $z 2 z z z$ & $\begin{array}{l}z: z z= \\
\dot{m}\end{array}$ & $\begin{array}{l}0^{2} g^{2} \circ \\
\vdots: \\
:\end{array}$ & 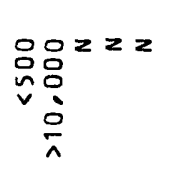 & $z z z z z$ & $z g_{n} z=g$ \\
\hline 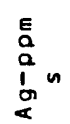 & $z z 2 z z$ & $\dot{g}_{n} z z z z$ & $\because z z z 2$ & $z z z \ddot{0}$ & 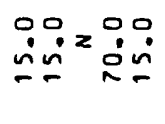 & 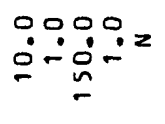 & $\because \ddot{0} z=2$ & $z z z z z$ & $z z z z \stackrel{\circ}{\circ}$ \\
\hline 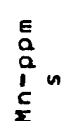 & 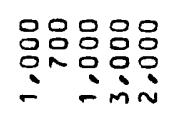 & 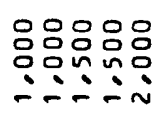 & 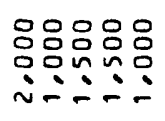 & 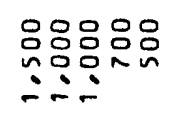 & 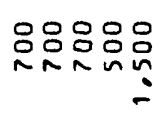 & 응읏음욤요 & 음웅ㅇㅁㅁㅇㅁㅁ & 웃음음ㅇㅁㅁ욤 & 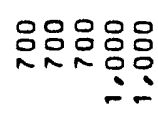 \\
\hline $\begin{array}{l}\dot{0} \\
u \\
a \\
\vdots \\
\vdots \\
E\end{array}$ & 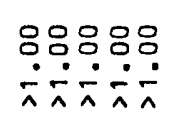 & 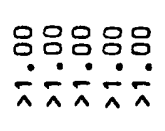 & 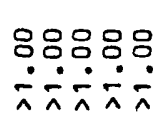 & 응응음 & 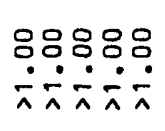 & 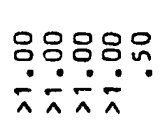 & 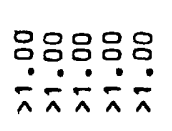 & 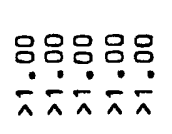 & 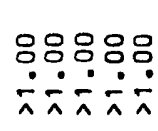 \\
\hline $\begin{array}{l}\dot{b} \\
\vdots \\
a \\
0\end{array}$ & 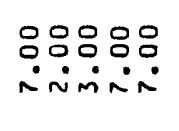 & 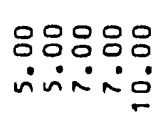 & 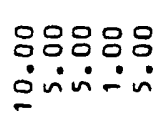 & 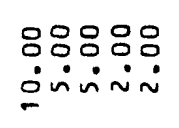 & 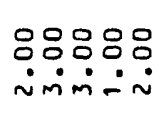 & $\begin{array}{l}\text { 용ㅇㅇㅇ } \\
\text { imimiñ. }\end{array}$ & 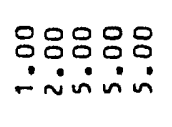 & 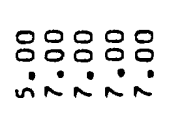 & 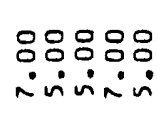 \\
\hline $\begin{array}{l}\dot{\vdots} \\
\vdots \\
\vdots \\
\vdots \\
\vdots\end{array}$ & 운옴요문 & 욤욤ㅇㅁㅁ & 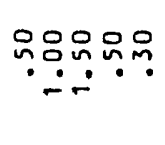 & 욤욤ํ. & 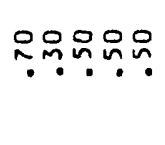 & 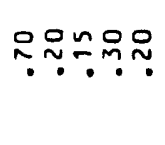 & 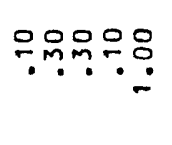 & 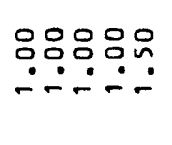 & 只品品品 \\
\hline$\dot{a}_{a}$ & 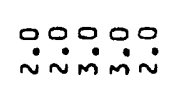 & 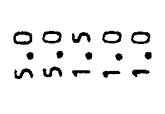 & 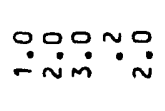 & 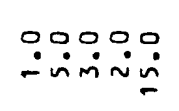 & 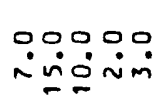 & o0:0: & :00:뭄 & 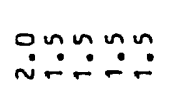 & 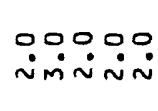 \\
\hline 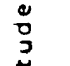 & o品品品 & 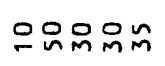 & 우음ำㅁำ & $\approx D \sim \mathcal{\sim} \approx \approx$ & oonูnด & 乞웅요 & non mon & 프믐ㅇㅇㅁㅇ & 음으믄 \\
\hline$\sigma$ & Sợnminn & $\min _{m}^{\infty} \tilde{N} \tilde{N}$ & $\stackrel{m}{\sim} \sim \infty \sim$ & N $\sim$ 品品: & 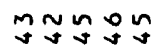 & 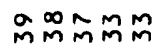 & 옴ำ $\sim \underset{\sim}{\sim} \approx$ & テニ゚゚ュ & $ニ ゚ ぇ \bar{n}$ \\
\hline$\stackrel{5}{-2}$ & 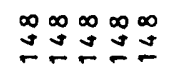 & 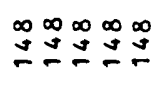 & 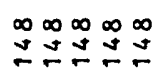 & 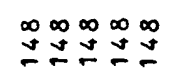 & 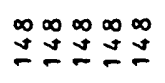 & 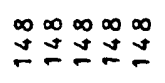 & 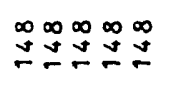 & 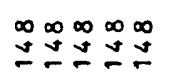 & 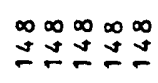 \\
\hline$\stackrel{0}{7}$ & 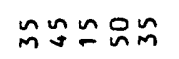 & 임음음 & o욤ㅁㅇㅢ & 음ㅇㅇㅁ $\approx \sim$ & $\tilde{m} n g \approx \tilde{v}$ & ponnn & no의 $n \simeq$ & nㅁㅁㅇㅁㅁ & ngon \\
\hline$\frac{5}{\pi}$ & $n \circlearrowleft m \sim \sim$ & $00-\sim N$ & N NO & $+\infty 000$ & ๓aニ゚゚ & $\simeq \bumpeq \simeq \stackrel{\infty}{\sim}$ & $\stackrel{2}{\simeq} \simeq \stackrel{0}{\sim}$ & $\approx \simeq \stackrel{\infty}{\sim} \cong$ & $\tilde{\sim} \sim \sim \sim$ \\
\hline$\underbrace{0}_{-1}$ & 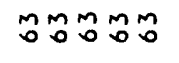 & 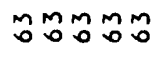 & ตีคตำต & 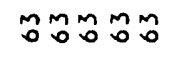 & 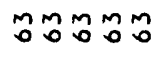 & 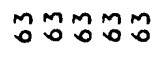 & 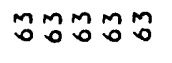 & 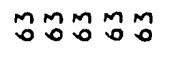 & MMㅗำ \\
\hline $\begin{array}{l}\stackrel{0}{a} \\
\stackrel{a}{E} \\
0 \\
\infty\end{array}$ & 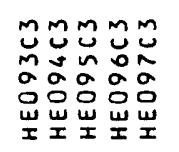 & 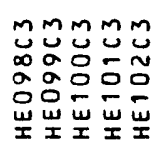 & 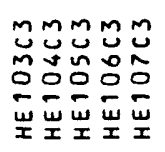 & 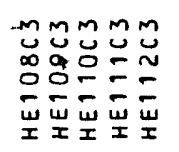 & 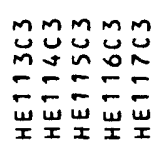 & 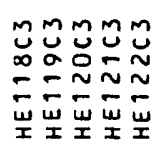 & 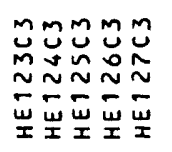 & 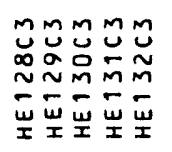 & 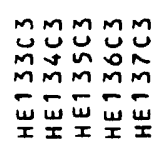 \\
\hline
\end{tabular}




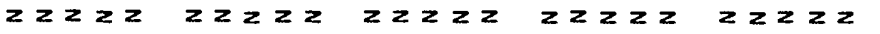

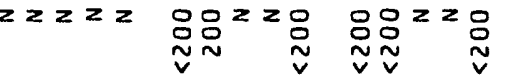

욤 $2 \geq 2 \geq$

$E$
$\vdots$
$\vdots$
$\vdots$
$a$

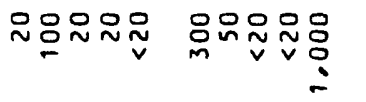

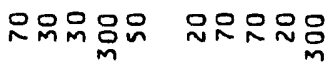

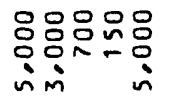

은융ㅇㅁㅇㅁㅇㅛ

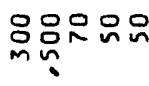

웃유융ㅇ 음음은

$\sum^{E}$

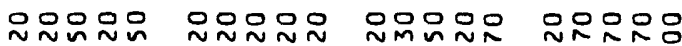

옹음응응웅

은응요옹

온은웅ㅇㅇ

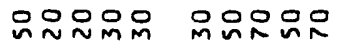

E

0000000000000000000000000

ำ $\sim$ 은

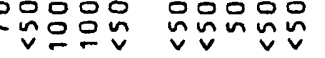

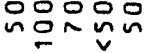

n느응ㅇㅁㅇ

o이요

잉ㅇㅇㅇㅇㅇ

ingingo

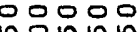

$\frac{E}{l_{0}} \frac{0}{v} z z z \frac{0}{v} \quad 0 z z z$

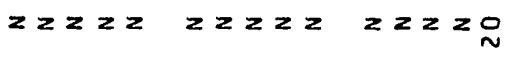

으은

$0 z z z z z z z z z z z z$

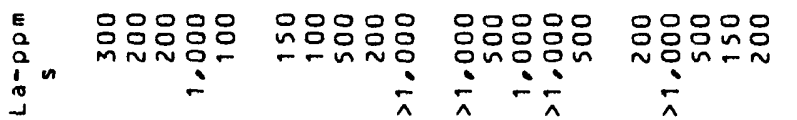

옹ㅇㅇㅇㅇㅇㅇ

象兄

은응유요

กับำ

응용ㅇㅁ욤

옹으웅응

응ㅇㅇㅇㅇㅇㅇㅇㅇ : $n N m$

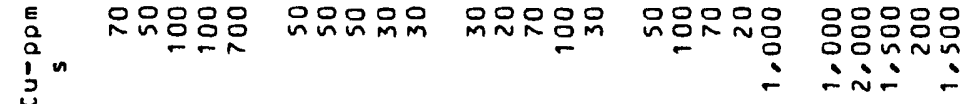

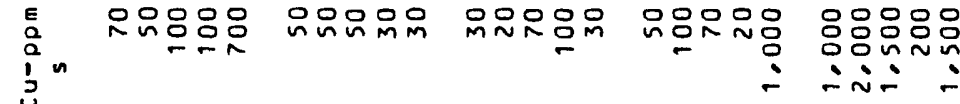

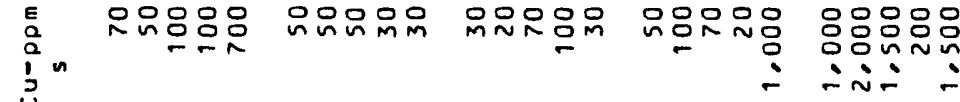

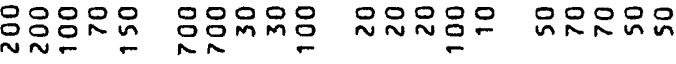

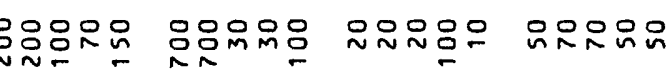

$\sum_{\substack{a \\ 0}}^{e}$

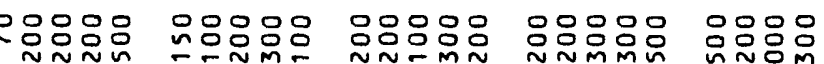

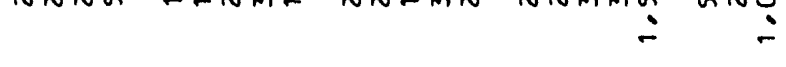

$E$
0
$\vdots$
$\vdots$
0

유잉 00000 000응 00000 00000

$\sim \sim \sim-$

$\simeq \div+\div$

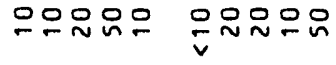

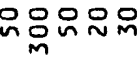

온은음

은므응으우

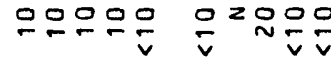

$E$
0
0
$\vdots$
0

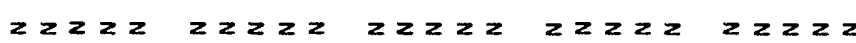

$z \geq z \geq z$

$z z z z 2 z z z 2 \quad z z z 2$

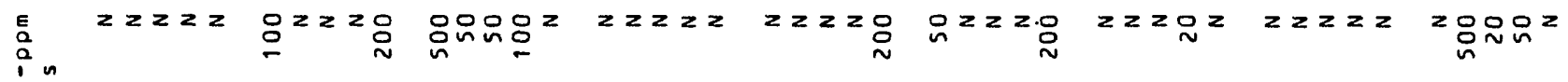

$\sum_{\substack{E \\ 0}}^{E}$

$z \tilde{v} z z \quad 2 \sim 2 z z$

$z<z<2$

$z=2 z \tilde{v} \sim \tilde{v} z z$

$n-z \geq 0$

$\tilde{v} \sim z \geq \sim$

$z \geq 2 z 2$

$Z M N N N$

$\sum_{\substack{E \\ 0 \\ 0 \\ 0}}^{0}$

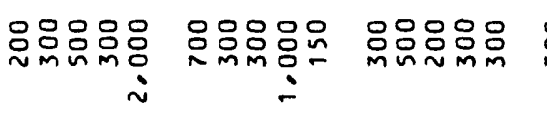

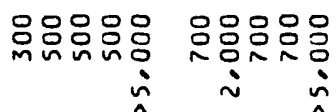

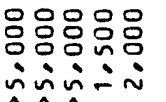

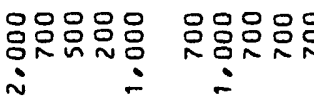

음암응용웅

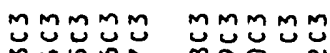

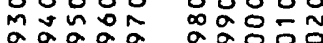

본본

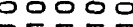

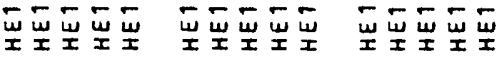

og음ำ

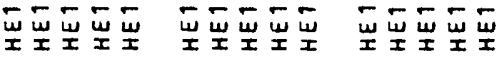

mummm

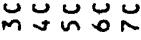

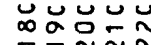

MMMMM

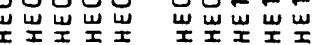

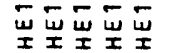

N N NMMM

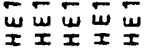

$\bar{w} \bar{w} \bar{w}=$

MÜmMm

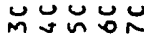

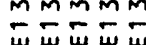




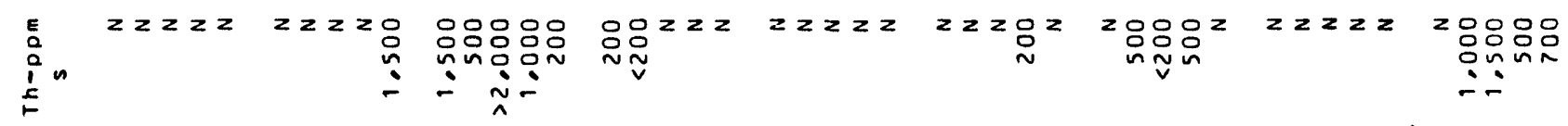

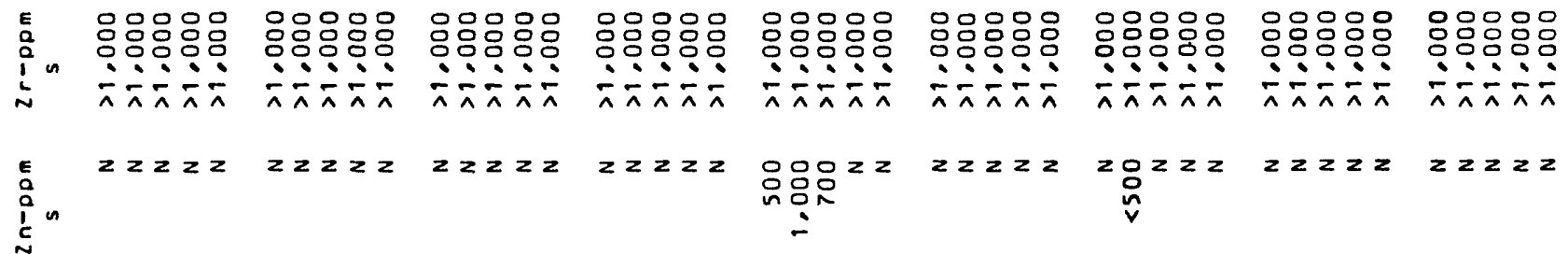

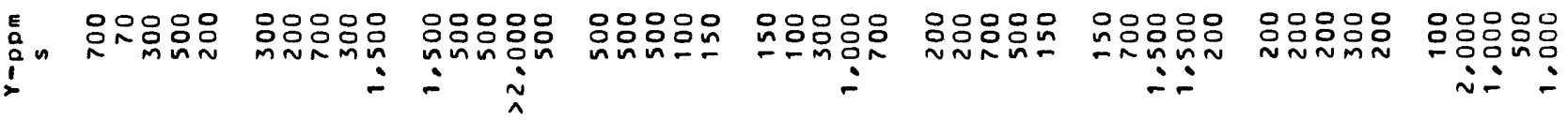

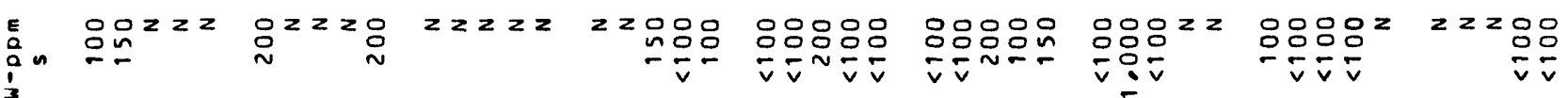

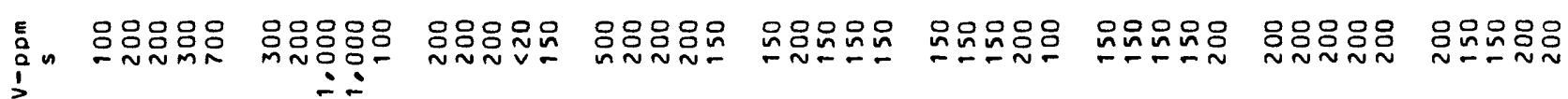

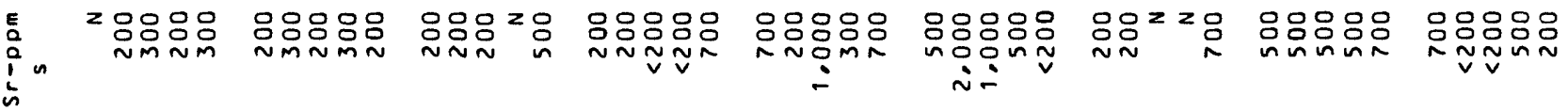

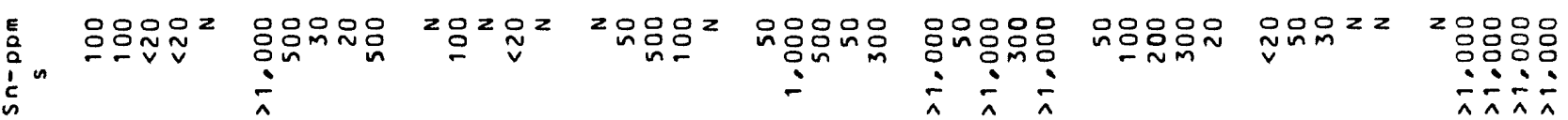

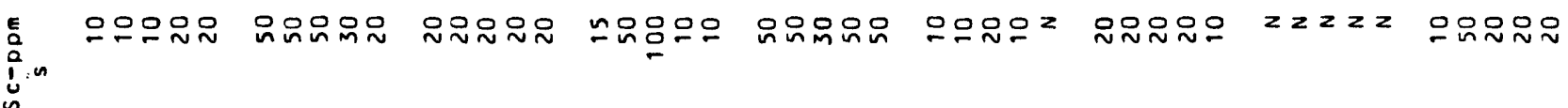

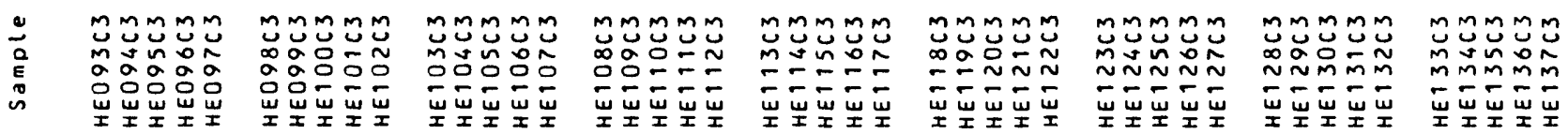




\begin{tabular}{|c|c|c|c|c|c|c|c|c|c|}
\hline $\begin{array}{l}\text { E } \\
\text { an n } \\
\vdots \\
0\end{array}$ & 음음음용요 & 음옹용ㅇㅁ음 & $\begin{array}{l}\text { 응용ㅇㅇㅇㅁ } \\
\text { i }\end{array}$ & 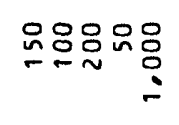 & $\begin{array}{l}\text { 음웅ㅇㅇㅇ } \\
: \quad \text { : }\end{array}$ & 응욤윰ㅇㅁ & 무웜워 & 원윰ㅇㅁㅇ & 웅ㅇㅇㅇㅇㅇㅇㅇ \\
\hline $\begin{array}{l}\text { E } \\
\vdots \\
\vdots \\
\vdots \\
a\end{array}$ & $z z z z z$ & $z z z z z$ & $z z z z z$ & $z z z z z$ & $z z z z z$ & $z z z z z$ & $z z z z z$ & $z z z z z$ & $z z z z z$ \\
\hline $\begin{array}{l}E \\
a \\
a \\
\vdots \\
\vdots \\
a\end{array}$ & $z z 2 z 2$ & 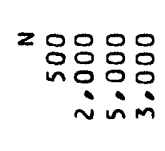 & $\begin{array}{c}z 20 z 2 \\
\vdots \\
\vdots\end{array}$ & $\begin{array}{r}z z z=0 \\
\vdots \\
\vdots \\
\vdots\end{array}$ & $\begin{array}{c}O^{2}=O^{2} \\
\vdots \\
\vdots\end{array}$ & $z z z z z$ & $z z z z z$ & $z 2 z 2 z$ & ${ }_{i n} 2 z 2 z$ \\
\hline $\begin{array}{l}\text { E } \\
\text { a } \\
\operatorname{lin}^{\circ} \\
8\end{array}$ & $z \stackrel{\square}{\because} \because \stackrel{0}{\circ}$ & $z z_{n}^{0} z z$ & $z z z z z$ & $z z z z z$ & $\dot{n}=2 z \stackrel{0}{n}=$ & $z z z z z$ & $z z z z z$ & $z z z z \stackrel{0}{0}$ & $\dot{i}=\frac{0}{\dot{v}}$ \\
\hline $\begin{array}{l}\text { E } \\
\text { a } \\
i=n \\
\text { in }\end{array}$ & 응음음욤음 & 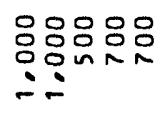 & 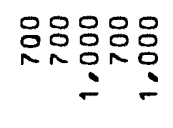 & 음읏읏ㅇㅇㅁ욧 & 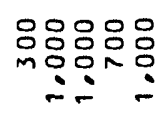 & 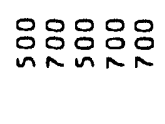 & 음옴욤음 & 옴옴ㅇㅁㅁ욤 & 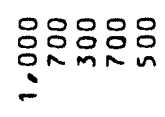 \\
\hline $\begin{array}{l}\dot{a} \\
\dot{a} n \\
i \\
\underline{z}\end{array}$ & 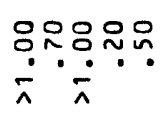 & 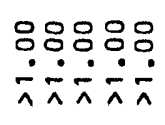 & 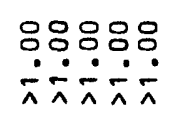 & 웅응ㅇㅇㅇㅠ & 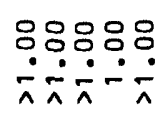 & 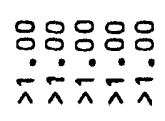 & 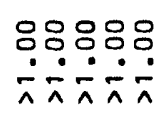 & 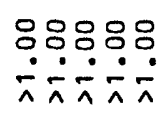 & 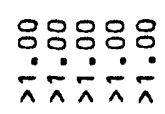 \\
\hline $\begin{array}{l}\dot{\vdots} \\
\vdots \\
\vdots \\
\vdots\end{array}$ & 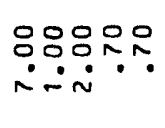 & 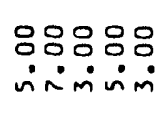 & 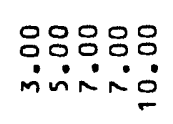 & $\begin{array}{l}\text { 응ㅇㅇㅇㅇ } \\
\text { ㅁํㅇㅇㅁ }\end{array}$ & 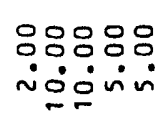 & 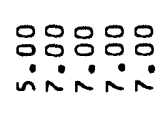 & $\begin{array}{l}\text { 영응ㅇㅇㅁ } \\
\text { íㅇㅇㅇㅇ }\end{array}$ & 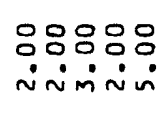 & 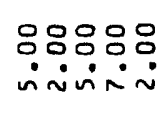 \\
\hline $\begin{array}{l}\dot{\vdots} \\
a_{0} \\
\vdots \\
0\end{array}$ & ํํํ윰ํํํํ. & 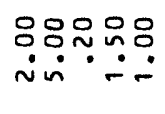 & 웁욤요뭄 & 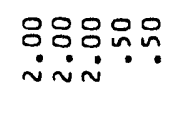 & 옵ํํํ유 & 옴움ㅇㅇㅁ음 & 운윰우 & 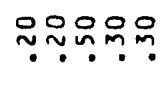 & 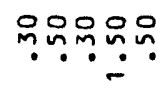 \\
\hline $\begin{array}{l}\dot{\vdots} \\
\dot{a} \\
\vdots \\
\vdots \\
u\end{array}$ & 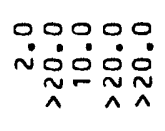 & mĩi & OO:O०O & 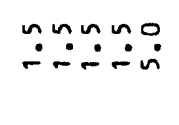 & 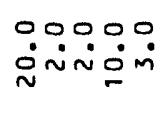 & & 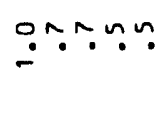 & $\because \simeq \because n$ & 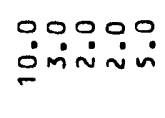 \\
\hline$\frac{\vdots}{3}$ & 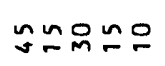 & Oำกñ & ○ 品 N & 웅묭ㅁㅇㅇㅁ & 웅용ㅇㅇㅇ & 윰ㅇㅁㅇㅇ & 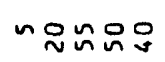 & 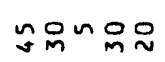 & og ging \\
\hline a & 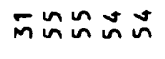 & $\because \cong \cong \simeq \approx$ & 웅ㅁ & $\approx D a-\sim$ & N $O M$ & $\approx a \approx m \sim$ & $\approx \infty M m n$ & $\because \approx \Sigma \stackrel{\sim}{\sim}$ & $--a r a$ \\
\hline$\stackrel{0}{د}$ & 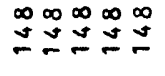 & 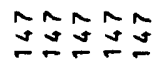 & 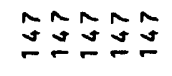 & 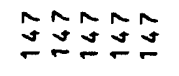 & 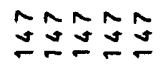 & 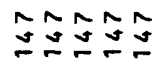 & 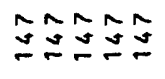 & ミミミミ゙す & 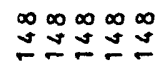 \\
\hline ซั & $\operatorname{nog} \ln ^{\prime} n n$ & 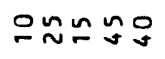 & 으으임유 & 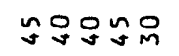 & 음으무는 & 으욤요 & ${ }_{m} \approx 0 \approx 0$ & 음앙ㅇㅇㅇㅇ & ñoㅇㅇㅇㅁ \\
\hline 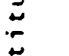 & 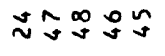 & $\tilde{m} \tilde{m} \bar{m} \tilde{m} \bar{m}$ & $\bar{m} \bar{m} \stackrel{\sim}{\sim} \stackrel{0}{\sim}$ & $\stackrel{\circ}{\sim} \stackrel{\infty}{\sim} \stackrel{\infty}{\sim} \bar{m} \bar{m}$ & $P_{m \sim ⿻}^{\infty} \approx \sim$ & $\stackrel{\sim}{\sim} \sim \sim \bar{\sim}$ & $\stackrel{0}{10} \div$ & $\simeq \approx \simeq \simeq \bar{m}$ & $\bar{m} \dot{m} \tilde{\sim} \approx \dot{m}$ \\
\hline ב & 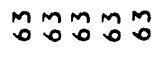 & 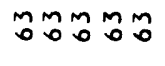 & 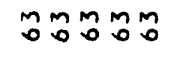 & 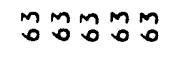 & 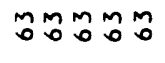 & 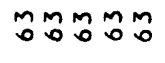 & 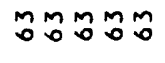 & ตั Mำm & 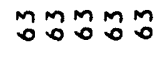 \\
\hline 竞 & 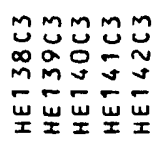 & 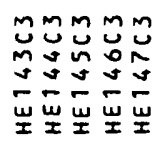 & 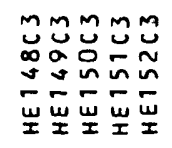 & 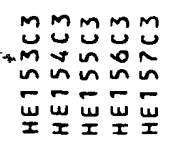 & 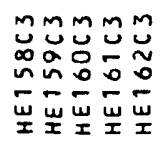 & 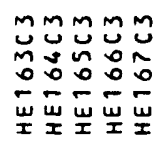 & 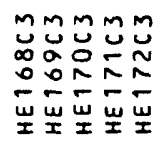 & 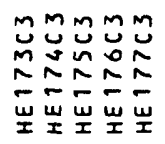 & 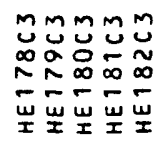 \\
\hline
\end{tabular}


웃ㅇㅇㅇㅇㅇㅇ

\section{응응응으 은옷은으}

은융ㅇㅇㅇㅛ

온은옹은

었운으은

웃유응으

음유음

옹으웅유우

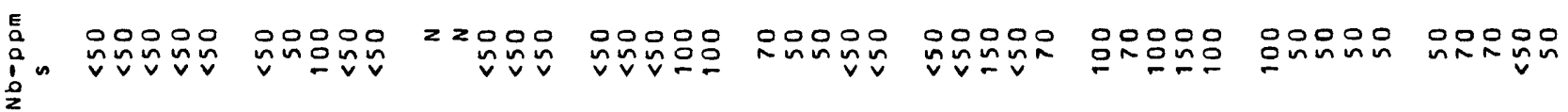

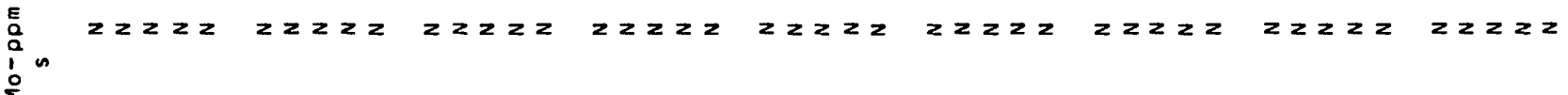

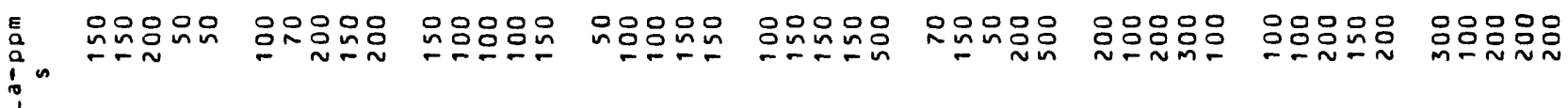

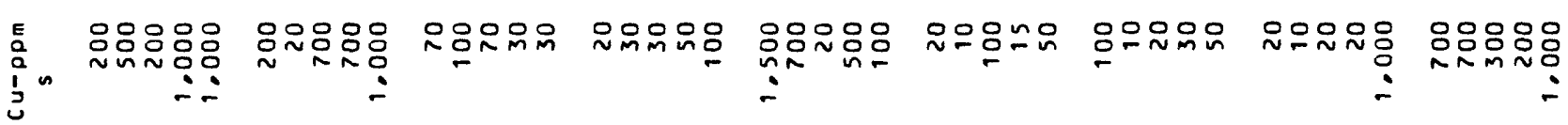

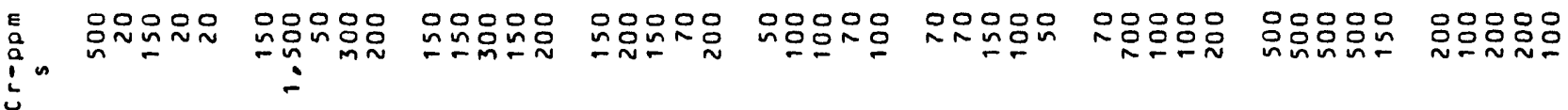

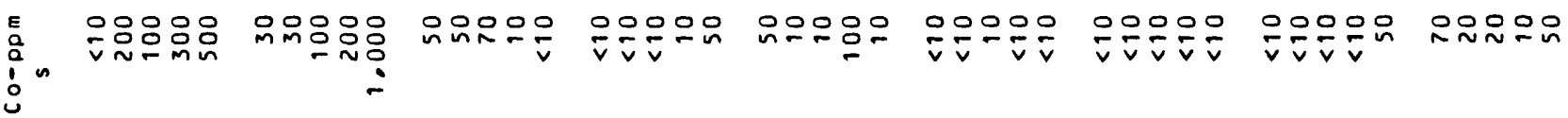
E in

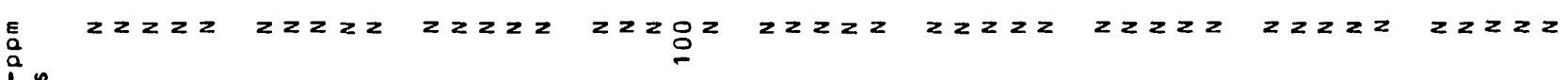
i

E ๓

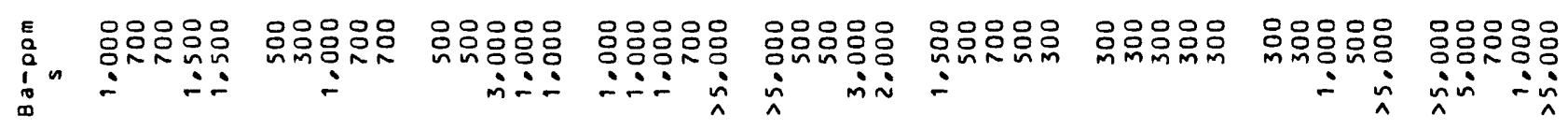

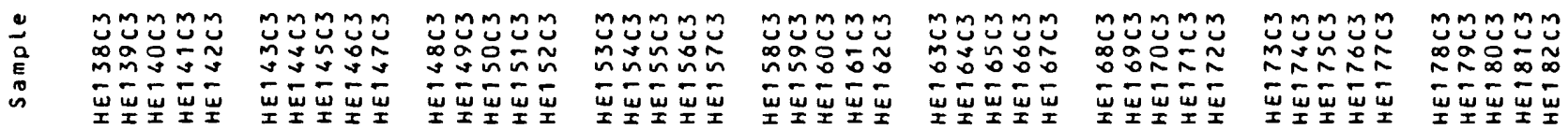




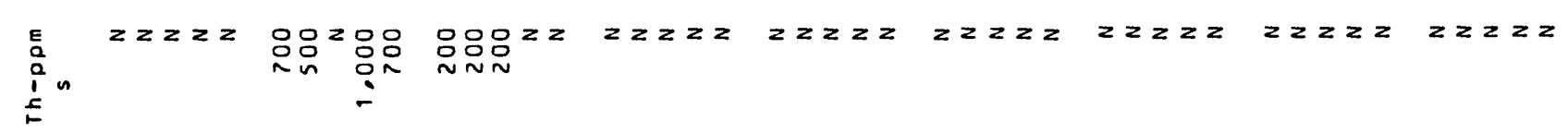




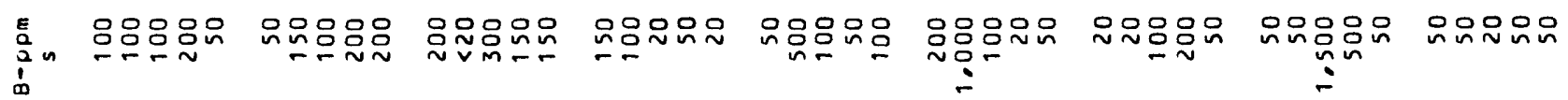

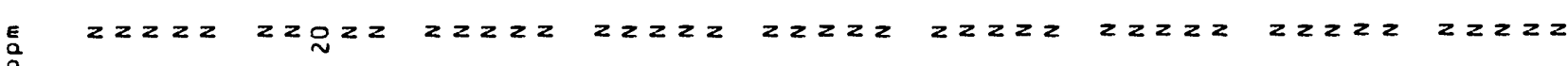
$\sum^{a}$

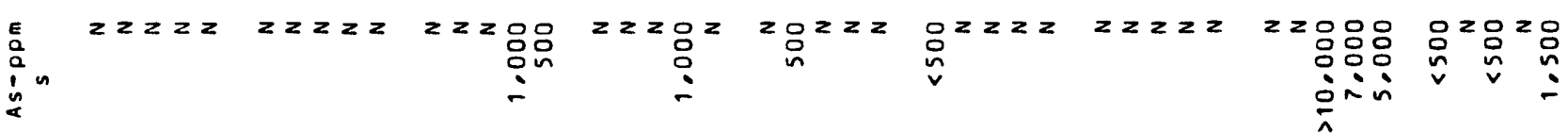

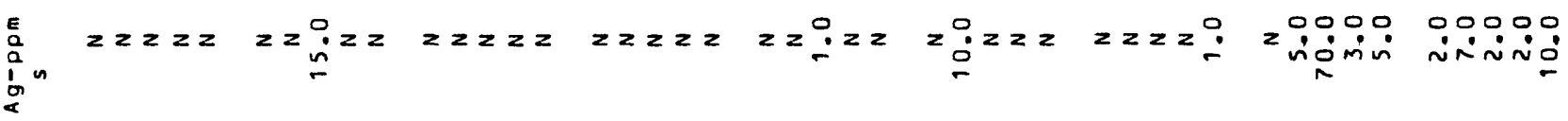

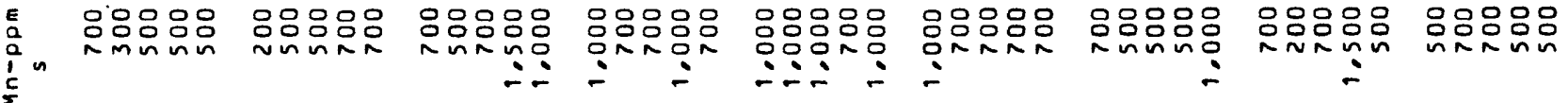

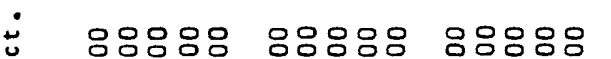

an 응응응은응응응 응응맹으 두숫 $\because \div \div \div$ 두수

응응응응은 옹융ㅇㅇ용요 $\therefore \div \div$ ;

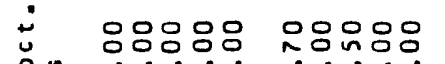
ก-m-n

응웅응응응

응응영응응

응응음응응

응응응응응

옹응응응응

응응응응 inin-m minivin riminir minión ininini nேn்

응응응응응 3

品n

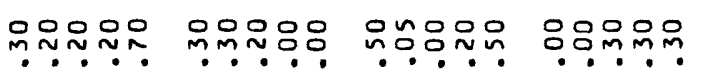

응ㅇㅇㅇㅇ

옥웅으웅

운웅응요

응웅ㅇㅇ

응응은은 $\therefore \because \div$ $\therefore$ $\because \therefore$

0000000000 $\because-$

0.0 .0 .0

0.0000 00000

oogno ninviñ -ĩñ inin-

n்- mं moinim onini

$\because \div \because \div 0$

00000

00000

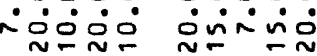

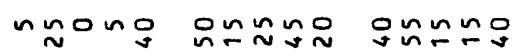

amnNa $\approx \sim ⿻ \infty$

$\infty \infty \infty \infty \infty \quad \infty \infty \infty \infty \infty$

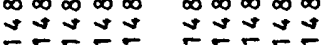

$\checkmark-\infty \infty n$

$\infty \infty \infty \sim n$

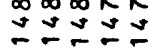

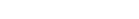

\begin{tabular}{l}
$\stackrel{0}{0}$ \\
\multirow{2}{0}{} \\
\hdashline \\
0 \\
\hline
\end{tabular}

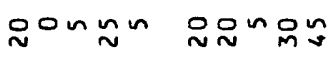

옷요

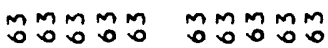

으잉의

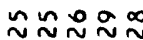

móñ

유은응요

$\stackrel{\infty}{\sim} \tilde{2} \simeq$

ㅇำกำ

$a \cong \infty \infty$

Mूตั

ニேニ

Mำ

mmmmm

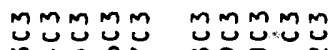

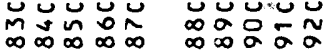

뻐⼟홇

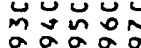

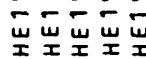

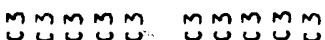

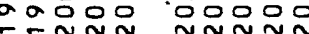

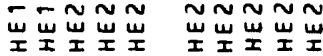

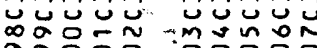

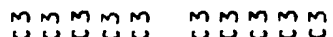

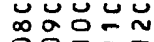

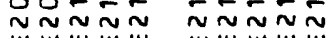
岂岕岕㟧㟧
오ำㅇํำ $a=\simeq \simeq a$

กิำ

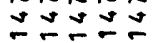

no요의 $\because M M \cong \tilde{m}$ MMMmM

ำกำ ํำ品解 Mำ

mmmmm 느음는

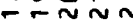
$\sim \sim \sim \sim \sim$ 㟔㞬㞬㞬岌
그의응 오ำกํำ

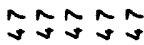

읐등요음

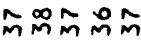
ติำตำ

MMmMm

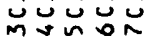

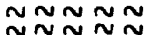

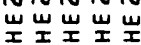




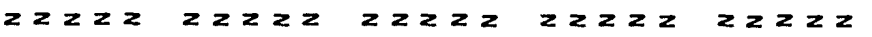

$z z z z$

$z z z z 2$

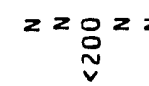

$z 2 z \geq z$

$E$
$\vdots$
$\vdots$
0
0

우웄웅ㅇㅇㅇ

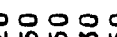

은잉ㅇㅇㅇ

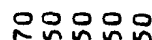

웅음운

음으음은

유ํํํํํำ

웃ㅇㅁㅇㅇㅡ 음요음

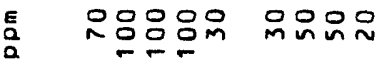

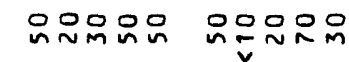

옹요유우

유분뭉ㅇㅁ

으으으우운

옹유윰유

음옹ㅇㅁㅇㅠ

$i^{1}$

$i_{\substack{0 \\ 0}}^{0}$

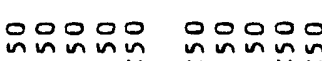

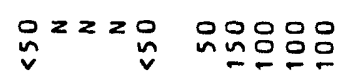

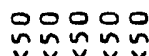

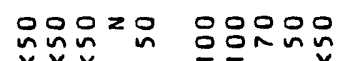

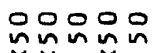

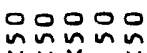

E⿱

$z z z z$

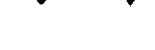

マレレ

$\vee v$

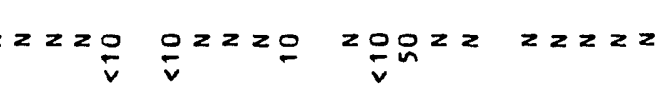

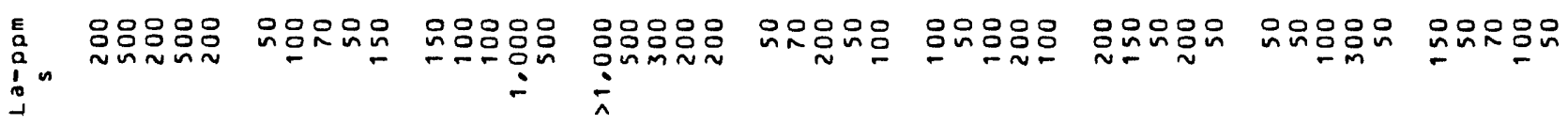

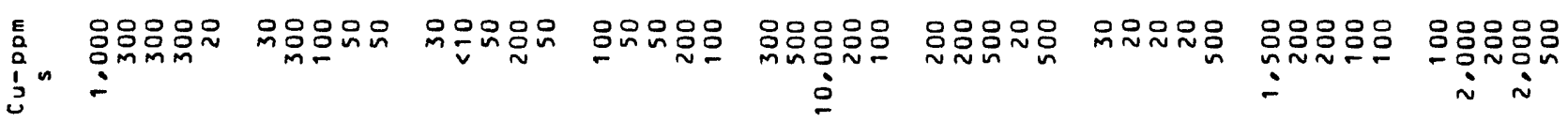

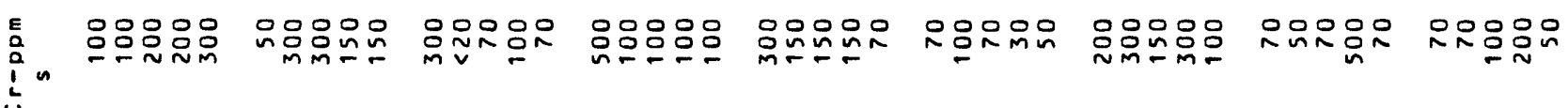

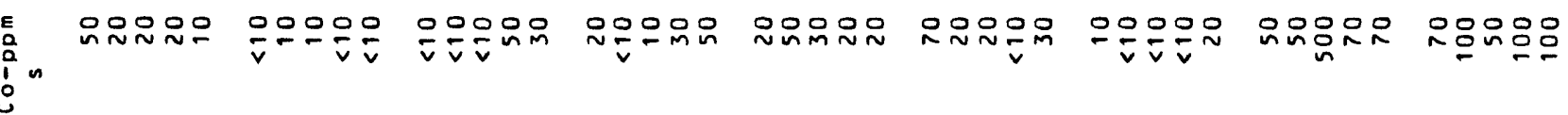

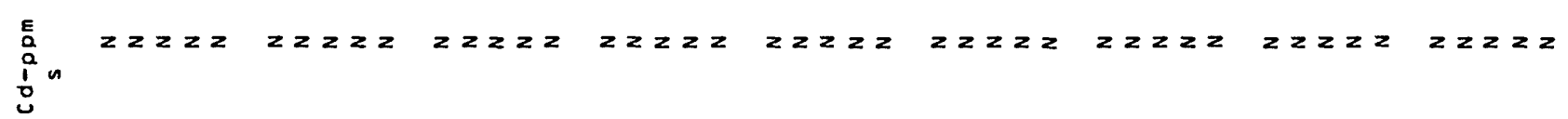

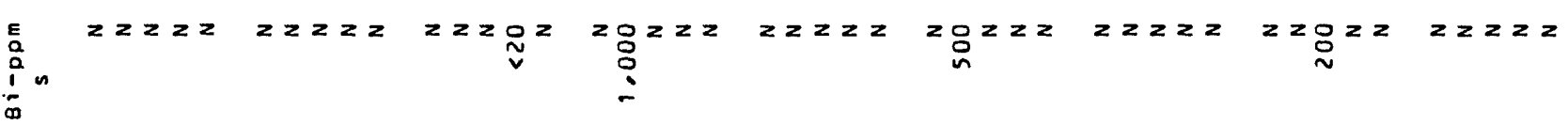

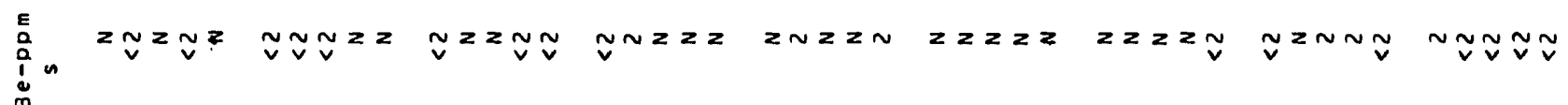

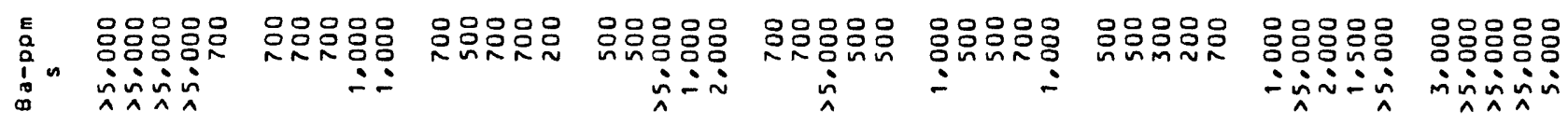

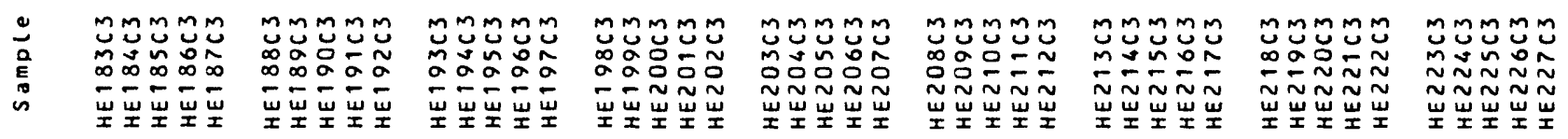




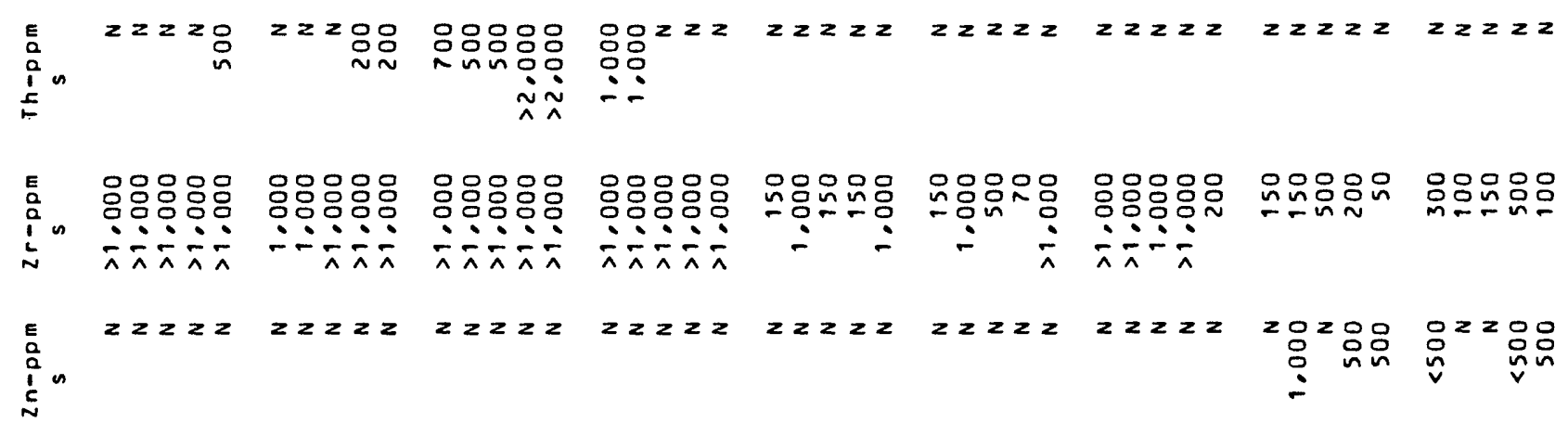

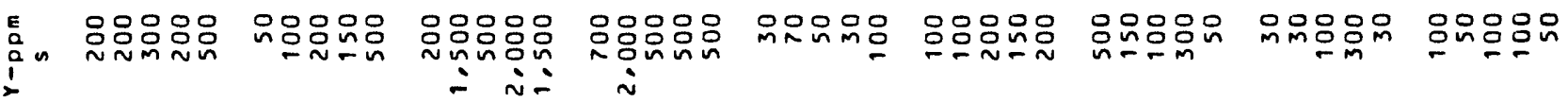

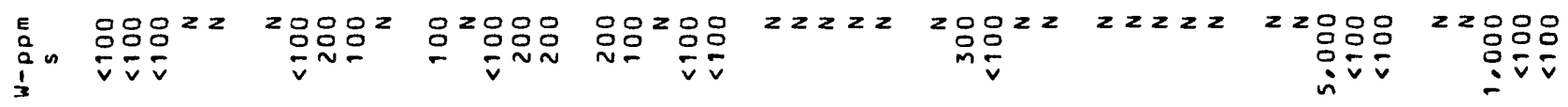

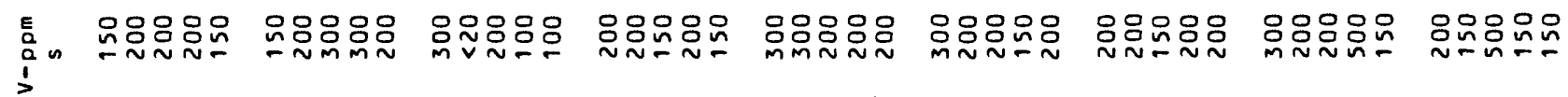

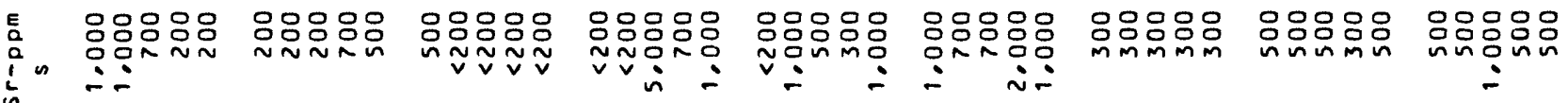

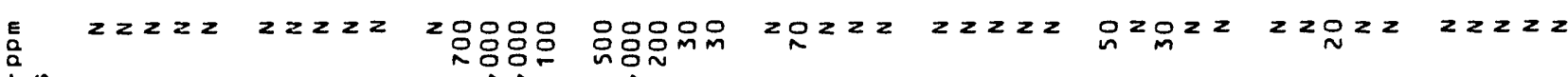
$\underbrace{\substack{a \\ c}}_{\substack{a \\ c}}$ 玄京玄

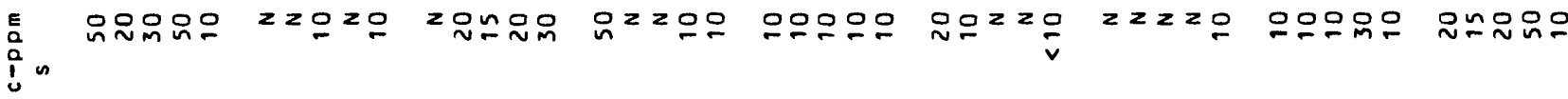

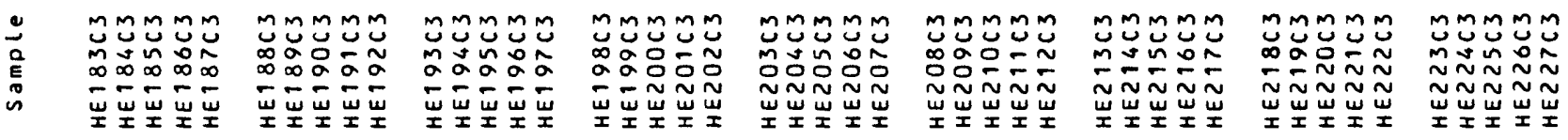




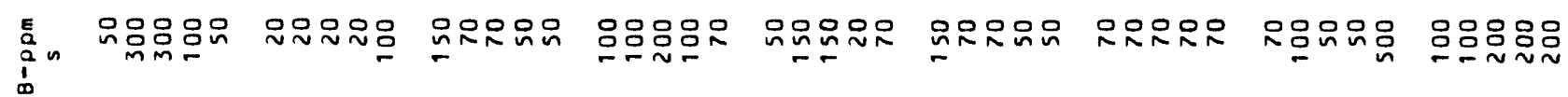

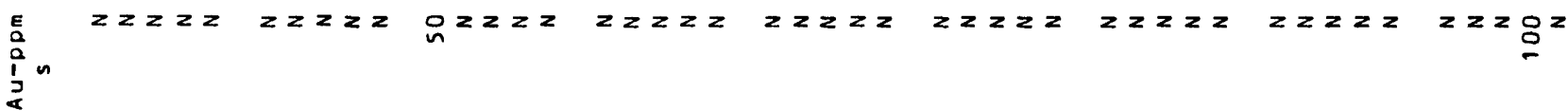

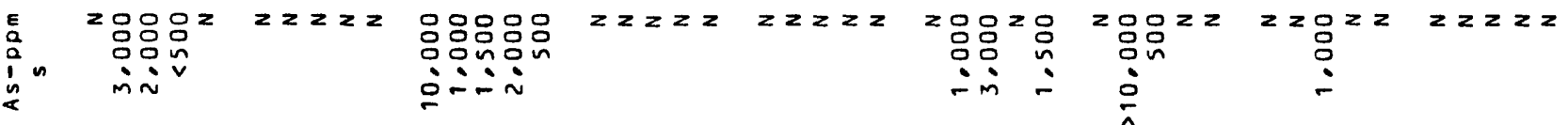

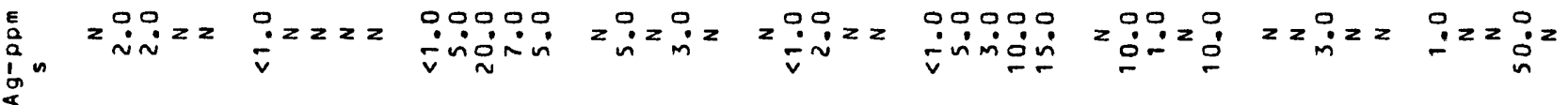

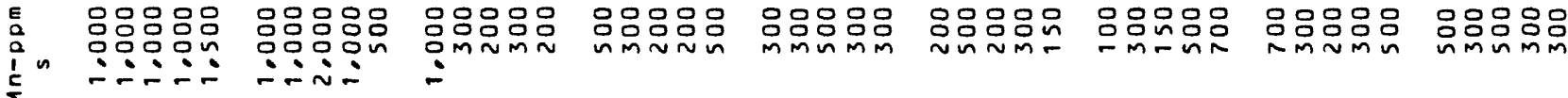

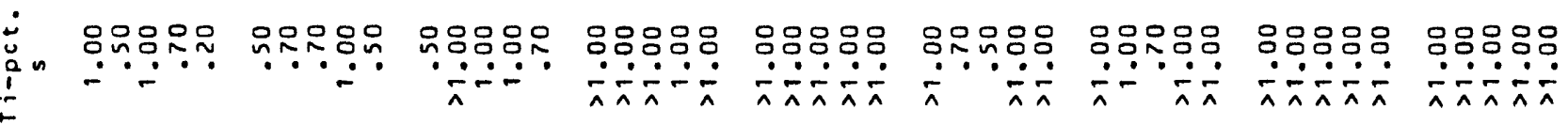
$\ddot{\vdots}$

\section{응응응응 응응응응응} 응응응응으 is vivimi nivivin $\therefore \dot{\sim} \dot{\sim}$

응응옹우 온응우우

응ㅇㅇㅇㅇㅇ응

웅응응응

응

영음응 응영영응 3

is

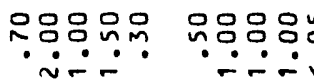

눈뭉뭉

은은문

은윤은은

ำํํำ

ㅇำำำ

은음유응

은오온

:

0000 ㅇํำ

웅․․․․

0.000 .0

$\because$ 문?

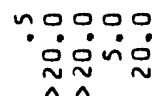

00000

욤ำ

on 000

00000

àn miñ

-

只只只只

- inion

n

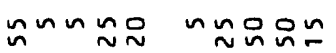

$\simeq \approx n \operatorname{con}$

noำㅇำ

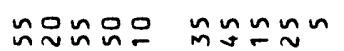

$\infty \infty \sim 0$

-으문

느능ㅁㅇ

«ñกno

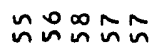

ง nmin

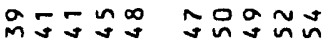

nn $00 \infty \infty$

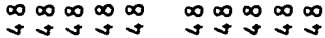

$\infty \infty \infty \infty \infty$

ษฐษ

nn $\infty$ on

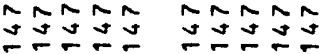

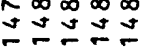

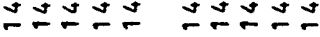

さேさェさ゚

テンテンュ

$\sim \infty \infty \infty$

レேンテン

non moo $0 \simeq \simeq \sim r$ $\infty \infty \infty \infty \infty$

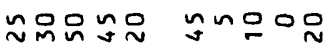

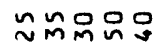

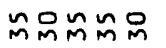

ํำำำ

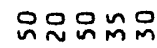

이유ำ

nทnฺำ

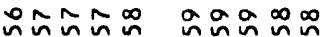

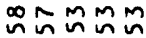

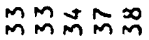
舫的旅品

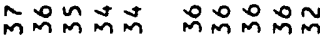

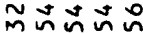
móñ mom

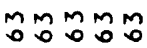

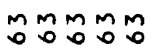

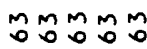

mnogn

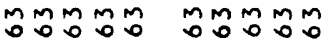
mô

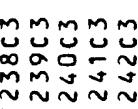

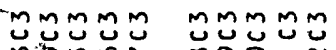

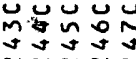
$\dot{\sim} \sim \tilde{\sim} \sim \sim$

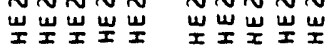

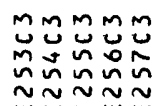

mự

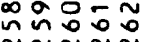

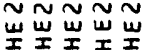

MMMMM

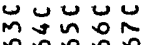
$\sim \sim \sim \sim \sim \sim \sim 乛 亅$

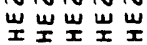
MNNNNNM

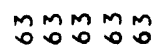




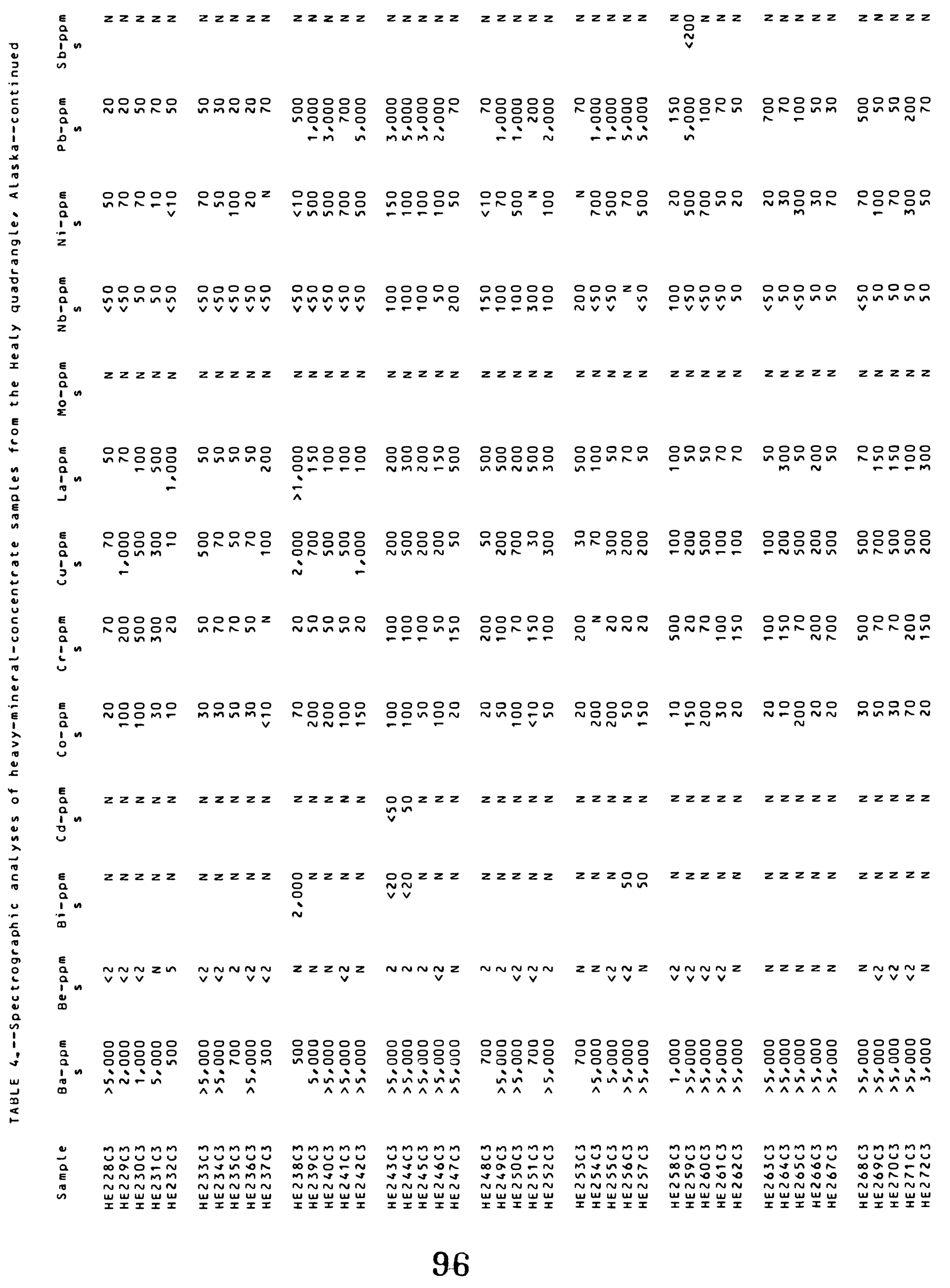




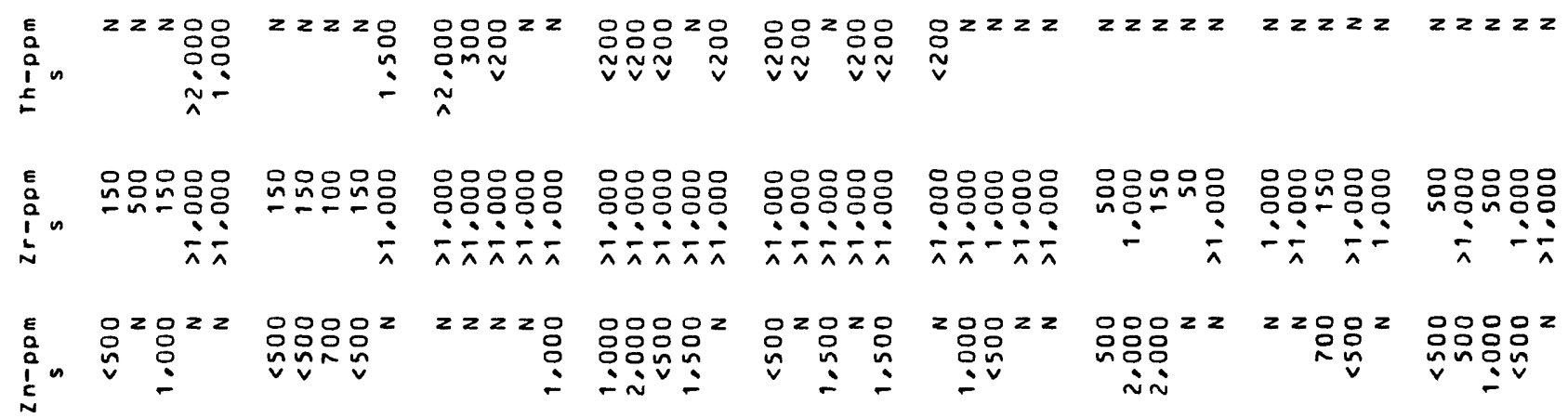

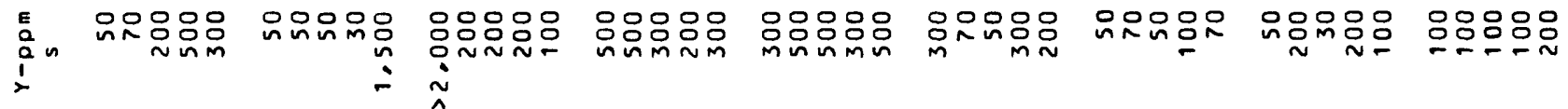

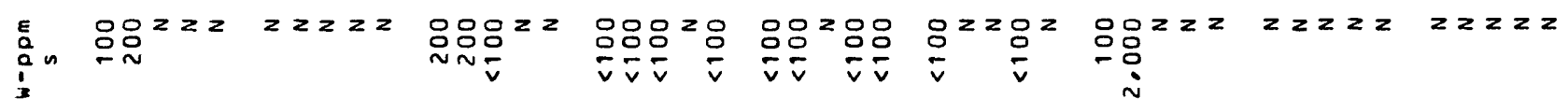

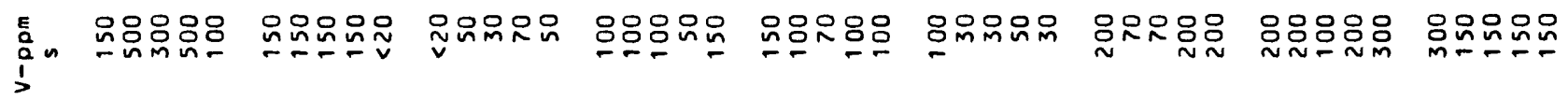

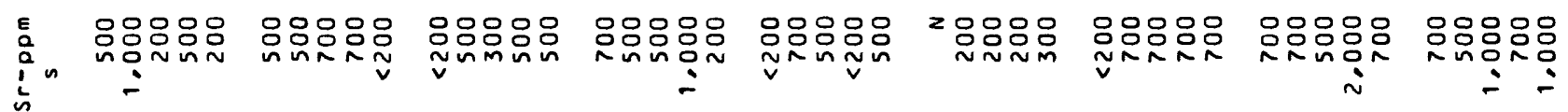

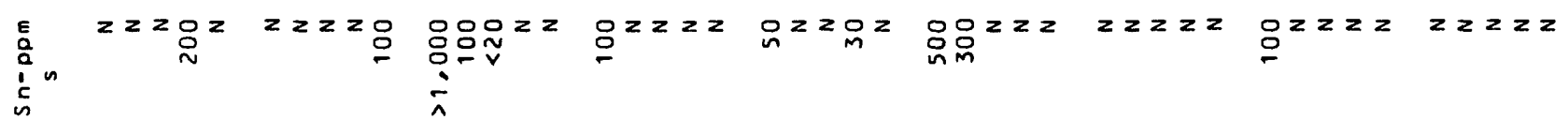

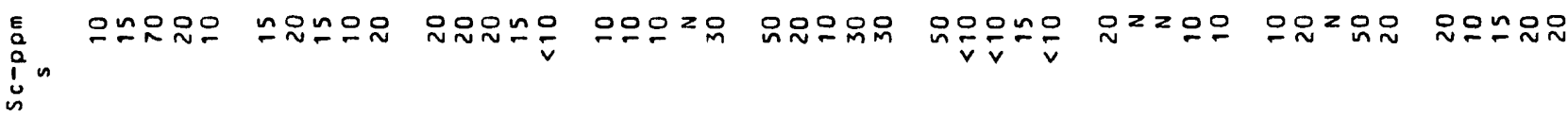

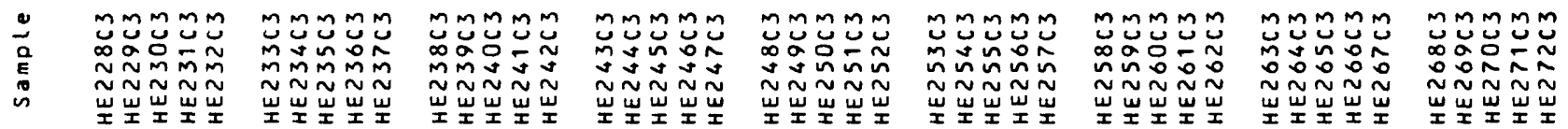




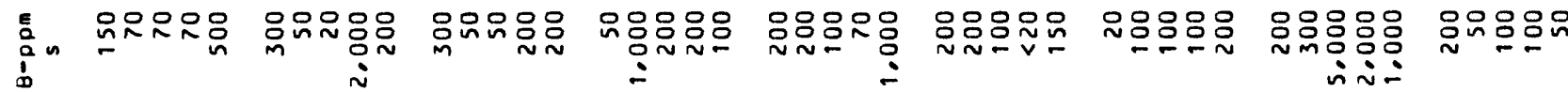

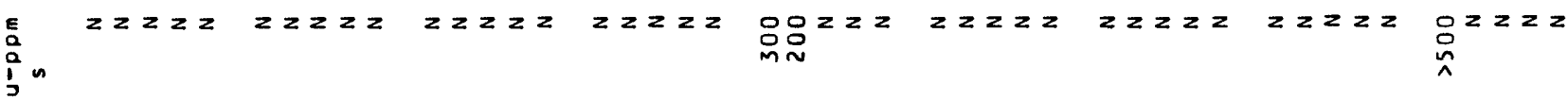

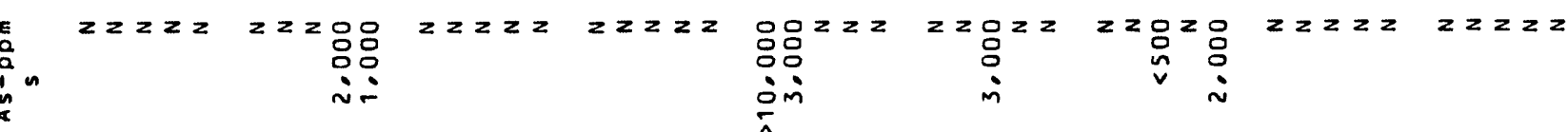

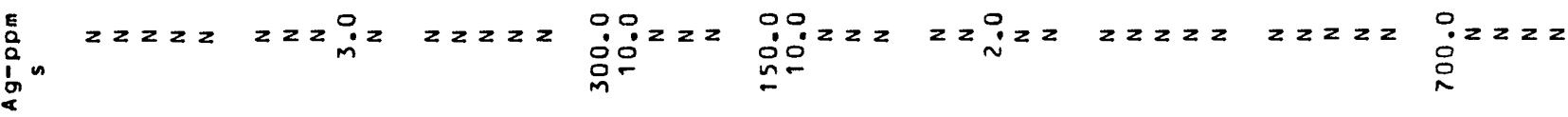

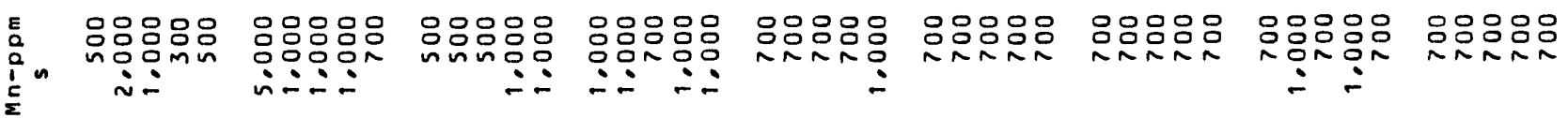

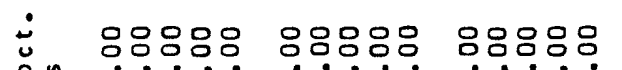

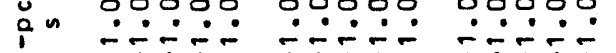
응응응응응 응옹음응옹 $\therefore \div \div \div$

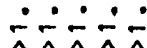

옹옹옹응

응음옹옹응

옴옹으붕ㅇ

은옹응옹으

옹응응은응융응 an ㅁํำ ทำ? 옹응응응

응옹음음

응응용음 $\div \div \div-\div$

$\therefore \div \div \div \div$

$\therefore-$

$\therefore \div$

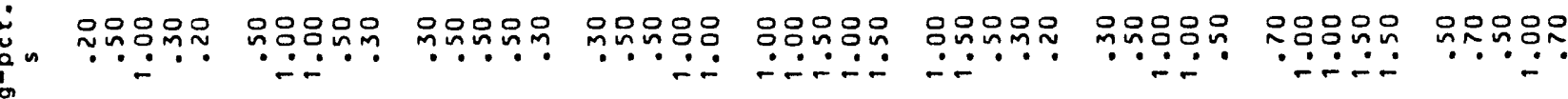

$\dot{0}$
ann
$\vdots$
$\vdots$
$u$

0000000000

00000

ogonn oonoo

onono

onn no

$0000 n$

응영응응 응영응응

옹응응응 inini ringón ก Nmiñ

nñ⿻-<smiles>[Te]=C1CCC1</smiles>

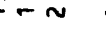
- $+\cdots$

iñ

$0,0 \operatorname{nno}$

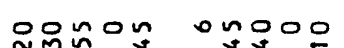

$\sim m a+\infty \quad a a \cong 0 n m-\infty i n$

$\infty \infty \sim \infty \infty \infty \infty \infty \infty$

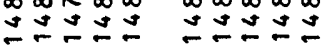

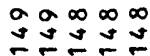

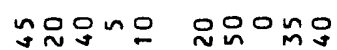
은 $\backsim$ 움이

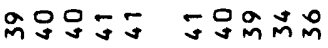

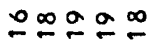
mू̆

mó

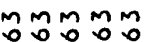

ะำ으웅

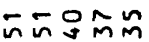

noำกำ

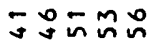

욛ำ

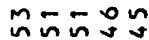

$\infty \infty \infty \infty \infty$

$\infty \infty \sim \sim$

ヘNNN

ヒேさンさ

さேンュュ

シさささき

onn no

mกs

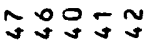

กิก ก

エேさンン

응유은

nno nu

으ำn

ninoㅇㅇㅇ

은ㅁN

는으

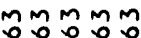

onON

man D

응으은으

느웅음ํำ

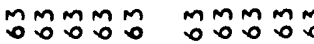

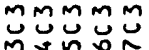

ตํํํㅇํำ

mww $w_{w}^{m} w$
ํㅗํํํํํำ

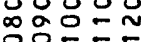

있ำ的 出出w
운으은

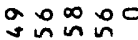

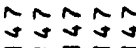
웜ำ

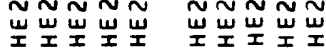

$\sim \sim m M$

w山्
MMMMm

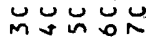
m的的的 w鰎 


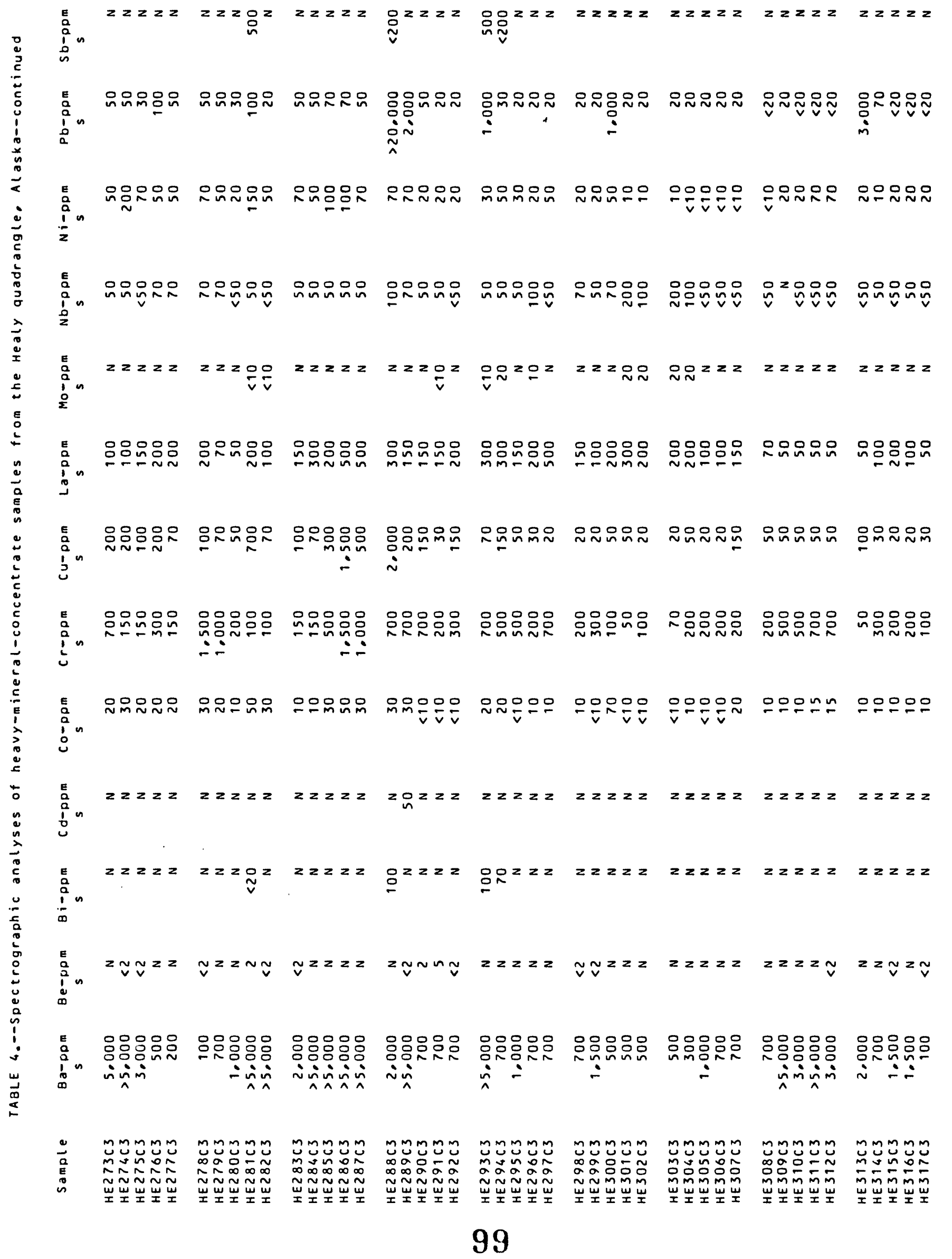




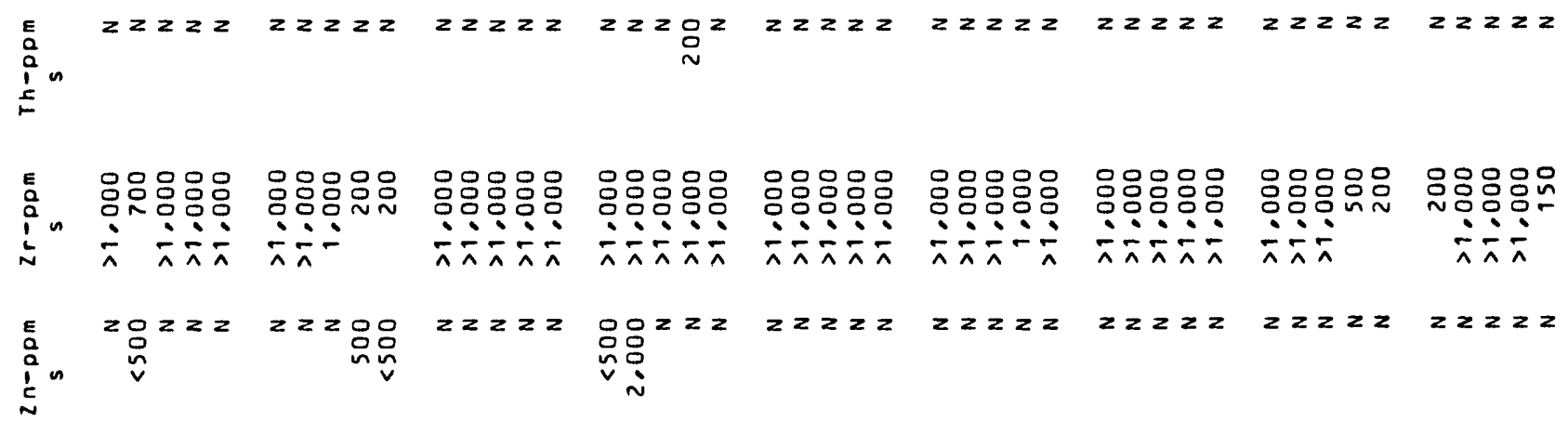

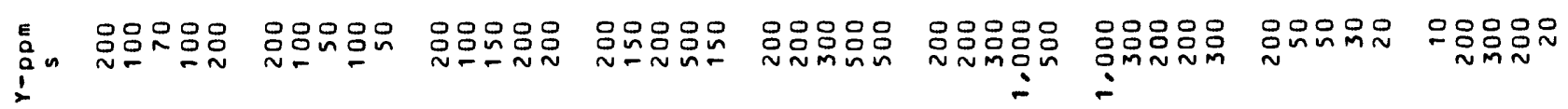

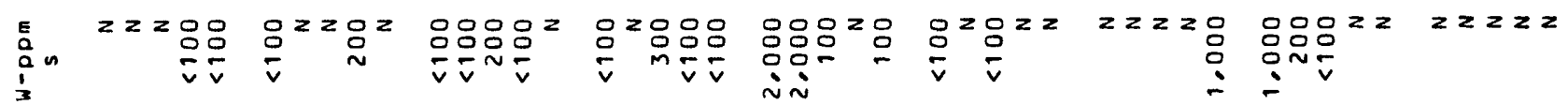

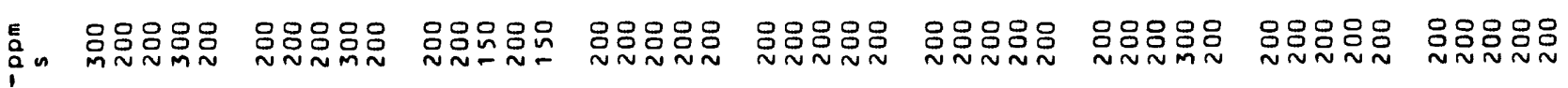

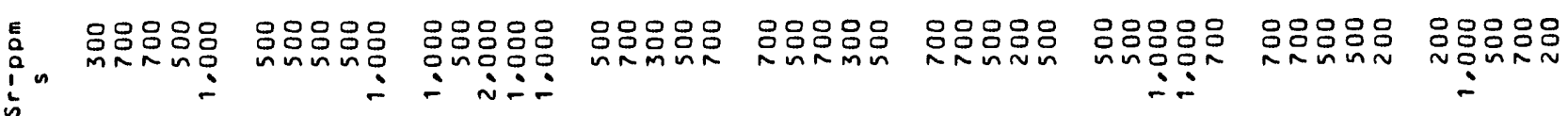

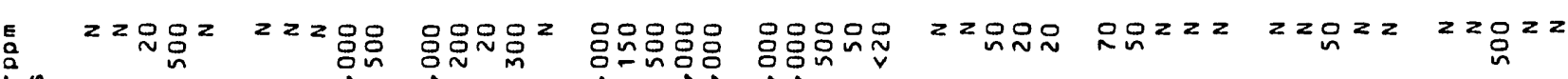

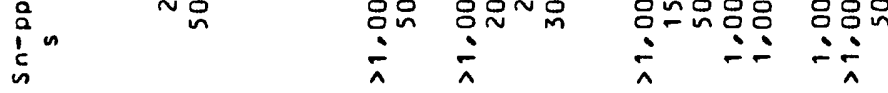

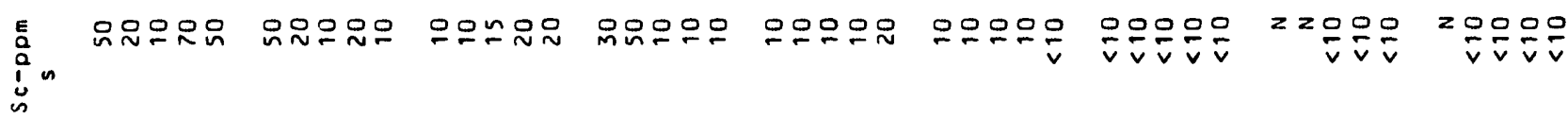

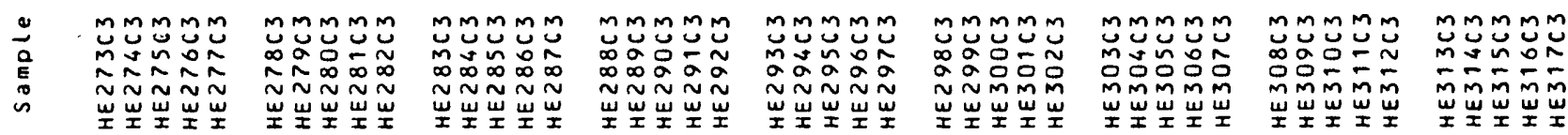




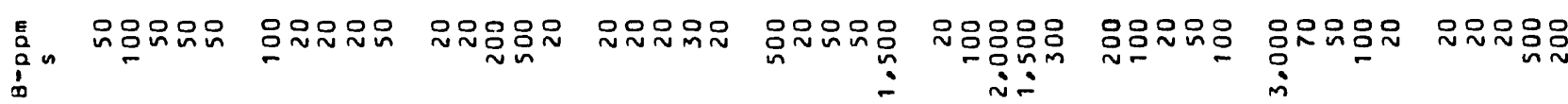

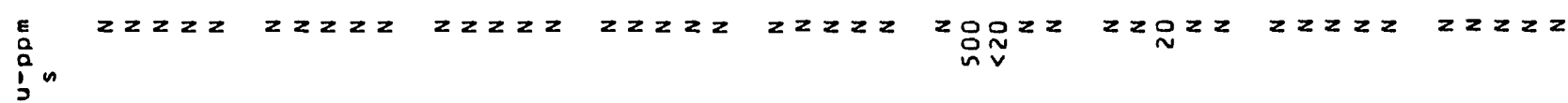

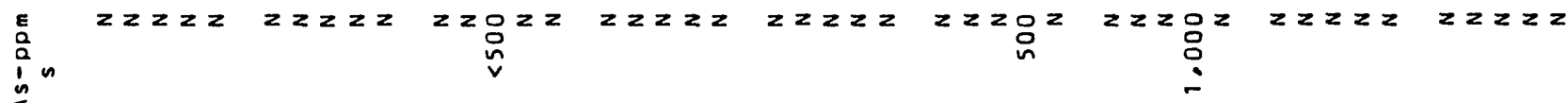

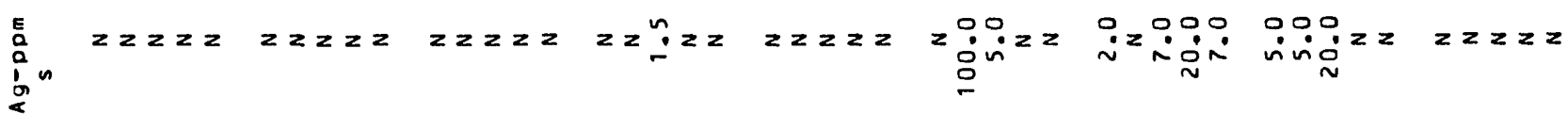

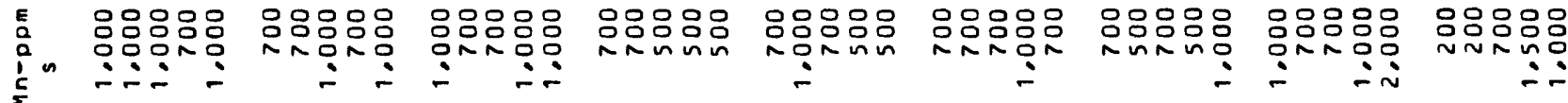

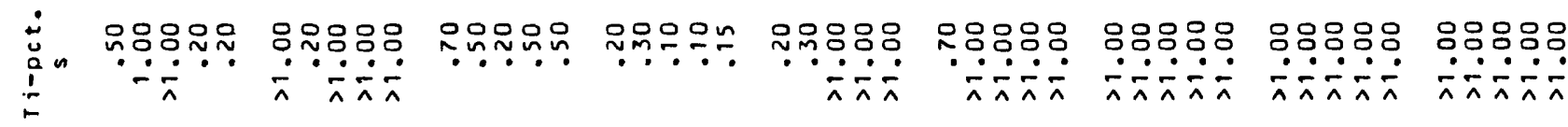

in 옹용ㅇㅇ 옹응응 응응응 응ㅇㅇㅇㅇㅇㅁ 옹ㅇㅇㅇ음 응응영응

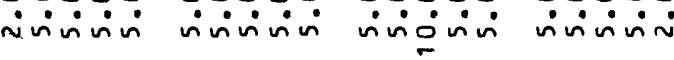
¿่miniv

응응음

응응음

옴옹용ㅇㅁ $i_{0}^{2}$ nivinis กัท่ที่

minivi:

minimin ininis

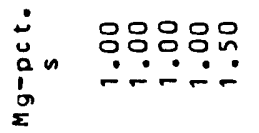

응응ㅇㅇ음

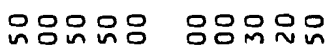

옹용ㅇㅁ

웅ㅇㅇㅇㅇㅇ $\because \because$ $\because \therefore$

욱으능ㅁ옹

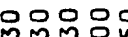

웅우오음 $\sim-\cdots$ ำ-

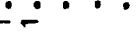
-

$\dot{a}^{a}$

0000

noooo

00000

$0000 n$

00000

00000

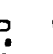

noo 00

0.0900

00000 u

은ำำ

엉웡ㅇㅁ용

음음ㄷ

ทำำก

ng요의

$\approx n \approx \sim \sim n n$

$\sin (\pi$,

noñon

gunñ

๓ก๊ํํำ

000ma -

NANล음

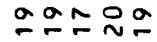

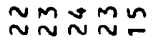

ํㅜ둥

$\bar{\sim} \approx \sim \sim \sim m$

$\tilde{n} \sim \infty \sim ⿻ \infty$

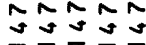

ษ์ฐ์ฐ์

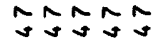

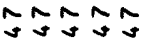

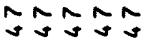

ริฐ์ิ์

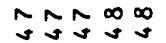

$\infty \infty \infty \infty \infty$

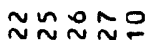

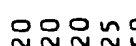

Dinooo

ognnn

nonsm

mNmos

OUNa

gronnm

oonon

noํ응

noopo

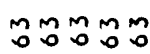

คุmmpm

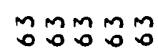

nonun odod

드으으=

뜨들

유ำณำ

$=\simeq$ 으응

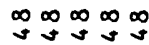

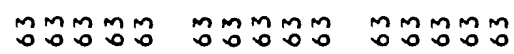

ำ

Mำmm

웄움맘

$0 \infty 000$

ตำำ?

Mํํํํำ

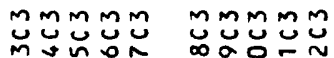

m的的m

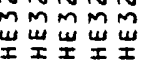

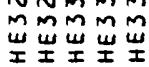

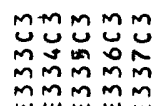

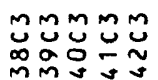

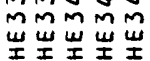

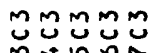

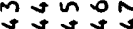

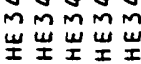

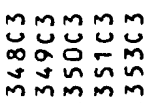

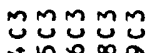
in

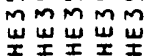

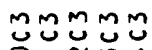
O- Nmy mmm的的

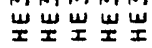




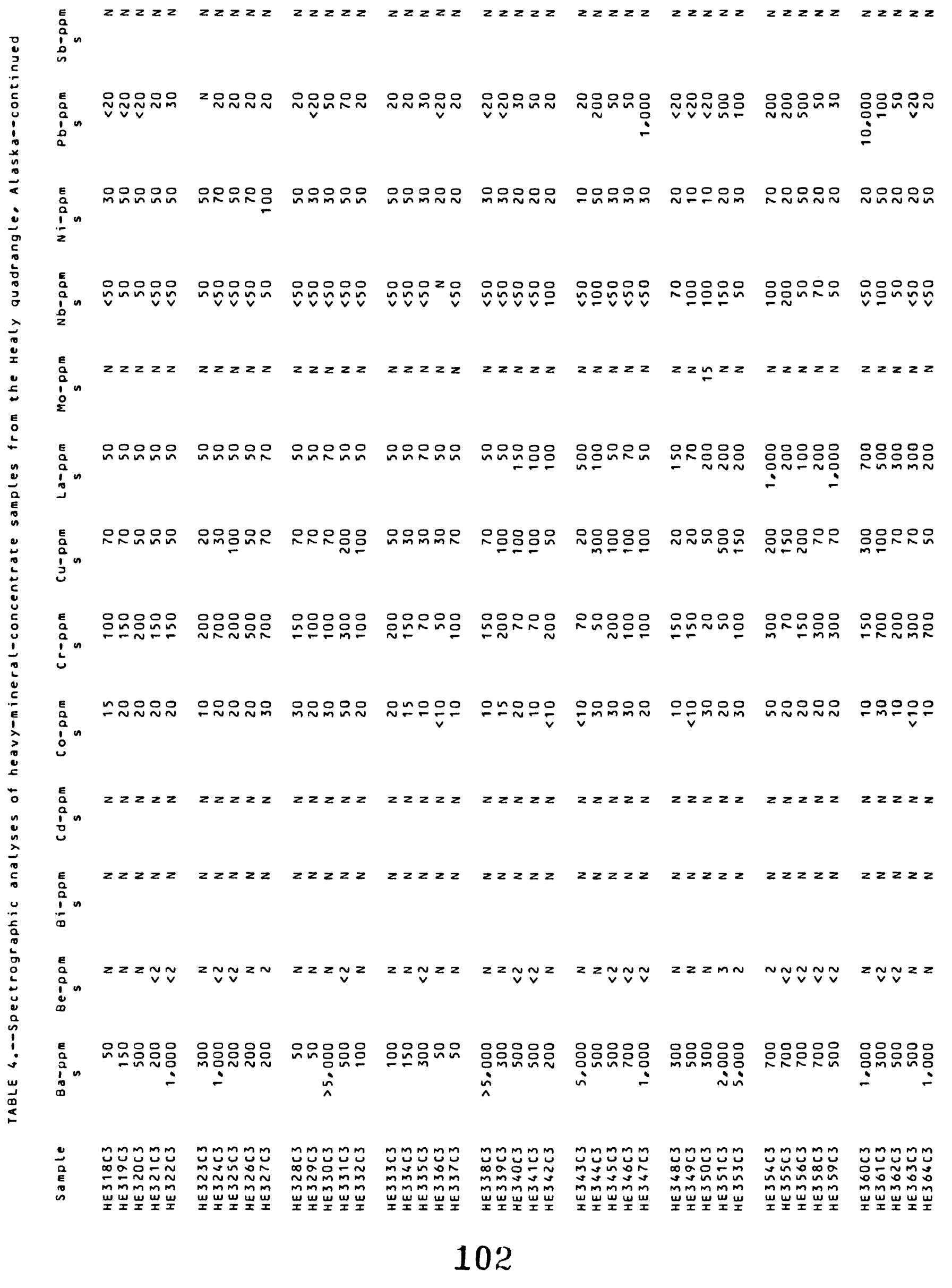




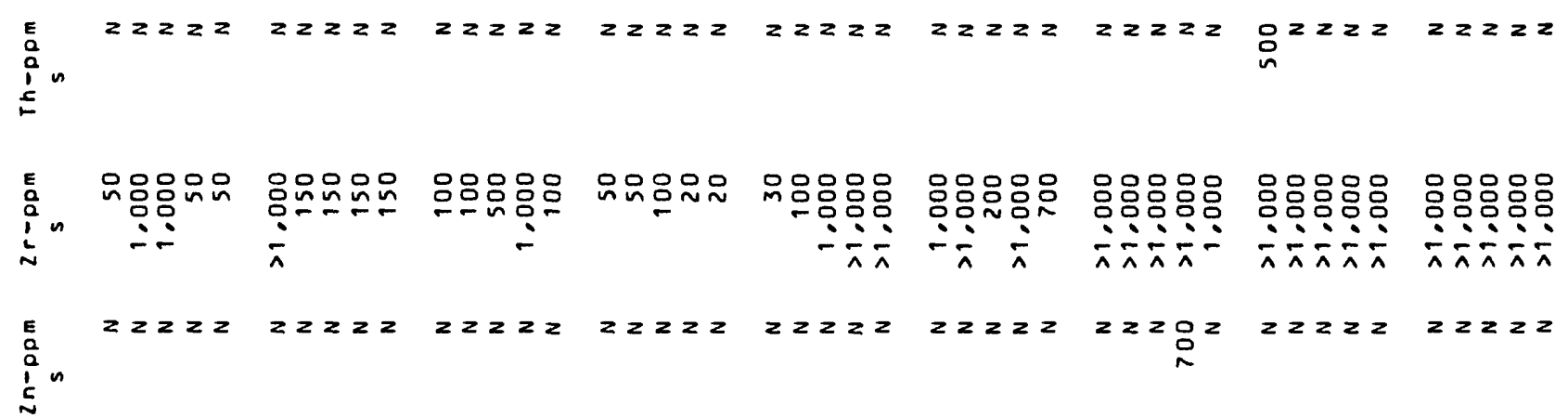

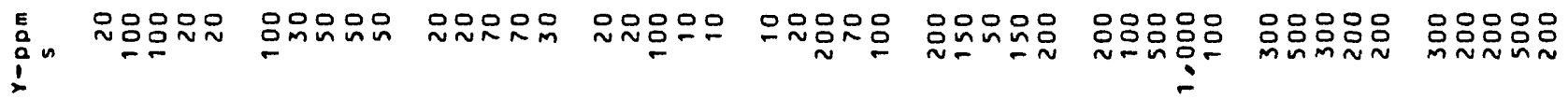

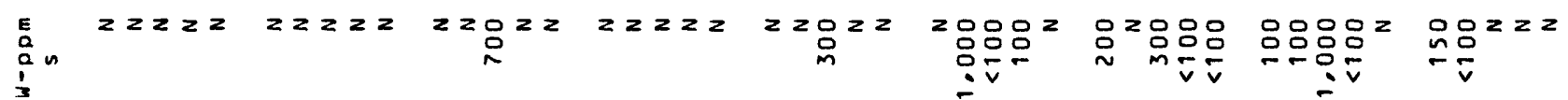

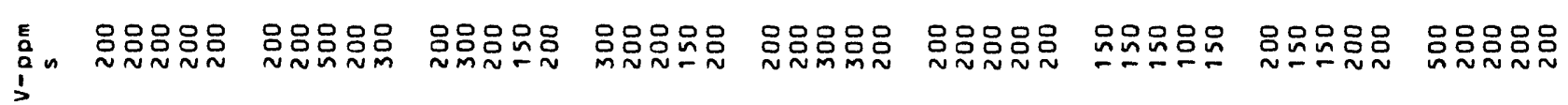

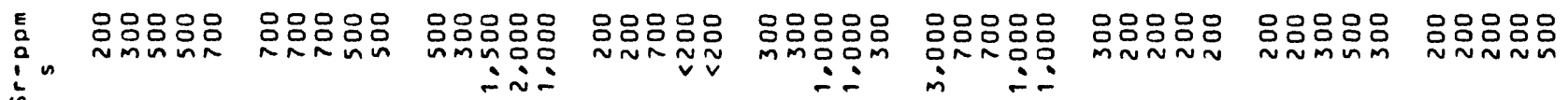

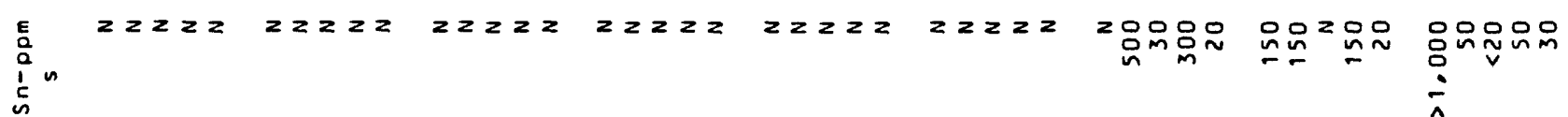

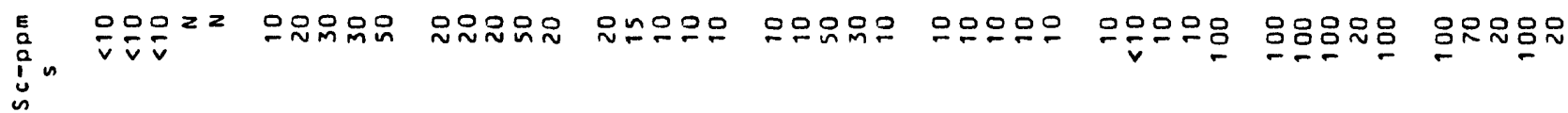




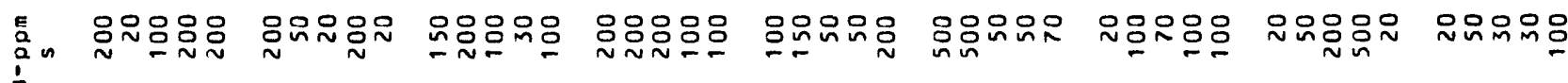

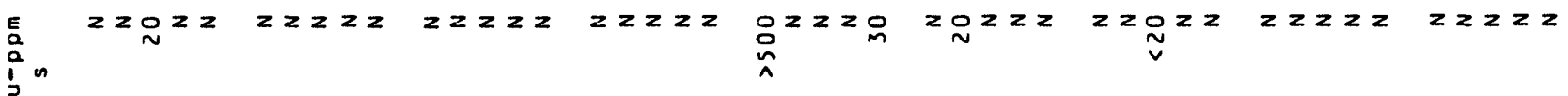

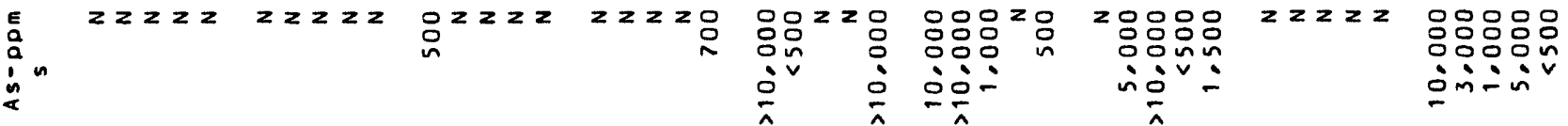

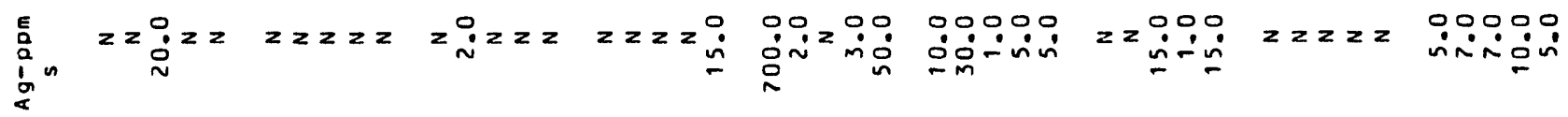

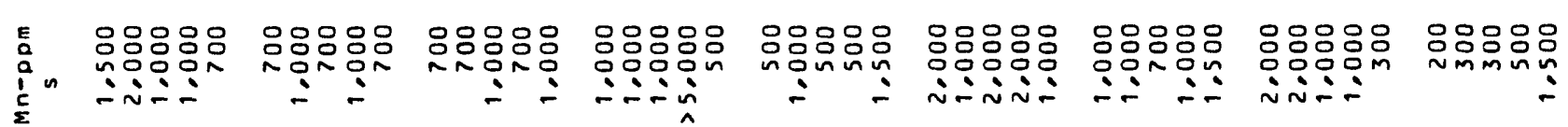
i 용용ㅇㅇㅇ 웅응으

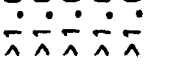
oำกำ 응응응웅으

00000

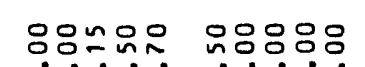

응웅응우

웅요옹

은유윰요 $\leftarrow$ $\pi$ 추수 $\therefore \dot{\wedge} \div$

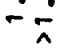
$\because \therefore-\div$ $\therefore \div \div$

: 응응응응 응응응응응 응응응응

응응응으 응융ㅇㅇ응

응응응응응

응응용ㅇㅇㅇ

옹응응응응

은으응ㅇㅇㅇㅇ o nini in nininim miñn onimi -im. i

نंखिं mimin

iñ - in

00000 00000

00000

00000

00000

었잉ㅇㅇㅇㅇㅡ

\section{8}

응은으응

은음음애읍

응응ㅇㅇㅇ o $\therefore \dot{\sim} \dot{-}$ inஸำ mं :-

$\dot{1} \div \dot{\sim}$

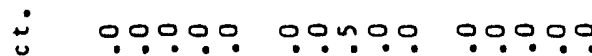

00000

00000

00000

00000

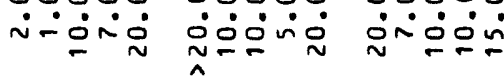

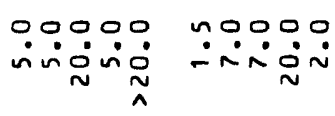

00000 : ก Nmm 웅ํำ

0000n 00nnn

Nan O

$\simeq \infty \pi$

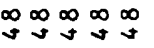

$0 \pm \sim \infty \infty$

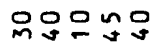

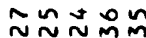

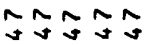

$\hat{y} \tilde{y} \tilde{y}$

ㅇํำn $\sim$

용ำ

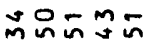

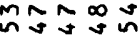

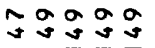

gagag

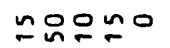

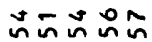

mom $\sim$ 욤

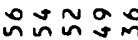

mo moon

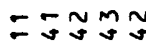

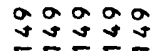

a. 000

agag

arara

ํํำกำ กำำก

읐드음으우

여의의

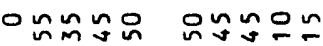

ก음요슨

oo-mo

$0 \infty \infty \sim a$

a $\infty \infty \sim N$

- Omma

M้Mตับ

môn

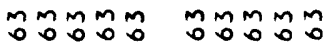

MัM

móñ $m$

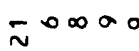

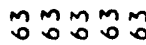

은ำำ ษัปิ๊ก gogag

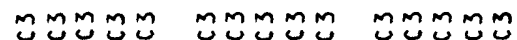

nON

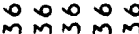

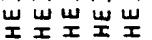

o-N MU

NNNN

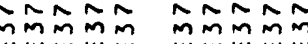

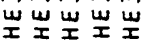

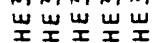

MMMMM MMMMM

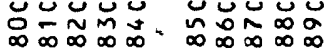
MmMm MmMMm 秘㟧程

mmmmm Oaga w

MMMMM

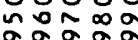

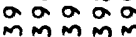

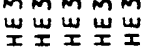

MMMMm

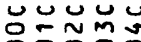

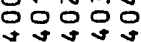

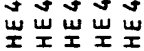

$M m M M M$ in요 연연영 岌岗饪岌岌 


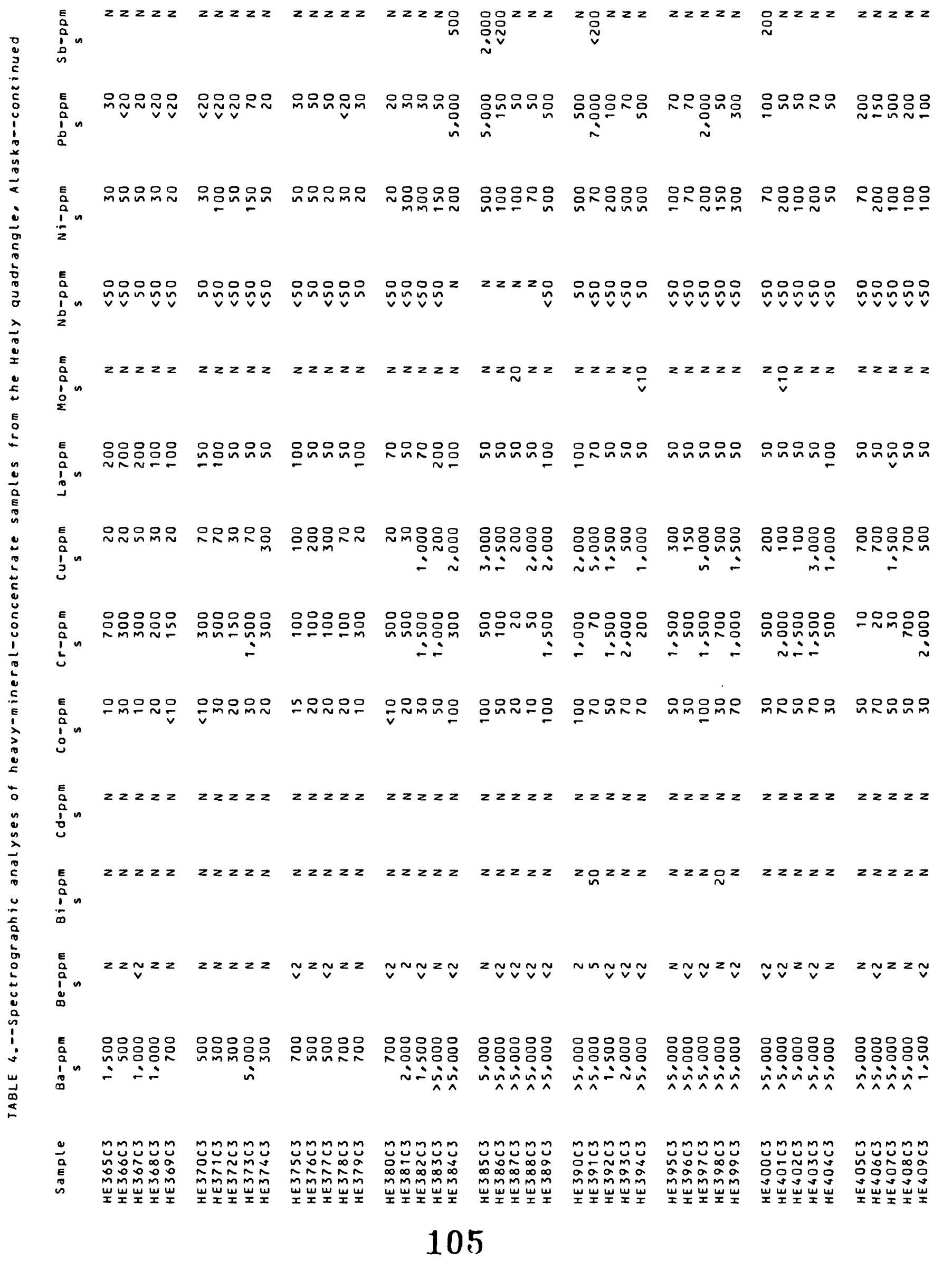




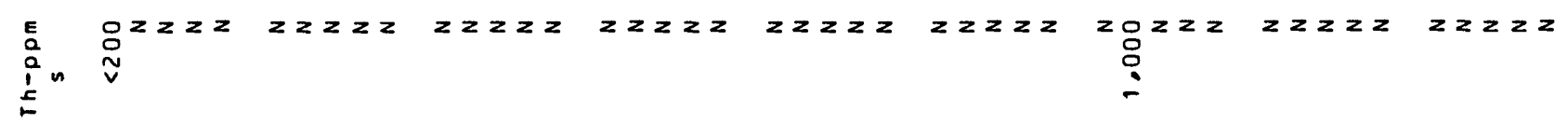

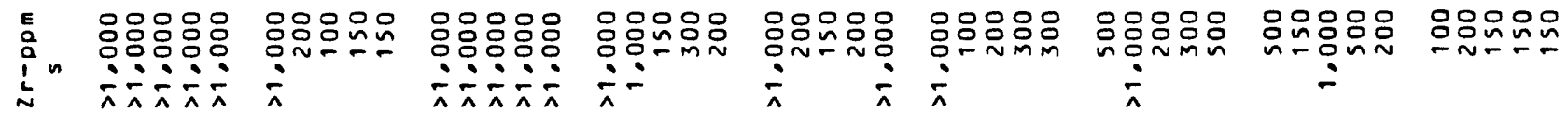

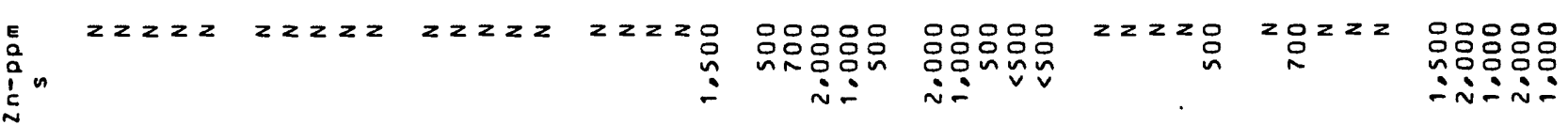

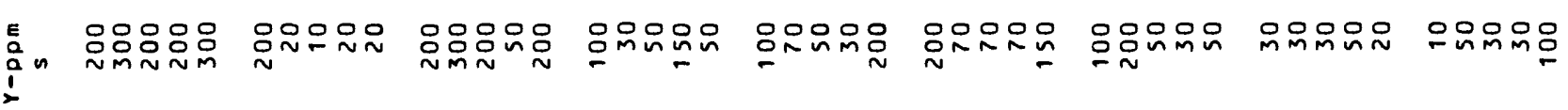

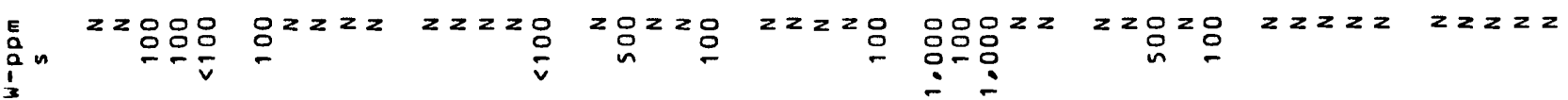

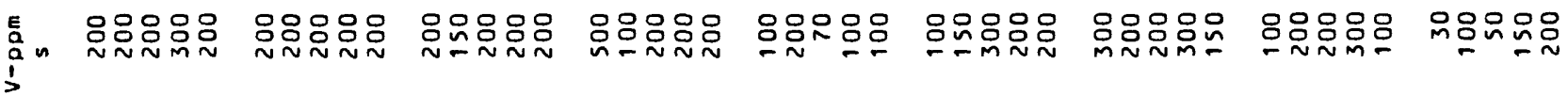

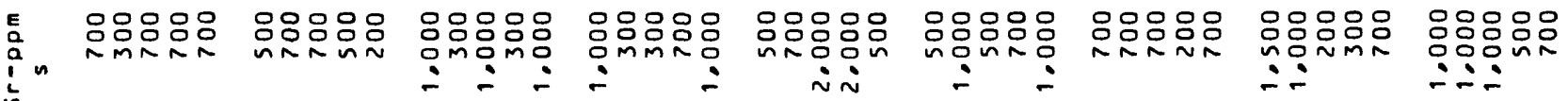

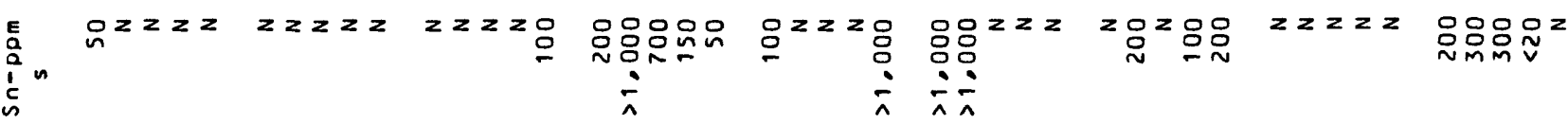

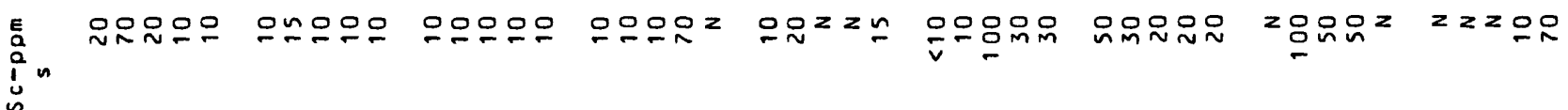

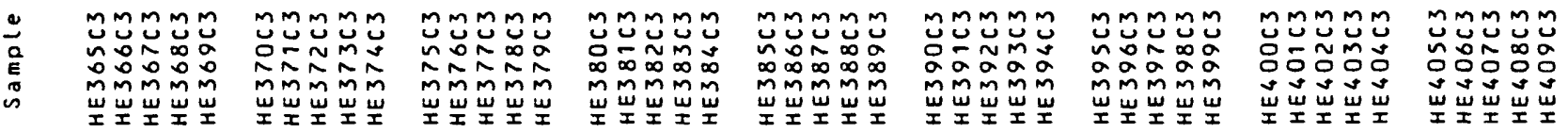




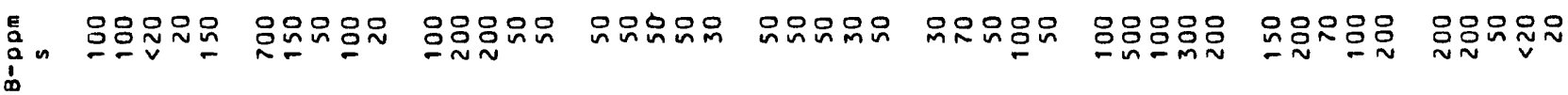

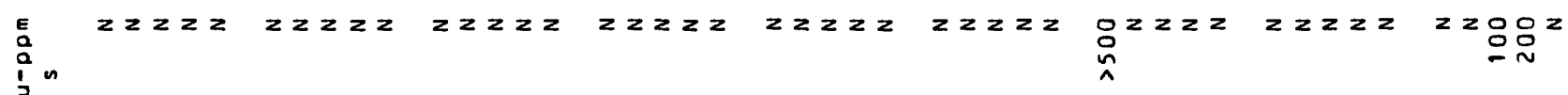
E $\quad$ E

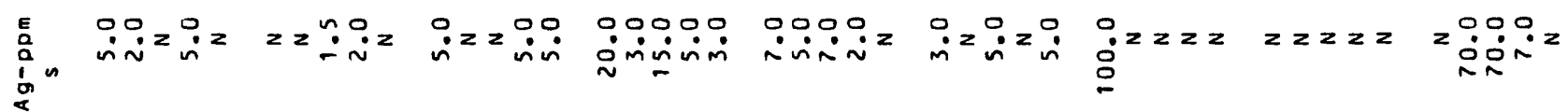

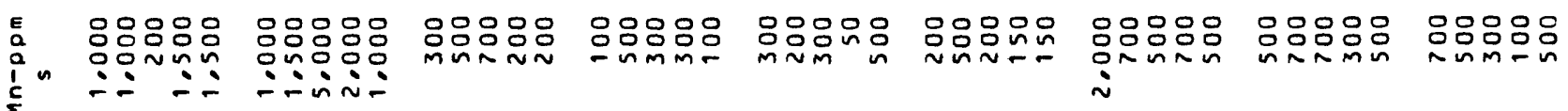

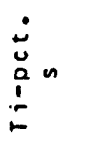

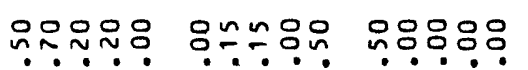

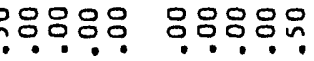
용ㅇㅇㅇ유응 옹응응

응응응응응

웅응응용응

옹음응은응

응응유응 응영응

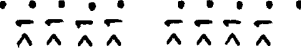

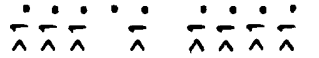
두수

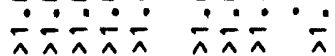
जिं- im minimi $\dot{\sim} \dot{\sim} \dot{\sim}$

응응응영은 ini

웅응응은응

옷응옹응 m-n $\dot{n}$ min-

응응ㅇㅇㅇ웅 miñm

응응응응 miñm

응웅응 ㅁำ?

\section{oonoo} 웅응

:un m응요온 눈ํำ 옹ㅇㅇㅇㅇㅇ 응응 으ำำ 웅ํํ융 운운온오 옹ㅇㅁ응ㅇ ?ำ 은유ํํํำ $\dot{j}$
$a$
$\vdots$
$\vdots$

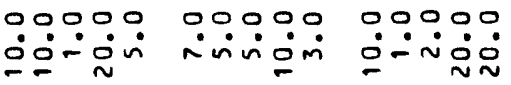
0.0000 ioio: N NヘN

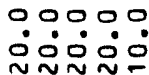
$\sim \sim N$

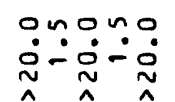

n.0.0

noono -ñn-min-:

$0,0 \sim 00$ 둥-

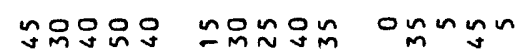
mámiv

agag agaga

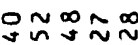
$0 \infty \infty \infty \infty$

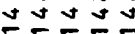

ãava ปンะ

ononn

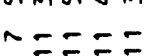

옸음은 monm

oon $\ln 2$ $\pm \approx \tilde{\sim} \tilde{\sim}$

mon

mmmmm

mom

응의온 กีนกํำ

mămm

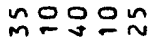

oñ

으르ำ

$\infty \infty \infty \infty \infty$

miña

$\infty \infty \infty \infty \infty$

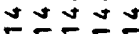

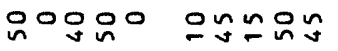

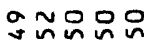
mmmmm 的品昌的 mmmmm

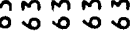

o요ำ

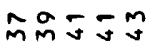
$\infty \infty \infty \infty \infty$ ป士心

ำํํำ

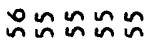

mMmmm 00000
๓

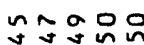
$\infty \infty \infty \infty \infty$

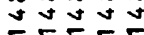

m $\approx$ 잉

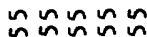
mọmpon
오ำำ $\tilde{n} \sim \tilde{n} \infty 0$

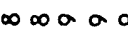
2
$\infty$
$\infty$

ogimnn

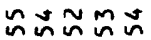

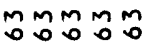

mmmmm mữ

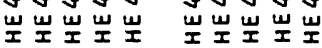

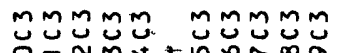

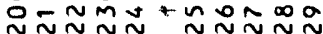

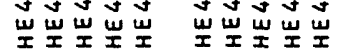

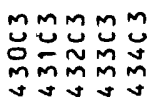

múñữ

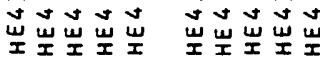

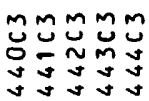
岂岕岕岕岂

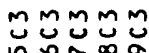
iñ 可讨

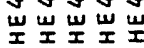

MmMMm 으는

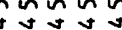

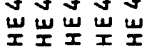




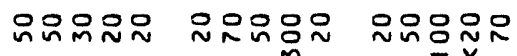

E
$\frac{a}{2}$
$i^{2} n$

웅으융응

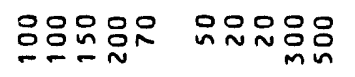

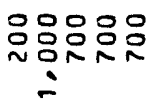

용요

ㄴn

웅음욤

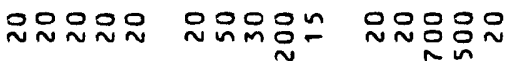

E 0000000000 00000

a

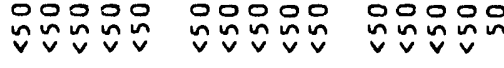

웅요

o0000

$\because \div$

ททที่ที่ที่ที่

욱움웅요

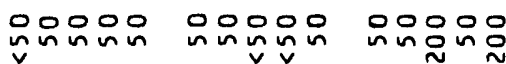

$E$
$\vdots$
$\vdots$
$\vdots$
$\vdots$

$z z z z z z z z \quad z z z z$

$z z z z \quad z z z z$

$z z z z$

$z z z z z z z z=2 z O_{N}$

若

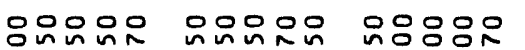

요요

- 유

융응ㅇㅁ웃

웃요뭄용

유옹요음

음용요

응융ㅇㅇ음

응용ㅇㅇㅇㅇㅡ

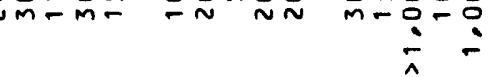

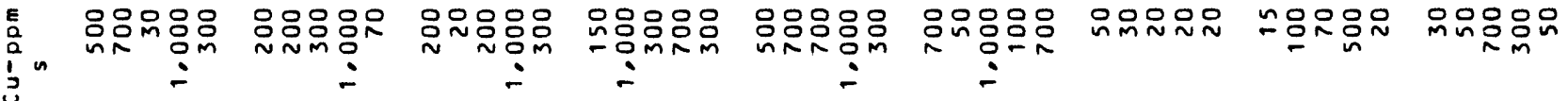

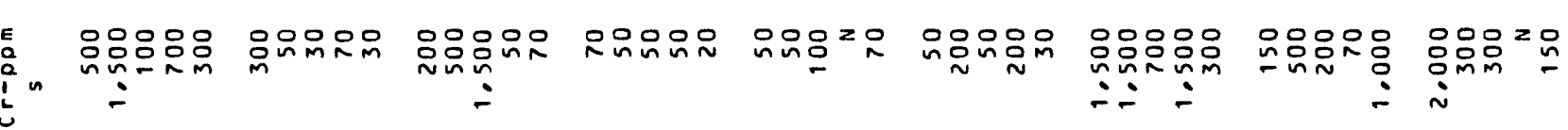

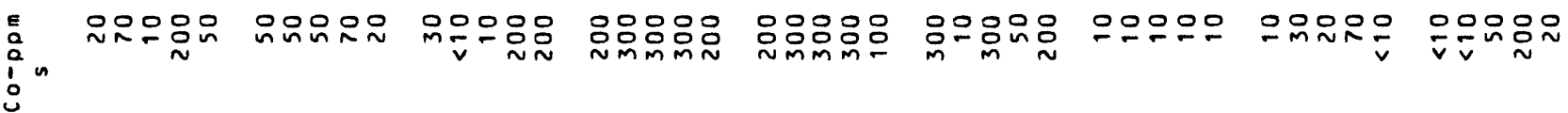

E $i^{2} n$

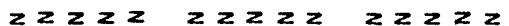

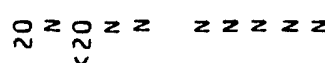

$z z z z z$

$z z z z z$

$z z 2 z z$

$z z z z z$

$\stackrel{1}{a}^{a}$

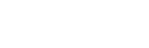

$\checkmark$

E

$\sim \sim z z \sim \sim \sim \sim \sim \sim \sim z z z \sim$

$\sim \sim \sim \sim z$

$z z z 2 N$

$z z z z z$

$z z z z z z z \tilde{v} z z z \underset{\sim}{V}$

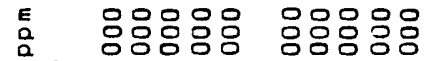

ininivin

옹응응음

nivinin

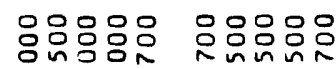

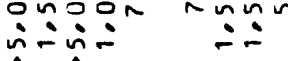

究品品品品

음옷응음옹

앗웅염음영

음음응웃

$\operatorname{innin} i n$

กヘ่

nิn

in i:

訪:

$\because \because$ in

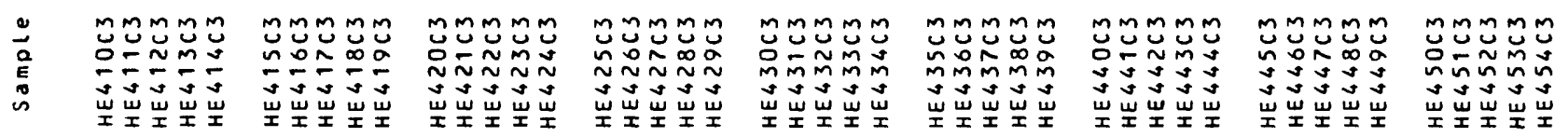




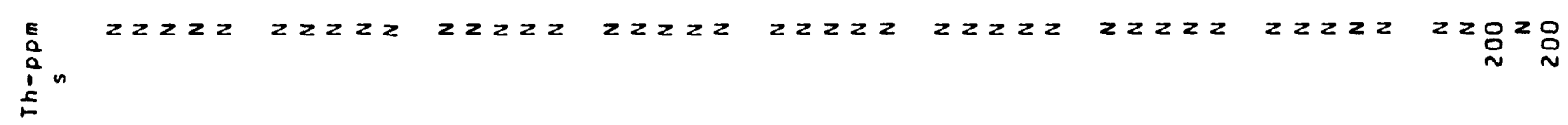




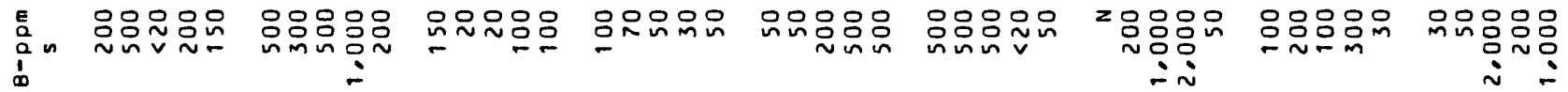

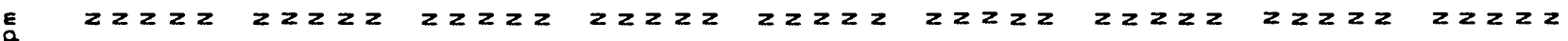
$i_{\substack{a \\ i}}^{\circ}$

E
$\vdots$
$a$

$22 z 2 z \quad 222 z 2 \quad 222 z 2$

$222222222 z$

$z \geq 2 z$ o

2 용

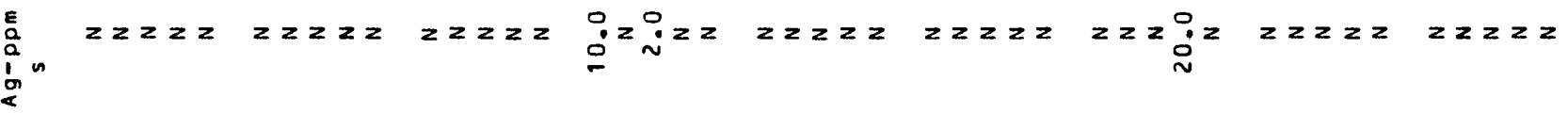

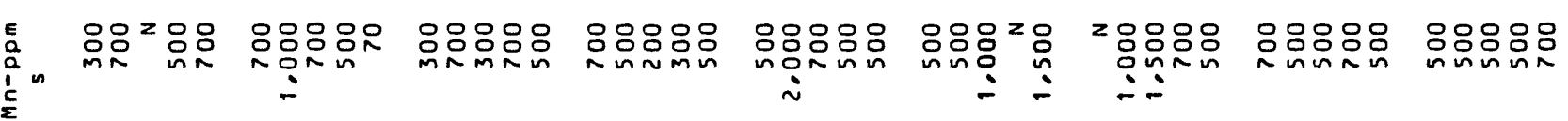

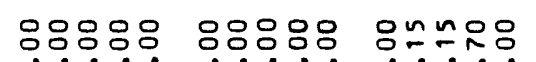

:

옹응음음

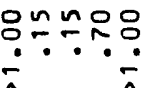

응응영응음

응응ㅇㅇㅇㅇ

응응음응

으옹응응응

응응응응응ㅇㅇㅇ응음우

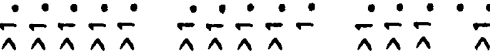

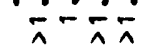

$\therefore \div \div-$

두수

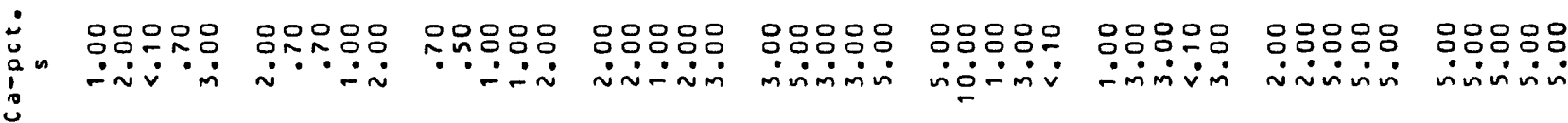

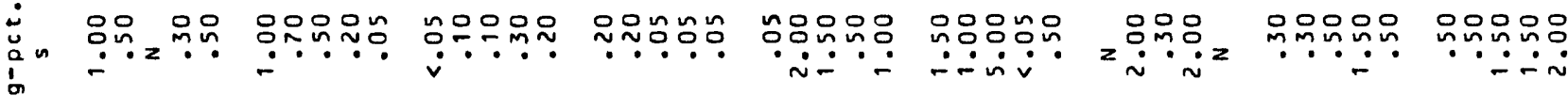

㟧 :

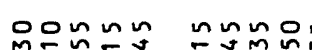

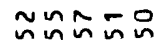

uูกơ

m은은

오능ㅇㅇㅇㅡ

은ํㅇㅇㅇㅇ

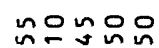

응으문

으잉

등의

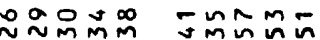

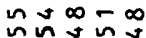

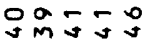

gัง

Mํํํำ

$\begin{array}{ll}a g a g & a g a g a\end{array}$

araag

araaa

adana

กヘกก

ñกn

$\sim N \sim \sim N$

$\sim \sim \sim \sim N$

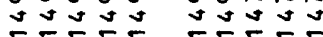

Z̃ン̃̃

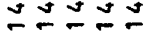

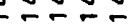

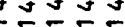

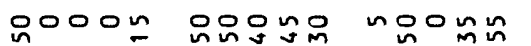

nnomo

으는ㅇㅇㅇ

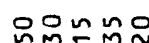

ษ⿻ำ

으은

ogngun

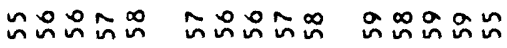

ํำนํํำผ

$m g \approx m \tilde{N}$

识兄

$\bar{m} \bar{m} \mathrm{~m} \stackrel{\infty}{\sim}$

윴ำ

$\tilde{\sim} \sim \tilde{\sim} \tilde{\sim}$

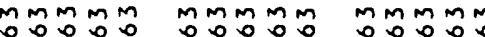

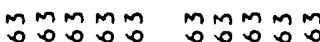

ติำ

MDMMDMm

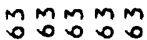

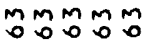

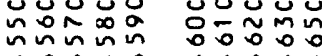

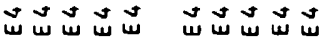

$M m M M m$

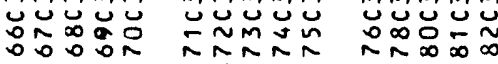

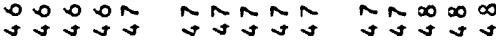

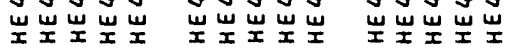

$M M M M M$ minion

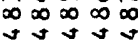

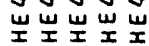

MmMmm

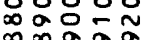

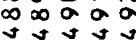

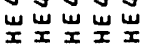

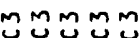
măgo

ज行

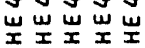

MMMMM

$\infty$ 응는 aㅇㅁㅇㅇㅁ

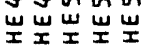




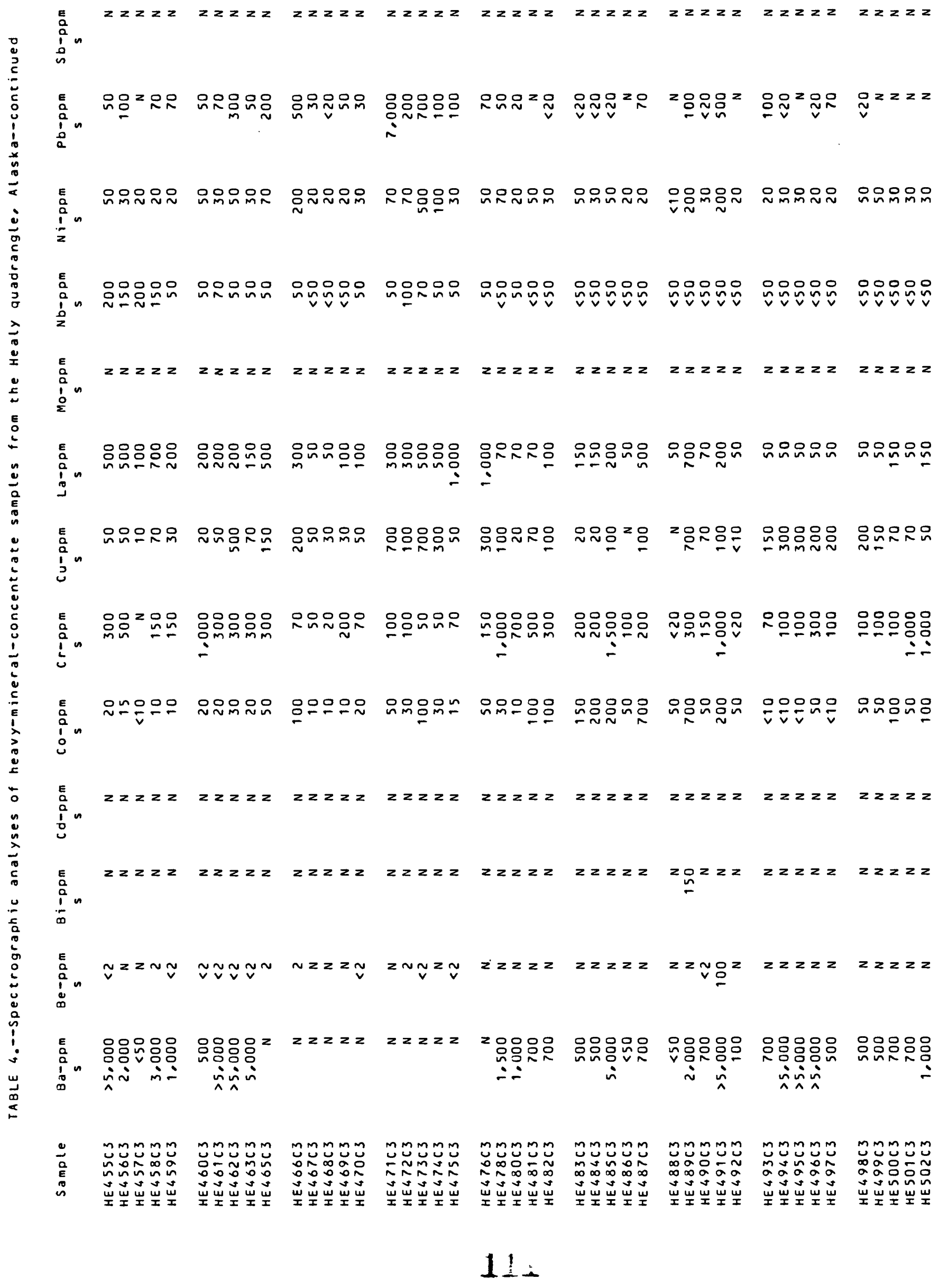




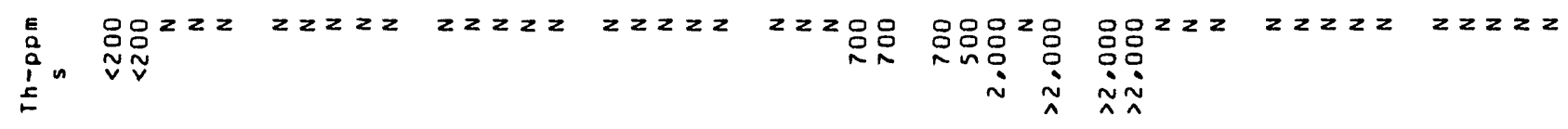

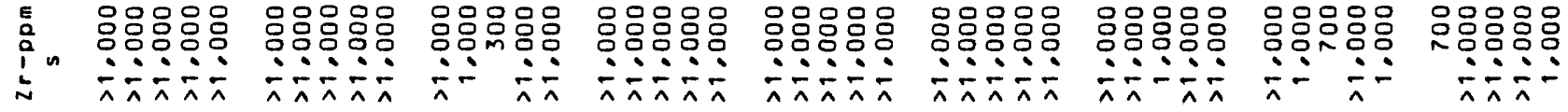

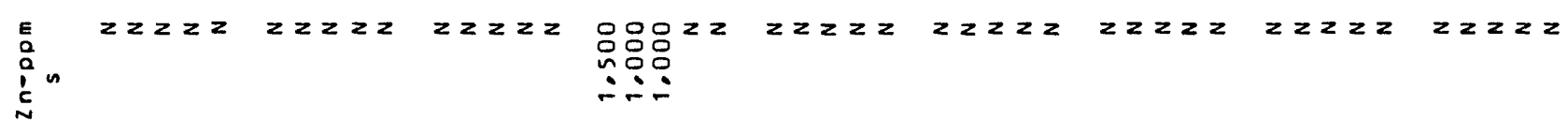

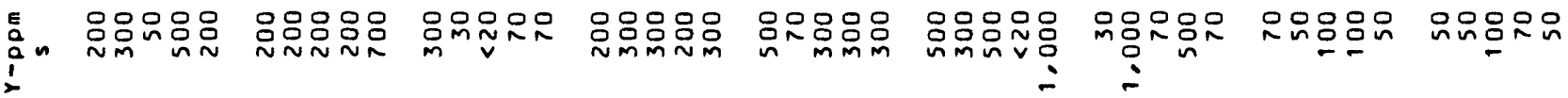

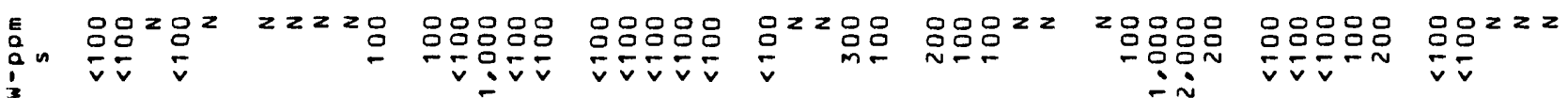

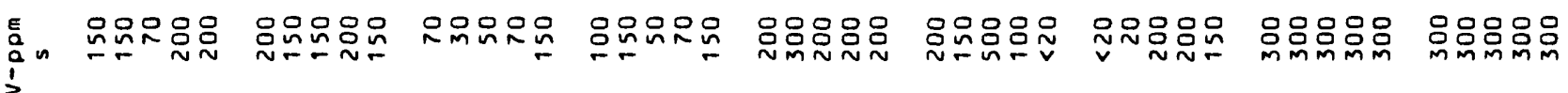

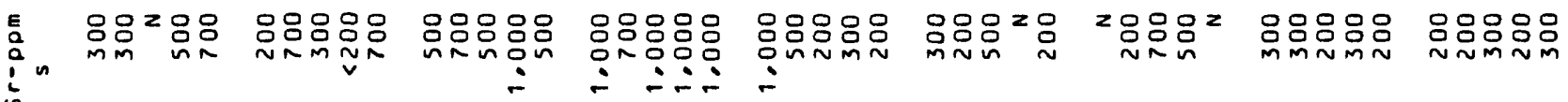

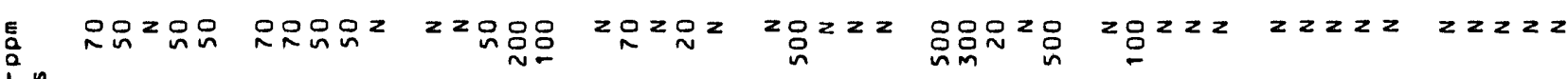
is

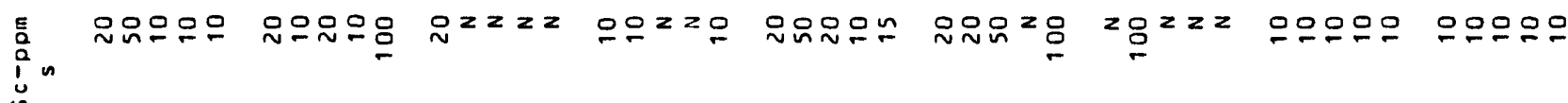

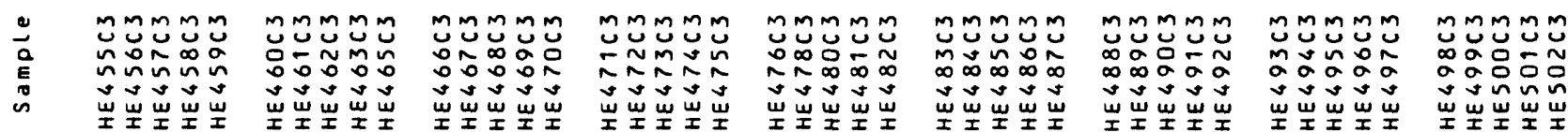




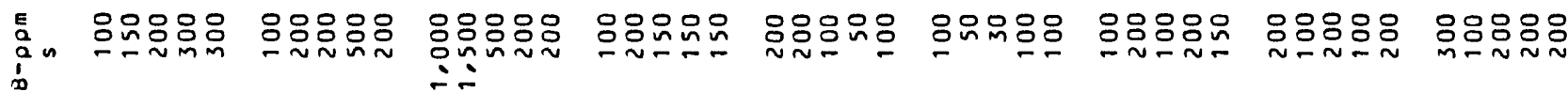

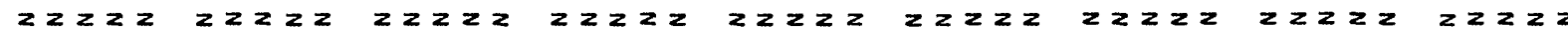
$\substack{a \\ \hdashline}_{\substack{a \\ a}}$

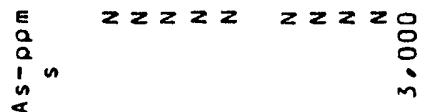

$z z z z z$

$2 z 2 z \quad 2 z 2 z 2$

$z z z z z z z z z \quad z z 2 z z$

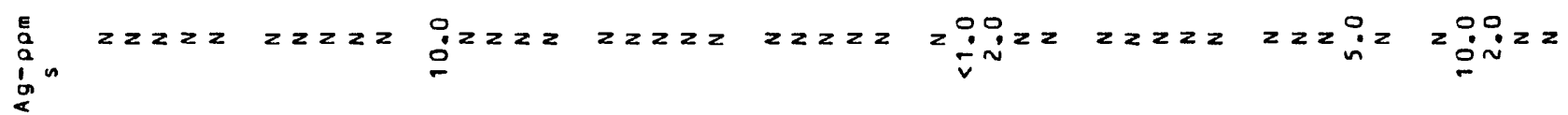

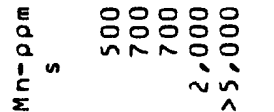

음응 욤용

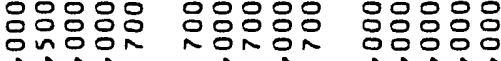

30

$\sim 2-1$

$\div$

ำi?

ㅇํㅇㅇำ

ทํำ:

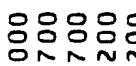

in

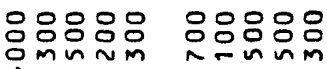

miñ m

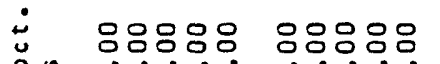

응응응

응용ㅇㅇㅇ

옹ㅇㅇㅇㅇㅇ

응용ㅇㅇㅇ

응응

ㅇㅇㅇㅇㅇㅇ ㅇㅇㅇㅇㅇㅇ

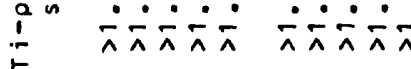

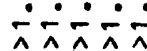

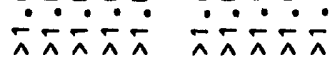

두추수

추춧

$\therefore \therefore \therefore \therefore$

$\therefore \dot{\wedge} \div \dot{1}$

$\stackrel{\dot{a}}{a}$

응영용ㅇㅇㅇㅇㅇㅇㅇ음

음용응

응요음

응ㅇㅇㅇ

용응응

영용으

응옹요 웅응요 viñón vivinisi vivinivi

imin-

min-

m. mí

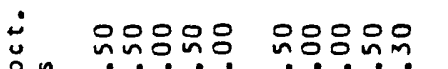

00000

$\therefore \dot{\sim} \therefore \because \because \cdots$

$\therefore \because \because$

웅요웅

옹응ㅇㅇ

용요음

政

oo웅

8

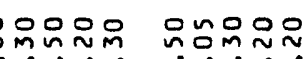
20

$-n-\dot{n}$

$\therefore \therefore \div n$

- $\dot{m-1}$

m

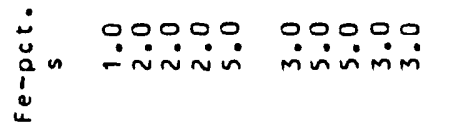

000 no

00000

00000

00000

00000

00000

00000 miñ -inimi minivi inginin

inimin

niñ oํำin

nonnu nungon ornogn

$\tilde{n}$ - 0 am amo

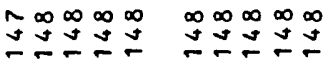

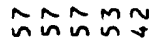

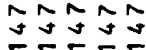

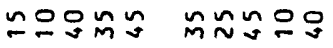

$00 M \simeq 000000$

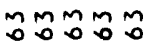

ติตับติ

$\because \simeq \approx$ ํํำ

$\Xi \simeq \cong \simeq 0$

móñ

\section{nูำ}

우 $\infty \sim a$

응으으은

응워

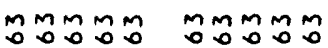

gㅇำำกำ

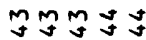

móñ

ำ

aละง

mmmmm

ํํㅇㅇํำ

ชำชูง

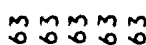

mmMmm

mmmmm

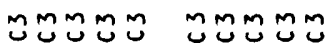

m征员

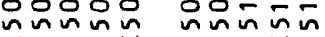

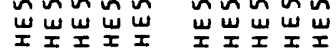

miñ

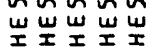

mữún
MMMmM 身证品 $\tilde{n} \sim \tilde{n} \sim \tilde{n}$

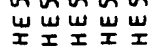

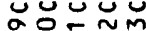

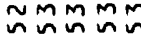
w出出出

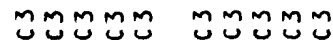

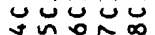

nูñññ

崩㞬㞬㞬

웅ํำ ก N $\sim$ 욤 $\infty \infty \infty \infty \infty$ ヒேンュン 


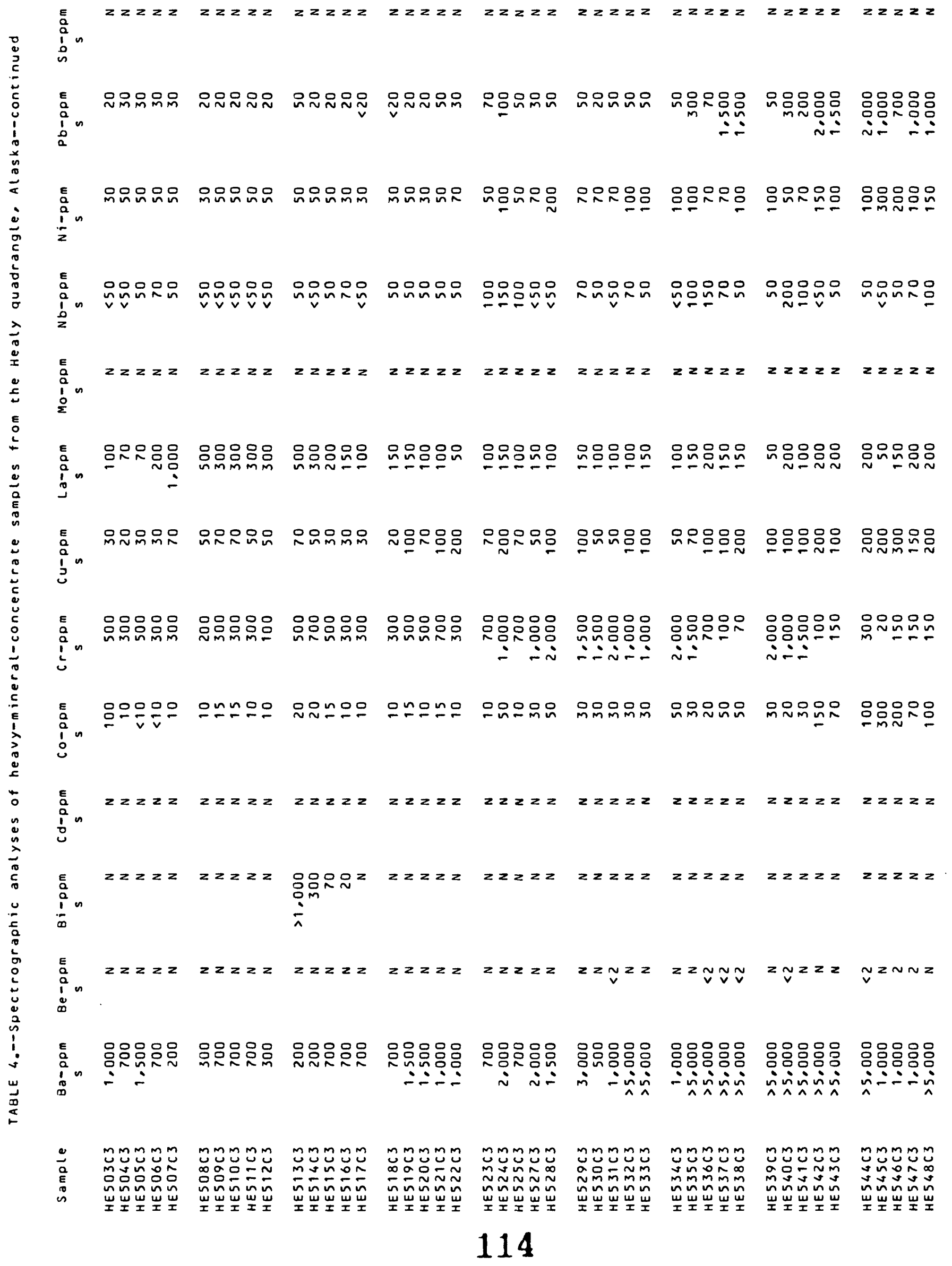




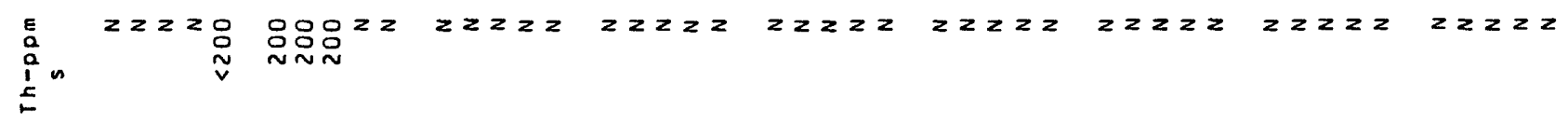

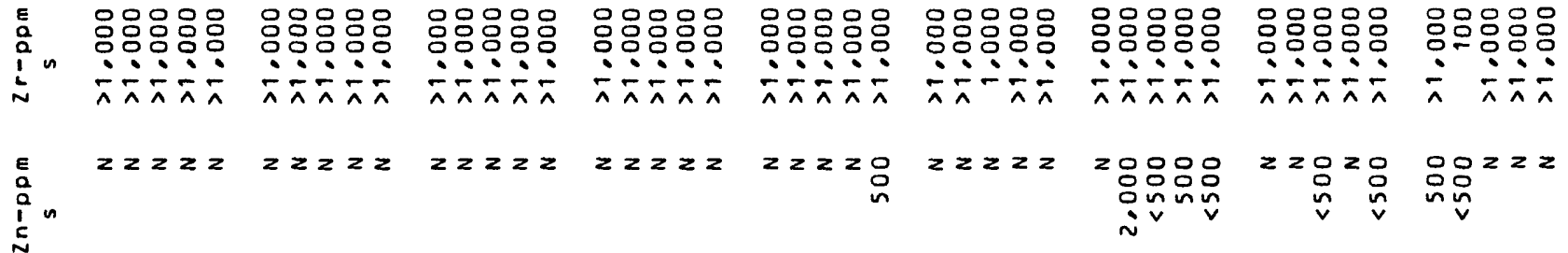

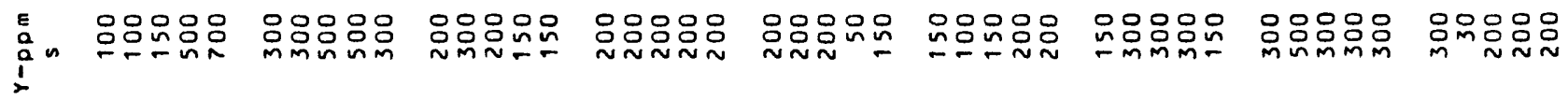

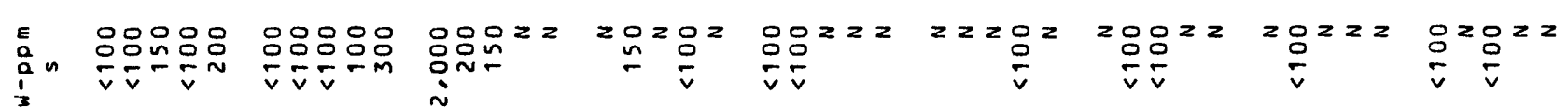

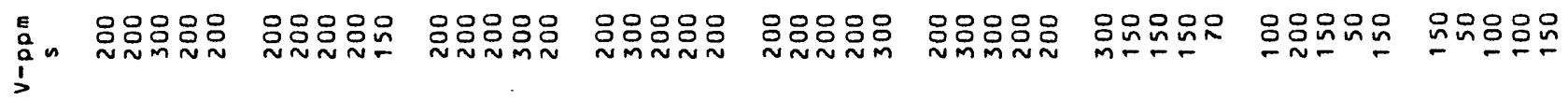

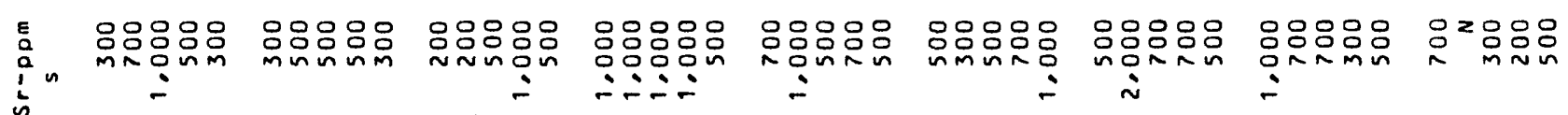

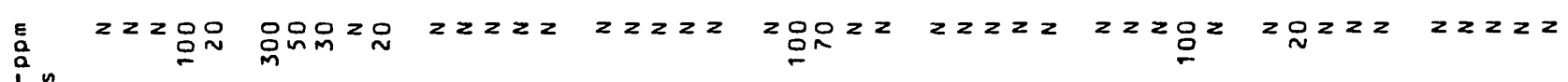
$\stackrel{1}{c}^{i}$

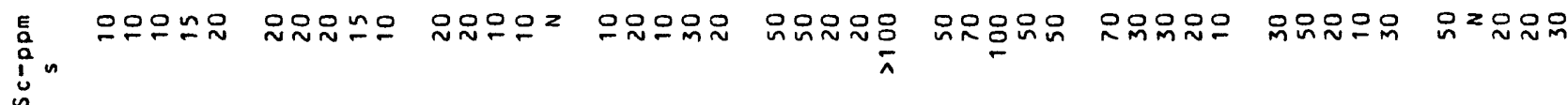




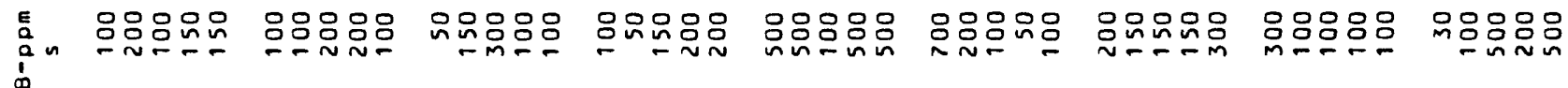

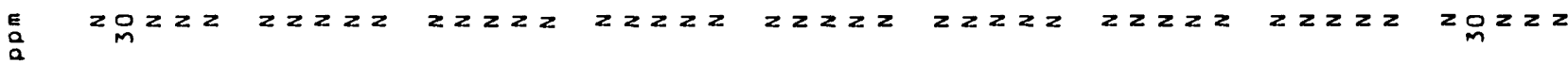
$\sum^{3}$

E

$z \geq z$

$z z z z$

$z \geq z z$

$z z$
$z$
$\vdots$

$z<z<$ 只

$z z z z z \quad z z z z z \quad z z z z$

$^{2} z=z$
$\vdots$

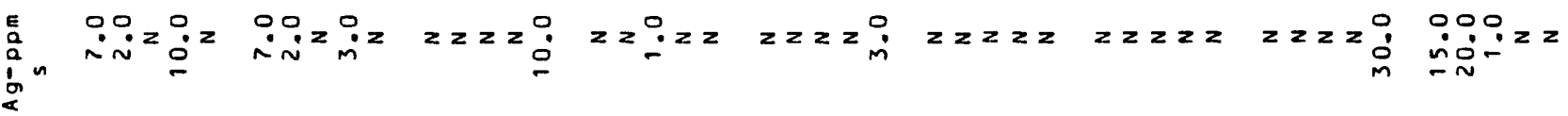

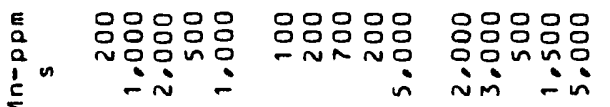

응음음운은

뭉ำ

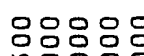

\section{응요음}

응응음응응

웅옹ㅇㅁㅇㅇㅇㅇㅁ

음옹응음음 는

애융수 연? :

- 00000

응응ㅇㅇ 웅으응

in 춧ㅊㅅ

웁음윰음

옹옹옹용용

응옹옹용

$\wedge$

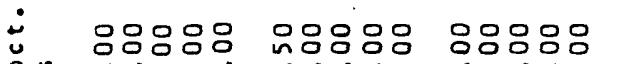

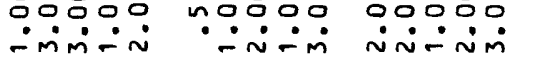

옹응요운

응응옹ㅇㅁㅇ

옹응응음

응영옹응용

응옹응응응

응응음음응

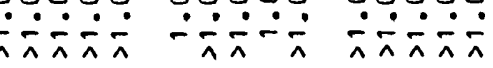

ஸேஸ்

$\therefore \div \div \div$

i

iñ

응응응응응

옹응응 응응응은

응영응응음

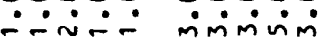

mंnivini

niminin

옹응응음

moñó

$\dot{u}_{\substack{a \\ \vdots \\ \vdots}}$

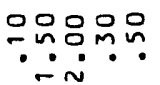

nnono

00000

0000000000

응응응응 응응융으

음음음유욤

응음음

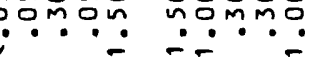

m.?ำ mํํำ

$\because \because \ddot{m} \dot{\sim} \dot{\sim} \dot{\sim}$

iñ--

mín

ú o0000

00000

0000000000

00000

00000

00000

00000

00000

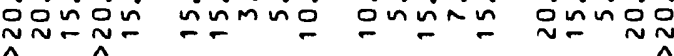

niminin

nininin

nomin

inimin

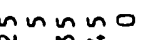

은ํํㅇำ

음ำㅁำ

요요의

monn $\min$

은으요요유

«ำㅇำ

ㅁNNㅅ

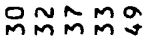

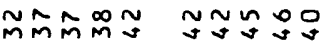

$\infty \infty \infty \infty \infty \quad \infty \infty \infty \infty \infty$

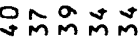

$m \sim \infty ⿻$

응요

$\infty \infty \infty \infty \infty$

$\infty \infty \infty \infty \infty$

$\infty \infty \infty \infty \infty$

$\infty \infty \infty \infty \infty$

$\infty \infty \infty \infty \infty$

$\infty$
$\infty$
$\infty$

운으음의

ษ

$\infty \infty \infty \infty \infty$

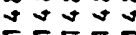

ษoํำกำ

$\simeq 0 \infty \stackrel{\sim}{\sim}$

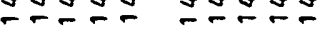

ホニンざ

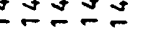

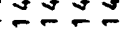

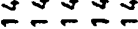

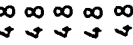

nngำ

은ㅁㅇำ

ํㅗㅇㅇㅢ

은은으움

0 n

유이응으

« n

애으요

ำง

MัM̃Mm̃

$\tilde{M} \bar{m} \tilde{m} \tilde{m}$

$\tilde{M} \tilde{N} \tilde{M} M$

กีบับํํํำ

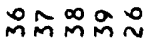

$\stackrel{\sim}{\sim} \tilde{\sim} \tilde{N}$

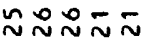

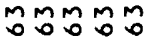

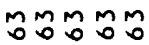

mM

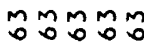

môñ

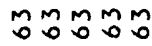

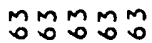

Mommon

momm

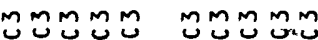

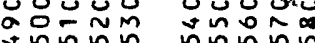

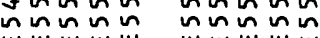

mmmmm

a $00 \mathrm{~N}$

nิธกำํำ

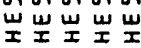

MMMmM

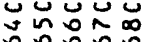

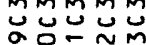

nกำ

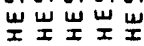

$M M M M M$

O

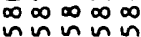

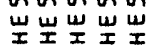

MMMMM

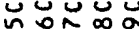
$\infty \infty \infty \infty \infty$

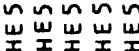

MMMMM

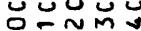

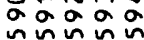

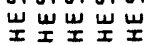




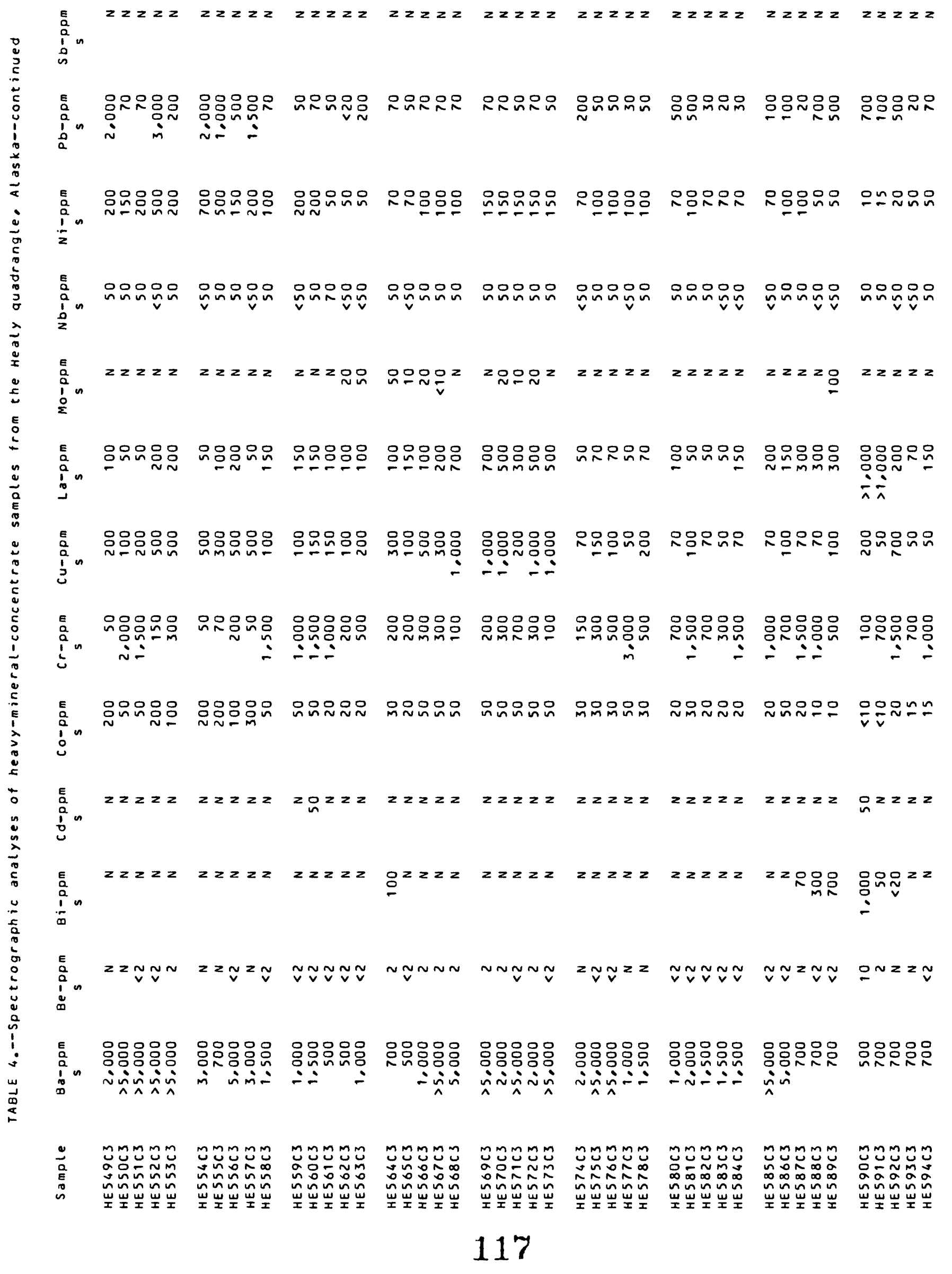




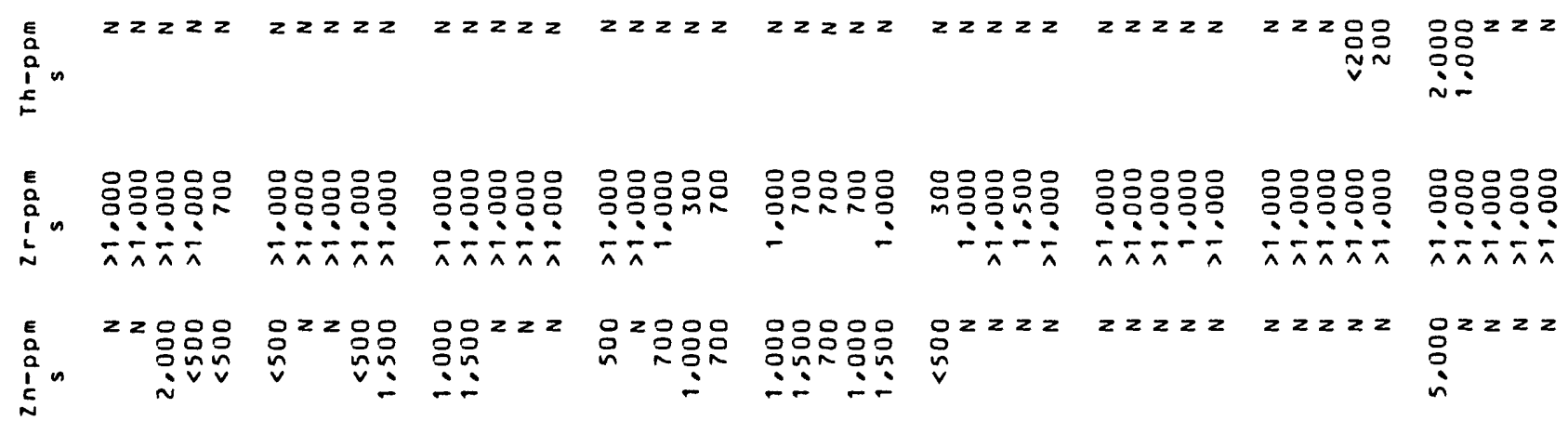

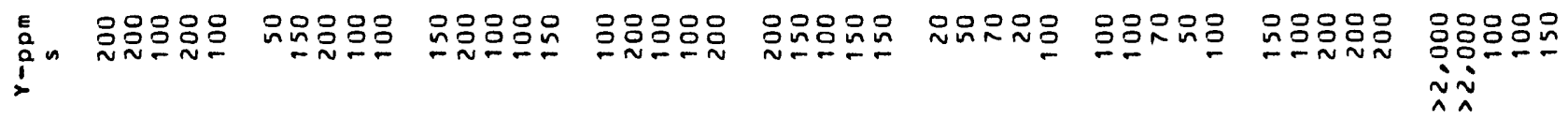

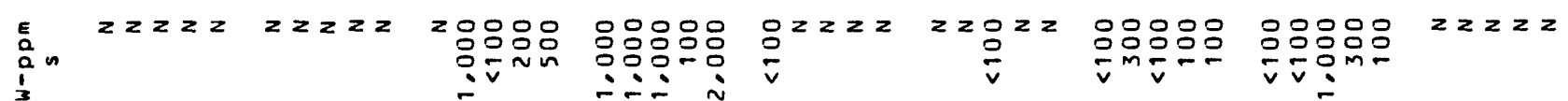

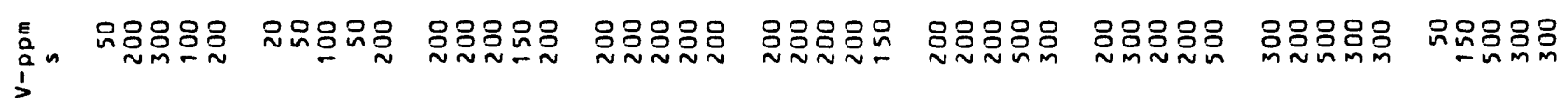

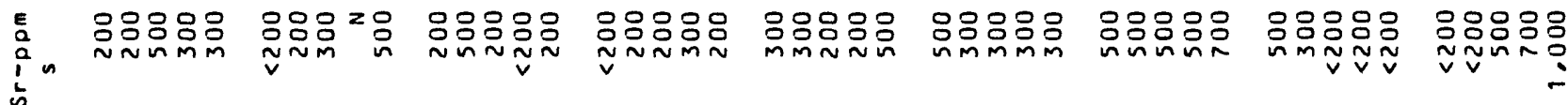

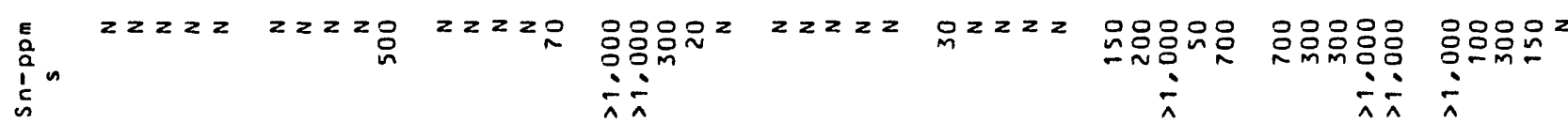

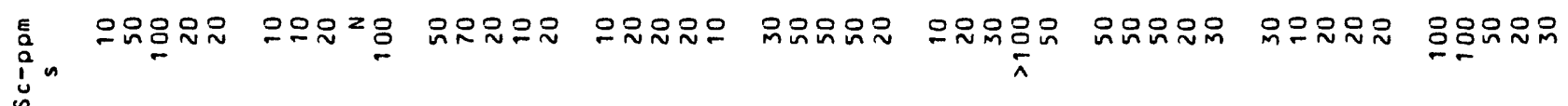

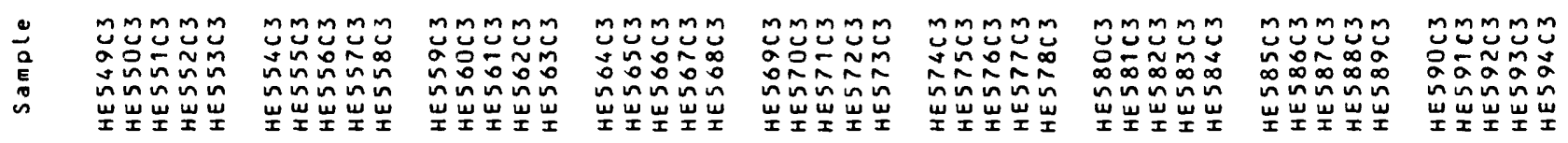




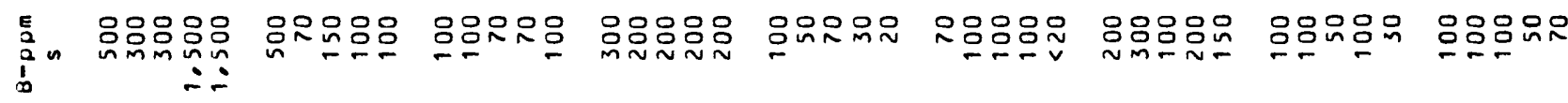

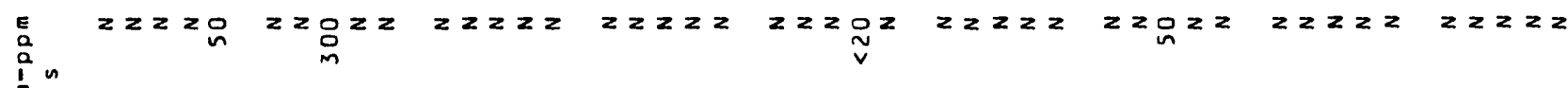

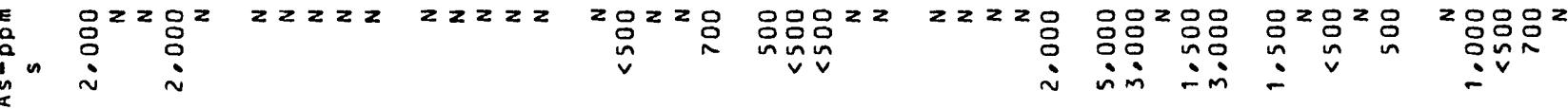

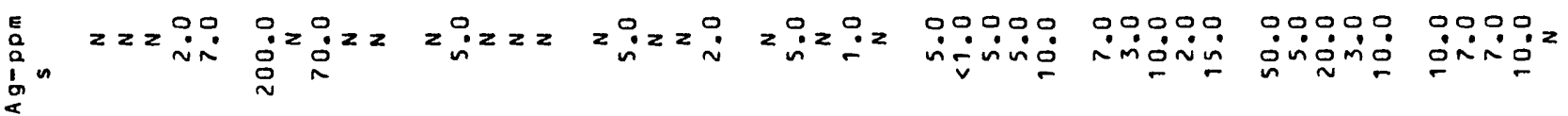

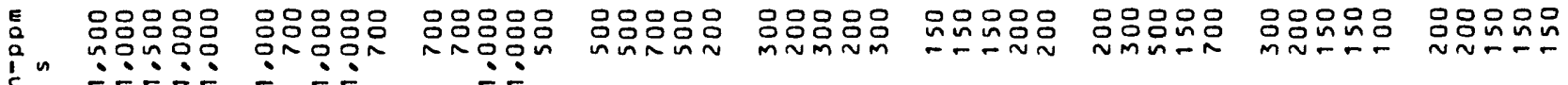

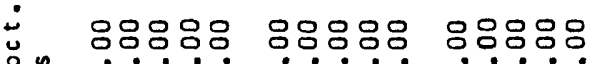
음응응응 응응응응응영요

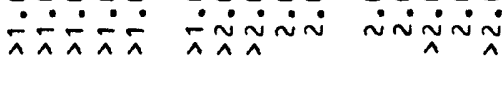
$\ddot{\sim} \sim \dot{\sim} \sim \dot{\sim}$ $\dot{\sim} \sim \dot{\wedge} \sim$ $\dot{\sim} \dot{\sim} \dot{\sim}$

은응응응응 옹응응응

옹응음응 $i$

응응응응응 응응응응

응응응응응

00000 $\sim \sim \wedge \sim$

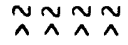
$\because \underset{\wedge}{\sim} \sim \dot{\wedge}$ $\dot{\sim} \dot{\sim} \dot{\sim} \dot{\sim} \dot{\sim}$ $\dot{\sim} \sim \dot{\sim} \dot{\sim}$ roniv viño inió

.0. 0

은은요음음

옹요음욤

은응응옹응

응응응은

옹응응응응 mimin vini- -im-in

范保

음응응응 응응영응 ․․․․ㅇำ inini

웅ㅇㅇ응

드- $\because \dot{-} \therefore$

ํํำำำ

웅ㅇㅁ웅

\section{约}

오ํ옹무

\section{ก}

옹ㅇㅇㅇ응

으은

운ำ무음

范

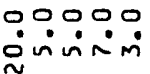

00000 염웅

00000 !

nonnn

- on nng

$\sim \infty \infty m \infty$

$\because \infty \stackrel{\infty}{\sim} \stackrel{m}{\sim}$

no

งตำ

mํำ

$\because \infty 00$ 品

บี $\sim \infty 0$

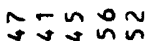

잉요

$\infty \infty \infty \infty \infty$

- $\ln n$

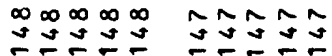

$\sim \sim \sim n N$

$00 \infty \infty ⿻$

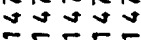

00 in 0 in

ํํํำงัญณ

ヘกヘก

ษะะษะ

$\infty \infty \infty \infty \infty$

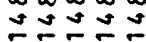

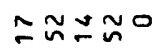

งับำ

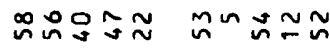

ตินกำ

gog g g

mŏ

monmon

뜽음ำ

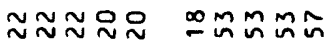

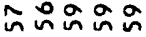

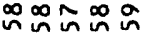

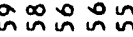

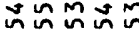

mõ

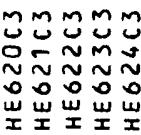

mMmmm

데요

ก N N

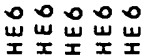

MMMMM 은

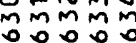

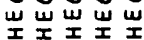

MMMmM non mmmmm

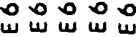




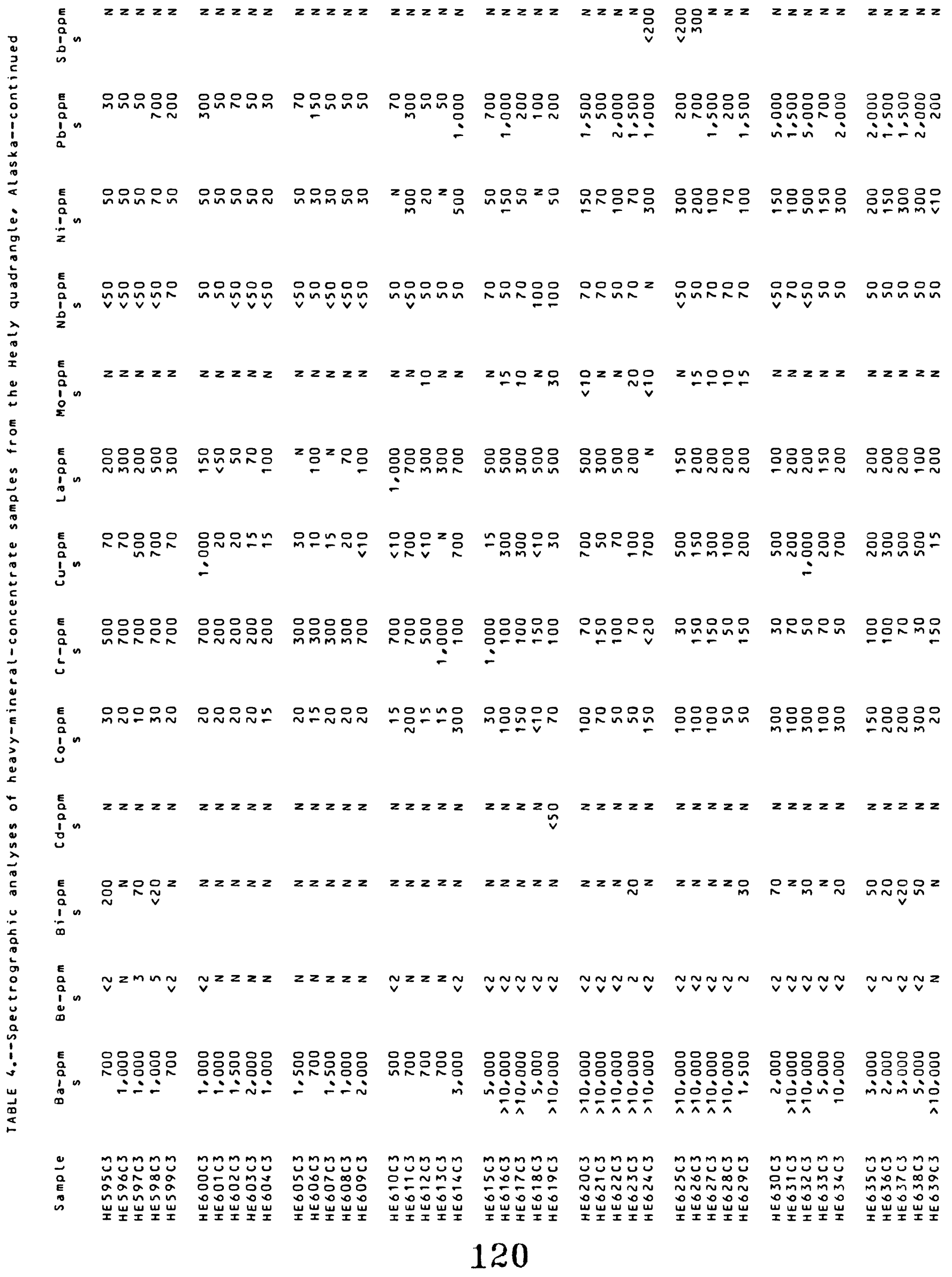




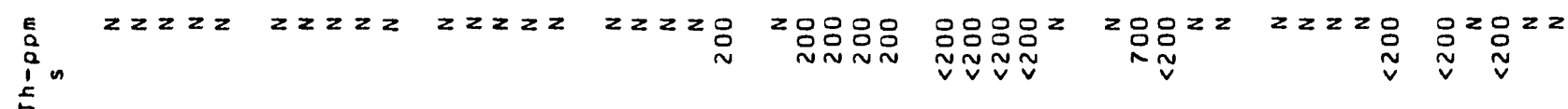

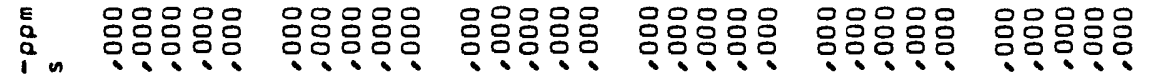

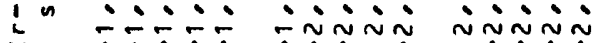

$\begin{array}{ll}\text { E } & z z z z \\ \text { a } & \\ \text { inn } & \\ \text { ch } & \end{array}$

ini $i \dot{n}$

$\sim \sim \sim \sim i n$

inini

옹응응융응용

몽

$\sim \sim \sim \sim \sim ⿻$

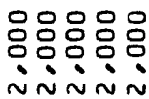

응옹응응응

$\wedge \wedge \wedge \wedge$

$z \geq z \geq 0$

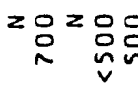

$0^{2} 20$
$0^{\circ}$ 응

$z z z z 2$

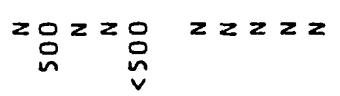

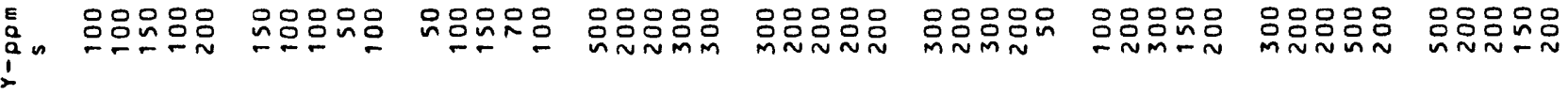

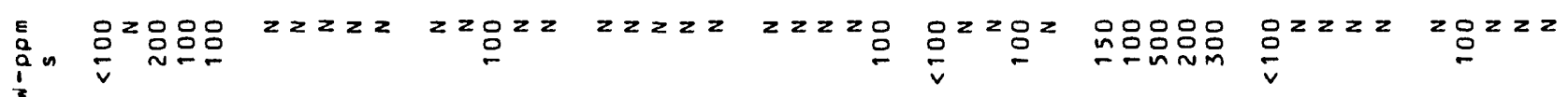

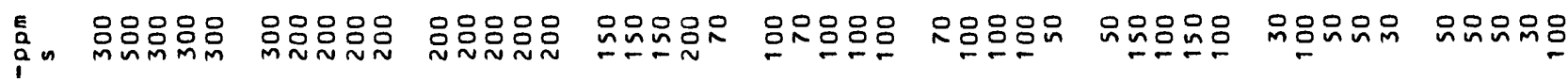

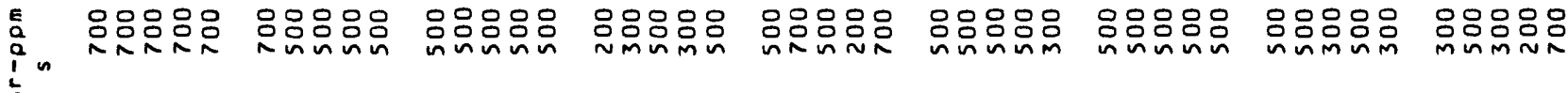

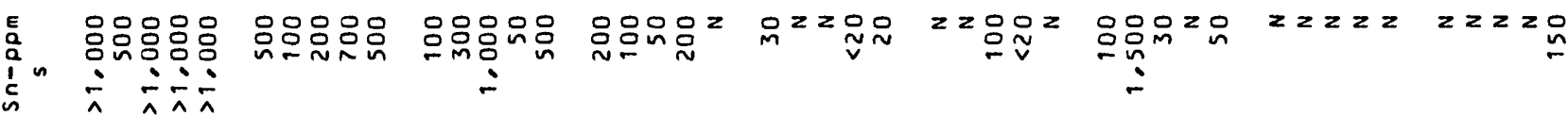

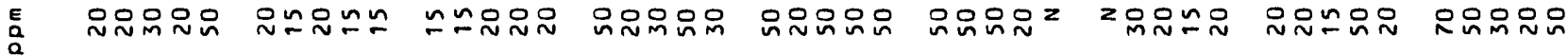
i

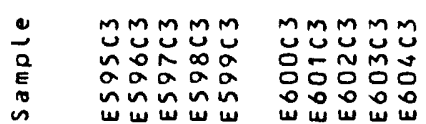

MMMmM

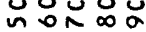

mMMmm

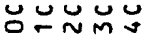

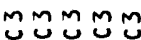

ทับํํㅇํำ

MMmmm

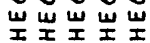

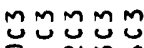
MẼ $\tilde{M} M$

00000 뽀ㅍㅣㅗ 


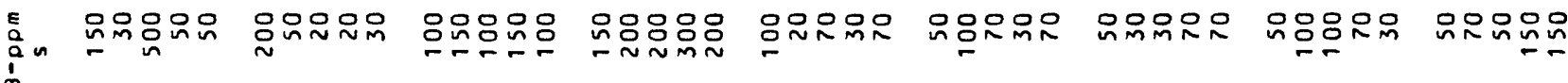

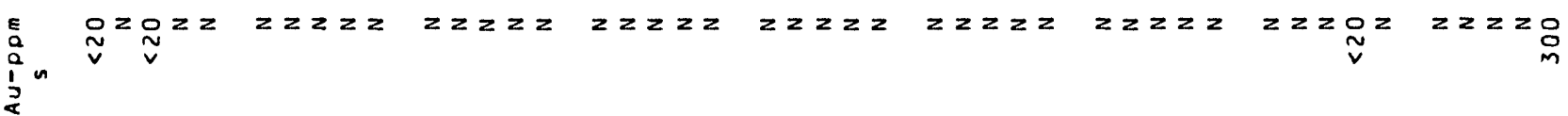

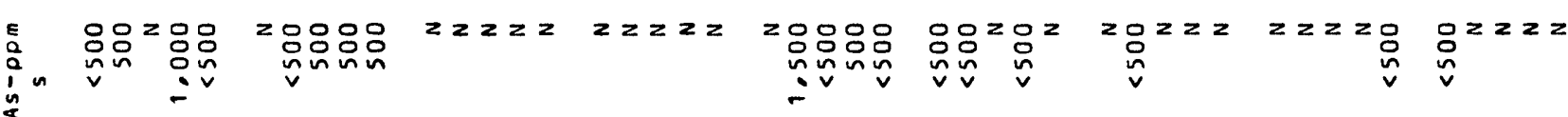
I

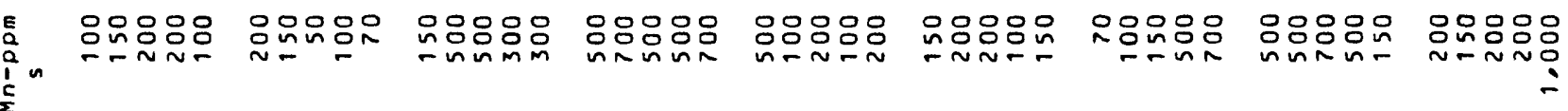

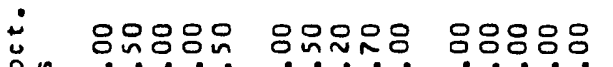

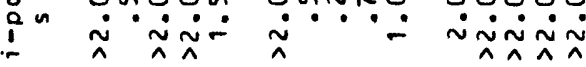

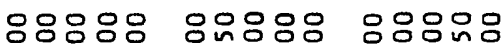
옹유앵ㅇㅇㅇ 응응응음 응응응ㅇㅇㅇ $\tilde{\sim} \sim \dot{\sim} \sim \dot{\sim}$ $\dot{\sim} \sim \dot{\sim} \sim \dot{n}$ $\dot{\sim} \dot{\sim} \dot{n}$ $\ddot{\wedge} \because \ddot{\sim} \dot{\sim} \dot{\sim} \dot{\sim} \dot{\Lambda}$ $\dot{\sim} \dot{\sim} \dot{\sim} \dot{x}$ $\dot{a}$
$\vdots$
$\vdots$
0

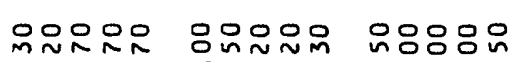

응응웅응

응웅ㅇㅁ옴은 응응웅응

엄용ㅇㅇㅇ

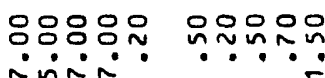
$\dot{j}$
$\vdots$
$\vdots$
$\vdots$

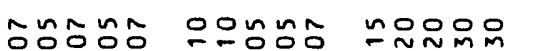

옹은은은

유은ํㅇㅇ 등응ํำ ำํํำㅇำ

응운운옹은

으용ㅇㅁ은

I

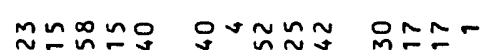

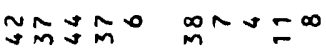
$\infty \infty \infty \infty a$ oara

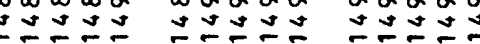

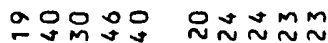
$\simeq \simeq M \simeq M$ araag

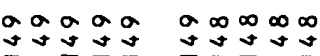

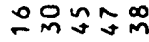

sog

o요 $\infty \infty \div N \tilde{m}$ 유유

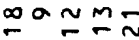

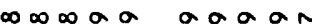
$\infty \infty \infty \infty$ $\infty \infty \infty a d$ $\operatorname{ag} 20$

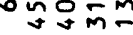
エேさンン ニேンュン

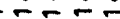

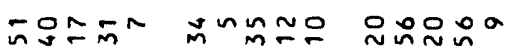

$\infty a n \sim \infty$

ㅇำ $9=0$

กะmน

momon

on $m=$

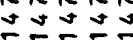

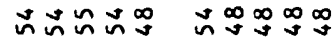

$\infty \infty a \infty$

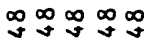

슨으는

$\bar{n} \bar{n} \tilde{n} \tilde{n}$

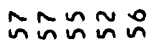

ํำ品吕会

$-\infty \sum_{m} \sim \infty$

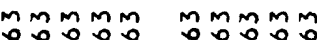

môñ

Mำ

mo. moñ

mmmmm

mommong

ํํํำนำำ

MmMmm mMmmm

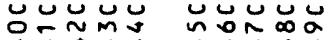

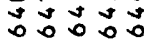

ن.

mmmmm

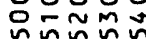

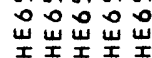

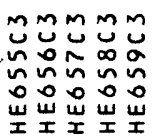

mmmmm

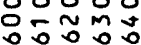

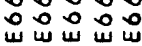

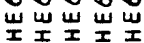

$m M m m m$ non 응응응 㞬㞬琹饪

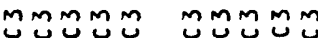
O-NMJ ñNo

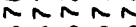

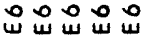

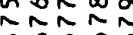

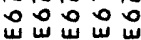
岌饪岌岌饪

$M M M M M$ $0_{-N M}$ $\infty \infty \infty \infty \infty$

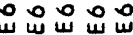




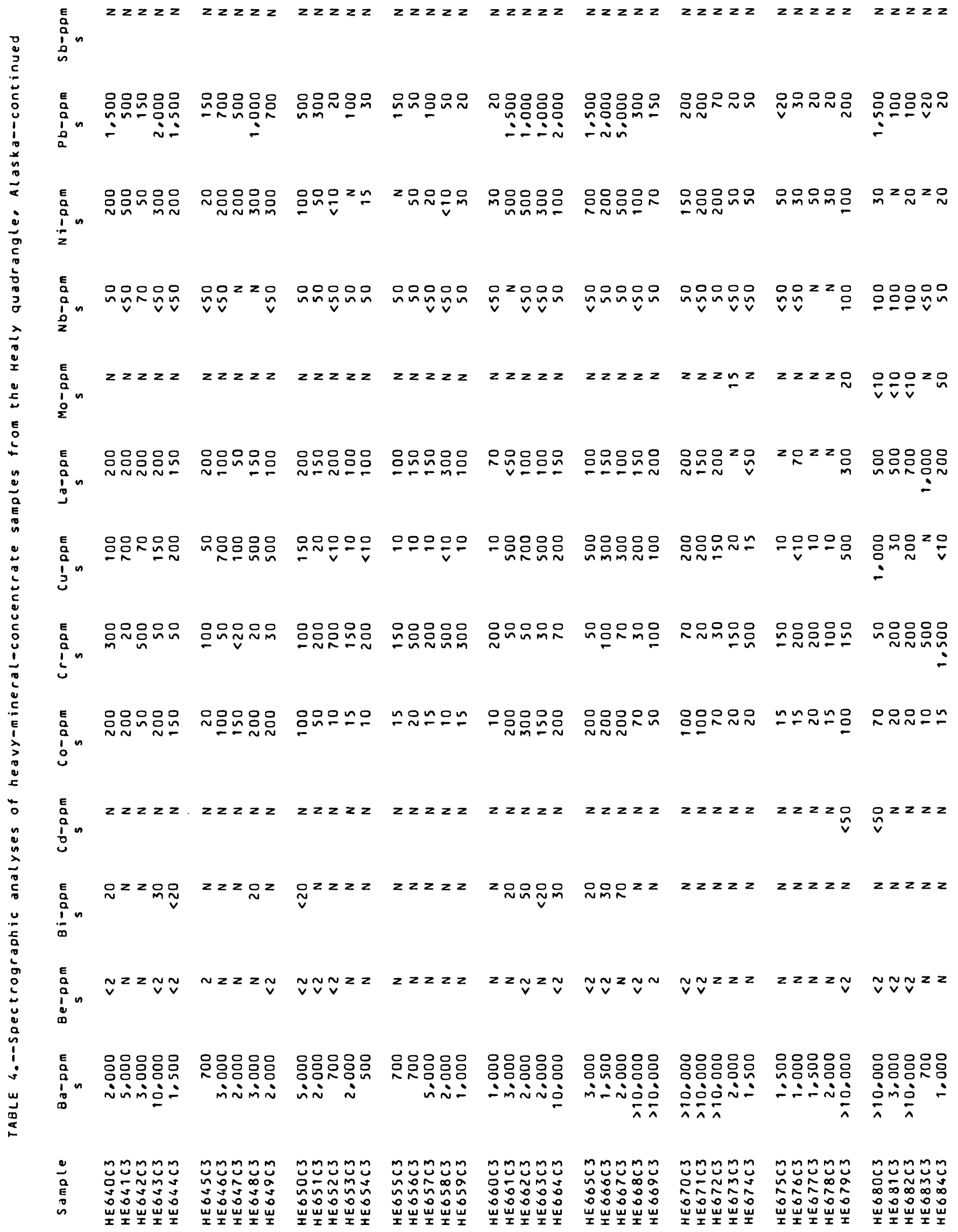




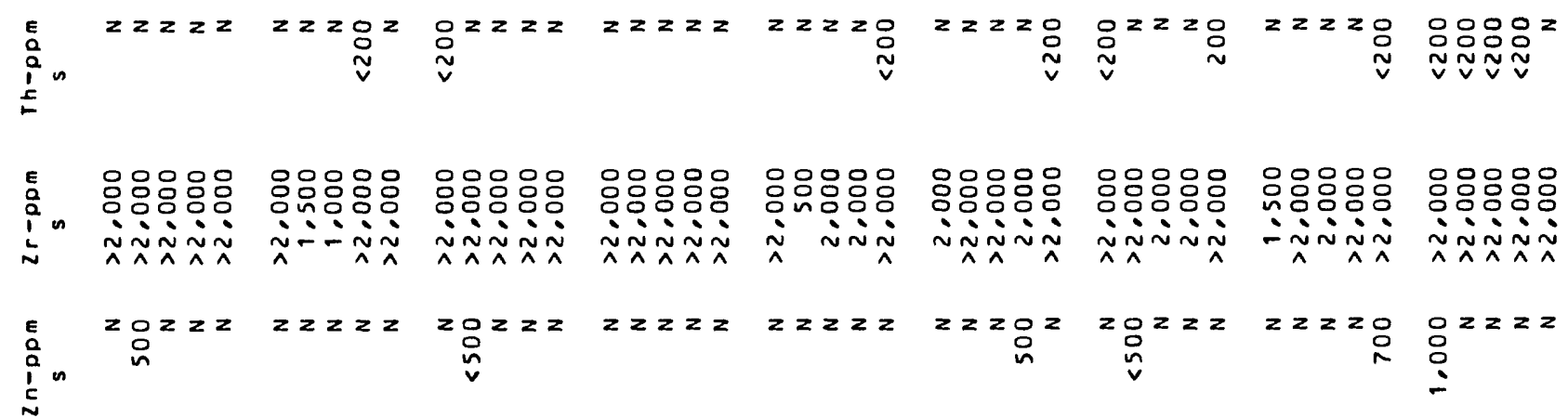

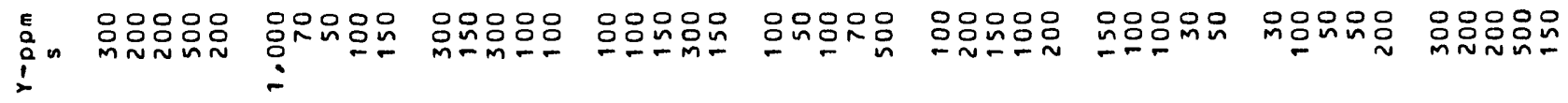

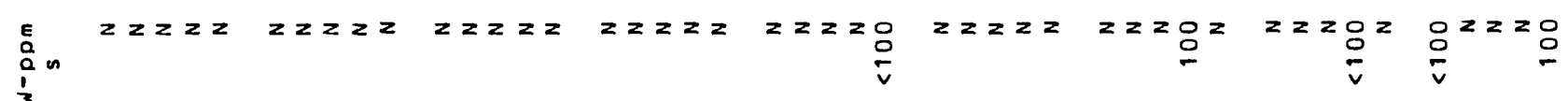

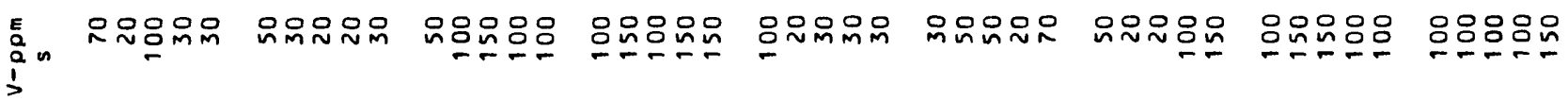

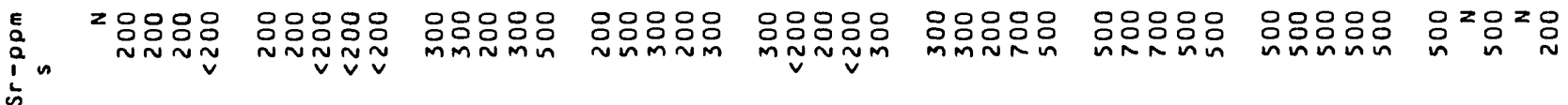

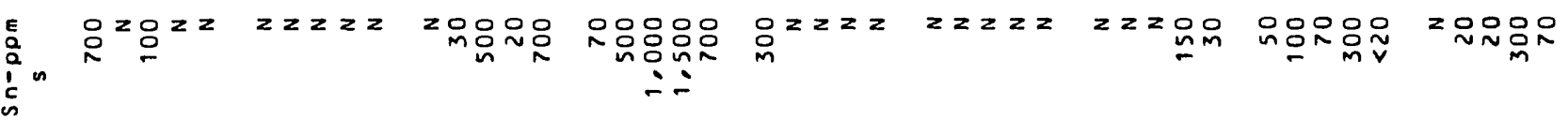

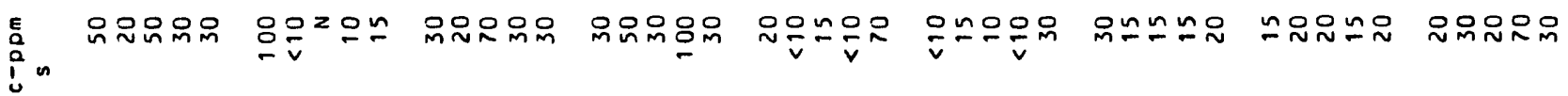

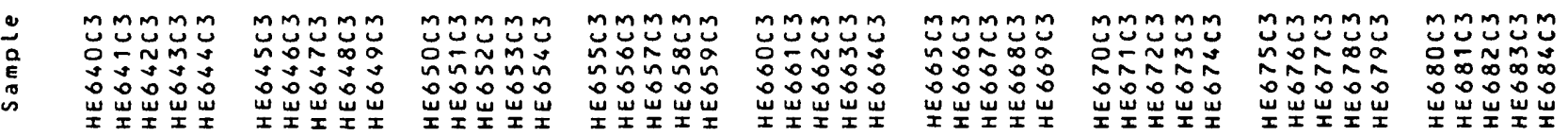




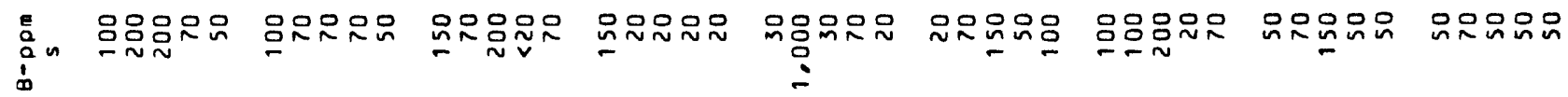

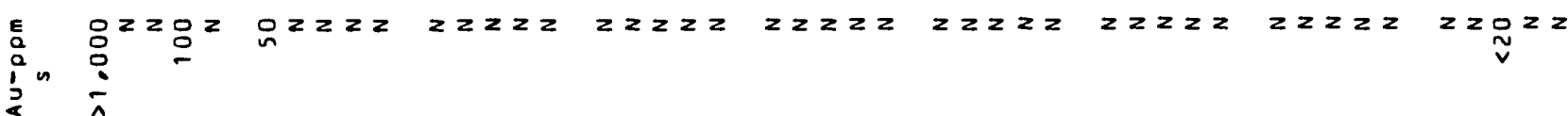

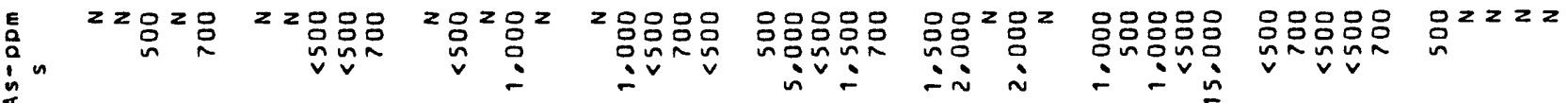
言

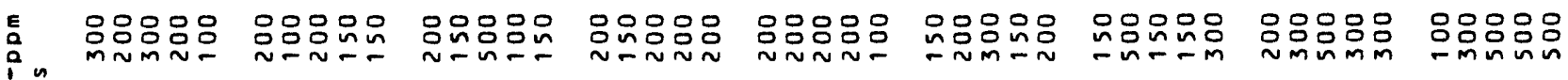

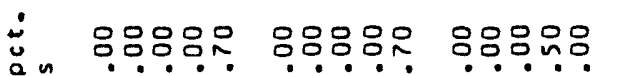
$\sim \sim \sim \sim \sim \dot{\sim}$ $\dot{\sim} \dot{\sim} \dot{\sim} \dot{\sim} \dot{\sim} \dot{\sim} \dot{\sim}$

응음윰우 웅응응응

용ㅇㅇㅇㅛ

응용유은 음음용

응음용음

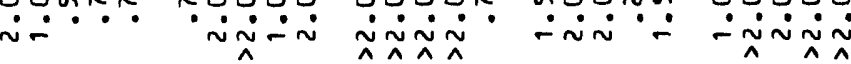
$\dot{\sim} \sim \dot{\sim} \sim \dot{\wedge}$

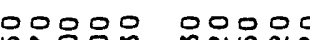
$\because \because \frac{0}{0}$ ตำำ

으욤ㅇㅇ웅

웄윤옹음 옴음웅은 융ㅇㅁㅇㅇㅇ 웅웅음

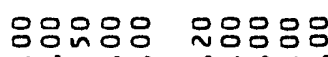
iñviv miñi 落

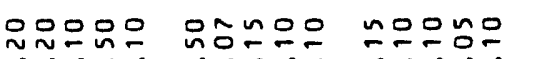

융으웅요

웄웃으웃으

능으숭응

든ํํํำ

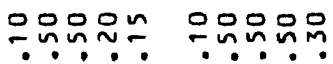

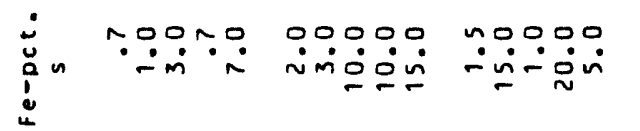

00000

00000

0000000000

000 응

on 000

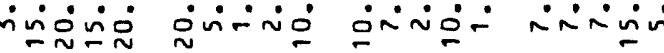

อักंน

$\because \because \because \because \div$

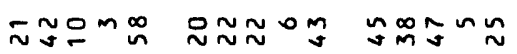

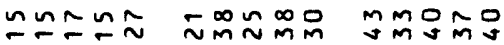

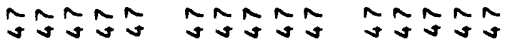

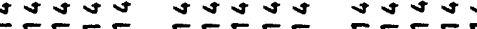

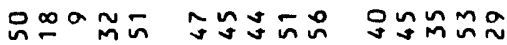

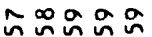
миำmo

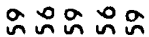

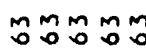

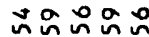

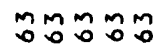

온 กิํㅜㄴㅠ ษิ์ป์ษ

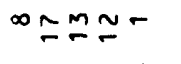
$\stackrel{\sim}{\sim} \tilde{\sim} \stackrel{\infty}{\sim}$ $\hat{\mathfrak{\Xi}} \tilde{ \pm} \tilde{ \pm}$

กันษึัง

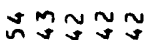

กิํํㅇำ Mำด

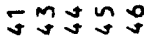

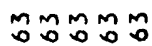
ษ ษักำก กิ์ษิ์

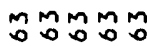

mmmmm mmmmm

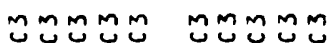

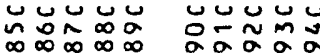
管

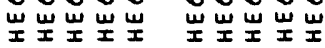

mmmmm

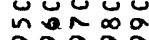

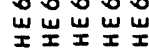

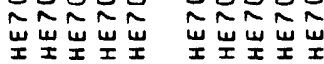

งทำง 的品的品告 mogmma

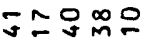
守的昌秎 mmmmm

은ำำ Mm=D舶

$\hat{y} \hat{y} \hat{a}\{\hat{a}$

SÑำก ำํำ

nNnNa

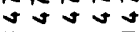
म0.000

mmmmm mmmmm

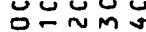
$-r-z$

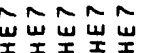

능요 テニテテこ กิกヘ 岂岂岂岂岂
MMMMM 吠兘品 $\sim \sim \sim \sim \sim ⿻$

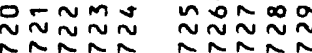

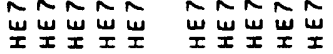



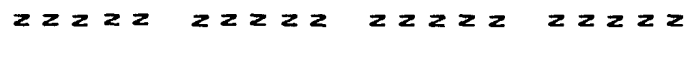

$E$
$a$
$\vdots$
$\vdots$
$a$

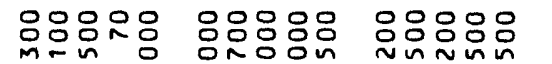

$i^{a} n$

E⿱

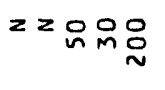

운윰용으

웃으 2 웅

웅음음은

았웅웅요

음염유유

읏윰욤용

음음은

응음으는우

ह

E
a
$\vdots$
$\vdots$
$z$

00000

n응ing

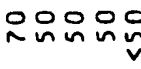

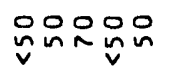

으요 $z=2$

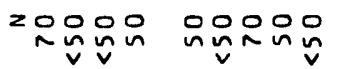

in $\operatorname{in}_{v} \operatorname{vin}^{2}$

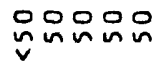

品品品品品

E

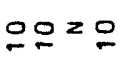

$\because \frac{0}{v} \geq 2=$

$z 2 z 2 z$

z운은운운

은은운은은

$z \geq 0 \geq 0$

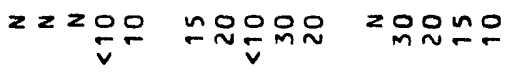

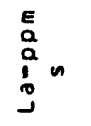

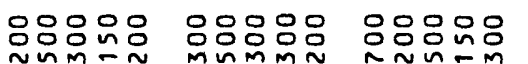

윰의

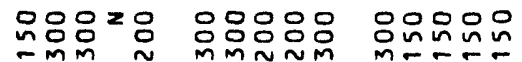

$E$
$a$
$\vdots$
$j$

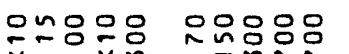

운윤웃움

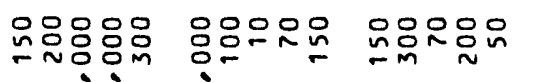

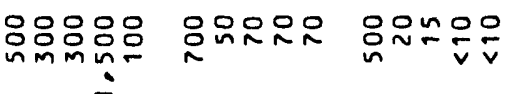

ín

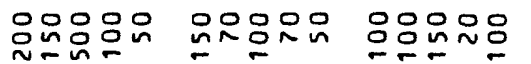

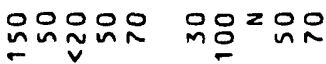

잉ㅇㅇ윰우수

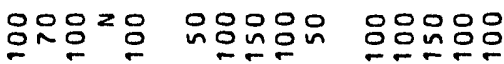

E⿱
$\vdots$
$\vdots$
$\vdots$

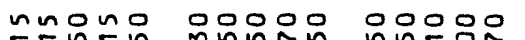

กทำ

$\min$

$\because \backsim-0^{\circ}$

유융요

oooo

oongo

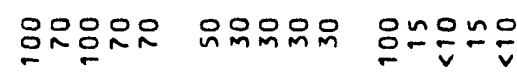

$E$
$a$
0
0
0
0

$z z z z$

$z 2 z 2$

$z z z z z$

$z z z z \quad z z z z$

$z z z z$

$z z z z$

$z z z$

$z z z z$

:

$z \geq \underset{\sim}{\sim} \geq{ }_{m}$

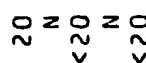

$z<z \geq 0$

$\stackrel{\sim}{v}$

$z \mathrm{O}_{\mathrm{N}} \mathrm{O}^{2}$

$z 2 z z$

$z \geq z \geq z$

$\stackrel{0}{\sim} \geq z z$

É

$z=\tilde{v} v \sim \sim \sim \mathcal{v}$

$\sim \sim \sim \sim \sim$

$\tilde{v} z z z \quad z z z \mathrm{~m}$

$\tilde{v} \sim \widetilde{v} \sim$

$\sim \sim \sim \sim \sim$

$\sim \simeq \sim z=$

$\sim z z z z$

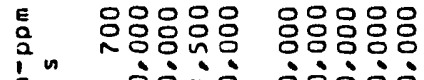

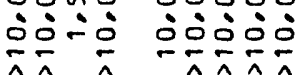

응응응응응

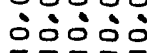

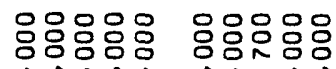

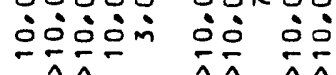

응응용응음

웅ํㅇㅁㅇ

영융유윰

iovión

옹움웅용

on:亡

응응옹용음 $\because \dot{i}=$

mMMm

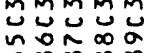

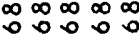

포

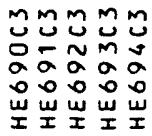

MMMㅗㅇㅛ

nindo

orñ

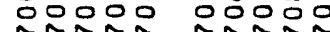

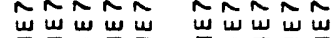

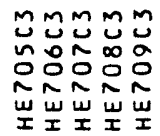

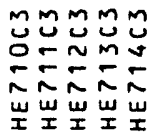

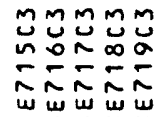

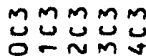

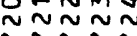
$\tilde{w} \tilde{w} \tilde{w} \tilde{w} \tilde{w}$

MmMm ñon $\sim \sim \sim \sim \sim$

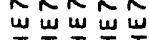




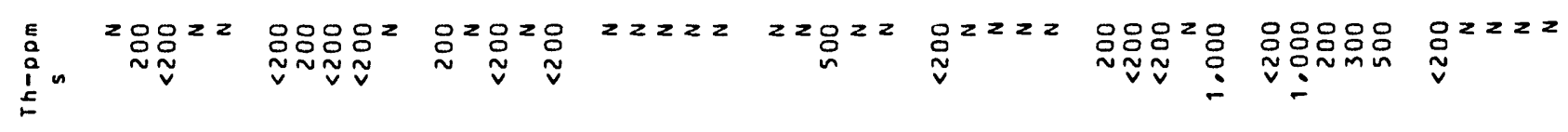

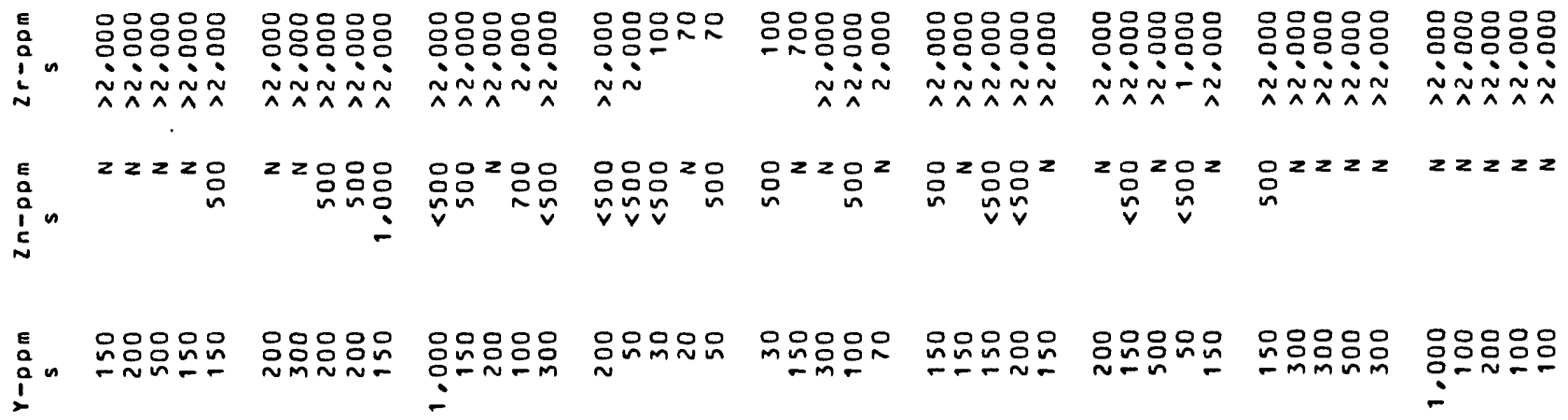

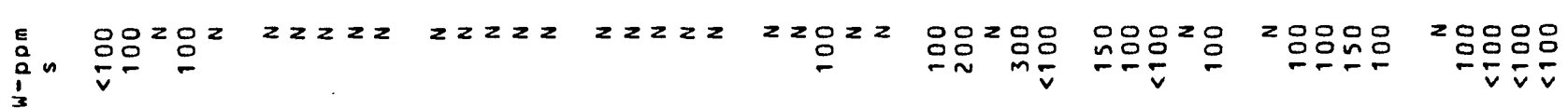

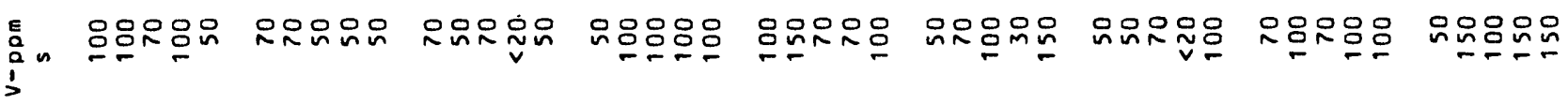

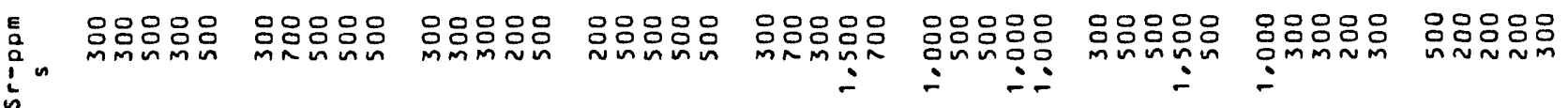

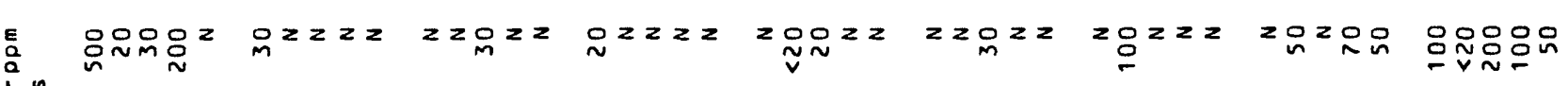
is

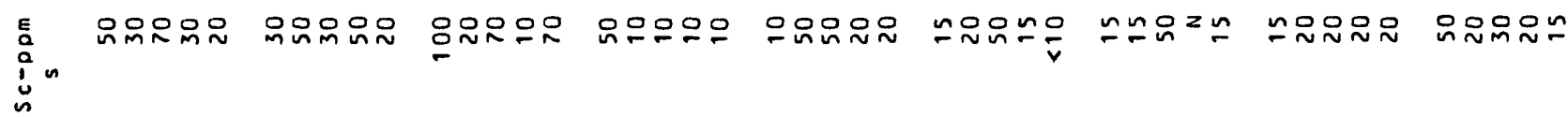

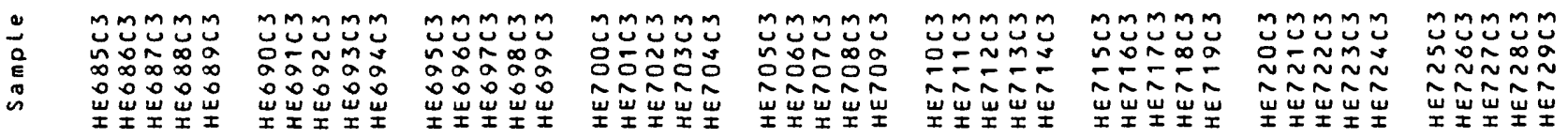




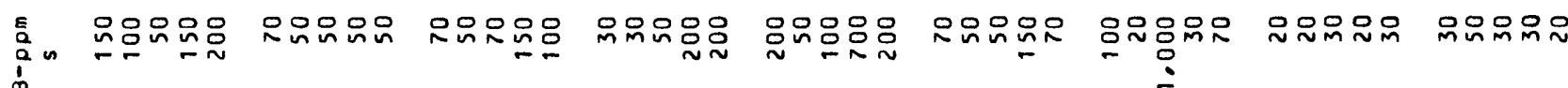

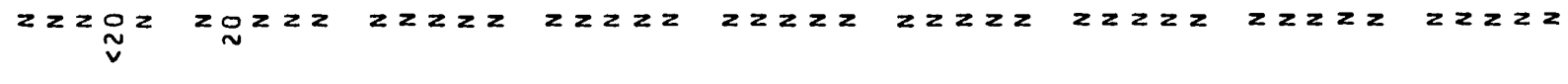
$\frac{a}{a}$

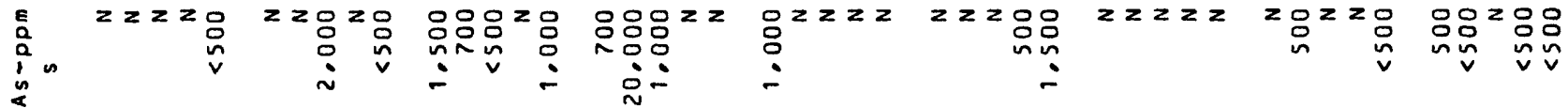

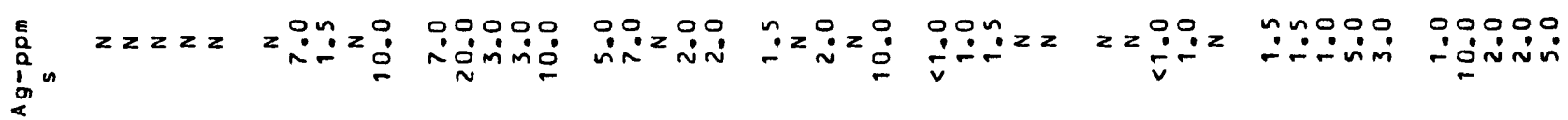

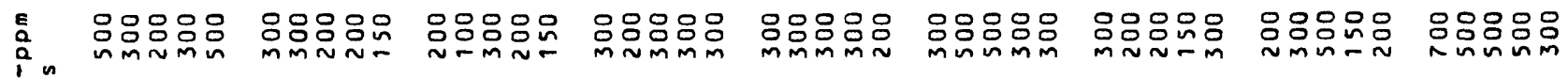
응응응응ㅇㅇㅇㅇㅇㅇㅇㅇㅇㅇㅇㅇㅇㅇㅇ 으용ㅇㅇㅇㅇㅇㅇㅛ 옹응응응응 응ㅇㅇㅇㅇㅇㅇㅇㅇ

옹ㅇㅇㅇㅇㅇ 응응응으

옹응응응 $\therefore$

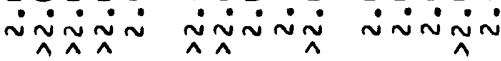
$\because \because \sim \sim \sim \dot{n}$ $\dot{\sim} \sim \dot{\sim} \sim \dot{\Lambda}$ $\ddot{-} \dot{\sim}$ $\therefore \because \div$ $\because \dot{\sim} \ddot{n} \underset{\wedge}{\sim} \dot{\sim}$

응응응응응응응은

응융ㅇㅇ응음

은응옹응

으능응응 응응응응 ininiنंmin mini $\because \therefore \dot{\sim}$ minis

응응ㅇㅇㅇㅇㅇ 은응음응 응응응응 ín" i

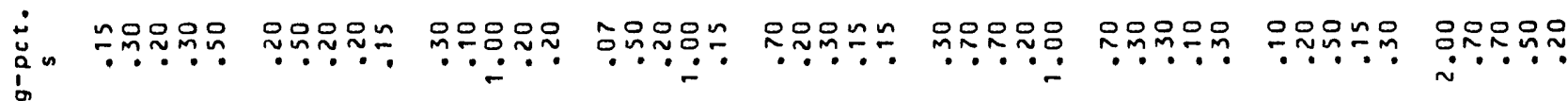
in

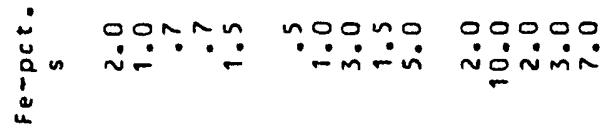

00000
0inmin

00000

nooon

$\because 0 \sim 00$

00000

00000 -

น $\therefore$ min ninmin जिi̊요

눙요

ñono

있인

morñ

웅으음음

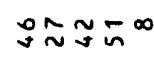

$\sim$ ํㅛ용

으는

Don

음ㅇ

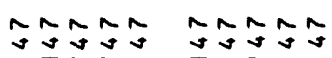

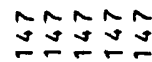

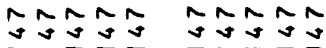

$\mathfrak{y} \approx \mathfrak{z}$

Doñg

agogm

엉요

事守的出

ปิษ

NANN

vinia vivivi

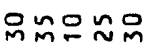

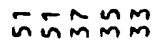

on $\sim+\infty$

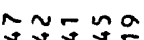

M $\stackrel{\infty}{\sim} m \stackrel{\infty}{N}$

on $m=0 m$

으ํํํำ

งูน

m은요

이옹요

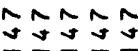

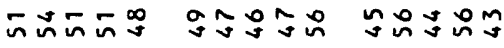

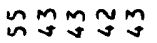

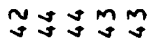

ษ⿻ำ

そูปปู่

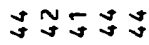

요의 $\sim$

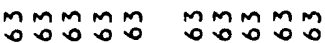

môñ

mascom

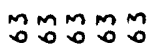

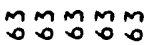

moñoñog

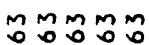

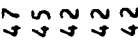

mmmm

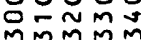

ผิํํํํำ

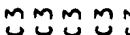

miñ

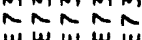

mmmmm

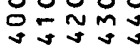

슨슨

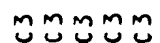

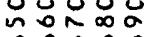

NNN

秘出出出

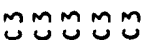

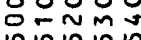
ถูก๊ำก

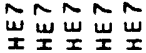

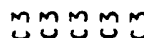

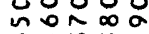

ññ

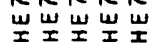

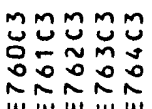

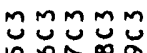

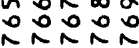

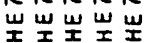

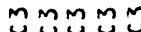

ONNM ลกลกล์

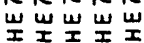




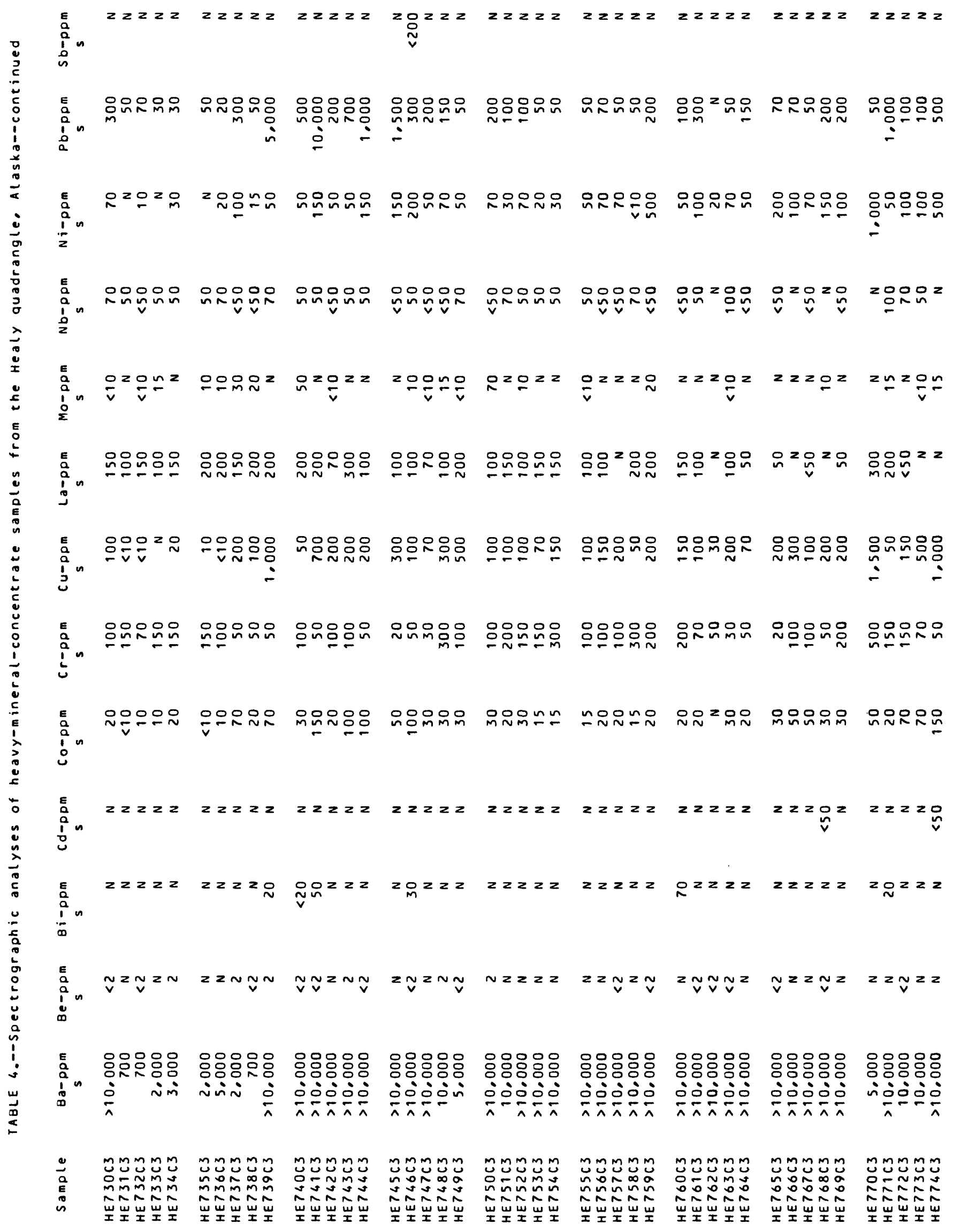




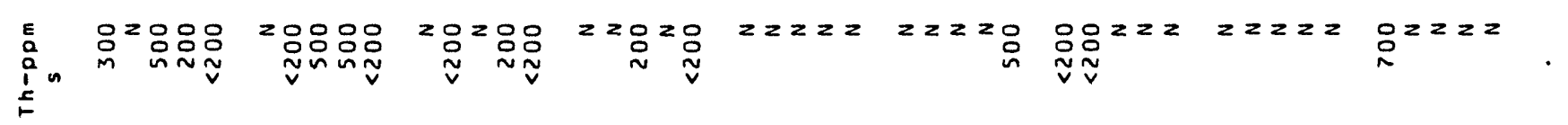

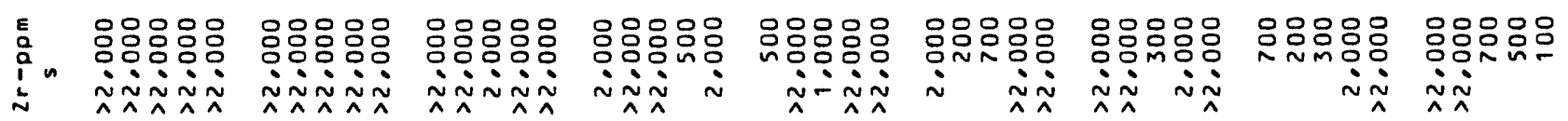

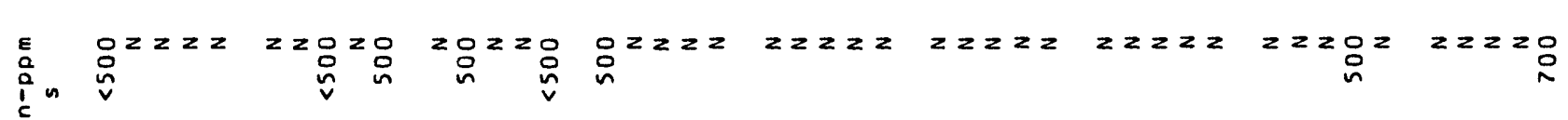

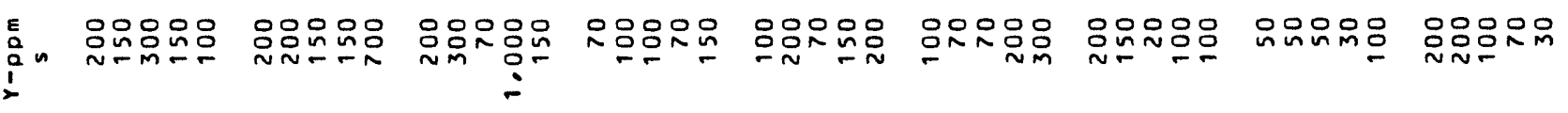

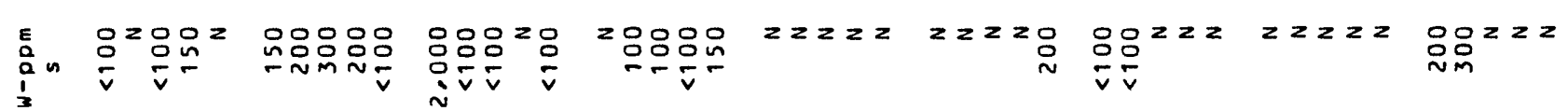

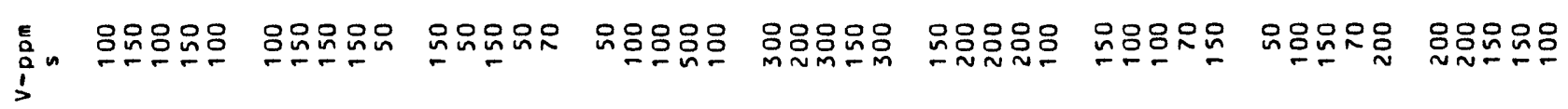

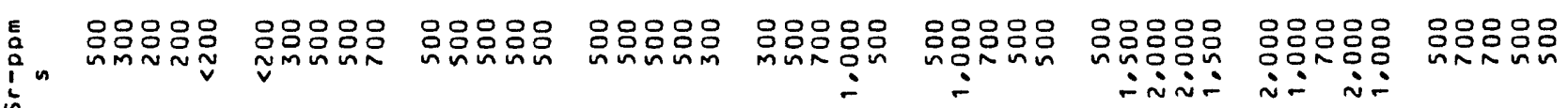

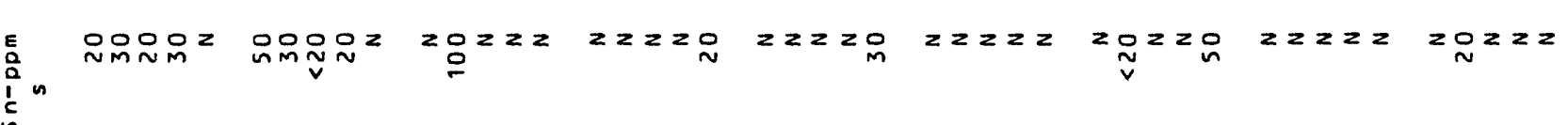

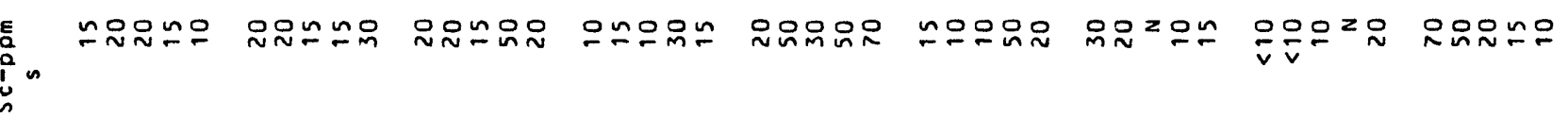

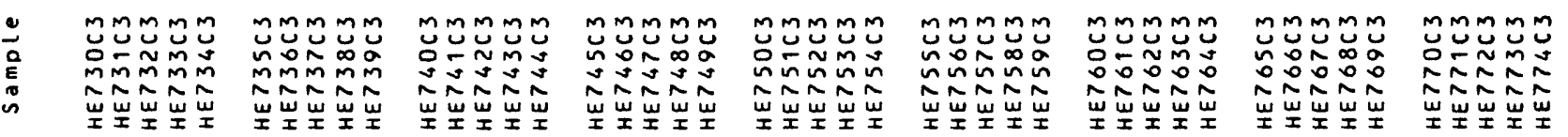




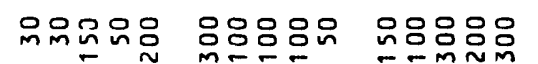

영ㅇㅇ

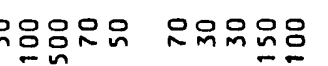

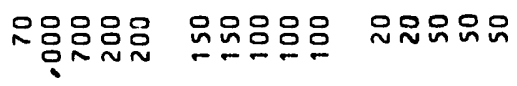

$z z z z$

$z z z z z \quad z z z z z$

$z z z z z$

$z z z z z$

$z z z z$

$z z z z$

$z$

$z=\underset{N}{V}$

$z 2 z 2 z$

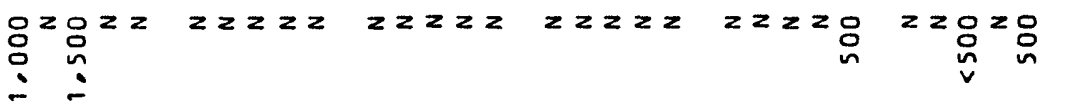

$\stackrel{9}{0}^{2}$

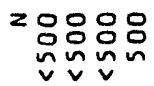

严

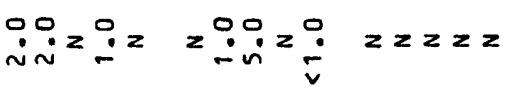

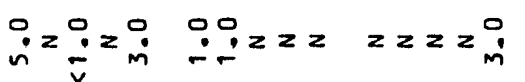

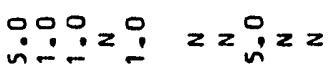

inivinim

$E$
$\frac{1}{0}$
$\frac{1}{2} n$
$\frac{c}{2}$

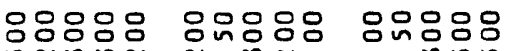

응응응웅으

욤

음운응

음ํํ윰유

옹용ㅇㅇ

응음욤요

옹응응

范n

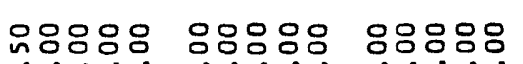

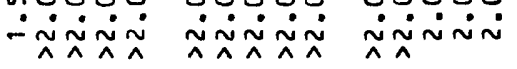

옹요음 웅용요음

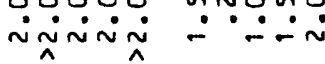

88880

응ㅇㅇㅇㅛ

$\dot{\sim} \underset{\sim}{\sim} \tilde{\wedge} \dot{\Lambda}$

$\dot{\sim} \tilde{\sim} \tilde{\sim} \dot{\Lambda}$

옹ㅇㅇㅇ음

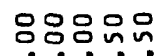

:

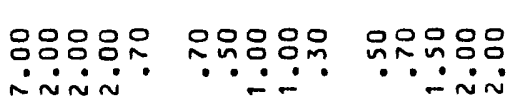

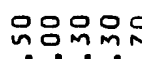

읍음용응

응응요음

응응웅응

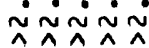

$\ddot{\wedge} \dot{x}-$

$\dot{\vdots}$
$\vdots$
$\vdots$
$\vdots$
$\Sigma$

00000

$0000 n$

nnnon

กับทักณ

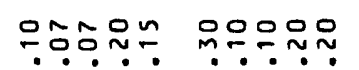

oogon

ํํำำ

$\simeq \longleftarrow$ ำ

우응ํํ유우 $\dot{m} \cdot$.

00000.00000

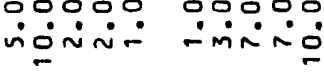

ooroo r nooo

00000.0000

$000 \because 0$

$0.00 \% 0$

00000

$\dot{m i n} \dot{m} \therefore \dot{m} \dot{\sim}$

nin்요요

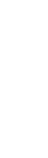

응ํํㅇ 으는

으웅의

ํำ음ำ

온ำ음

웄드워으으

웅웍으

蹒的品

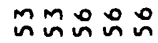

กีก๊ำน

可的昌昌赫

$\sim \sim \sim \sim \infty \infty_{\infty}^{\infty} \infty \infty \infty$

$\sin 2 \pi a^{2}$

agaa

ogogo

agaa

araa

さேンัン

으늠ำ

$\dot{m} \tilde{m} \tilde{\sim} \tilde{\sim}$

$\infty \infty \infty \infty \infty$

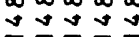

으는은

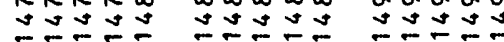

テேン̃

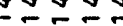

$\stackrel{0}{\sim} \div \simeq \stackrel{\sim}{\sim} \backsim$

inoogio

gungimin

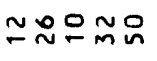

品品出告

กทีกะก

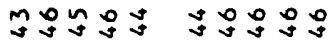

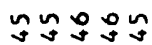

舟す5テ

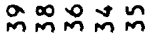

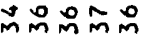

ํํํ웜워

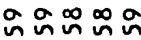

的识品昌品

ตำำ?

ำำำ

ติำณ

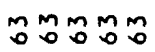

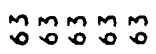

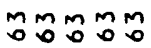

MำM몽

monmm

ติำตำ

\section{a

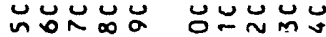 \\ กヘヘヘ̃

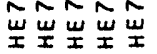

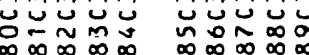

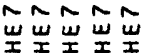 \\ $\sim$}

mmmmm

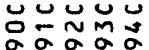

岀出出秸

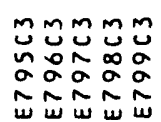

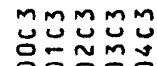

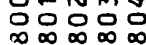

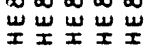

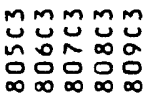

w w w w

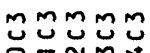

$O=\sim m v$

$\infty \infty \infty \infty \infty$

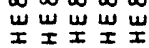

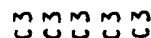

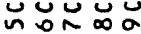

$\infty_{\infty}-\bar{\infty}-\infty$

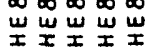




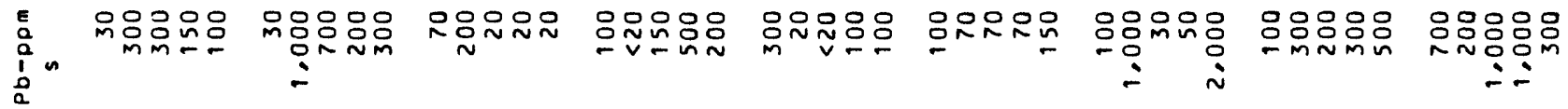

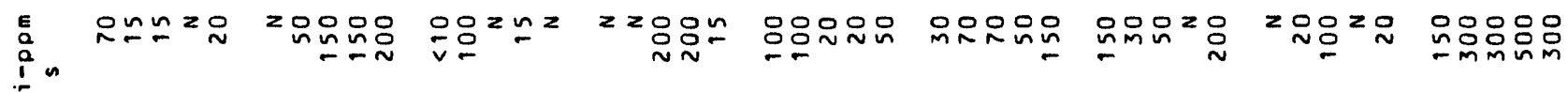

E

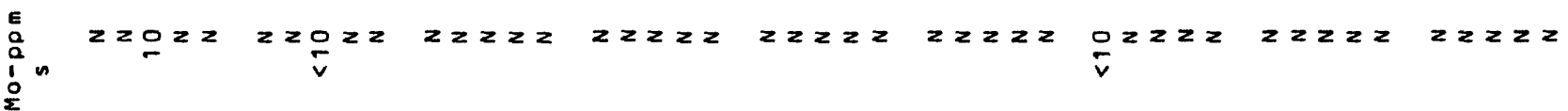

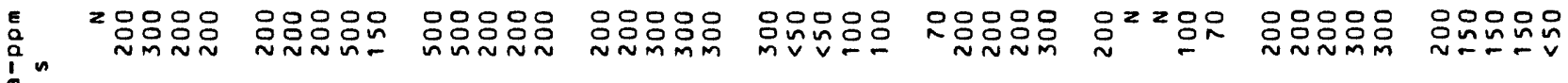

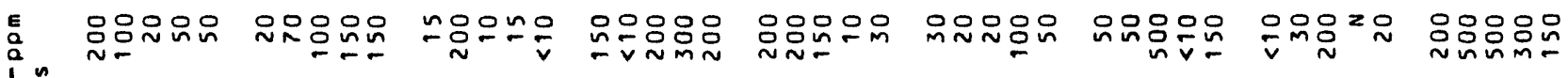

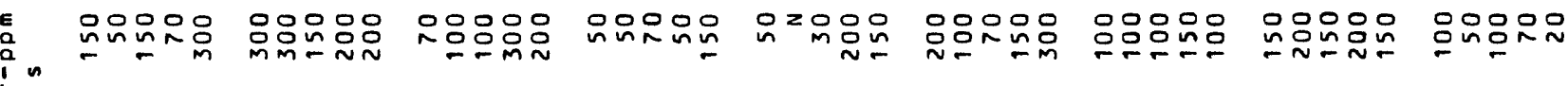

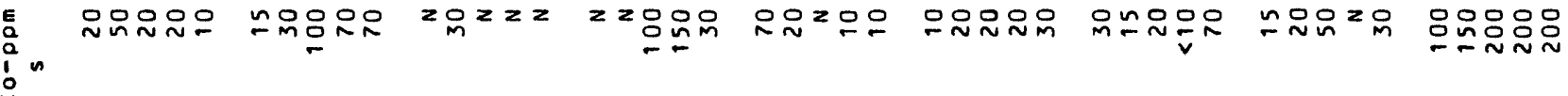

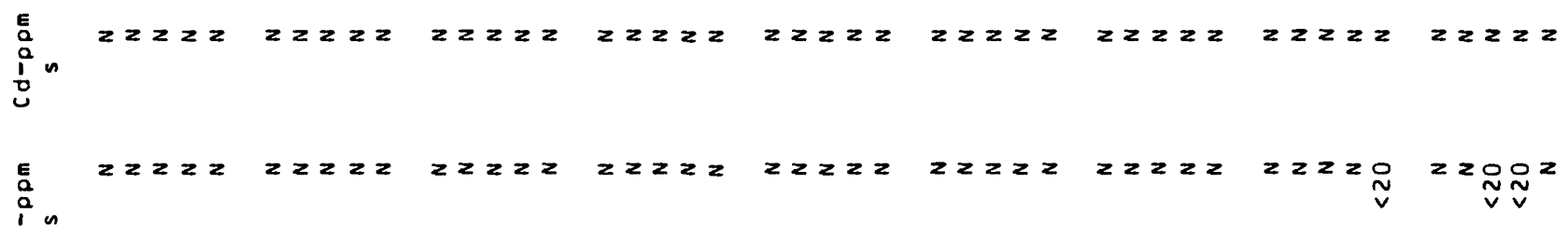
m

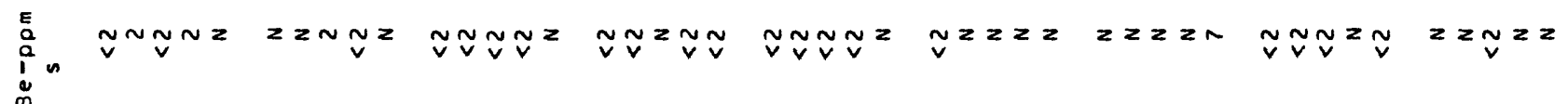

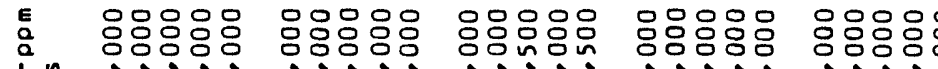
in vóojo jóndo móñ

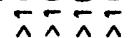

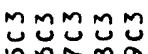

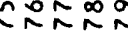

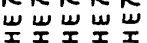

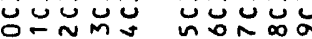

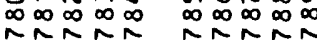

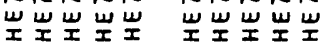

mumm वू̃ăa

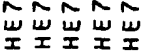

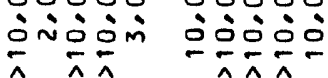

응옹용ㅇㅁㅇ옹

응영응응음

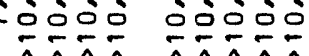

응음음응용 iñós óvimí $\wedge \leftarrow \wedge$

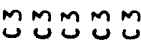
등도음 순요

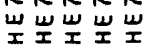

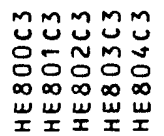

MMMMM

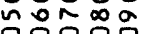

잉에

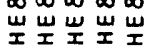

úvmm $0-N M$ $\infty \infty \infty \infty \infty \infty \infty \infty \infty \infty$

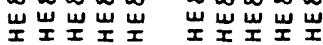




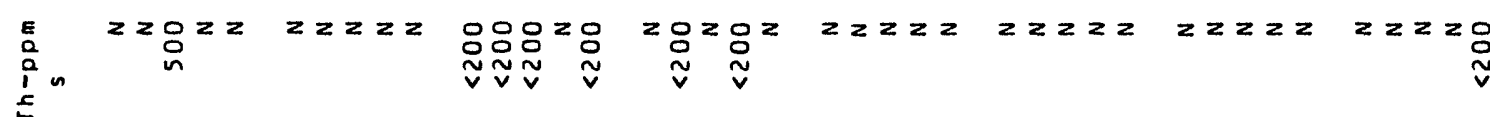

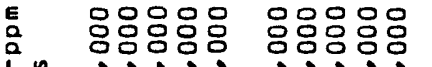

$i^{n}-\dot{\sim} \sim \tilde{\Lambda} \tilde{\Lambda}$

$\dot{\sim} \dot{\sim} \dot{\sim} \dot{\wedge}$

응응응응응

$\sim \tilde{\sim} \sim \dot{\sim} \dot{\sim}$

응ㅇㅇㅇ응용유

영윰윰

응음윰유

웅음움음

응융융영

양융ㅇㅇㅇ음

$\begin{array}{ll}\text { E } & z z z=2 \\ \text { a } & \\ \text { in } & \end{array}$

$0<2 z 2$
$\stackrel{n}{v}$

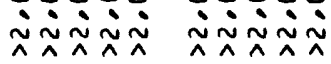

i் $\sim \dot{\wedge} \sim$

ì

E
I

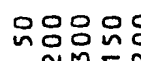

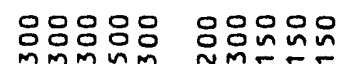

용ㅇㅇ

$z \geq z \circ 0$

$\begin{array}{ll}0 & 20 \\ 0 & 0 \\ \vdots\end{array}$

$0<2<0$

응요

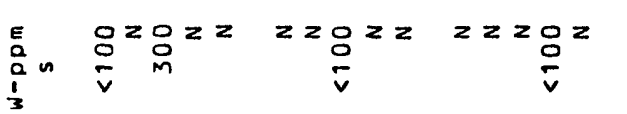

영은 $=2$ 연

$z z z z$

$z z z z 2 z z 2 z$

$z z z \frac{0}{\frac{0}{v}} \quad z z z z z$

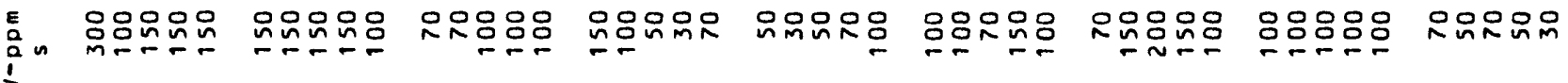

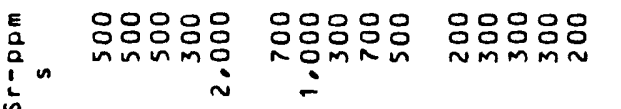

양요

$8: 88:$

요요요

용요

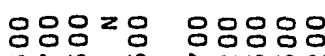
in:

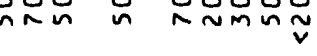

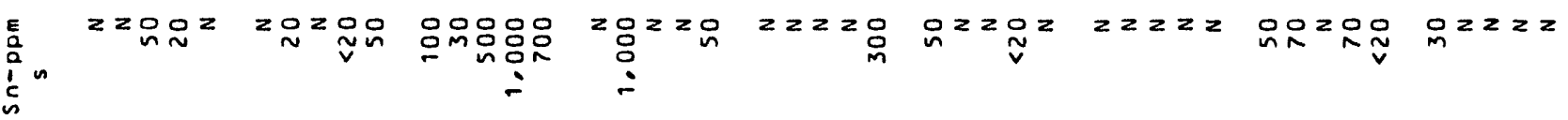

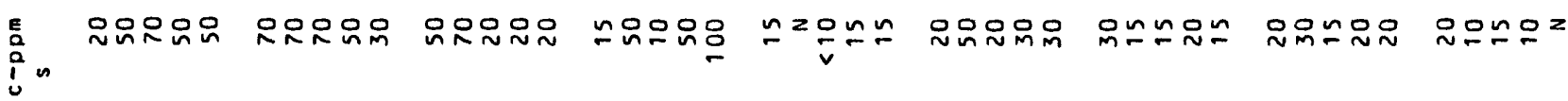

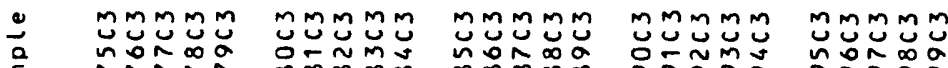

ลกล̃ล

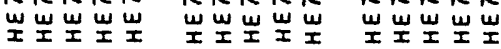

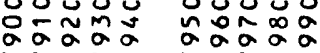

ヘnヘN

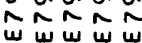

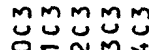

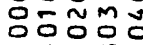

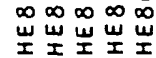

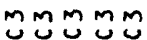

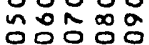

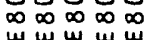

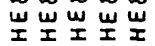

mmmmm

은동

$-\infty \infty \infty \infty \infty$

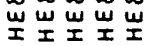

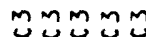

느요

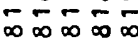

I 
$z z z z$

$z \geq z z$

$z<z$ 용

$z z z z z$

$z z z 2$

$z z z z z$

$z \geq z z$

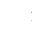

$\sum_{2}^{0} 0$

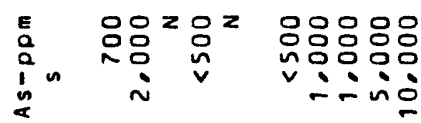

3.ำ

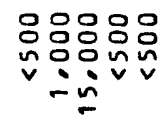

$z z z z z$

$^{2} g^{\circ} g_{v}^{2}$

$z z z \geq 0$

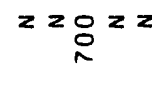

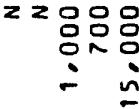

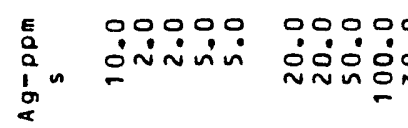

$\stackrel{0}{0}=$ z

$\because z \stackrel{0}{0} \dot{0}=$

$z_{i}^{0}=0$

$i^{0}=\frac{0}{n}=$

$z z z z$

$z=\stackrel{0}{2} \stackrel{0}{0}$

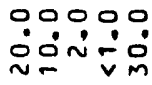

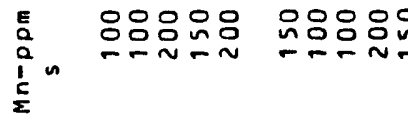

웅요

영용ㅇㅇㅇ

으융요음

88808

80000

음응응

음옹ㅇㅇㅇ

nutn n-nin mi!

जn นñ

UnN

in

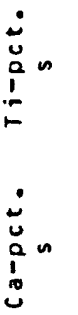

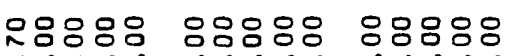

응요

응요음

용요용

응응응

옹요은

옹융ㅇㅇㅁ

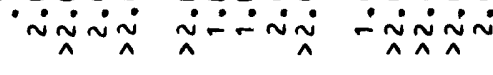

iññ

inini

$\therefore \underset{\sim}{\sim} \dot{\sim}$

iñ $\sim \dot{n}$

$\sim \sim$

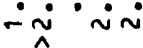

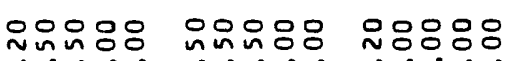

은응ㅇㅇㅇ음

nooㅇㅇ

응요웅요

운용웅요

응응응

옹음옹음

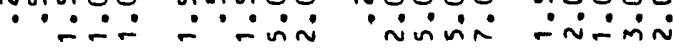

ำกำ

min

$\because \because \because$

iming

niminio

峁

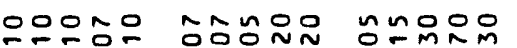

앙ㅇㅁㅇㅜ

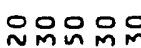

느오욤요

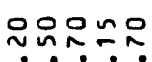

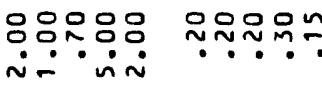

通我

00000

00000

onoon

00000

no000

...

$\because \cdots$

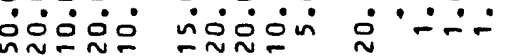

vinini:

- íำ

$000 n n$

noono

no 000

00000

iniñ

omin:-

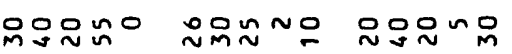

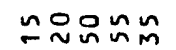

읐으능으

no

$\underset{n \rightarrow \infty}{\pi}$

애으요원

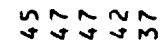

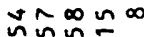

野 $\sim \infty$

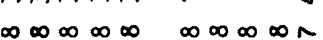

anoug

nNNNA

กNnaa

$\infty a \circ a \infty$

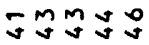

$\infty \infty \infty \infty \infty$

agag

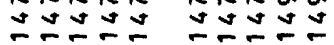

さンシンシ

ษささささ

ㄴำ

ผ $\sim \sim \sim ⿻ 上$

araag

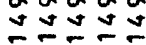

음요 운

INmaO

araag

ปேェェす

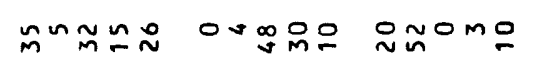

mลกำกับ

กะณำก

mิmฺั

ำ

บำกับ

은으원ำ

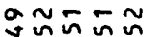

品品的的的

的倠品的

ñag

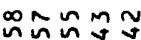

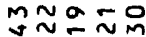

品的的的

무요

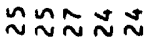

моำตำ

момм⿻ำ

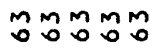

ติำm

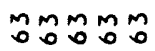

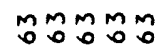

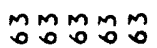

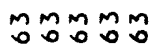

ติำณำ

고요요

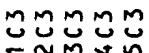
识的织

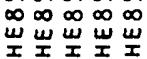

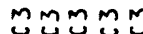

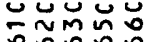
0000

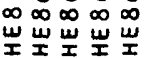




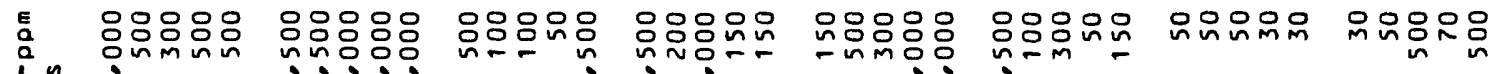

$i_{0}^{0} n$

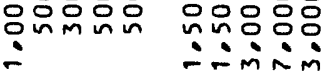

inm

$\because-m-$

in in

옹응운응으 n:

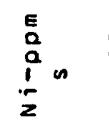

옴웃윰웅은

옹웅응응

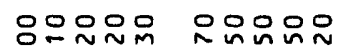

z z응요

옸응ㅇㅇ음

온은은

옷옹ㅇㅇㅇ음

음은은옹

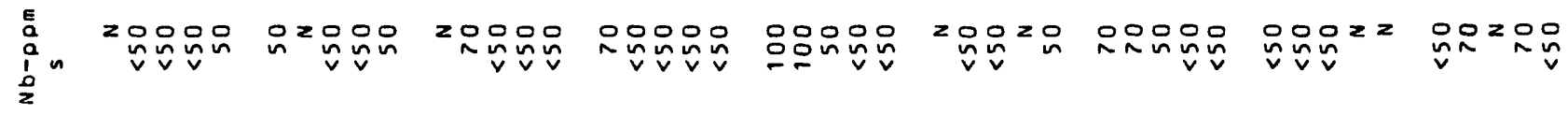

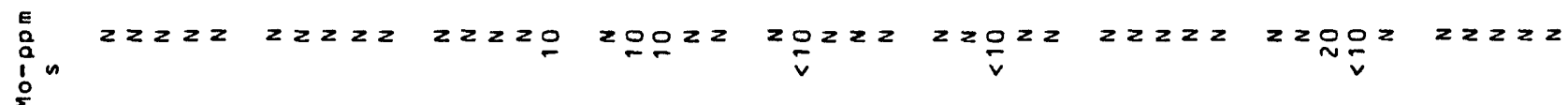

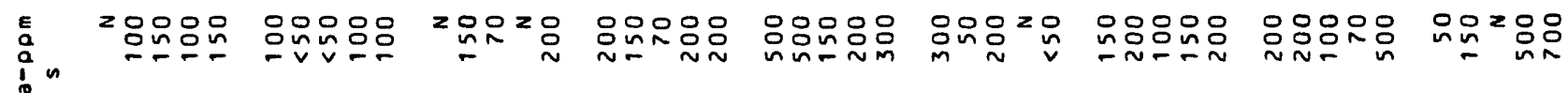

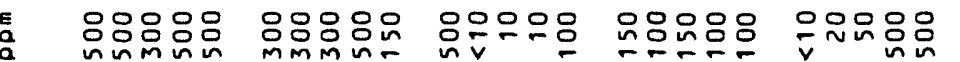
in

$i^{\infty}$

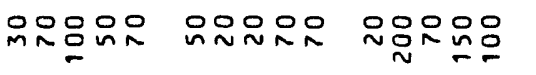

은응ㅇㅇㅇㅇㅇㅇ

웅ㅇㅇㅇㅇㅇㅇ

음언음용

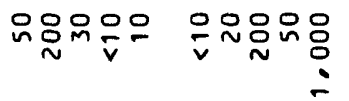

옹음응요

통

000000000000000

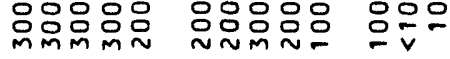
in

$E$
0
0
1
0

$z 2 z 2 z 2 z 2 z$

$z \geq 2 z 2$

$22 z 22$

22222

2222

2222

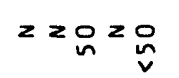

z응으 2

$E$
0
0
$\frac{1}{0} n$

$z z z z z$ 응음요

$z z z z$

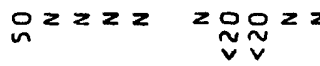

$z \geq z 2 z$

$z z z z$

$\stackrel{\sim}{\sim}$

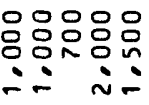

은응은은

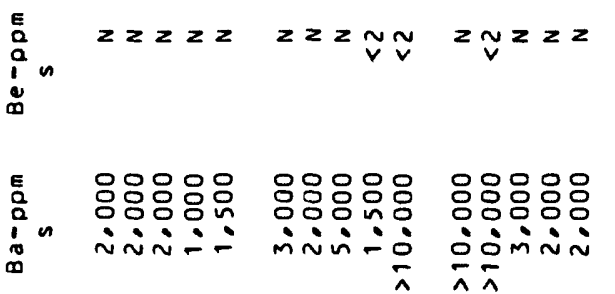

$\sim \tilde{v} z \tilde{v} z$

$z \sim \sim \sim \tilde{v}$

$z \geq z z$

$z 2 z 2 z$

$z 2 z 2 m$

$z \sim z \sim \sim$

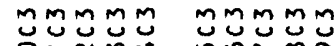

드뉸

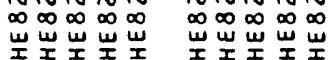

múg uㅗ

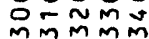

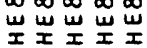

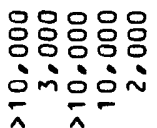

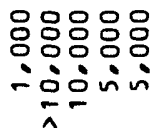

옹음욤용용

就方的

수순

응응용응 inin:

옷은응응음 $\because \because 000$

응응옹응응 웡우

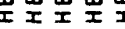

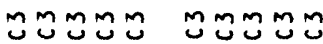
miñ

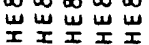

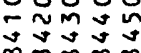
$\infty \infty \infty \infty \infty$

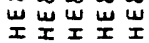

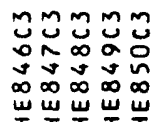

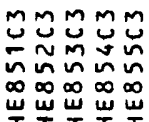

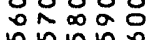
n $n_{\infty} n_{\infty}^{\infty} n_{\infty}$ w

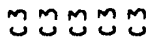

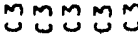
万ั $\infty \infty \infty \infty$ 㞬㞬㞬岌岌 


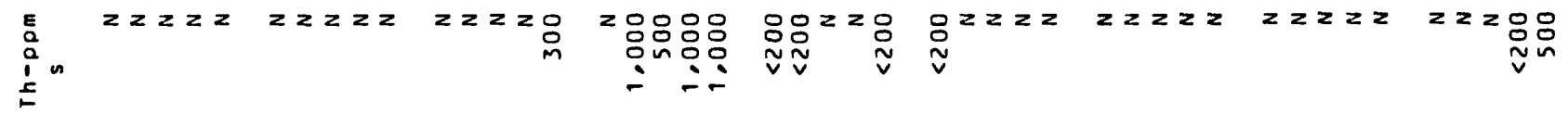

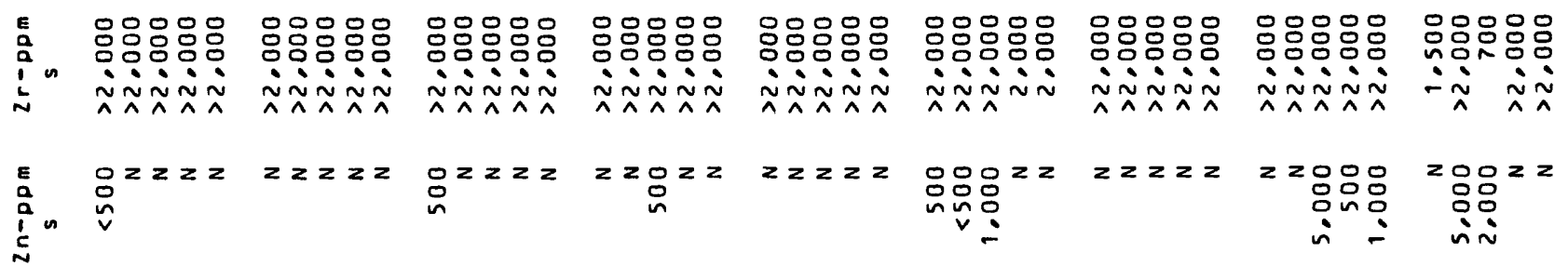

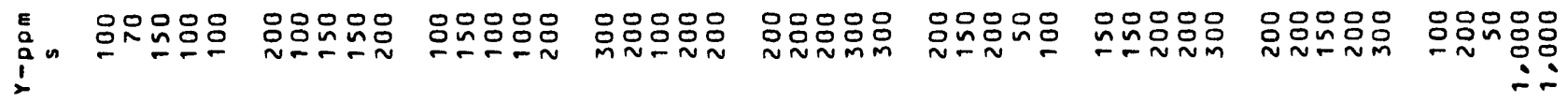

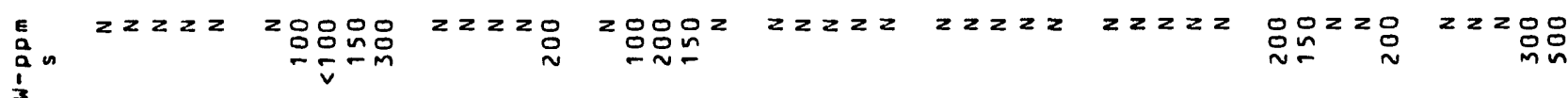

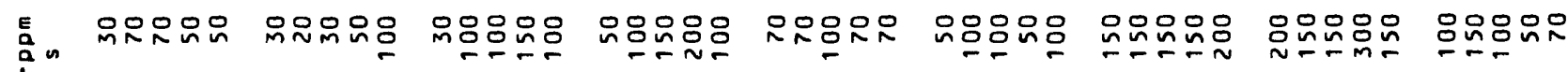
$>$

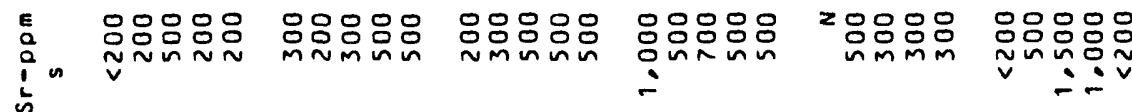

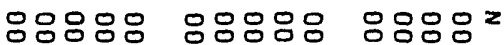
nunun unnoo ngon $\therefore \therefore \therefore \div$

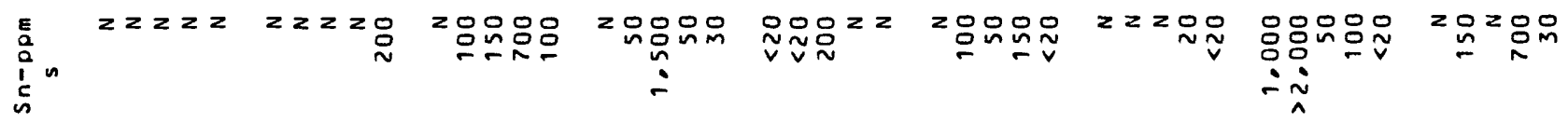
E 음유으 늠으

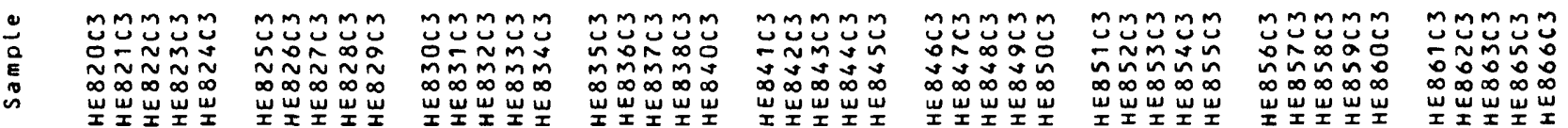




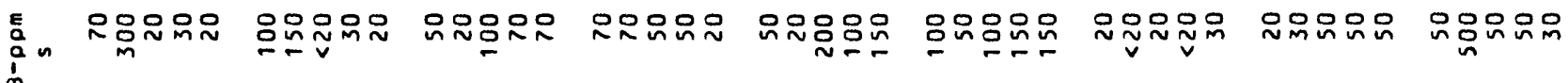

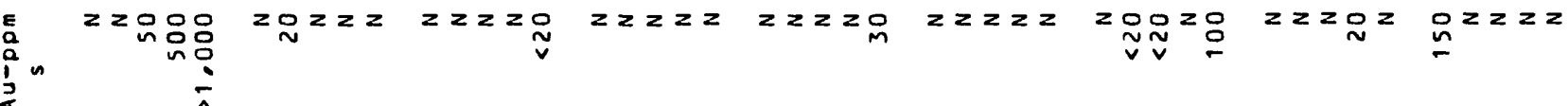

E 9000

웃옹으요

0002

$z g^{2} z=$

욜

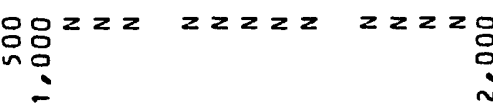

$z=28$

$z<2$ 응응

完总只

$\because \dot{\sim}$

$\because 2009$

io:

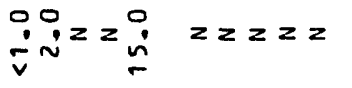

$\operatorname{li}_{\sim}^{0}=0$

$z z z z z z z z$

$z=2 \stackrel{0}{0}$

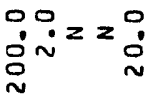

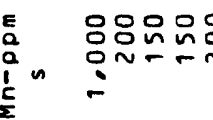

옹옴용응

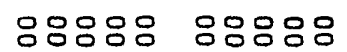

응옹옹응응

응응용응 응응ㅇㅇㅇ음

옹옹옹응응

옹옴옹ㅇㅁㅇ

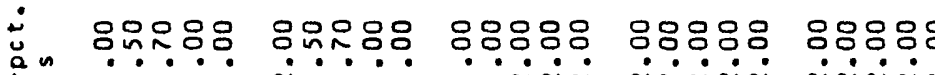

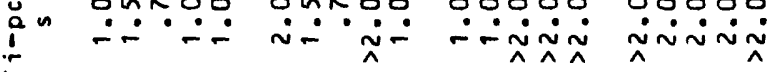

$\ddot{\wedge} \sim \dot{\sim} \sim \dot{\wedge}$

옹용ㅇㅇㅇㅇㅇ 용용용ㅇㅁㅁ

옹용용용

응응응응용

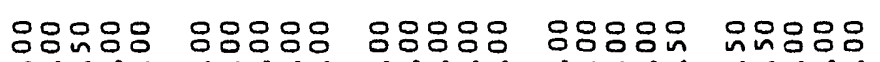

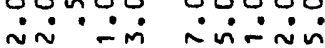

inini

nivini-

$\therefore$ ini

응옹영음응

miñ

옹옹응응응

inini

$\sim \tilde{\wedge} \sim \dot{\wedge} \tilde{\wedge}$

$\dot{\sim} \sim \dot{\sim} \sim \dot{\wedge}$

范n

오옹으

ㅇo으요

잉ㅇㅇ응

웅ㅇㅁ웅

웅ㅇㅇㅇ

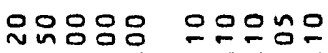

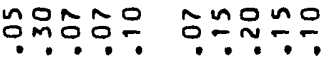

范n

00000 No000

№요ำ

ن inig

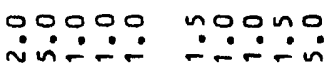

0.0000

nonn

ทกฺn

$00 n 00$

00000

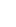

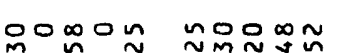

o욤요

음요

용ำ

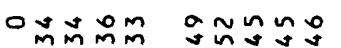

noman

$\stackrel{\sim}{\sim} \sim \infty \sim ⿻ 上$

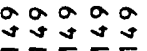

$\mathfrak{ป} \mathfrak{a}$

$\sim \infty \infty \infty$

$\infty \infty \infty \infty \infty$

$\tilde{n} \sim \sim n N$

$\infty \infty \infty \infty \infty$

さேさささ

$\infty$
$\infty$
$\infty$
$\infty$

영응

응유음

mm

m-o

$\infty$

$\infty \infty \infty \infty \infty$

은 (2)

g이앵ㅇ

oำ

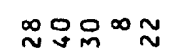

ฯom

moomo

은원요

$\infty \infty \infty \infty \infty$

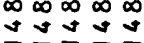

$\infty \infty \infty \infty \infty$

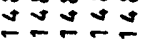

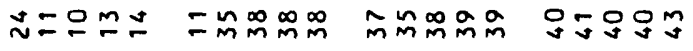

adza

$\mathcal{U} \mathfrak{Y} \approx \pm$

$0 \infty$ ํํำ

$\stackrel{O}{\sim} \underset{m}{\sim} \mathfrak{q}$

옸요

mตถ

mon

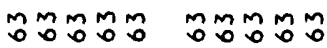

mơ

ติำ

ペンニッ

$m \simeq \simeq m m$

$\pm \pm \simeq a \infty$

monom

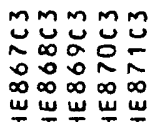

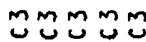

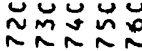

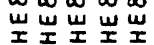

$\begin{array}{lllll}\infty & \infty & \infty & \infty \\ w & w & w & w & w\end{array}$

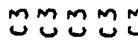

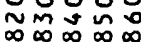

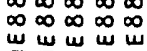

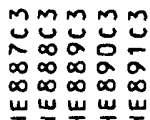

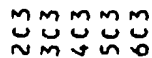

âa

ăa으음

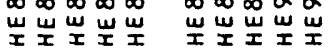

món

món 


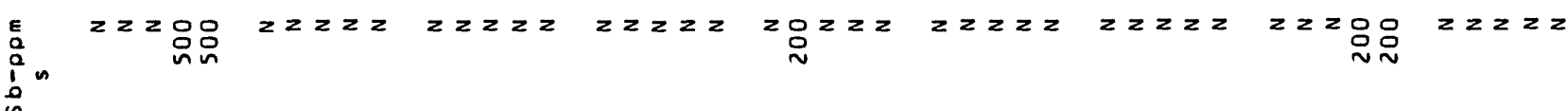

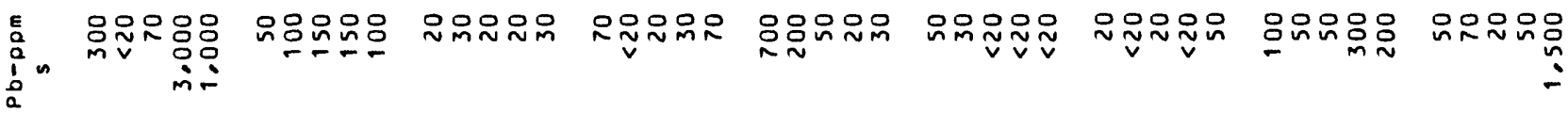

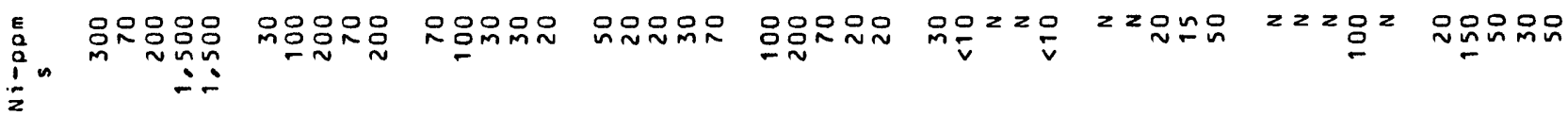

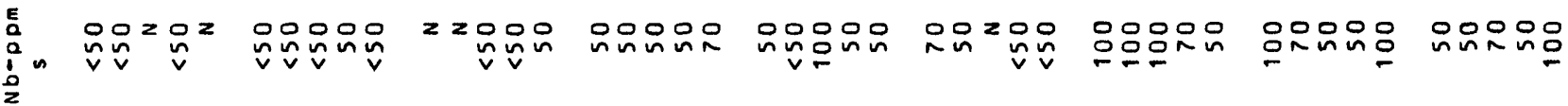

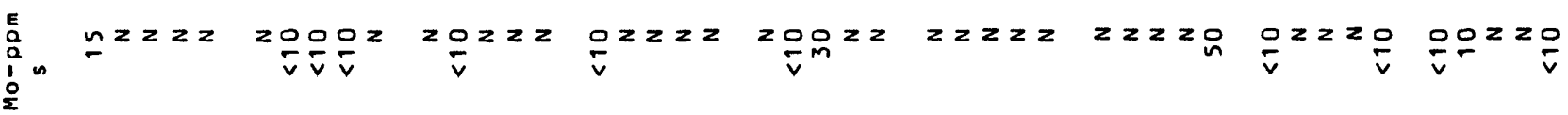

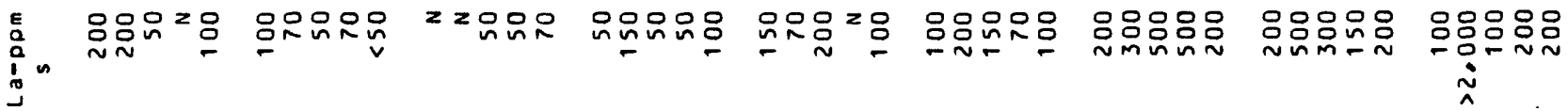

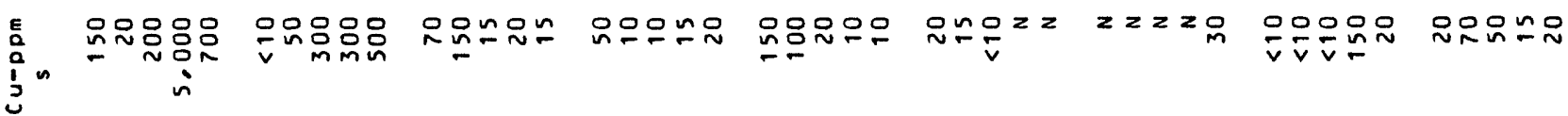

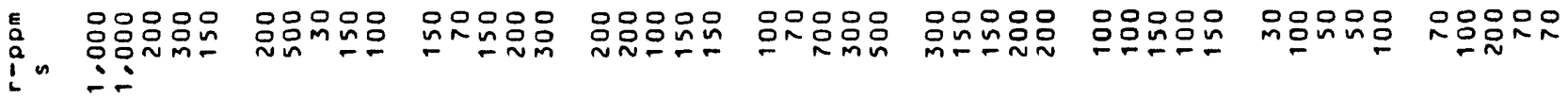

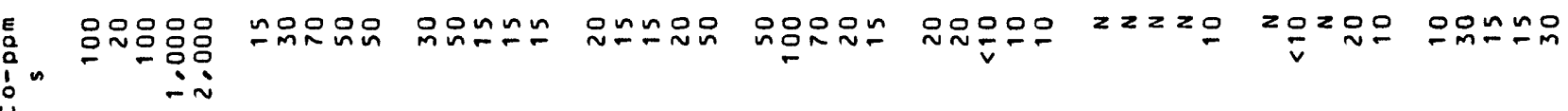

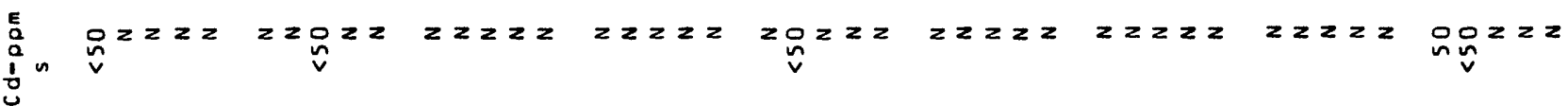

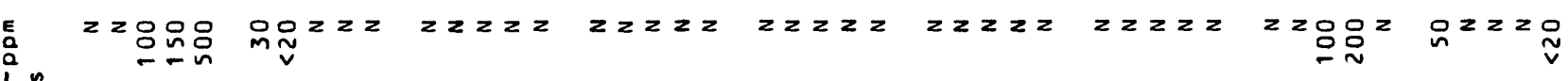
$+\infty$

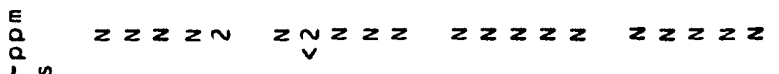
$z z z z z$ $z z z z z \quad z z z N$ non $\tilde{v} z \geq \underset{v}{N}$ an 웃양응응음 ¿ningin

\section{응음염영영}

ionmin

음앰음음

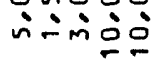

응응용영영

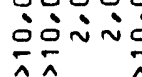
응음음응응 ニㅜ

옴움옹

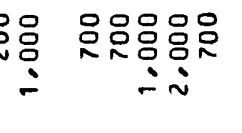
응응영응음 ㅎํㅇㅇํ

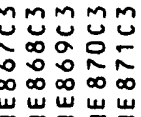

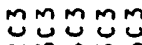

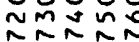

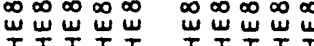

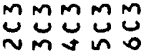
$\infty \infty \infty \infty \infty$ 象

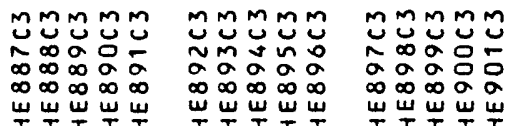

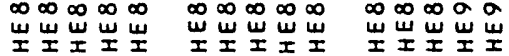

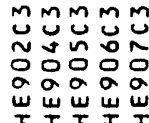

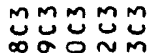
oo은 wa 


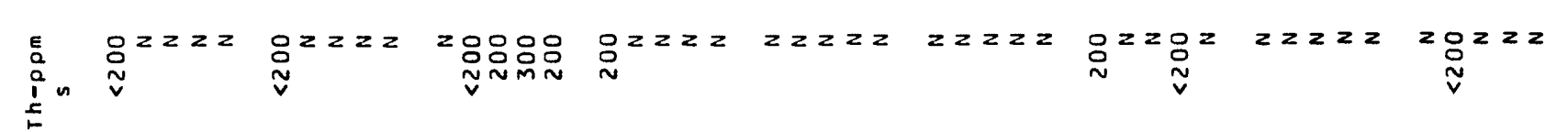

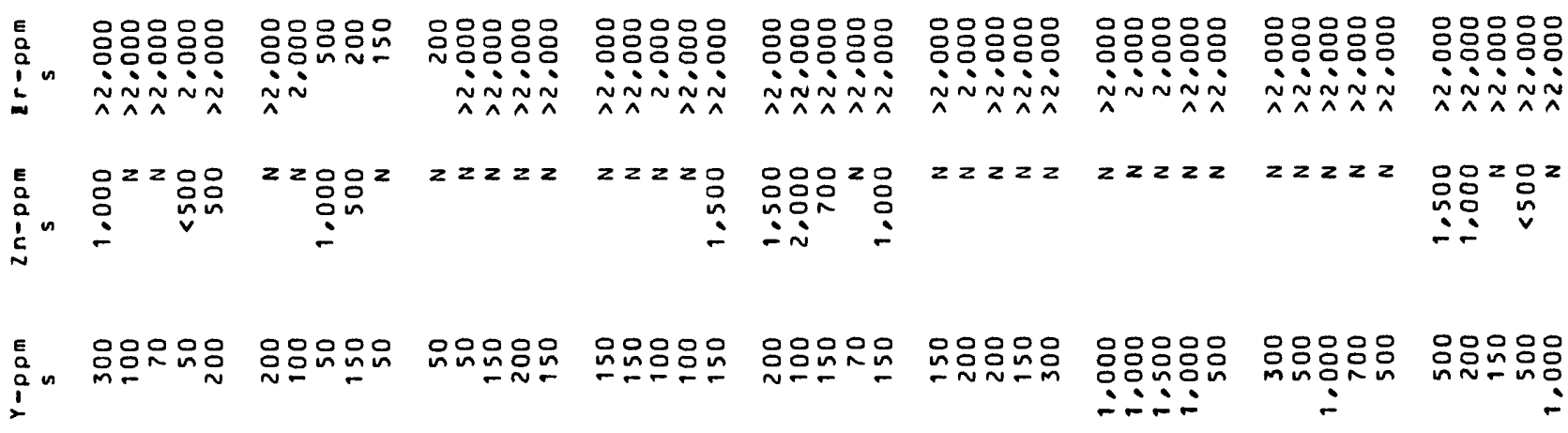

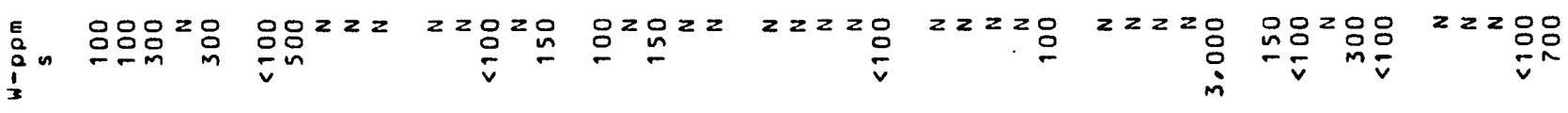

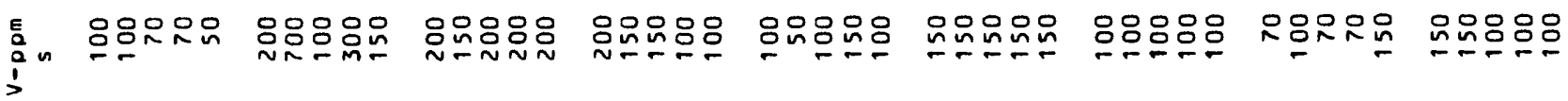

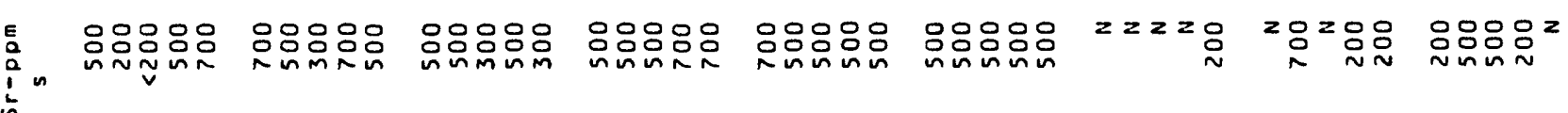

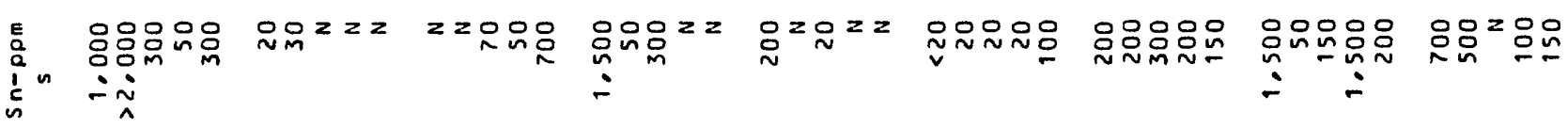

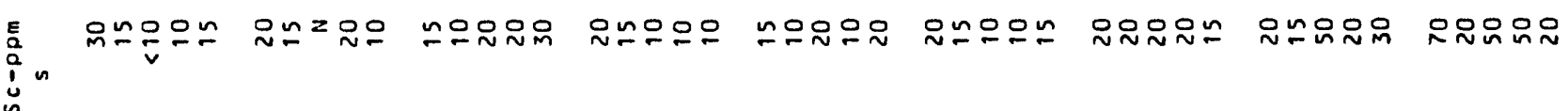

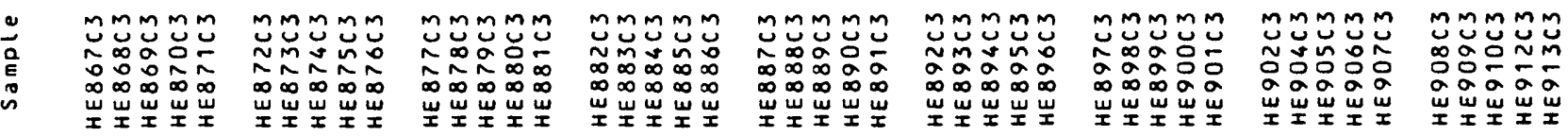




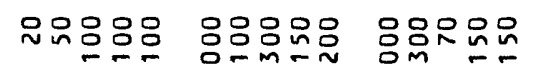

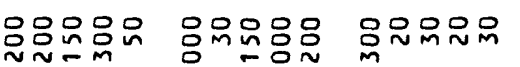

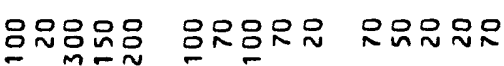

$E$
0
0
$\vdots$
$\vdots$
0

$z 2 z z$

- ñ

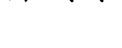

in $:$

$z z z z 2 z 2 z 2 \quad z 2 z 2 z$

욤욤요

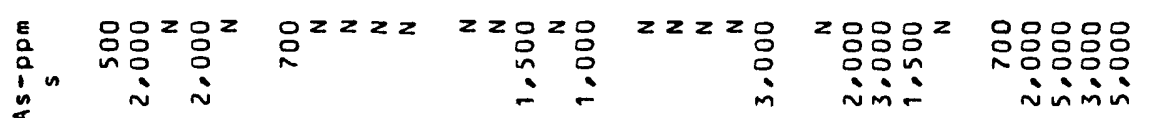

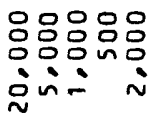

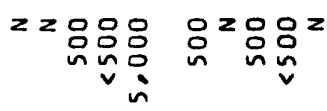

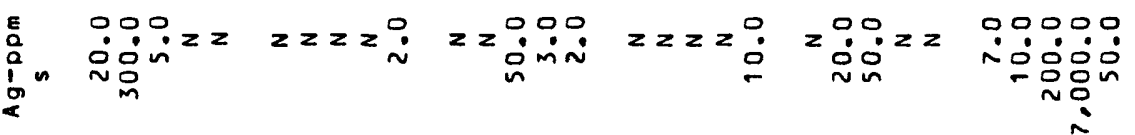

영영요

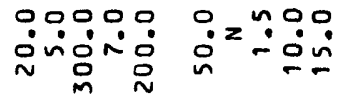

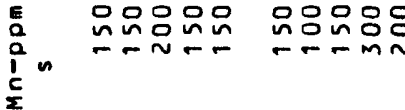

옹ㅇㅇㅇㅇㅇㅇ음

응응응음요

응웅ㅇㅁㅇㅇㅇ

옹요용

음응응은

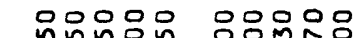

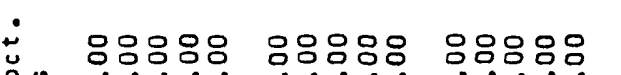

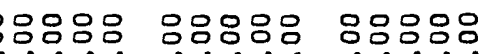

응응응응응

음응응음응은음

in $\dot{\sim} \dot{\sim} \dot{\sim} \dot{\sim} \dot{\sim} \dot{\sim} \dot{\sim} \dot{\sim} \dot{\sim} \dot{\sim} \dot{\sim} \dot{\sim} \dot{\sim}$

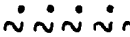

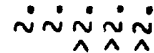

$\sim \dot{\sim} \sim \dot{\sim} \sim$

뚜문

$\ddot{\sim}-\dot{\sim} \sim$

$\dot{\sim} \dot{\sim} \dot{\sim}$

$\dot{3}$
$\vdots$
$\vdots$
0

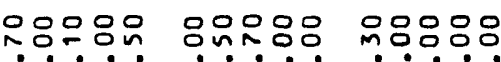

옹응응

웅응요는

옹은은응

ํำ

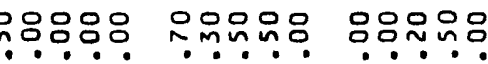

inimi

vivivi: $\because \dot{\sim}$.

$\because \because \therefore$ ํㅜ

vinivin

$\stackrel{\leftrightarrow}{u}$

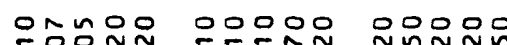

응윰음 등으음

음ํํํํำ

응응음

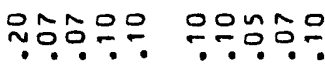

$\vdots$
$\vdots$
$\vdots$

oonoo

oonon

-

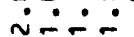

- inim

$\cdot \cdot \cdot$

n்ำ-

nำ?

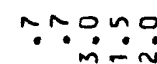

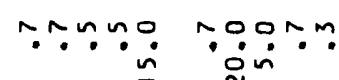

:0000

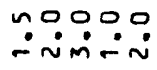

0,0000

00000

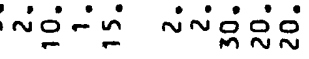

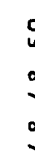

유 $\sim$ m

$\cos 2 \pi$

에요

음는

m요요

ra

$\sim \underset{\sim}{\sim} \tilde{n}$

$\cong 0 \infty \sim m$

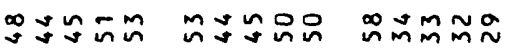

$\sim ⿻ \infty 0 \% \tilde{m}$

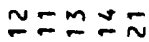

음요

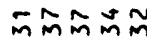

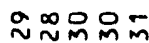

min-mo

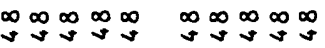

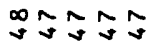

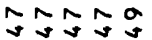

$\cos 00$

$\operatorname{gog} 90$

ogago

최ำ ปิง

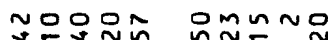

$m n \simeq \simeq 0$

$\simeq \sim \infty \infty 0$

ᄁㅇํㅇำ

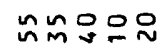

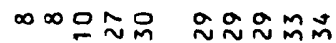

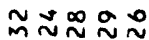

$\infty \simeq \simeq=n$

n D Onm

$m m-N \sim$

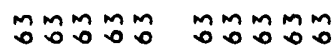

$m$ moño

móño

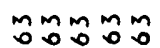

móños

$00 \div \infty=$

nO⿻ñ

ㄴำ

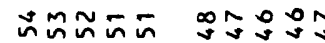

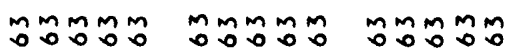

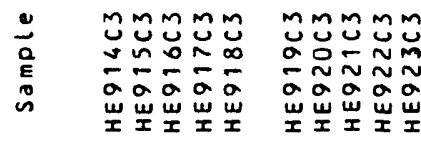

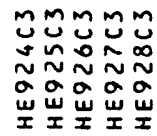

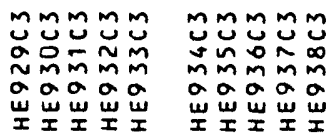

mựmm

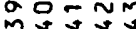

ตัaेa

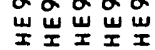

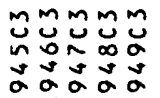

㭊岕峲

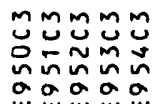

mmmmm

ññ ñoñ

oaa aूăa 


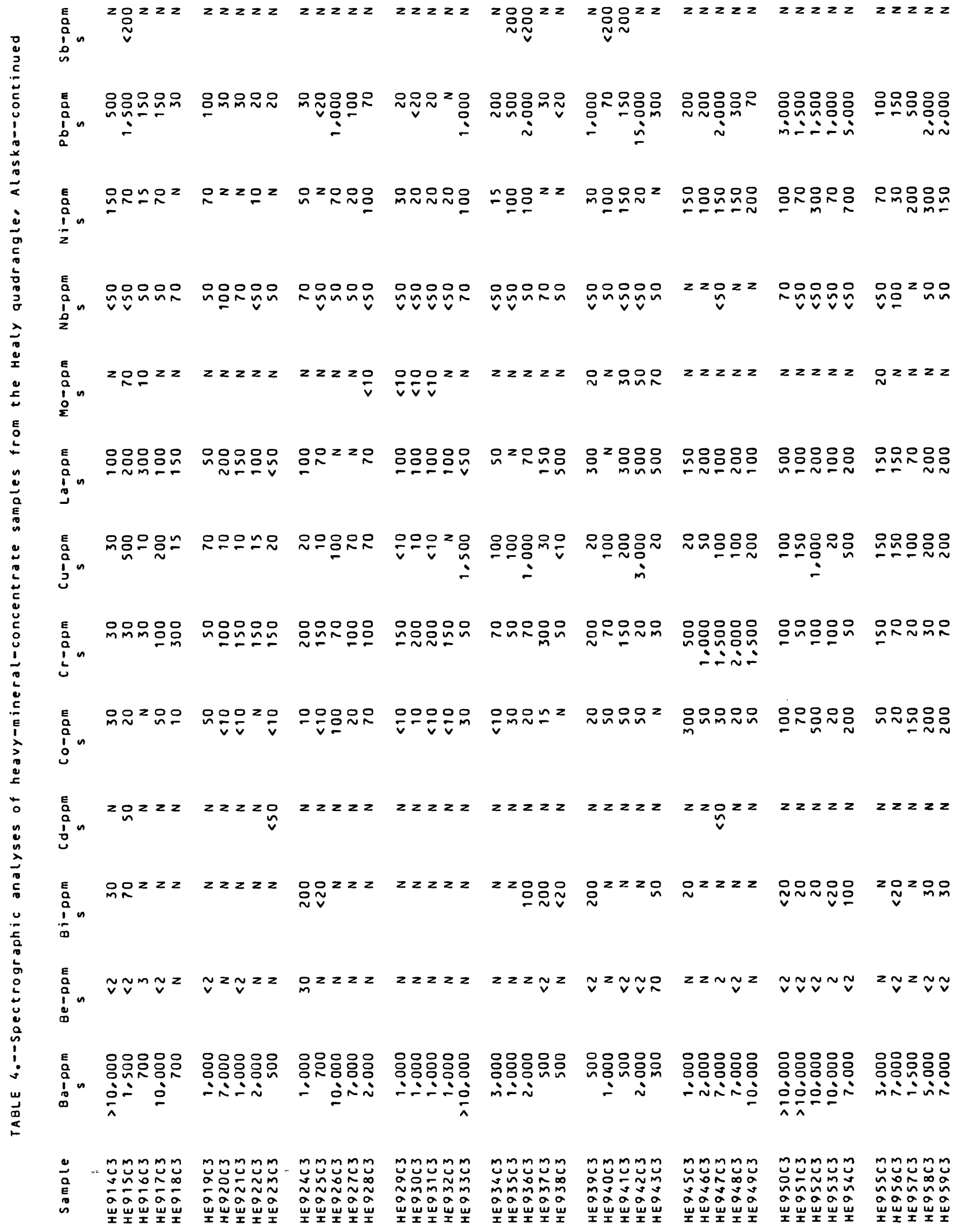




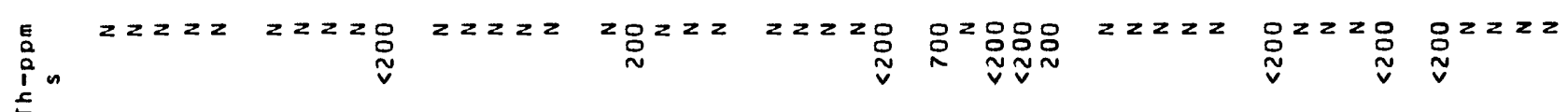

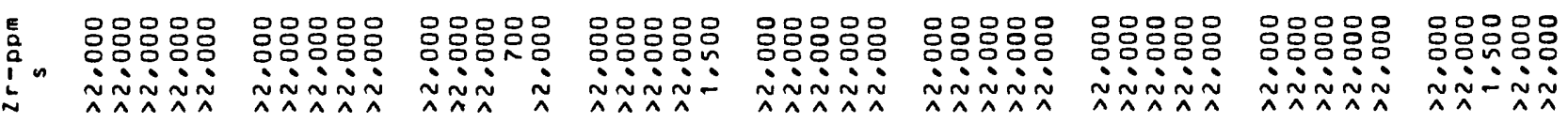

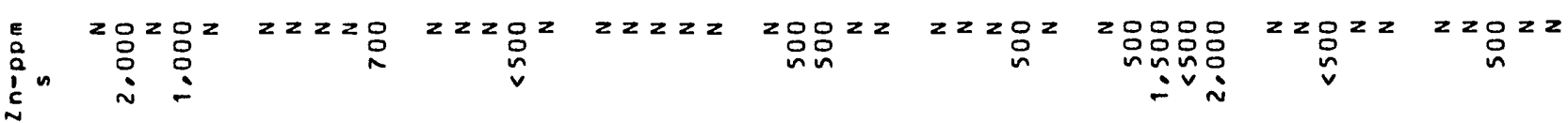

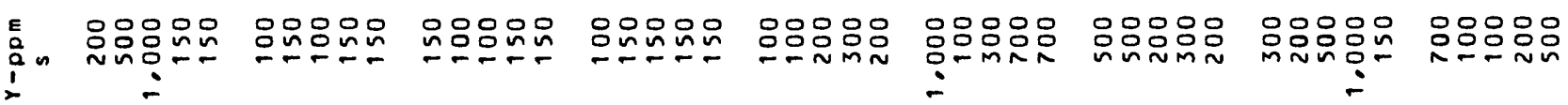

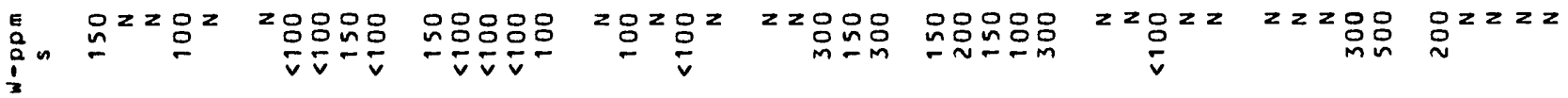

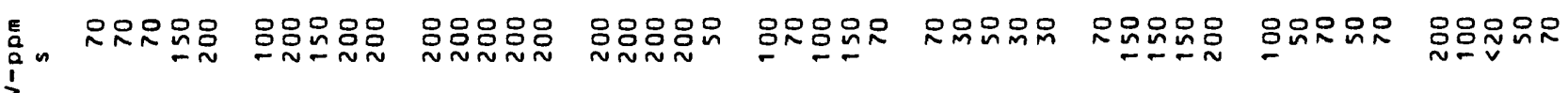

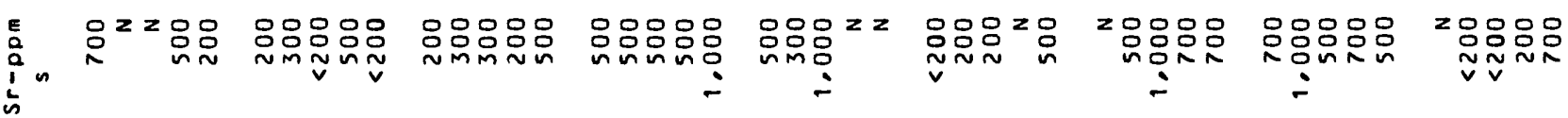

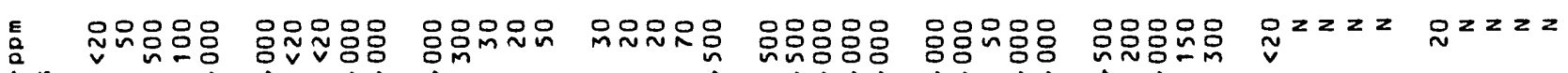
in

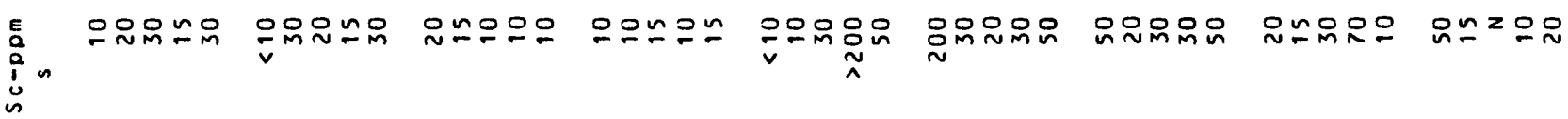

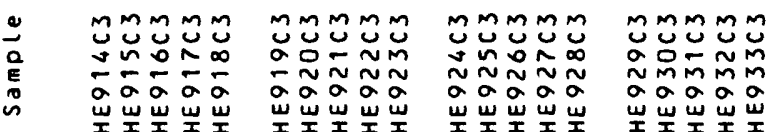




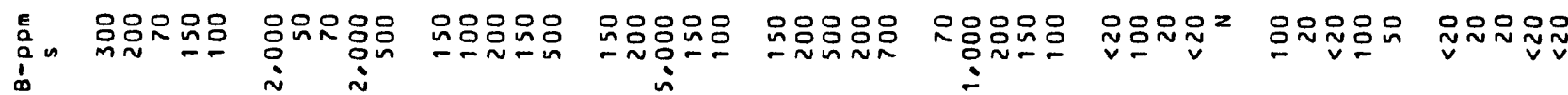

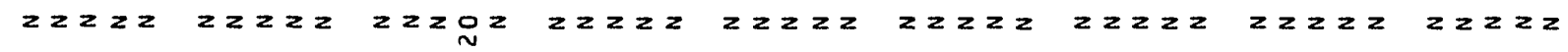
$\sum_{\substack{a \\ 0}}^{\circ}$

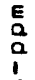

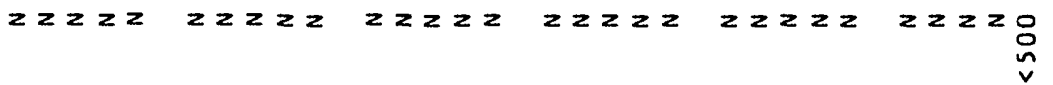

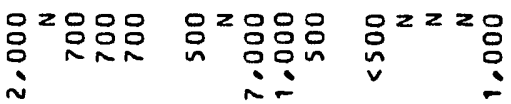

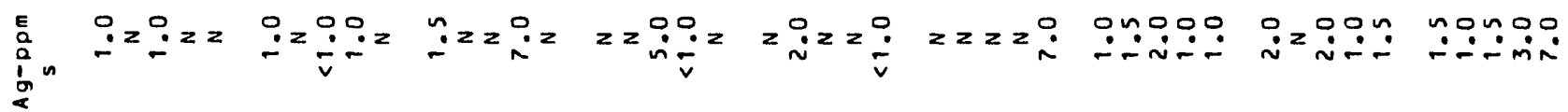

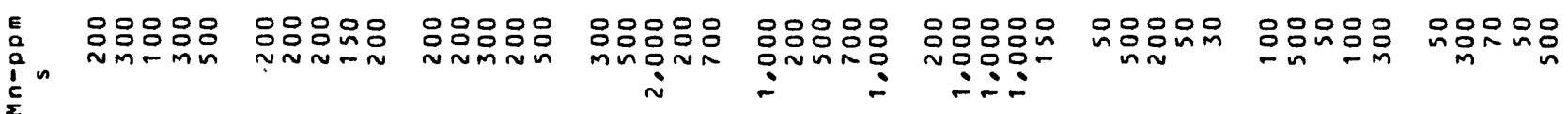

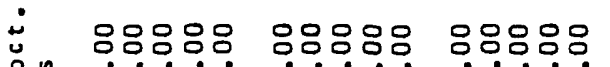
in $\dot{\sim} \sim \dot{\sim} \sim \dot{\sim} \sim \dot{\sim} \sim \dot{\sim} \dot{\sim}$ $\tilde{n} \sim \sim \sim \hat{n}$

ㅇㅇㅇㅇㅇㅁㅇㅛ $\dot{\wedge} \tilde{\wedge} \dot{\sim} \dot{\wedge}$

용ㅇㅇㅇㅇㅇㅇㅇㅁㅇ

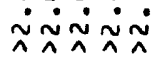

응응응응응

웅옹ㅇㅇㅇㅡ

있유융ㅇㅇㅇ

옹옹ํํ으

$\dot{a}$
ann
$i$
0
0

응응응응음 옹응애는

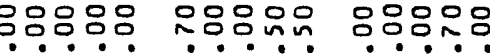
$\sim \ddot{-} \dot{\sim} \ddot{\sim} \dot{\sim}$

iํำ?

욱응음요웅

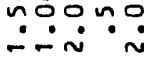
응응용으.

옹옹영응 -0்0-

운음운으

웅으용음 m. -

응유응ㅇㅇ $-n$

응ㅇㅇㅇㅇㅇ

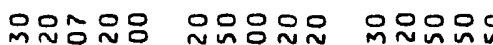

ă on $\because \because \div$ m.กำ? 은옹으응응 은응오응 $\because$ i. i n 은옹ㅇㅁㅇㅜ i in ㄴ? $\div$

느능응 $\because \div \div$

- 0000000000 00000 00000 00000 00000 ñن்ini nimimim กminim

nininim nivinin Nivinio

00000

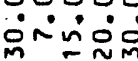

00000 님ㅇㅇㅇ

00000 \&

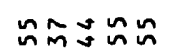

$m \infty \sim m \infty$

늠ํํㅇำ

mกnnท

$m \leq m$ m n

nn nn $n-\infty$

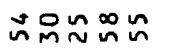

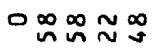

ำง ษับ

miñms

욜 $\sim \sim ⿻$

agaga

agago

om 00

क maga ajaga

araag

$\operatorname{casacas}$

$\infty m \backsim \bar{m}$

온윴요

agaga

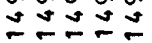

$m \sim m m^{n}$

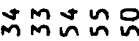

araa

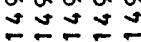

தómin

ํำำำ

$0 \infty n n 0$

$0 \pi 20$

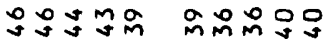

商品的的

ตูำ

môn

môn

\section{nงกั}

$\approx \stackrel{\infty}{\sim} \underset{\sim}{\infty} n$

ก⿻上กำ

ตีกีํำกี

ติํำ的品空

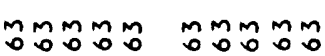

móñ

$﹎{M}^{\infty} \mathfrak{m}_{m \sim}$

$\stackrel{\infty}{\sim} \underset{\sim}{\infty} \sim$

은으무

กิกีำ

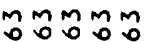

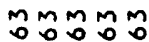

Doong

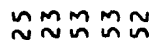

moy

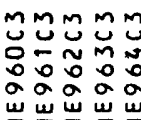

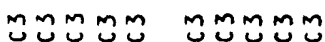

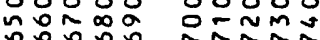

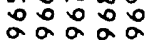

또ㅍㅗㅗ

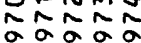

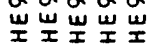

mMmmm mmMmm

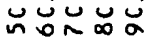

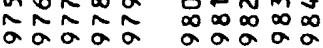

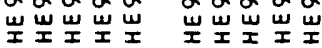

mmmmm In 0 åa

포ㅍㅣㅗ

mmmmm

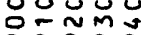

مूa

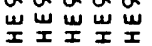

mmmmm

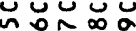
مаㅇaㅇ

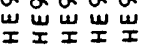

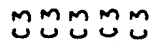

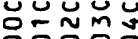
옹응웅응

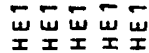


이응

은응ㅇㅁㅇㅛ

n $\operatorname{nin}$

음은음응을

옹옹ㅇㅁ응오

응응ㅇㅇㅇㅇㅁ

온 $\underset{v}{ }=0$

옴응응으

옹응응응응

응웅유음

$\frac{E}{a}$

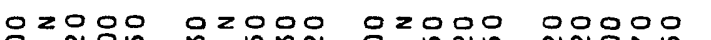

은

min

- $\operatorname{con}$

은

응응으

은옹응 음웅음은

은은옷음은

옷은은음은

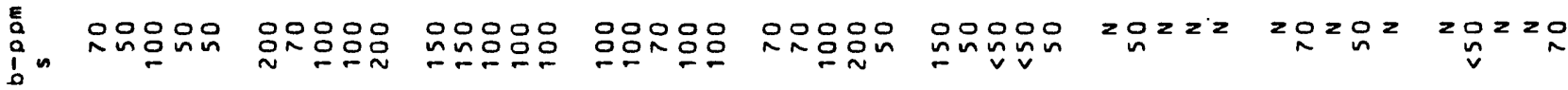

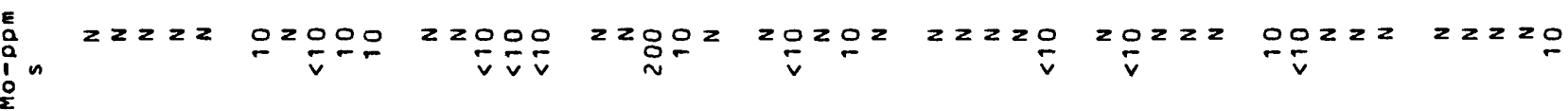

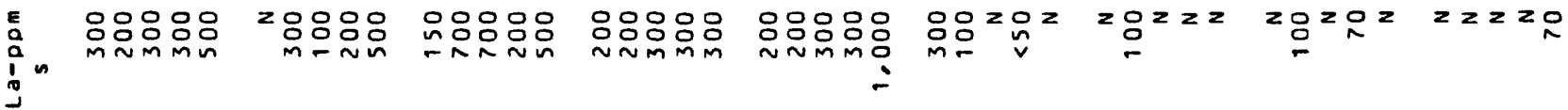

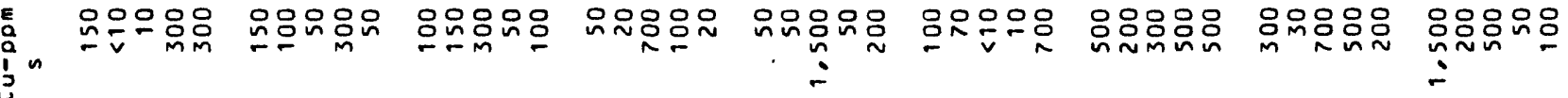

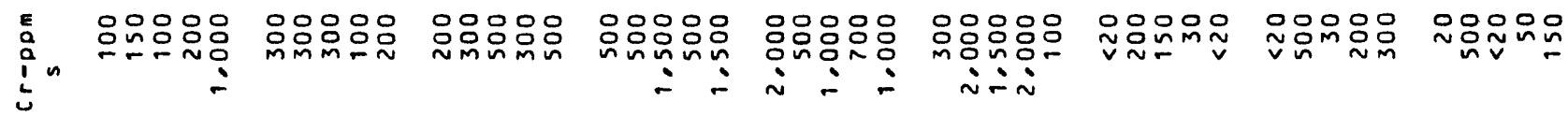

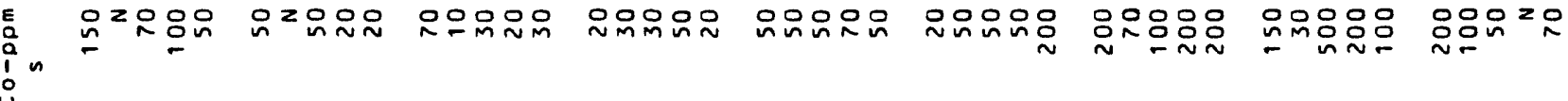

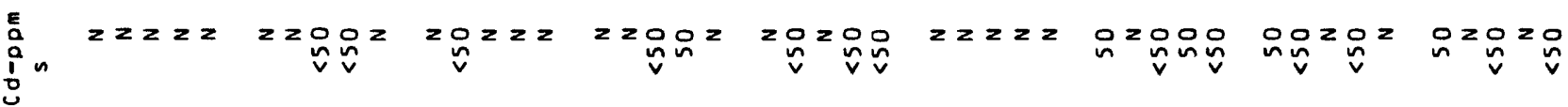
E $\infty$

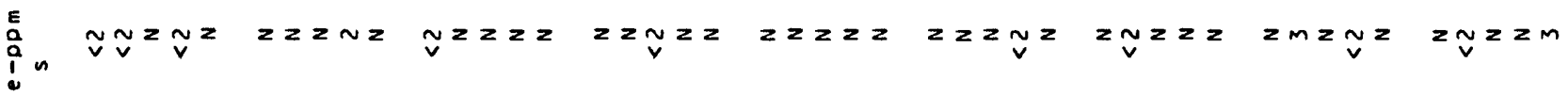

E

in mionin

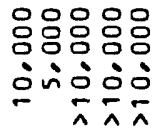

응용ㅇㅁㅇㅇㅇ웅

응응용우

웅음

응암움음

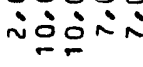

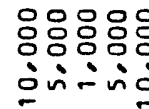

얌음융유

ㅎํㅇㅁ

응응응응응

움ㅇํㅇ

응응응용용

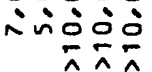

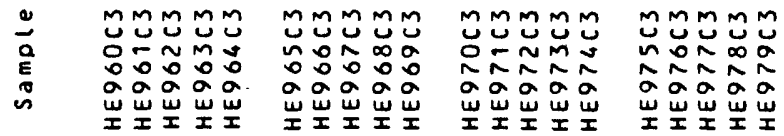

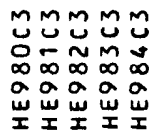

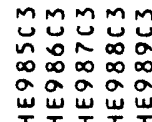

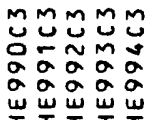

M보넌 乞ํํํㅇㅇㅇ ăa

MMMMm

는돈 응응응응음 ww ww w ш ww 


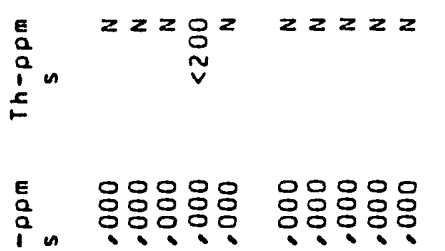

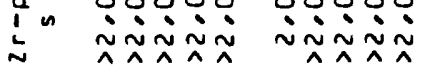

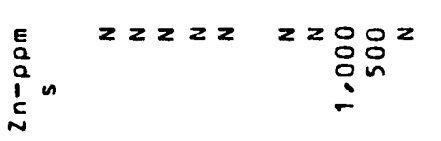

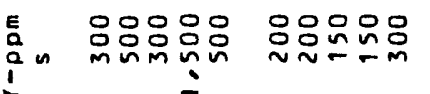

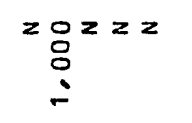

22002

영용ㅇㅇㅇ 응윰융윰

i泫玄

洨交

응응융음

i交亦

응응음용응

i்

음음용유

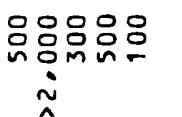

은융ㅇㅁㅇㅇㅁㅇ

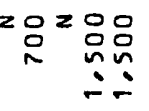

$z: 2 z=$

m 2000

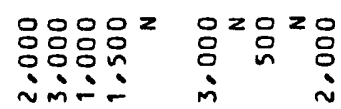

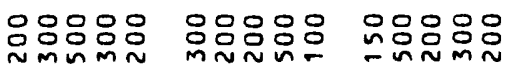

웅응응은

응유융ㅇ

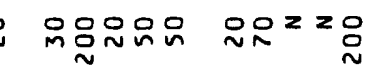

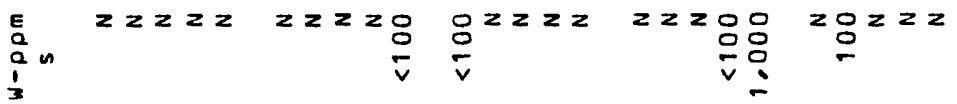

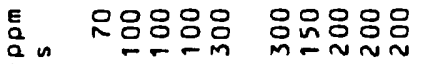
$i^{1}$

帘n

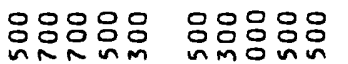
ำ

용요욤요

品品品品

옹요음은

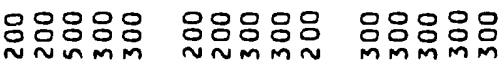

-

ह ${ }_{\text {in }}^{\text {in }}$

z品品 $z=2 z=$

영웅요용
i

운윰유
i

2 웅워 2

앙 $2 z z$

옷음웅윰요

옹요옹

$E$
$\vdots$
$\vdots$
$i$
$\vdots$

웅옴욤옹

는 유욤요

응윰ㅇㅁㅇㅁㅁ

옹응으 


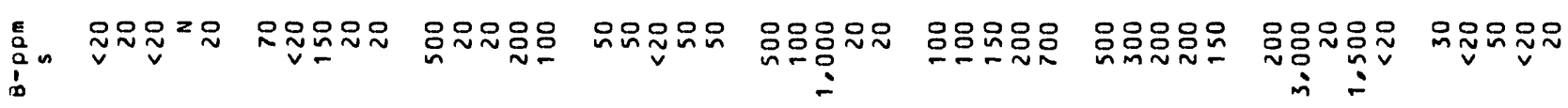

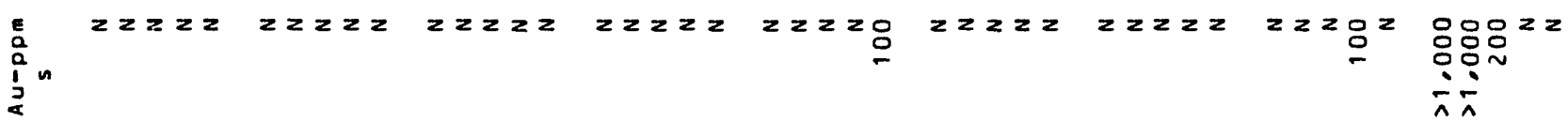

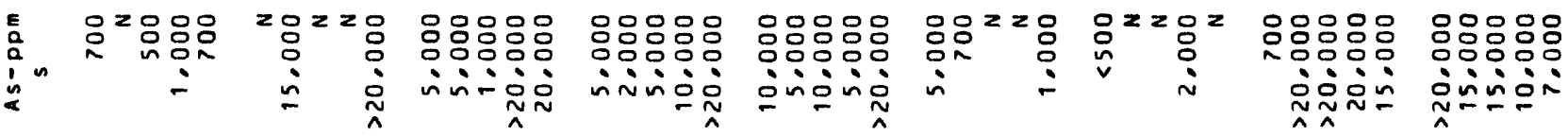

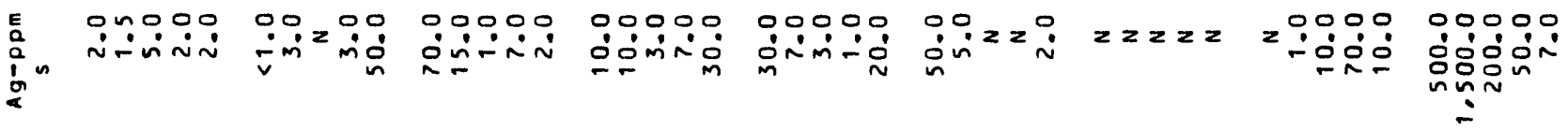

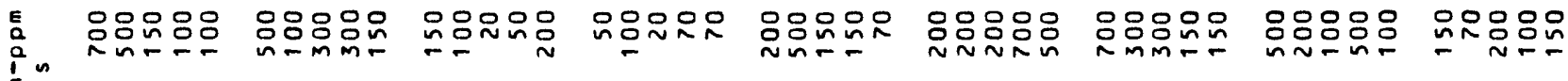

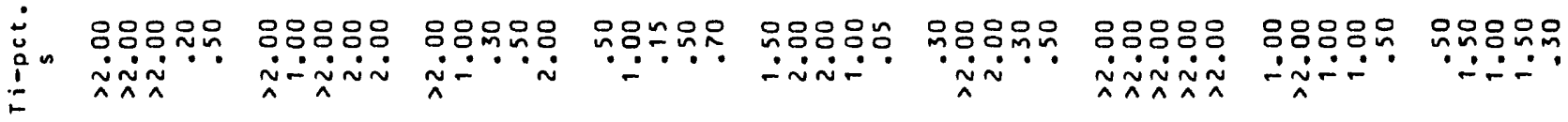

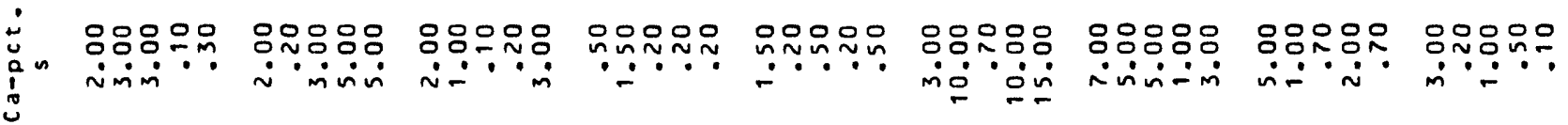

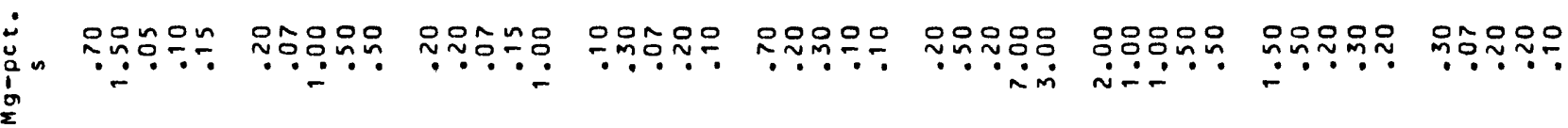

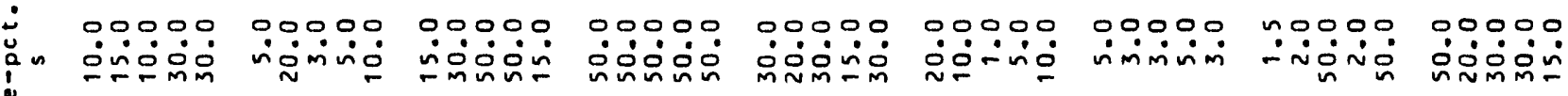
i

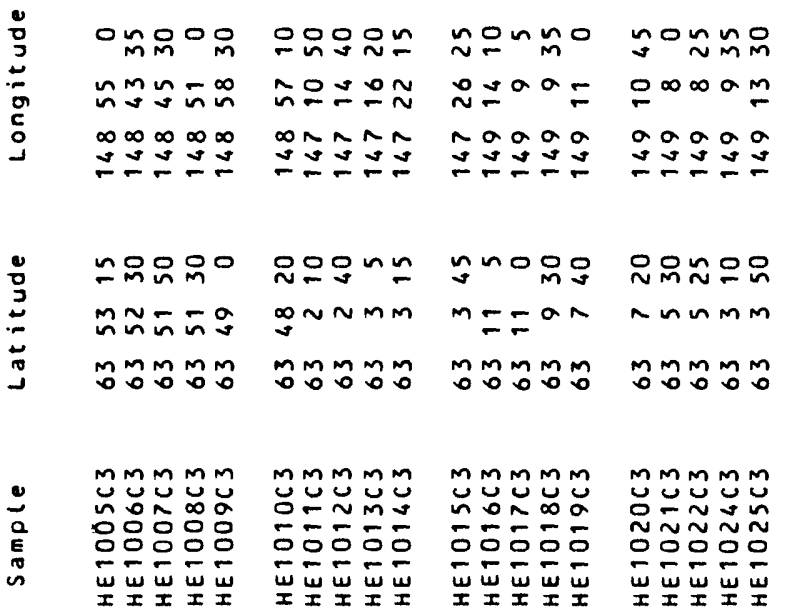

$\approx \approx$ 웅으

으ำำ

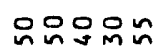

응ㅇㅁ음ㅇ

능ำ

$m \sim \sim \infty \infty$

씀ํํํำ

$\approx \stackrel{\infty}{\sim} \approx 0$

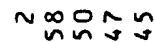

$\approx \sim \sim \sim \infty$

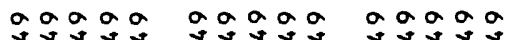

$\infty_{\infty}^{\infty} \infty \infty$

$\infty \infty \infty \infty$

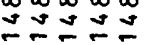

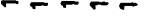

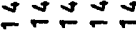

エンンテン

ํํㅇำ유ำ

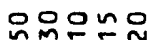

은묘n

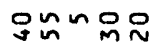

NMNOO

noan-

-mo0o

nTaO

mommm

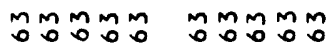

Mำmm

ำำำ?

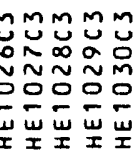

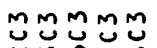

ñmmín

mmmmmm

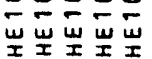

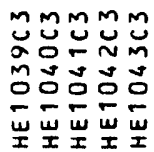

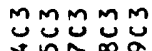

ปี

ํํㅇํㅇㅇㅇ

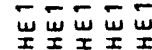

Mํㅗํㅗㅂ

O-NMS

กำกำก

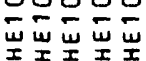




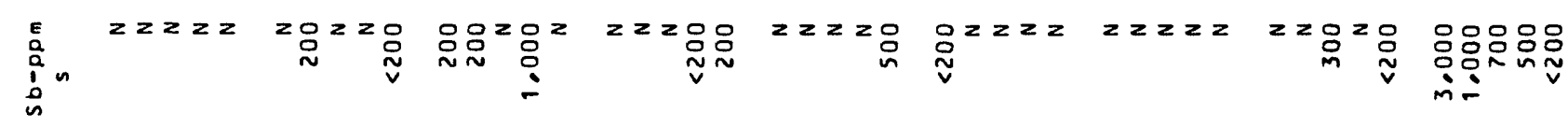

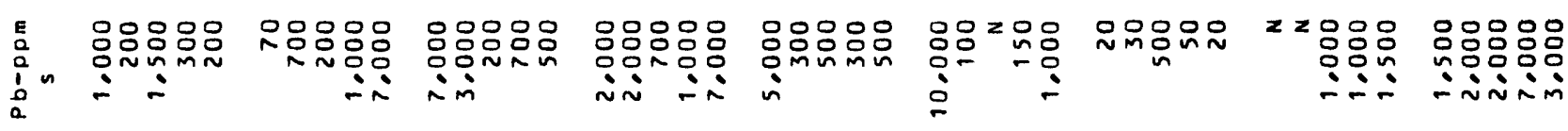

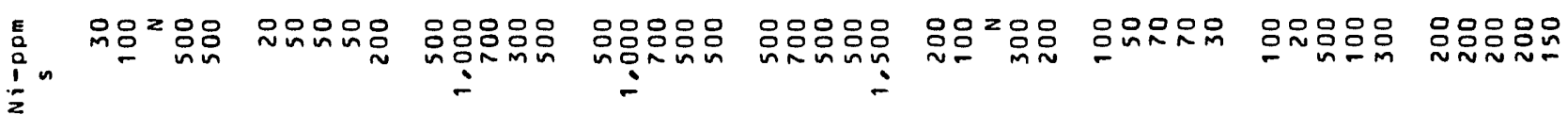

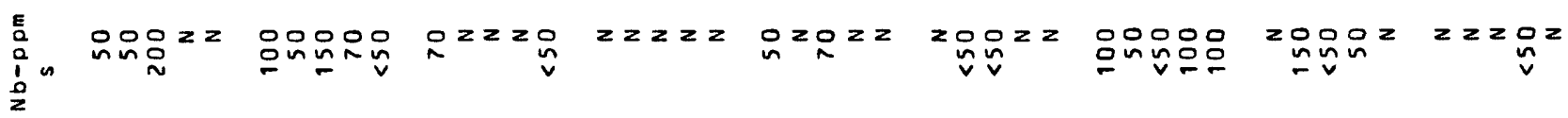

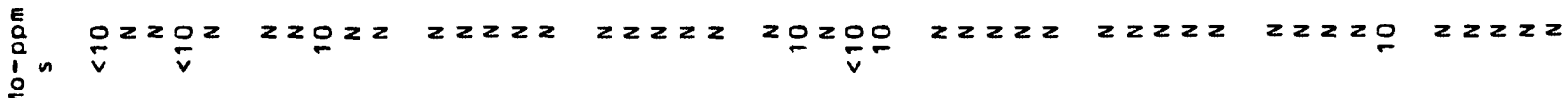

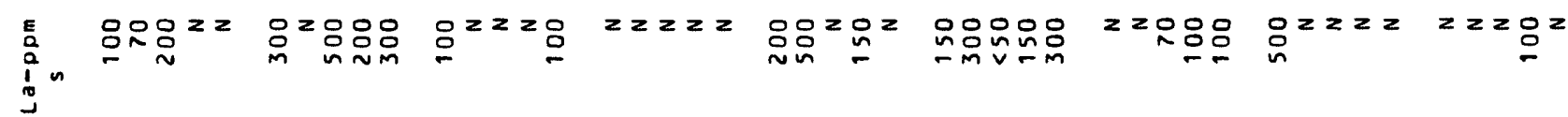

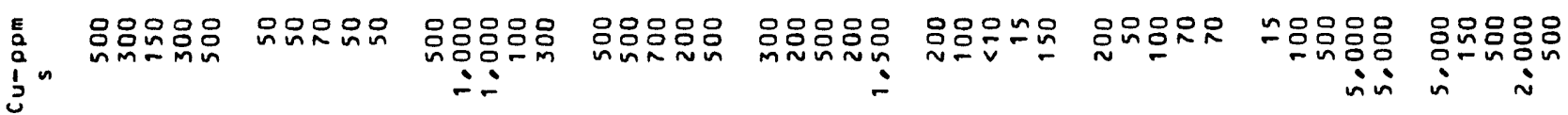

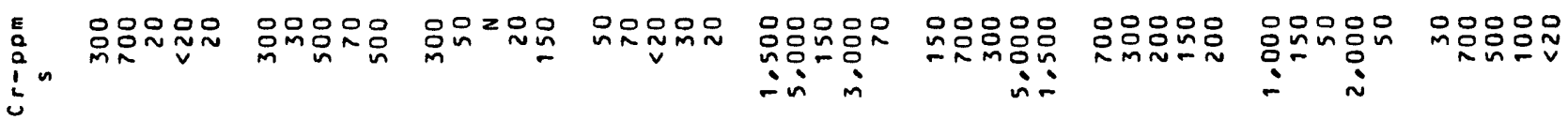

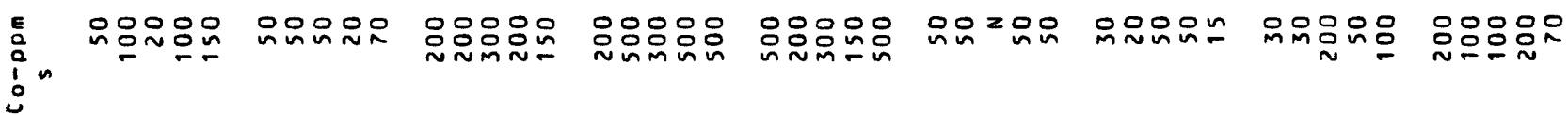

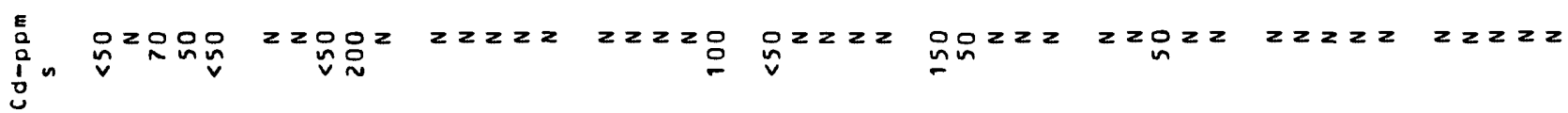

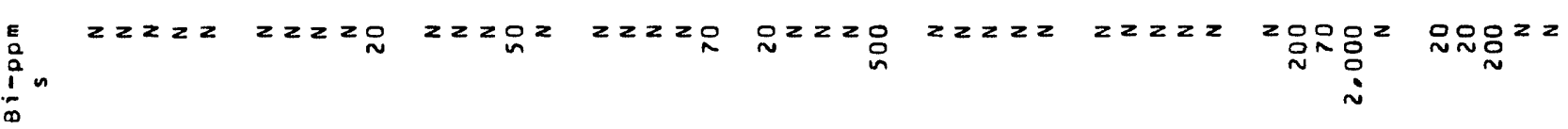

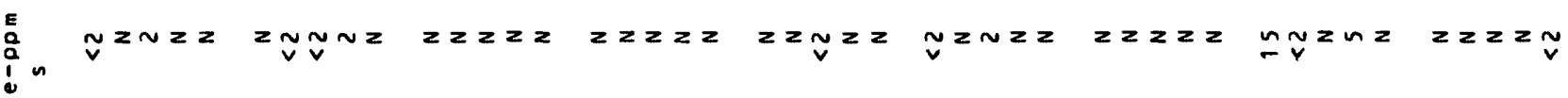

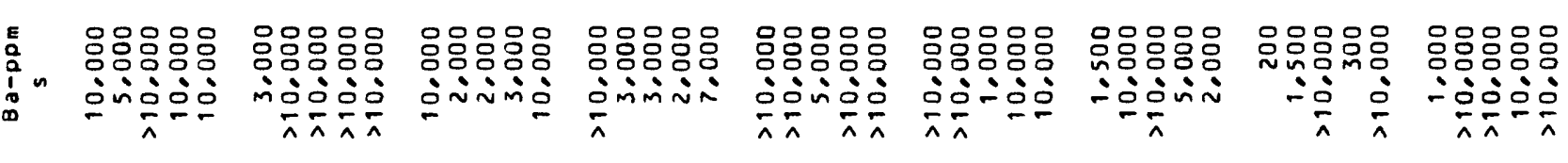

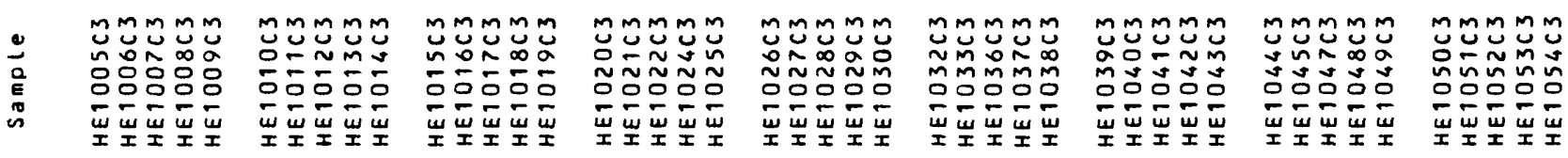




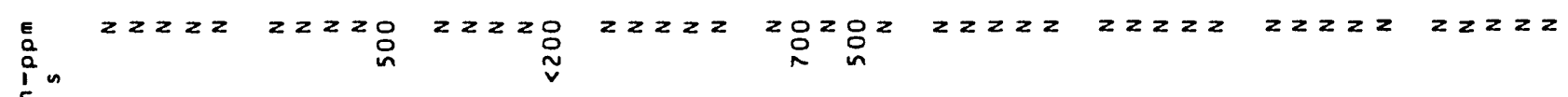

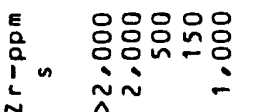

옹옹응응응

$\sim \sim \dot{\sim} \sim$

응응용용ㅇㅁㅇ

은응옹용ㅇㅇ

응옹옹용응

영ㅇㅇㅇㅇㅇㅇㅇㅇㅇㅁㅇ

응응용ㅇㅇㅇㅇㅇ

응응응응음

옹응응응요 $\dot{\sim} \sim \dot{\sim} \sim \dot{\wedge}$

iñ $\dot{\wedge}$

$\dot{\sim} \sim \dot{\sim}$

$\sim \dot{\sim} \sim$

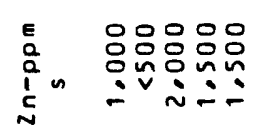

$z \circ 000$
inㅇㅇㅇ
m

응ㅇㅇㅇ음음음

응응ㅇㅇㅇㅇㅇㅁ
는

영응음은

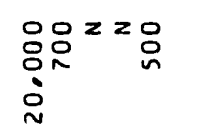

$2 z 0^{2 z}$
$\vdots$

$z=02$ 용

응 $z \geq z z$
ํ.

亭舟

음은은웃

응응응응응

은응ㅇㅁ음

온은으봉

음웅우

임요용

든으묻ㅇㅇㅇ

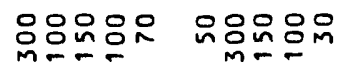

$E$
0
0
$\vdots$
3

$z=\frac{O}{v} z z=z \frac{O}{v}$

$\frac{0}{2}=2 z$

$\circ \geq 0$
$\frac{0}{v}$

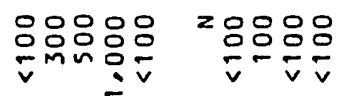

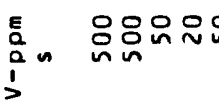

응응ㅇㅇ응

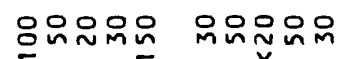

으음음운은

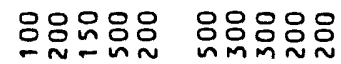

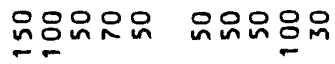

틍ㅇㅇㅇㅇㅇㅇㅇㅇ

$\circ 000$

응 $z=$ 응 응응 $z=z$

은ㅁํㄴ

nํำ:

n $m \stackrel{\sim}{\sim}$

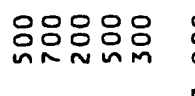

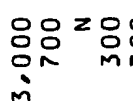

옹응은

응응응

응응응ㅇㅇ음

is

E⿱

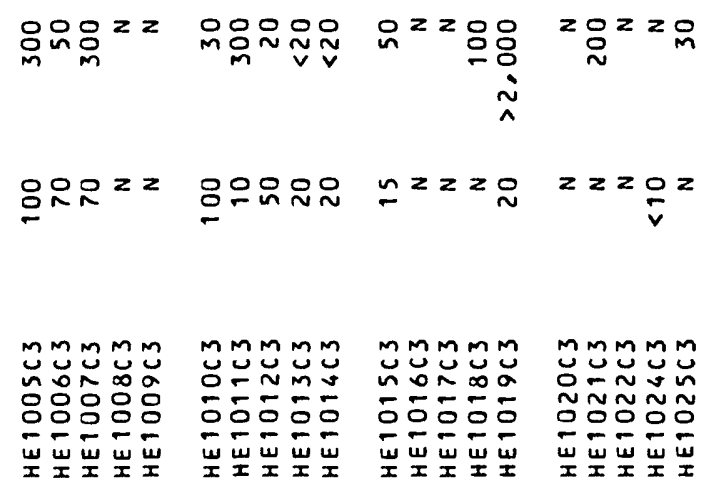

$z z z z$

일 $z=2$

$^{\circ} 0^{2}=0$

은

응ㅇㅇㅇㅇㅁㅇ
수

용으 $z=2$

운유으웃

응응음

옷으문은

옹운으은 z융ㅇㅇㅡ

\section{0
$E$
0
$n$}

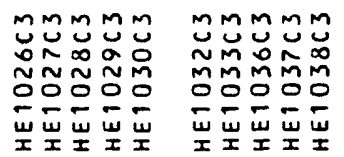

MMMmm

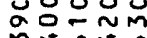

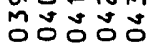

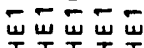

MmMmm UnNo O

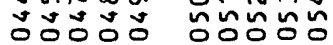

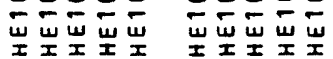




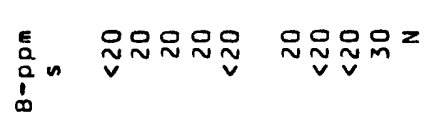

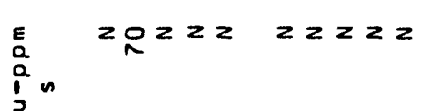

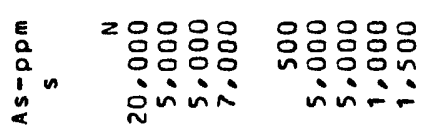

言

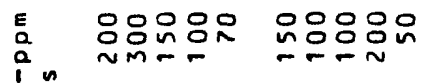

c. $^{\frac{1}{2}}{ }^{n}$

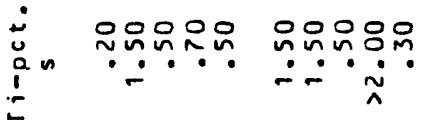

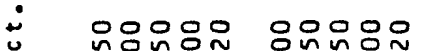

角

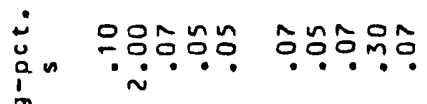

¿ 0000000000

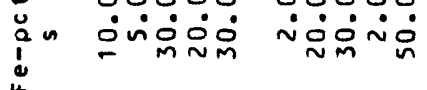

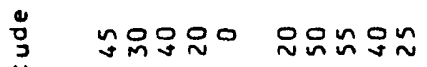

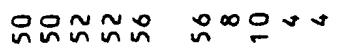

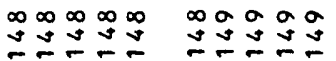

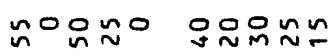
ONN $\infty$ a

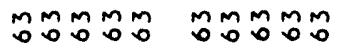

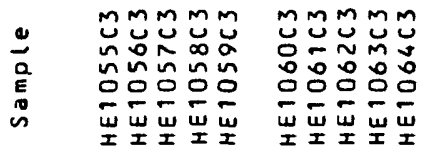




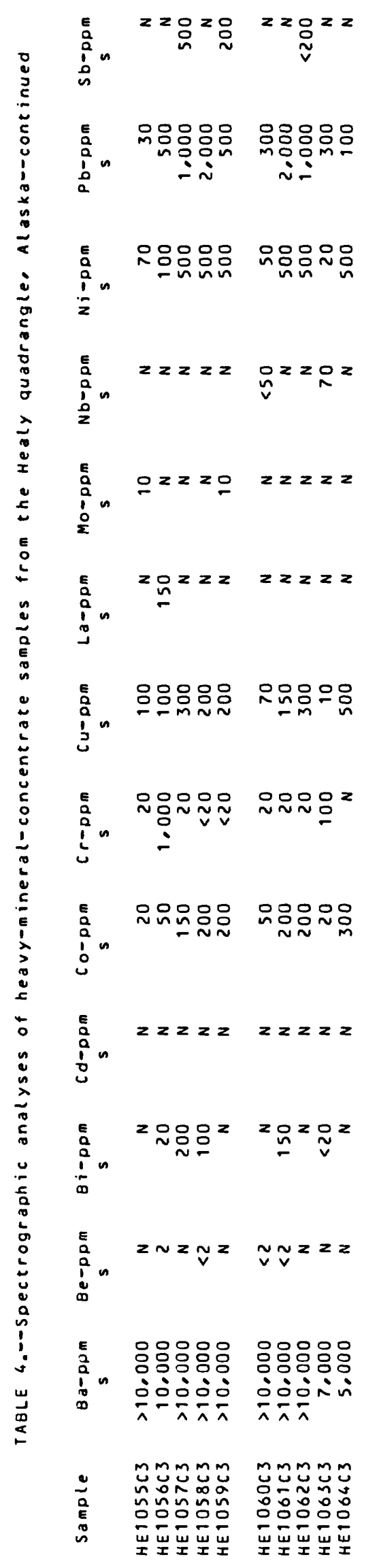




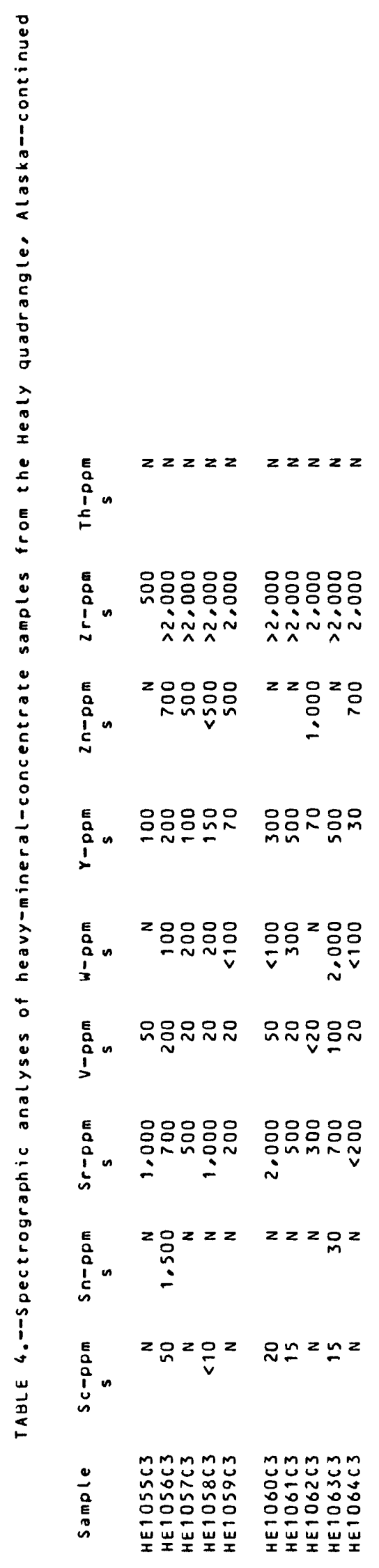

